\author{
UNIVERSIDADE DE SÃO PAULO \\ FACULDADE DE FILOSOFIA, LETRAS E CIÊNCIAS HUMANAS \\ DEPARTAMENTO DE LETRAS ORIENTAIS \\ PROGRAMA DE PÓS-GRADUAÇÃO EM LITERATURA E CULTURA RUSSA
}

FLAVIA CRISTINA MOINO CAROLINSKI

\title{
Aleksandr Nikoláevitch Afanássiev e o conto popular russo
}

São Paulo

2008 


\author{
UNIVERSIDADE DE SÃO PAULO \\ FACULDADE DE FILOSOFIA, LETRAS E CIÊNCIAS HUMANAS \\ DEPARTAMENTO DE LETRAS ORIENTAIS \\ PROGRAMA DE PÓS-GRADUAÇÃO EM LITERATURA E CULTURA RUSSA
}

\title{
Aleksandr Nikoláevitch Afanássiev e o conto popular russo
}

Flavia Cristina Moino Carolinski

Dissertação apresentada ao Programa de Pós-Graduação em Literatura e Cultura Russa do Departamento de Letras Orientais da Faculdade de Filosofia, Letras e Ciências Humanas da Universidade de São Paulo para obtenção do título de Mestre.

Orientadora: Profa. Dra. Arlete Orlando Cavaliere

São Paulo

2008 


\section{Agradecimentos}

À minha orientadora Profa. Dra. Arlete O. Cavaliere por sempre ter acreditado e incentivado meu trabalho.

Aos Profs. Drs. Bruno Barreto Gomide e Elena N. Vássina por toda a pronta atenção dispensada durante o processo do trabalho.

Aos Profs. Drs. Boris Schnaiderman e Serguei Nekliúdov pela generosidade com que me ajudaram a esclarecer diversos pontos da pesquisa.

À amiga e professora Tatiana Larkina pela paciência e permanente apoio.

A todos os meus amigos queridos que foram atormentados pelas minhas dúvidas eternas.

Ao meu superespecial marido que, com carinho e inteligência, acompanhou atentamente cada passo deste trabalho. 


\section{Resumo}

A coletânea Contos populares russos, lançada de 1855 a 1863 em oito volumes, foi resultado do cuidadoso trabalho de Aleksandr N. Afanássiev (1826-1871), responsável pela reunião e publicação de cerca de 600 textos presentes nessa obra, que ganhou destaque por ser a primeira coletânea de contos populares russos de caráter científico, tornando-se assim um importante material de estudo, além de apresentar a poesia e o humor inerentes aos contos.

Esta dissertação tem o objetivo de apresentar a trajetória desse pesquisador, que se dedicou não somente ao conto mas também a outras manifestações folclóricas, assim como traçar a evolução da presença do conto popular na vida literária e científica russa, fato que proporcionou o surgimento de diversos estudos folclorísticos, e apresentar alguns traços recorrentes do conto de magia. Para tanto, as pesquisas de Vladímir Propp, que muito se dedicou à cultura popular, em especial ao conto de magia, foram de extrema importância.

Esta dissertação apresenta ainda a tradução de onze contos de magia, cujo critério de seleção foi a presença das diferentes representações do personagem folclórico BabaIagá, e um breve estudo dos seus traços de acordo com as teorias proppianas.

Palavras-Chave:

Conto popular russo (skázka), conto de magia, folclore, folclorística, Rússia século XIX, Aleksandr N. Afanássiev, Propp, Baba-Iagá, bogatýr, piétch, bánia. 


\begin{abstract}
The collection Russian folktales, brought out from 1855 to 1863 in eight volumes, was the result of the careful work by Aleksandr N. Afanássiev (1826-1871), responsible for the gathering and publishing of around 600 texts in this work.

Afanássiev's work was the first Russian folktales collection with a scientific approach, it became a fundamental study material, besides presenting the tales inherent poetry and humour.

This dissertation has the objective to introduce Afanássiev's path, who devoted himself not only to the tale but also to other folklorist expressions, as well as to outline the evolution of the folktale presence in the literary and scientific Russian life, making possible the appearance of many folklorist studies.

Another purpose of this work is to present some recurring traits from the tales of magic. For this intention, Vladimir Propp's works, who dedicated a lot of his time to the popular culture, and in particular, to the tales of magic, were extremely important to us.

This dissertation also presents the translation into Portuguese of eleven tales of magic, in which the selection criteria was the presence of different representations of the folktale character Baba-Iagá, of which a short assessment is made of its traits, in accordance with Propp's theories.
\end{abstract}

Key Words

Russian folktale (skázka), tale of magic, folklore, folkloristic, Russian XIX century, Aleksandr N. Afanássiev, Propp, Baba-Iagá, bogatýr, piétch, bánia. 


\section{Sumário}

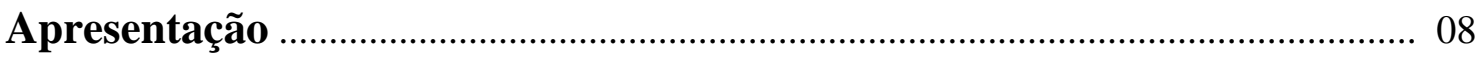

Sobre as edições de Contos populares russos .................................................... 13

\section{Parte I}

Capítulo I As primeiras manifestações literárias russas e o início do interesse pelo

folclore

O estudo científico do folclore

Capítulo II Aleksandr N. Afanássiev: vida e atividade científica 30

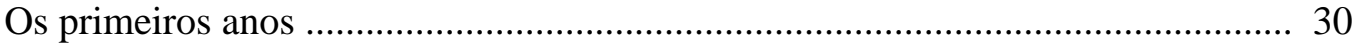

Da universidade à produção científica ................................................................... 33

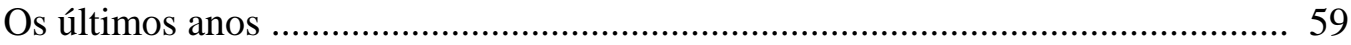

Capítulo III O conto popular russo (skázka) ................................................................. 63

Sobre a classificação ............................................................................................. 66

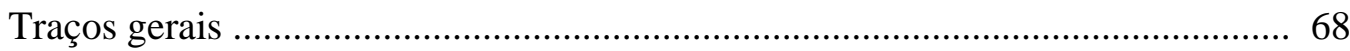

O estudo do conto de magia ............................................................................. 73

A imagem da Baba-Iagá e seu entorno ................................................................. 79

Outras observações sobre a Baba-Iagá............................................................... 84

\section{Parte II}

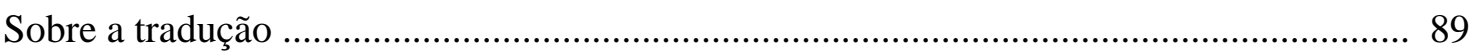

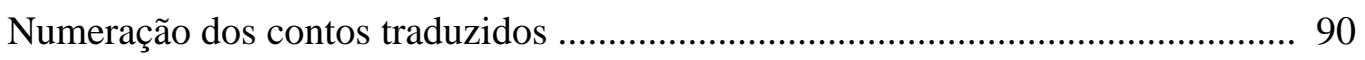

\section{Contos traduzidos}

1. A Baba-Iagá e o menino audacioso .................................................................... 93

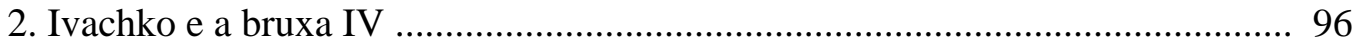

3. Os bogatyrí Medviédko, Ussýnia, Gorýnia e Dubýnia ..................................... 98

4. Ivan-tsarévitche e Biélyi Poliánin ................................................................. 105

5. Conto sobre o jovem valente, as maçãs da juventude e a água da vida II ........ 111

6. Conto sobre o jovem valente, as maçãs da juventude e a água da vida III ...... 115

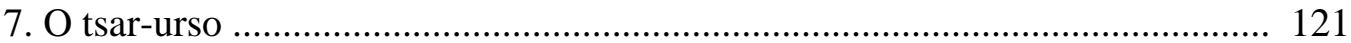

8. O leite de animal selvagem ....................................................................... 126 
9. A pena de Finíst, o falcão brilhante ............................................................... 133

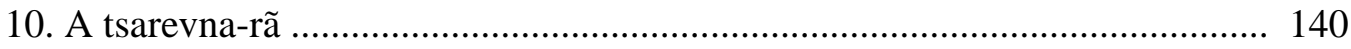

11. Vassilíssa, a bela ................................................................................. 144

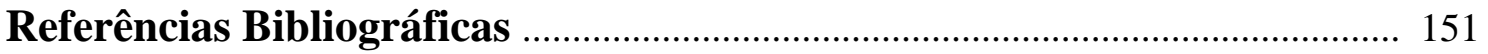

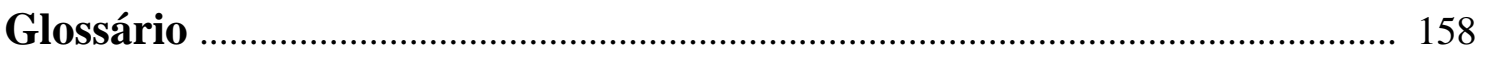

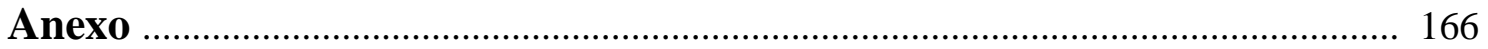




\section{Apresentação}

À noite eu escuto os contos e completo assim as lacunas de minha formação.

Que encanto são esses contos. Cada um é um poema.

Púchkin ${ }^{1}$.

Os contos populares russos (naródnye rússkie skázki) representam uma importante parte do variado e rico conjunto que conhecemos como arte popular russa, ou seja, do folclore russo.

As manifestações populares russas abrangem as mais diversas expressões artísticas nos mais diferentes períodos. Desse repertório, podemos citar as épicas bilinas com seus hercúleos bogatyrí (Ilya Múromiets, Aliocha Popóvitch e Dobrýnia Nikítitch); os contos populares; as lendas nas quais figuram Cristo e seus apóstolos; as canções históricas que contam episódios da vida de importantes personagens da história russa como Ivan, o Terrível, Boris Godunóv, Pugatchióv; as canções populares líricas das quais o amor, o casamento, a natureza, a vida cotidiana dos trabalhadores, camponeses e cossacos, o recrutamento militar são alguns dos temas; o teatro de marionetes com o conhecido personagem Petruchka; as charadas; os provérbios; as anedotas etc.

Um traço de destaque no universo da cultura popular é a oralidade. Contos, lendas, anedotas entre outros eram passados de geração para geração pelo boca a boca. Havia contadores que se especializavam em determinado gênero, tornando-se conhecidos pela sua maestria em expressar as histórias. Porém, um fator determinante para que essas manifestações sobrevivessem até os nossos dias foi o trabalho de importantes pesquisadores que se dispuseram a registrar e recolher esse tipo de material, imortalizando-o. Tal registro muito motivou o estudo das manifestações populares, a princípio condenadas principalmente pela Igreja que as via como exemplos de paganismo.

De forma geral, o interesse pelo material oral popular teve seu apogeu no século XIX. Um exemplo a ser ressaltado é o da publicação Contos da criança e do lar, dos irmãos Grimm, em 1812, na Alemanha. Na Rússia, esse interesse começou a ganhar

\footnotetext{
${ }^{1}$ Púchkin, A. S. apud Afanássiev, A. N. Prefácio ao primeiro volume da primeira edição, 1957, v. 3, p. 382.
} 
força com a busca por uma literatura nacional e com os trabalhos de Jukóvski, Púchkin e Gógol, que muito se inspiravam nas obras orais.

O primeiro estudioso a se dedicar à reunião e à publicação dos contos populares russos na sua forma mais autêntica e com propósito científico foi Aleksandr $\mathrm{N}$. Afanássiev (1826-1871). De 1855 a 1863, ele levou à sociedade russa leitora os oito volumes constituintes da sua obra Contos populares russos. Com isso, despertou o interesse de outros pesquisadores para que desenvolvessem realizações semelhantes, promovendo assim um intenso trabalho voltado para as produções populares que, por muito tempo, foram desprezadas pelas classes letradas.

Os Contos populares russos tomaram lugar entre as coletâneas de contos mais importantes da Europa do século XIX, servindo de material de estudo para o respeitado folclorista Vladímir Propp, que fundamentou seus trabalhos Morfologia do conto maravilhoso e Raízes históricas do conto maravilhoso em exemplos retirados dessa coletânea. Da mesma forma, até hoje não há estudo científico sobre o conto popular russo que não exemplifique suas teorias com contos de lá retirados.

A presente dissertação aborda, em sua primeira parte, a evolução da presença do conto popular na vida literária e científica russa, fato que proporcionou o surgimento de diversos estudos folclorísticos; a obra de inestimável valor e a personalidade científica de Aleksandr N. Afanássiev, cujo feito é de fundamental importância não só para o estudo do conto popular, mas para o das manifestações populares em geral; e algumas características do conto de magia e do personagem Baba-Iagá. A segunda parte deste trabalho dedica-se à tradução de onze contos de magia, pela primeira vez traduzidos diretamente do russo, tomando como base a sexta edição de Contos populares russos ${ }^{2}$, organizada por Vladímir Propp.

Com o crescimento do interesse pelo folclore e o surgimento de coletâneas científicas durante o século XIX, surgem diversas teorias folclorísticas que influenciaram o mundo e a Rússia. Assim, são descritas, de acordo com o seu aparecimento cronológico, algumas dessas escolas responsáveis pela análise dos textos poéticos populares, principalmente, a escola mitológica, desenvolvida pelos irmãos Grimm e introduzida na Rússia pelos trabalhos de Busláev e Afanássiev, da qual este último foi representante por toda a sua vida. O intuito no primeiro capítulo deste

\footnotetext{
${ }^{2}$ Afanássiev, A. N. Naródnye rússkie skázki. (Contos populares russos), 1957.
} 
trabalho é apresentar o que havia em termos de estudos folclorísticos na Rússia dessa época.

O segundo capítulo, ao se ocupar do pesquisador Aleksandr N. Afanássiev, procurou detalhar as informações sobre a sua carreira científica. Como já observado por seus biógrafos, as informações sobre a sua vida pessoal são muito escassas e sempre relacionadas à sua formação estudantil. Para retratar os seus primeiros anos de estudo até o ingresso à universidade, recorremos a citações das Memórias ${ }^{3}$ do próprio Afanássiev que, por sua força pictórica e expressiva - ao ponto de criar nítidas cenas da vida russa do início do século XIX - vão muito além da simples descrição dos eventos ocorridos durante sua infância e adolescência, adquirindo valor histórico. Para traçar o desenvolvimento intelectual de Afanássiev, seus primeiros artigos, seus interesses, sua afinidade pela escola mitológica, seus problemas com a censura, contamos com a ajuda de artigos originais em russo, assinados por importantes estudiosos como I. Sokolóv, V. Propp e a dupla de pesquisadores L. G. Barág e N. V. Nóvikov entre outros.

Sobre a coletânea Contos populares russos, reconhecida como um marco no estudo do folclore, tanto pela sua preocupação científica - pois até então as coletâneas eram explicitamente elaboradas ao gosto do público leitor - quanto pelo volume de material reunido, por volta de 600 contos, traçamos os passos do seu trabalho de publicação: como nasceu a idéia da sua concepção, o processo de reunião e seleção de contos, a repercussão do seu lançamento, a diversidade de opiniões com destaque para as do filólogo Pypin e do crítico Dobrolíubov, a influência dessas críticas sobre a concepção científica de Afanássiev, as polêmicas sobre o quanto Afanássiev teria alterado os originais etc. O enfoque fica sobre essa obra, porém todas as outras coleções realizadas por Afanássiev também são apresentadas: Lendas populares russas (1860), Concepções poéticas dos eslavos sobre a natureza (1866-1869), Contos populares russos infantis (1870) e Contos populares russos proibidos (1872).

O terceiro e último capítulo é reservado a uma apresentação do conto popular (skázka) e do personagem Baba-Iagá. Inicialmente, debruçamo-nos sobre questões gerais do conto popular (definição, classificação). Em seguida, voltamos nossa atenção especificamente ao estudo do conto de magia (volchiébnaia skázka). Ao lermos esses

\footnotetext{
${ }^{3}$ Escritas em 1855, as Memórias de A. N. Afanássiev foram publicadas pela primeira vez em 1872 (sobre a infância e os anos ginasiais) no periódico Arquivo Russo [Russkyi Arkhiv] e em 1886 (sobre os anos da faculdade) no Antiguidades russas [Russkaia Stariná]. Suas lembranças são conhecidas principalmente pelo detalhamento das descrições sobre os professores e o ambiente estudantil. O estudioso Iuri Sokolóv as considera um precioso documento sobre a história da Universidade de Moscou nos anos 1840.
} 
contos, torna-se evidente a presença de uma estrutura recorrente, com uma repetição de personagens, ações e seqüências. Com base no estudo das obras de V. Propp, que dedicou seus trabalhos à análise desse tipo de narração, apresentamos aspectos da forma e do conteúdo do conto de magia. No que diz respeito ao conteúdo, há uma ênfase nas origens históricas de alguns motivos em que se apresenta o personagem Baba-Iagá, relacionado, segundo Propp, ao personagem responsável (sacerdote) pelo rito de iniciação. A força simbólica dessa figura evoca uma série de questões passíveis de abordagem. Neste trabalho, apresentamos a classificação que a Baba-Iagá recebeu nos estudos de Propp (raptora, guerreira e doadora) e a opinião de outros estudiosos do assunto sobre questões relacionadas à origem do seu nome e à construção da sua imagem e do seu habitat: a isbá sobre pernas de galinha, localizada nos ermos da floresta.

A segunda parte destina-se, como já mencionado, à tradução. A seleção de contos teve como objetivo realizar uma breve amostra dos diferentes tipos de Baba-Iagá de acordo com a classificação proppiana. Assim, dos onze contos populares de magia, dois são sobre a Baba-Iagá raptora; dois, sobre a guerreira e outros sete sobre a doadora. No conjunto da obra de Afanássiev, podemos afirmar que, na grande maioria dos contos, a Iagá apresenta-se como doadora. No papel de raptora, divide seu posto com a tradicional bruxa dos contos populares. Já os contos em que ela se apresenta como guerreira são extremamente raros.

Como doadora, apresentamos, na maior parte, contos em que o herói é masculino. Nessa função, a Iagá relaciona-se com o herói de uma maneira muito bem definida, enquanto com a heroína muitas vezes essa relação é variada. Geralmente, a heroína chega até a Iagá enviada por sua madrasta, presta-lhe serviços, auxiliada por ajudantes ou objetos mágicos, e só assim obtém algo da criatura. Os contos “A pena de Finíst, o falcão brilhante” (235) e "Vassilíssa, a bela” (104) são exemplos dessa variação. O primeiro mostra uma situação rara: uma heroína no papel geralmente desempenhado por um herói, isto é, em busca do noivo; e o segundo ilustra exatamente a clássica cena da relação entre uma heroína e a Iagá. Embora seja considerado um conto retrabalhado, "Vassilíssa, a bela” é um forte representante da imagem estereotipada da Baba-Iagá e de todo o seu entorno, isto é, sua isbá, seus apetrechos, seu transporte etc.

\footnotetext{
${ }^{4}$ Os números entre parênteses indicam o número do conto no original russo, utilizado em edições e estudos acadêmicos. Ver p. 90.
} 
A tradução desses contos pôde dar uma pequena dimensão do tão peculiar e atraente personagem Baba-Iagá, muito conhecido entre os russos de todas as idades. Dentre o diverso elenco de personagens do conto popular, ela sempre teve uma posição especial: do simples leitor, criança ou adulto, aos cientistas do folclore, todos ficam fascinados por essa enigmática criatura. $\mathrm{O}$ aterrorizante personagem rapidamente passa a fazer parte da memória dos seus ouvintes/leitores.

As mudanças que lhe ocorreram chamam muito a atenção. De sua possível origem histórica na figura de um grande e respeitável sacerdote tribal, tornou-se um personagem grotesco e até mesmo cômico no conto, uma bruxa má, dominada por crianças. Com o passar do tempo, a Baba-Iagá amansou-se, transformando-se numa simpática velhinha, o que talvez denigra um pouco demais a sua imagem, principalmente, para aqueles que se apaixonaram pela sua caracterização monstruosa, decrépita, ou até mesmo para aqueles que vêem no papel negativo da bruxa um fator positivo.

Vale lembrar ainda que os apetrechos da Iagá também passaram por modificações. Em versões modernas, sua isbá não só gira como também anda e até mesmo corre, e a vassoura passou a ser uma nova opção de transporte, além do pilão. As mais diversas situações produzidas pela imaginação podem servir de cenário para a atuação da BabaIagá.

Finalmente, é importante ressaltar que o folclore continua sendo um tema muito presente na cultura russa, tendo até hoje um papel fundamental tanto como criação quanto como objeto de estudo. Se a cultura camponesa já não é mais tão intensa, o folclore passou a florescer na cidade, criando canções, lendas, contos com personagens presentes em fábricas, universidades, grupos sociais e políticos...

Neste trabalho encontram-se ainda um glossário e um anexo, resultantes da profunda pesquisa motivada pela tradução que permitiu reunir diversas informações sobre tópicos específicos da cultura russa que podem esclarecer dúvidas ou saciar a curiosidade do leitor. 


\section{Sobre as edições de Contos populares russos}

De todas as coletâneas realizadas por Aleksandr N. Afanássiev, a mais divulgada e traduzida é Contos populares russos. Na Rússia, ela recebeu diversas edições, vejamos algumas delas:

A primeira edição foi lançada em oito volumes que saíram ao longo de oito anos (1855-1863). Os dois primeiros volumes tiveram três reedições, o terceiro e o quarto, duas $^{5}$. Os contos eram publicados à medida que chegavam às mãos de Afanássiev e, por isso, não dispunham de uma classificação sistematizada.

A segunda edição (póstuma), preparada pelo próprio autor, saiu em 1873, em quatro volumes, e serviu de base para todas as edições posteriores. Para ela, Afanássiev criou um sistema de divisão de contos (contos de animais, de magia-fantásticos, de costumes ou novelísticos), a essas categorias principais ele adicionou ainda contos com enredos de bilinas, anedotas etc. ${ }^{6}$ Muito importante: nessa edição, cada conto recebeu um título e um número. Se o conto tivesse variantes, elas viriam em seqüência, no corpo do texto, e com uma enumeração (em números e letras) que indicasse serem variantes. Ex: 1a, 1b, 1c etc.

A terceira edição, lançada em dois volumes em 1897, foi preparada pelo literato, folclorista, pedagogo e a partir de então biógrafo de Afanássiev, A. E. Gruzínski. O texto e a distribuição dos contos não tiveram alterações. Os comentários foram dispostos no fim de cada conto e não mais no volume final da edição. Para essa edição, Gruzínski escreveu a primeira biografia detalhada de Afanássiev, utilizando diários inéditos, memórias e correspondências. A edição recebeu ainda um índice onomástico e de temas.

A quarta edição saiu em cinco volumes (1913-1914) e também foi organizada por Gruzínski. Da anterior, ela se diferenciou em algumas correções biográficas, na ampliação do índice de temas e na introdução de uma lista bibliográfica de diversas edições de contos russos e estrangeiros.

A quinta edição, lançada em três volumes (1936-1940), surgiu na época socialista. Foi preparada pelos importantes estudiosos do folclore M. K. Azadovski, N. P.

\footnotetext{
${ }^{5}$ Isso segundo Propp e Sokolóv. Porém em seus comentários, Barág e Nóvikov dão a seguinte informação: o primeiro, segundo e terceiro volumes tiveram três reedições, e o quarto, duas.

${ }^{6}$ Propp, V. I. Comentários in Afanássiev, A. N. Contos populares russos, v.1, 1957, p. 463.
} 
Andréiev e I. M. Sokolóv, este último escreveu um artigo sobre a vida e as atividades científicas de Afanássiev, considerado um dos melhores no assunto.

A partir do cotejo com manuscritos preservados na Sociedade Russa de Geografia, essa edição recuperou algumas alterações e cortes feitos pela censura. Além disso, houve também correções ortográficas e a abertura de novos parágrafos.

Ainda na quinta edição, os contos receberam uma nova numeração, em vez da indicação de variantes por número e letra, elas foram introduzidas na seqüência normal de contos, ou seja, de 1a, 1b, 1c passaram para 1, 2, 3. Os contos que faziam anteriormente parte dos comentários de Afanássiev e eram de fonte oral foram colocados nessa mesma seqüência, já os de fonte escrita foram dispostos no final de cada volume na seção Anexos. Os comentários de Afanássiev foram substituídos pelos de Andréiev. Nessa edição, nas partes finais do terceiro volume publicaram-se 33 textos da coleção Contos populares russos proibidos.

A sexta edição, em três volumes, lançada em 1957, foi preparada e prefaciada por V. I. Propp e manteve os princípios de preparação da quinta, sendo ainda eliminados erros de impressão e outras imperfeições que escaparam à revisão anterior. Os Contos populares russos proibidos não fizeram parte dessa edição.

A principal diferença ocorreu na atualização dos contos para a ortografia moderna e na correção das palavras que eram grafadas segundo a pronúncia; as palavras regionais ganharam um dicionário no fim de cada volume.

Outra modificação: os contos de origem literária, colocados anteriormente nos Anexos do fim de cada volume, são reunidos no final do terceiro volume e numerados de acordo com a seqüência dos contos. Os comentários de Andréiev e a lista bibliográfica foram suprimidos e, em seu lugar, introduzido um índice de tipos ${ }^{7}$, preparado por Andréiev, com a classificação dos contos russos, assim como suas variantes em outras coletâneas de contos russos. Além disso, utilizando a obra Anotações sobre os contos infantis e do lar dos irmãos Grimm, de I. Bolte e G. Polivka $^{8}$, Andréiev indica variantes do conto russo entre os contos de diversos países.

Além dos índices onomástico e de temas, foi introduzido também um topográfico.

\footnotetext{
${ }^{7}$ Em 1929, N. P. Andréiev foi convidado pela Sociedade Russa de Geografia a traduzir o célebre The types of the folktale, realizado em 1910 por Antti-Aarne. Além de traduzir, Andréiev o completaria com as variantes das coleções de contos russos, assim, esse índice ficou conhecido como AA (AarneAndréiev).

${ }^{8}$ Nessa obra, os autores deram a cada conto da coletânea dos irmãos Grimm as suas variantes recolhidas em obras de diversos países.
} 
A sétima edição, em três volumes, 1984-1985, foi preparada pelos pesquisadores L. G. Barág e N. V. Nóvikov. Manteve a mesma seqüência numérica utilizada a partir da quinta. Nos Comentários há a localização, caso exista, do manuscrito na Sociedade Russa de Geografia. Em seus Anexos foram introduzidos contos cortados pela censura, a introdução e alguns contos da coleção Contos populares russos proibidos e ainda contos pertencentes ao, até então, manuscrito, Contos populares russos não publicáveis 1857-1862. As notas de rodapé de Afanássiev a algumas palavras ou expressões estão na íntegra nessa edição e, quando necessário, os organizadores deram esclarecimentos adicionais.

O índice de tipos utilizado não é mais o AA e sim o AT, as classificações entretanto mantiveram-se praticamente iguais, uma vez que o AA se baseou no índice de Aarne. Porém, para os casos em que o tipo não se encontra no AT, foi utilizada a classificação do Índice comparativo de tipos: Conto popular do leste eslavo (Sravnítelnyi ukazátel siujiétov: Vostotchnoslaviánskaia skázka - SUS).

Todas essas edições destacaram-se pelo seu caráter científico e por serem especificamente direcionadas a estudiosos. Novas edições que apresentassem a coletânea completa de Contos populares russos foram lançadas, mas sem tanto detalhamento acadêmico. Seus contos, direcionadas ao público em geral, podem ser encontrados de maneira adaptada ou não e agrupados sob os mais diversos critérios: os mais conhecidos, para as crianças, com personagens recorrentes, contos populares do mundo etc.

Porém, ao contrário das coletâneas de contos alemães, em que dificilmente os nomes dos irmãos Grimm não são lembrados, os contos russos são divulgados na maior parte das vezes em traduções que não fazem menção ao nome do seu organizador ou, se a fazem, não a destacam. E mesmo na sua terra natal, Afanássiev é lembrado com alguma dificuldade por seus conterrâneos. Seria muito apropriado se houvesse uma associação direta, como no caso dos contos alemães ou franceses, entre a coletânea e o seu organizador. Assim, ao se falar em contos populares russos automaticamente deveríamos lembrar de Afanássiev e de toda a sua exaustiva dedicação em valorizar a arte popular, tornando-a perene. 


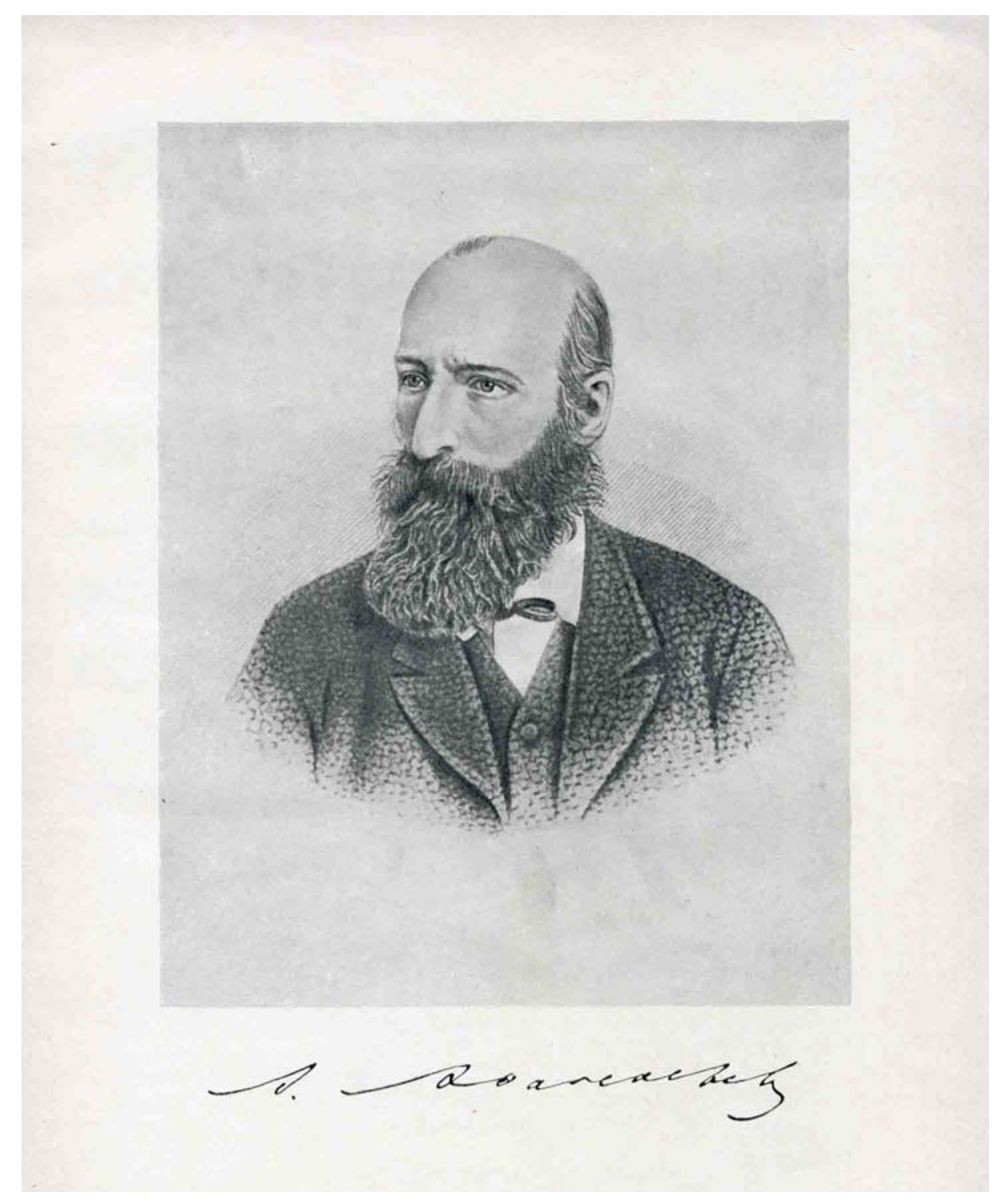

Aleksandr N. Afanássiev ${ }^{9}$

${ }^{9}$ Afanássiev, A. N. in . Naródnye rússkie skázki (Contos populares russos),1984, v.1, p. 3. 
PARTE I 


\title{
As primeiras manifestações literárias russas e o início do interesse pelo folclore
}

\author{
... infelizmente não temos literatura antiga. Atrás de nós há uma estepe escura, \\ e nela viceja apenas um monumento: A campanha de Igor. \\ Púchkin ${ }^{1}$ \\ O menor som de uma canção me diz mais sobre o passado do que as nossas crônicas. \\ Gógol $^{2}$
}

O início da literatura russa é marcado pela conversão do Estado de Kíev ao cristianismo em 988. Do século $X$ ao século XVII, o que se tinha era predominantemente uma literatura religiosa e com objetivos edificantes. A partir do século XI, conhecido pela quantidade de documentos escritos ${ }^{3}$, obtêm-se na Rússia as primeiras informações sobre o seu desenvolvimento cultural. Entretanto, é preciso lembrar que, bem antes dos primeiros documentos literários, as obras populares já há muito existiam (provérbios, contos, canções etc.), mas dessas manifestações não se têm registros nem estudos nacionais especializados até o século XIX. Composta em eslavo eclesiástico $^{4}$, a literatura escrita religiosa (sermões, vida de santos, crônicas, manuais de boa conduta), via com hostilidade as tradições populares, consideradas ricas em paganismo. Porém, curiosamente, os poucos relatos folclóricos existentes partem desse material religioso ao exemplificar o que deveria ser combatido. Para os representantes da Igreja, entre os pecados que certamente levariam ao inferno estavam a crença em mau-olhado, em adivinhações, nas profecias dos pássaros e no ato de narrar contos e tocar gúsli ${ }^{5}$.

Com o objetivo de registrar os acontecimentos da época, surgiram as crônicas (liétopis), realizadas tanto por religiosos quanto por laicos alfabetizados. Relatando fatos históricos ano a ano, reuniam eventos reais aos conhecidos por meio de lendas e

\footnotetext{
${ }^{1}$ Púchkin, A.S. apud Wolff, T. (org.) Pushkin on literature, 1986.

${ }^{2}$ Gógol, N. Carta a Srezniévski (1834) apud Gruel-Apert, L. La tradition orale russe, 1995, p. 26.

${ }^{3}$ Serman, I. De la littérature orale à la littérature écrite in Etkind, Efim ; Nivat, Georges et alli (org.). Histoire de la littérature russe, 1992, t. 1, p. 13.

${ }^{4} \mathrm{O}$ eslavo eclesiástico limitou-se aos meios religiosos e políticos, bem distante do povo que se expressava por uma linguagem bastante coloquial.

${ }^{5}$ Gúsli - antigo instrumento musical de cordas dedilhadas. Colocado sobre o colo do instrumentista, é tocado com as duas mãos. Lembra a cítara.
} 
cantos épicos populares, ou seja, misturavam fontes históricas e populares ${ }^{6}$. Uma das mais conhecidas é a Crônica dos tempos passados (Póvest Vriémennykh liét), ou, como ficou popularmente conhecida, Crônica de Nestor ${ }^{7}$, considerada uma das mais importantes referências sobre a história da Rússia antiga, serve de fonte de informação àqueles que pesquisam os tão escassos dados históricos de tal época. As crônicas ainda fazem menção sobre a existência de cantores populares (skomorókhi ${ }^{8}$ ) pertencentes aos reinos, embora, de modo geral, eles e seus repertórios fossem perseguidos pela Igreja.

Entre os materiais que representam a literatura antiga pode-se citar o célebre $O$ dito da expedição de Igor (Slóvo o polku o Ígoreve), obra de cunho épico que, em linguagem literária, eslavo eclesiástico, embora com motivos populares, narra um fato da antiguidade histórica: a infeliz expedição militar comandada pelo príncipe Igor Sviatoslávitch, de Nóvgorod-Seviérski, em 1185, com o objetivo de expulsar os polovetsianos, um povo nômade que se estabeleceu nas estepes da Rússia, prejudicando as relações comerciais com o Oriente. Tido como uma obra-prima da literatura antiga, o canto já gerou muita polêmica principalmente no que se refere à sua autenticidade ${ }^{9}$.

Entre os séculos XIII e XV (1240-1480), com o solo russo sob jugo mongol, não se tem conhecimento de grandes manifestações literárias, apenas de alguns relatos de guerra tanto de tom realista quanto lendário, sermões e vidas de santos; entretanto, constata-se um forte florescimento da arte pictórica religiosa nos ícones de Andrei Rubliov (c. 1360-1430) ${ }^{10}$. No século XV, Moscou se consolida como centro político e

\footnotetext{
${ }^{6}$ Sokolóv, I. Le folklore russe, 1945, p. 18.

${ }^{7}$ Nome do monge a quem é atribuída a autoria da obra.

${ }^{8}$ Na Rússia antiga, skomorókhi eram artistas populares itinerantes que reuniam diversas habilidades: cantavam, dançavam, tocavam instrumentos musicais, atuavam em números acrobáticos e cômicos.

${ }^{9}$ Essa obra vem a conhecimento público somente em 1788, quando o conde Musin-Púchkin a compra de um monge. O que o conde havia adquirido era um manuscrito do século XVI, já supostamente cópia de um original atribuído ao século XII. Do manuscrito, com a ajuda de especialistas, em 1800, o conde publicou uma edição que apresentava a versão em russo antigo e a tradução para o moderno. Pelo caráter peculiar da obra, muitos estudiosos, dentre os quais o francês André Mazon, afirmavam que não se tratava de um documento construído no século XII, mas sim de uma falsificação como outras que ocorriam na época. Entre os que defendiam a legitimidade da obra estava um grupo liderado por Roman Jakobson que, ao rebater todas as críticas apontadas por Mazon, identificou traços comprovantes da autenticidade da obra, idéia aceita até os dias de hoje. (A gesta do príncipe Igor. Trad., introd. e notas de Carlos Santos Pereira. Lisboa, Cotovia, 1992, p. XI e ss.)

${ }^{10}$ O domínio tártaro da Horda de Ouro dura cerca de 300 anos. Seu declínio começa em 1380 com a derrota para o príncipe Dmitri Donskoi, na batalha de Kulikovo, anexando as cidades de Suzdal e Vladímir a Moscou. Desde então esses invasores vão perdendo forças até serem totalmente eliminados. Muitos historiadores defendem a data de 1480 como o fim do domínio mongol. Entretanto, vale lembrar que as fronteiras russas ainda eram indefinidas e frágeis, longe do mapa que conhecemos atualmente. Assim, provavelmente, 1480 deve ser a data do fim do jugo mongol na região de Moscou e proximidades, considerando que as terras a leste, como Kazan, liberta em 1552 por Ivan, o Terrível, ainda estavam sob o jugo mongol.
} 
capital predestinada a se tornar a terceira Roma ${ }^{11}$. Durante essa época, a produção literária circulava em torno de textos relacionados à política, história, relatos de viagem e ainda muitos escritos religiosos. Porém, após a morte de Ivan, o Terrível, em 1584, inicia-se um crítico período político conhecido como o Tempo das Inquietações que vai até 1613, data em que foi eleito, Mikhail Románov, o primeiro tsar da dinastia Románov. Desse momento até a ascensão de Pedro, o Grande, tem-se um período de transição, em que se destaca o cisma religioso de $1667^{12}$; a obra autobiográfica, Vida, de um dos opositores da reforma, o arcipreste Avvakun, ganha grande destaque como obra literária.

No que se refere às obras populares, pode-se afirmar que a sua reunião e publicação deram os seus primeiros fracos passos no século XVII com os trabalhos de dois ingleses: Richard James, que organizou a primeira coleção de cantos históricos a partir da sua estadia em Arkangel, em 1619 e 1620, e Samuel Collins, que tomou nota de narrações sobre o reinado de Ivan, o Terrível, durante a sua permanência em Moscou, onde viveu de 1660 a 1669. Ainda no mesmo século, os russos começaram a recolher algumas bilinas (canções épicas), mas isso era feito por pura curiosidade, de maneira diletante, e, portanto, esses textos recebiam todo tipo de modificação tanto rítmica quanto semântica; sendo trabalhados de acordo com a língua escrita, sua divulgação ocorria entre a pequena nobreza, os comerciantes, os funcionários públicos, o baixo clero e camponeses instruídos.

Com o governo de Pedro, o Grande (1689-1725), no século XVIII, formou-se uma literatura que se espelhava na produção literária ocidental, sobretudo, no classicismo francês e na sua aversão ao popular. Tal processo de ocidentalização iniciado por Pedro se manteve por todo o século XVIII, fortalecendo a separação entre a classe dominante, voltada para os costumes franceses, para uma literatura imitativa, e o povo que continuava independentemente sua produção poética. De forma bastante superficial, no fim do mesmo século, nota-se, porém, um interesse por obras populares livremente adaptadas.

\footnotetext{
${ }^{11}$ Constantinopla é tomada pelos turcos em 1453. Assim, a Rússia passa a ser o único centro ortodoxo livre da dominação islâmica. Esse fato, unido à expulsão dos tártaros, estimulou a crença de que Moscou seria a escolhida divinamente para ser a sucessora de Bizâncio.

12 O cisma eclodiu quando o patriarca Nikon resolveu retirar de circulação e queimar todos os livros litúrgicos que continham erros ocasionados por copistas ou tradutores incultos, afastando os textos dos originais gregos, e propor modificações no ritual da Igreja. Os que apoiavam as medidas tinham o apoio do governo e da Igreja, enquanto os opositores, chamados de antigos crentes (staroviéry), foram perseguidos.
} 
Assim, o folclore começa a ganhar simpatizantes entre as classes superiores ainda que estivesse muito longe de suas reais raízes. Os apreciadores da literatura clássica viam as manifestações orais como algo inferior, um produto do populacho. A aristocracia se divertia com apresentações pseudopopulares em que servos interpretavam sobretudo romances e canções galantes traduzidas do francês e do alemão ou ainda canções populares nacionais modificadas para "ne pas choquer l'oreille délicate des dames ${ }^{13}$ ".

De 1780 a 1783, M. D. Tchulkóv publica uma coleção de contos russos em dez volumes. Essa obra, entretanto, era formada por contos populares completamente estilizados ao gosto do público leitor, que muito apreciava romances de cavalaria e aventuras maravilhosas. Havia ainda vários escritores imitadores, que criavam obras inspiradas no folclore nacional ou estrangeiro, e tradutores, que modificavam as obras originais com o intuito de russificá-las. De literatura clássica a romances de cavalaria e contos populares, muitas dessas obras eram publicadas no formato de literatura de lubók ${ }^{14}$. Esse era o padrão de disseminação das obras populares durante o século XVIII.

É somente a partir do século XIX que o interesse pelas obras populares na Rússia se intensifica realmente. Influenciada por teorias liberais ocidentais, a Rússia do início do século XIX é palco da revolta dezembrista ${ }^{15}$ (1825), de discussões sobre a emancipação da servidão (1861), de uma intelectualidade que expressa seu interesse pelo povo e sua busca por uma identidade nacional. Embora sob um governo com tsares autocratas e de forte censura, surge um período de intensa expressividade intelectual, literária, política etc. Todo esse novo cenário foi muito propício à geração de interesse por materiais folclóricos e ao desenvolvimento do seu estudo científico.

Surge então um grande anseio por uma literatura nacional pondo um fim à forte influência da literatura francesa, distante da realidade russa. Em busca disso, recorre-se às obras poéticas populares, tidas como o que havia de mais representativo do

\footnotetext{
13 “não chocar os ouvidos delicados das damas". Sokolóv, op. cit., p. 20.

${ }^{14}$ No original lubótchnaia literatura. Presentes na Rússia durante a segunda metade do século XVIII até início do século XX, eram edições populares e baratas. Nas suas páginas encontravam-se contos adaptados, bilinas, romances de cavalaria, vida dos santos, narrativas históricas, mas também adaptações de obras clássicas européias ou coletâneas de anedotas e canções. Guardam semelhanças com a literatura de cordel. A palavra lubótchnaia vem de lubók, que, por sua vez, tem origem na palavra lub, isto é, a entrecasca da tília. Com essa entrecasca, faziam-se tábuas de madeira onde eram gravadas sobretudo imagens, mas também textos; a esses quadros, assim como às estampas produzidas por ele, dá-se o nome de lubók.

${ }^{15}$ A revolta ocorre em 14 de dezembro de 1825. Após a morte de Alexandre I, um grupo de oficiais pertencentes à nobreza, influenciado por idéias liberais, opôs-se à sucessão do impopular Nicolau I ao mesmo tempo que reivindicou mudanças no regime tsarista como a implantação de uma Constituição. A revolta foi fortemente reprimida e seus participantes, presos e mortos ou exilados.
} 
verdadeiro espírito russo, da verdadeira nacionalidade tão almejada. A produção popular era fruto do espírito criativo dos camponeses, dessa forma, difunde-se uma idéia que se tornou típica do século XIX, cujos anos 60 ficaram conhecidos como os anos de ouro do folclore russo, a idéia de “ir até o povo”, ou seja, de se ter no contato direto o encontro com as raízes nacionais esquecidas sob a influência francesa.

O início do século XIX caracteriza-se ainda pelas obras criadas a partir da imitação ou adaptação da poética popular, mas, com a crescente intensificação da busca da nacionalidade, surgem as primeiras coletâneas com o objetivo de serem verdadeiramente científicas e seus processos de coleta e publicação. Em 1804 surge a primeira coletânea de bilinas Velhos poemas russos, publicada por Kircha Danílov, de quem a história somente manteve o nome. Nas primeiras décadas do século XIX, contos e lendas populares foram disseminados e ganharam destaque social na pena de autores que se inspiraram no folclore ao compor suas obras, dentre os quais Jukóvsksi ${ }^{16}$, Púchkin e Gógol.

Baseando-se em suas memórias dos contos que ouvia de sua ama, mas também no contato direto que teve com o popular, sobretudo, durante o seu exílio em Mikháilovskoe, quando reuniu canções populares (que seriam mais tarde passadas para Piotr Kiriéevski) e escutou e resumiu contos da região ${ }^{17}$, Púchkin criou contos versificados inspirados em motivos e personagens típicos dos contos populares. Os contos versificados de Púchkin gravaram-se de tal maneira na memória do povo que muitos motivos originalmente folclóricos são lembrados muito mais a partir dos seus versos do que de uma coletânea dedicada ao assunto. Ele conseguiu fornecer ao conto uma tão esperada e autêntica coloração nacional que foi sentida por todos os falantes da língua $^{18}$, introduzindo com fineza a cultura oral popular nos meios literários. As obras de Púchkin estavam longe das rudezas e do erotismo presentes nos contos populares reunidos posteriormente nas coletâneas de Afanássiev.

Nesse período, o folclore é também objeto de oposições políticas. A partir dos anos 1830, surgem na Rússia dois importantes movimentos socioideológicos: o ocidentalismo e o eslavofilismo. Entre os primeiros estudiosos do folclore, estavam muitos partidários dessas duas correntes e, assim, as pesquisas folclóricas acabavam

\footnotetext{
${ }^{16}$ Para alguns estudiosos como Paulo Chostakowsky (História da literatura russa), Jukóvski, embora desenvolvesse em sua obra temas no estilo popular russo, carecia, na verdade, do espírito popular.

${ }^{17}$ Altschuller, M. e Dryzhakova, E. Littérature et folklore en Russie au cours de la première moitié du XIX siècle in Efim Etkind; Georges Nivat et alli (org.), Histoire de la littérature russe, 1992, t. 2, p. 1018.

${ }^{18}$ Ibidem.
} 
sendo influenciadas pela posição política do pesquisador. Entre os eslavófilos, citam-se, P. Kiriéevski, que recolheu na década de 1830 obras da poesia popular, sobretudo, canções, as quais, por diversas questões (inclusive a censura), somente seriam publicadas a partir de 1860; Vladímir Dal reunidor de contos, lendas e provérbios, cuja publicação também teve inicialmente problemas com a censura e I. M. Sneguirióv autor de uma coletânea de provérbios (1834) e de uma obra sobre festas e ritos populares (1837).

Cada corrente procurava no folclore indícios que comprovassem suas convicções. Conservadores, os eslavófilos idealizavam a velha Rússia, acreditando que a história do país poderia se desenvolver sem seguir os mesmos passos do Ocidente. Para esse grupo a essência da cultura russa era religiosa, as formas tradicionais de vida e os velhos costumes expressavam a verdadeira essência da Rússia e por isso deveriam ser conservados. Viam no folclore a representação dos bons velhos tempos, do bom povo, admirador do tsar, dos senhores e dos popes. Assim, os eslavófilos ansiavam por materiais folclóricos que demonstrassem a inerente submissão do povo aos seus governantes.

Por sua vez, entre os ocidentalistas havia aqueles que, numa postura claramente contrária aos eslavófilos, preferiam desprezar o folclore, e outros como Belínski (18111848) que o enxergavam longe da idealização eslavófila. Para Belínski, a tradição oral revelava um povo rico em clareza de espírito e bom senso (nos seus provérbios), aspirante pela liberdade (canções cossacas), provido de desprezo pelas classes dominantes e clero (contos e provérbios) ${ }^{19}$.

As mesmas idéias eram compartilhadas por Herzen (1812-1870) que se baseava nos contos e canções populares para declarar que, entre os principais traços do povo russo, estavam a sua indiferença à religião e a aspiração pela liberdade.

Nota-se que ambas as posições, eslavófila ou ocidentalista, apresentavam um ponto em comum: a busca, cada uma ao seu modo, por aspectos nacionalistas na produção popular.

Mais tarde, os adeptos da democracia revolucionária, como Tchernychiévski (1828-1889) e Dobroliúbov (1836-1861) também expressariam suas posições sobre o folclore. Principalmente sobre a necessidade de adicionar ao seu estudo a descrição da

\footnotetext{
${ }^{19}$ Gruel-Apert, L. op. cit., p. 37.
} 
realidade social dos camponeses, idéia que teve suas primeiras menções feitas por Belínski.

\title{
O estudo científico do folclore
}

\begin{abstract}
Não cito as escolas meteorológica, filológica, antropológica, histórica, ritualista, a infalível eclética, afora uma dúzia de cisões e cismas eruditos. Ainda não me foi concedida a sabedoria para aproximar-me dessas discussões substanciais. Um dia, querendo Deus, irei também discutir se o Jabuti representa o Sol, a força criadora da Vontade, um urmythus ou simplesmente um Jabuti. Cascudo $^{20}$
\end{abstract}

O interesse científico pelas manifestações populares consolida-se no século XIX, muito pela influência das idéias do romantismo caracterizadas pelo nacionalismo, pela busca da alma nacional, das raízes. O estudo das raízes nacionais direcionou para as obras orais a atenção de diversas áreas do saber, como, filosofia, história, lingüística.

Nesse movimento, surgem destacados pesquisadores, sobretudo ingleses e alemães que, por meio de um estudo comparado das línguas, perceberiam um ancestral comum, sua origem indo-européia.

Na Alemanha, os cientistas de maior destaque - e que influenciaram muitos outros em todo o mundo - foram os irmãos Wilhelm (1786-1859) e Jacob Grimm (1785-1863). Eles se dedicaram ao estudo do material oral nacional, sobretudo Jacob Grimm que, sozinho ou em parceria com o irmão, produziu dicionários, gramáticas e histórias da língua alemã, textos sobre a mitologia alemã, antiguidades do direito alemão e a famosa coletânea de contos populares. Assim, pesquisaram detalhadamente tanto textos antigos quanto a língua corrente, entrando em contato com uma grande variedade de material de origem popular: contos, provérbios, lendas, ritos e costumes. E dessa maneira, conseguiram apresentar a riqueza do passado alemão em diversas áreas, o que estava em total concordância com as expectativas das teorias românticas.

Os irmãos Grimm passaram a ser conhecidos também como os fundadores da escola mitológica, que muito se utilizou do método comparativo lingüístico aplicado ao estudo da poesia popular (contos, lendas, canções etc). O surgimento e desenvolvimento dessa escola estavam fortemente ligados ao desenvolvimento dos estudos lingüísticos da época. Por meio do estudo comparativo das línguas dos povos da Europa e da Índia,

\footnotetext{
${ }^{20}$ Cascudo, L. da C. Prefácio in Contos tradicionais do Brasil, 2003, p. 17.
} 
observaram-se semelhanças que indicavam a existência de um ancestral comum, a língua indo-européia, o que explicava as semelhanças entre as línguas eslavas, germânicas, itálicas etc. Essa teoria seria levada para os estudos folclorísticos ao se verificar a semelhança das narrações dos povos da família indo-européia. Os representantes da escola mitológica supunham que, na época da unidade indo-européia, os contos não existiam, mas sim os mitos sobre divindades. Entre suas tarefas, a escola mitológica tinha o objetivo de reconstruir, a partir das narrativas populares, as representações religiosas da antiguidade, a sua mitologia.

Todo o trajeto de pesquisas e idéias dos irmãos Grimm recebeu muitos admiradores, a escola mitológica teve seguidores em todo o mundo. Dentre eles podemse citar Kuhn, Schwartz e Mannhardt, na Alemanha; Max Müller, na Inglaterra; e Busláev, Afanássiev e Oreste Miller, na Rússia. É interessante notar que a maior parte dos estudiosos dos mitos e manifestações populares era formada por filólogos, o que mostra como o estudo da língua estava extremamente vinculado ao do mito.

Cada um desses pesquisadores, à sua maneira, desenvolveu os conceitos da escola mitológica, criando as mais diversas ramificações de um mesmo tema. Sem nunca abandonar o método comparativo, as novas correntes traziam, com muitas semelhanças entre si, outras interpretações sobre o surgimento e desenvolvimento dos mitos e das narrativas populares. Assim, temos Kuhn e Schwartz na escola meteorológica, que via a criação dos mitos como resultado da divinização das forças da natureza. As narrativas míticas simbolizavam a luta entre essas forças, sobretudo, dos fenômenos pluviais.

Max Müller e sua teoria solar, por meio da qual explica a origem dos mitos mais uma vez a partir da divinização dos fenômenos naturais, mas, ao contrário da escola meteorológica, dessa vez os fenômenos estavam relacionados ao astro sol.

Nos trabalhos dos adeptos dessas vertentes era comum encontrar interpretações onde a luta entre o herói e o dragão era tida como a luta entre a nuvem negra (dragão) e o sol (herói), que com sua espada (relâmpago) destruía e cortava a nuvem negra.

Outro estudioso da época era Wilhelm Mannhardt (1831-1880) que, embora tenha seguido inicialmente os passos de seus antecessores, observou as falhas presentes no método mitológico e nas suas variações, atendo-se mais ao estudo das crenças populares contemporâneas do que à reconstituição dos antigos mitos.

Na Rússia, entre 1850 e 1860, a escola mitológica teve grande repercussão como um eficaz método de estudo lingüístico e da poesia popular - crenças, tradições, mitos, contos, canções etc. - sendo considerada a escola iniciadora dos estudos folclóricos 
russos. O primeiro a fazer uso das teorias dessa escola na Rússia foi F. I. Busláev, seguido por Afanássiev que se manteve, ao contrário do seu antecessor, fiel às análises da escola mitológica até o fim de sua vida. Busláev, ao perceber a série de exageros à qual tal corrente facilmente levava, acabaria abandonando-a e se direcionando à teoria dos empréstimos.

Assim, como os irmãos Grimm, Busláev dedicou-se ao estudo da língua e da ligação desta com o pensamento, a poesia, a mitologia. Assim, expressava-se:

Les débuts de la création poétique se perdent dans les pronfondeurs obscures de la préhistoire, lorsque se construit la langue elle-même, et la naissance de la langue constitue le premier essai de l'esprit créateur, essai décisif et brillant. Le mot n'est pas un signe conventionnel destiné à exprimer une idée, mais une forme artistique provoquée par la vive sensation que produisent sur l'homme la nature et la vie. L'imagination populaire créatrice passe directement de la langue à la poesie. La religion est la force dominante qui donne à cette imagination l'impulsion la plus décisive, et les ancies mythes, avec les rites qui les acompagnent, jouent un grand rôle dans la création de la langue et la poésie, celle-ci embrassant tous les intérêts moraux du peuple ${ }^{21}$.

Outro adepto da escola mitológica foi Afanássiev que, embora tivesse uma formação na área jurídica, dedicou-se intensamente ao estudo da antiguidade russa por meio de diversas manifestações populares: mitos, lendas, contos, costumes, tradições etc. Ardoroso adepto da escola mitológica, o que na opinião de muitos críticos resultou em comentários bastante viciosos, Afanássiev aplicou tanto os seus conceitos quanto os das teorias derivadas dessa escola: meteorológica e solar. Assim, via nos mitos eslavos e indo-europeus a representação de tempestades, nuvens, a batalha entre a luz e as trevas. Além disso, como partidário da escola mitológica considerava a origem do mito a partir da formação da língua:

La parole humaine vivante, avec ses expressions métaphoriques et harmonieuses, est la source abondante, et pour ainsi dire unique, des diverses représentations mythiques. Pour montrer la façon nécessaire et

\footnotetext{
21 "Os primórdios da criação poética se perdem nas profundezas obscuras da pré-história, quando a língua se constrói, e o nascimento da língua constitui a primeira tentativa do espírito criador, tentativa decisiva e brilhante. A palavra não é um signo convencional destinado a expressar uma idéia, mas sim uma forma artística provocada pela viva sensação que a vida e a natureza produzem sobre o homem. A imaginação popular criadora passa diretamente da língua à poesia. A religião é a força dominante que dá a essa imaginação o mais decisivo impulso, e os antigos mitos, com os ritos que os acompanham, têm um importante papel na criação da língua e da poesia, a qual abrange todos os interesses morais de um povo." Buslaev, F. Estudos históricos sobre a literatura e a arte populares russas, 1861 apud Sokolóv, I. in op. cit., p. 32.
} 
nautrelle dont se forment les mythes, les fables, il faut recourir à l'histoire du langage. [...] Par suite de cette dégradation séculaire de la langue, de la transformation des sens et du renouvellement des conceptions qu'expriment les mots, le sens primordial des anciennes expressions devient de plus en plus obscur et énigmatique, c'est alors que commence le processus des généralisations mythiques. ${ }^{22}$

E naturalmente, Afanássiev não dispensava o método comparativo nas suas pesquisas :

On comprend donc pourquoi il est indispensable d'étudier comparativement les traditions populaires, les supertitions et autres vestiges du passé... La méthode comparative donne le moyen de reconstituer la forme primitive des traditions, et ainsi confère une solidité particulière aux conclusions du savant en lui permettant de les vérifier ${ }^{23}$.

Ao ter como base de análise a própria língua, por meio do método comparativo, os métodos científicos da escola mitológica eram vistos pelos seus seguidores como um grande avanço rumo a um estudo objetivo.

Voilà porquoi la nouvelle méthode d'explication des mythes mérite confiance, elle entreprend son oeuvre sans avoir formulé d'avance des conclusions et chacune de ses thèses se fonde sur les témoignages directs du langage: dûment compris, ces témoignages sont solides comme un monument authentique et inébranlable du passé ${ }^{24}$.

Entretanto, uma das críticas que esse mesmo método recebia era o subjetivismo dos seus adeptos nas análises, fato que levaria os trabalhos teóricos de Afanássiev, reunidos em Concepções poéticas dos eslavos sobre a natureza ${ }^{25}$ (1866-1869), ao obsoletismo posterior. No entanto, sua obra é respeitada até hoje pela abordagem

\footnotetext{
22 “A palavra humana viva, com suas expressões metafóricas e harmoniosas, é a fonte abundante e, por assim dizer, única das diversas representações míticas. Para demonstrar a maneira necessária e natural como se formam os mitos, as fábulas, é preciso recorrer à história da linguagem [...]. Como conseqüência da degradação secular da língua, da transformação dos sentidos e da renovação das concepções que as palavras expressam, o sentido primordial das expressões antigas torna-se cada vez mais obscuro e enigmático, é nesse momento então que começa o processo das generalizações míticas.”Afanássiev apud Sokolóv, op. cit. p. 35.

${ }^{23 ، “ C}$ Compreende-se portanto porque é indispensável estudar comparativamente as tradições populares, as superstições e outros vestígios do passado... O método comparativo fornece o meio de reconstituir a forma primitiva das tradições, conferindo assim uma particular solidez às conclusões do cientista, permitindo-lhe dessa maneira averiguá-las.” Ibidem.

24 "Eis o porquê do novo método de explicação dos mitos merecer confiança: ele apreende sua obra sem ter antecipadamente formulado conclusões, e cada uma de suas teses fundamenta-se em testemunhos diretos da linguagem: devidamente compreendidos, esses testemunhos são sólidos como um monumento autêntico e inabalável do passado.” Idem, p. 36.

${ }^{25}$ Em edições atuais, essa obra passou a se chamar Mitologia da Rússia antiga. (Concepções poéticas dos eslavos sobre a natureza), assim apresentada nas referências bibliográficas deste trabalho.
} 
pioneira de muitos temas e pela intensa pesquisa de material envolvida, passando a ser consultada não só por estudiosos do assunto, mas também por escritores e poetas. Como exemplo de exagero no uso de seu método, o pesquisador Iuri Sokolóv aponta uma interpretação de Afanássiev para a clássica cena da Baba-Iagá que pretende matar o herói Ivan, o qual, por sua vez, consegue fugir, enganando-a e fazendo-a entrar no forno. Segundo Afanássiev, reconhecem-se nesses personagens a nuvem que tenta destruir o raio solar e como ele triunfa a dissipando com o seu calor ${ }^{26}$.

É preciso citar ainda um terceiro representante da escola mitológica russa, Oreste Miller, que a aplicou de maneira rigorosa no estudo das bilinas em Ilia Múromets e os bogatyrí de Kiev. Embora tenha recebido muitas críticas até mesmo dos próprios colegas da escola, esse trabalho foi a primeira tentativa de análise filológica da bilinas.

Contemporânea a Afanássiev, na década de 1860, no interior de movimentos ocidentais que se distanciavam do romantismo, surge uma outra importante corrente folclorística a teoria orientalista ou dos empréstimos ${ }^{27}$. Fundamentada pelo alemão Theodor Benfey, em 1859, com a edição dos contos indianos do Pantchatantra (Os cinco livros), a teoria orientalista apontava a intensa semelhança entre as narrativas populares da Índia e as do Ocidente. Dessa forma, surgiu uma nova maneira de se explicar as semelhanças entre mitos, contos, lendas etc. que não fosse a partir da origem comum dos povos, como fazia a mitologia comparada, adepta da origem indo-européia. As semelhanças eram agora explicadas pela influência da migração das obras orientais para o Ocidente, o que teria ocorrido por meio de relações históricas e culturais, como campanhas militares, o comércio, as conquistas árabes, as Cruzadas. Um dos objetivos dessa corrente era traçar a rota dos motivos presentes nos contos, lendas etc. ${ }^{28} \mathrm{Na}$ Rússia, os seus adeptos de maior destaque foram A. Vesselóvski, que considerava a teoria dos empréstimos propícia à análise histórica e, portanto, realista da literatura popular, Busláev e Vsiévolod Miller, que já se direcionava para uma outra escola folclorística russa, a escola histórica.

Após a teoria dos empréstimos, outras teorias influenciaram os cientistas russos, como a escola antropológica (Tylor e Lang) e a finlandesa. Muitos deles pertenciam inicialmente a uma escola e conforme tomavam conhecimento das novas teorias,

\footnotetext{
${ }^{26}$ Sokolóv, op. cit. p. 36.

${ }^{27}$ Entre outros nomes era chamada também de indianista ou de teoria das migrações.

${ }^{28}$ Sokolóv, I. op. cit. pp. 39-40.
} 
vinculavam-se a essas novas tendências ou as adaptavam. Assim como Busláev e Vsiévolod Miller, Vesselóvski passou a se basear em uma outra escola, em específico, na antropológica ${ }^{29}$.

Na trajetória da folclorística russa, uma outra escola de destaque foi a escola histórica que surge na Rússia no fim do século XIX e segue pelas primeiras décadas do século XX. Fundada por Vsiévolod Miller, seus seguidores tinham como objetivo procurar a base histórica da poesia popular, esforçando-se para fundamentá-la a partir da história nacional. Esclareciam onde e quando tinha se formado determinada obra oral poética e que eventos históricos estavam na sua base. Entre seus representantes estavam A. V. Márkov e Boris e Iuri Sokolóv.

O avanço dos estudos folclorísticos russos seguiu com grande sucesso pelo século XX, com o surgimento de muitas publicações especializadas no assunto e a criação de cátedras de folclore nas universidades, responsáveis pela coleta de novos materiais. Propp, Jakobson, Meletínski, Lotman são apenas alguns dos nomes mais conhecidos pertencentes às teorias dedicadas ao folclore que se desenvolveram no decorrer do século passado como o formalismo com seus estudos sincrônicos e diacrônicos.

Neste trabalho, julgamos necessário apresentar apenas as escolas contemporâneas a Afanássiev, principalmente, aquela à qual ele aderiu, a escola mitológica.

\footnotetext{
${ }^{29}$ Meletínski, E. A poética do mito, 1987, p. 142.
} 
Aleksandr N. Afanássiev: vida e atividade científica

\begin{abstract}
Os contos populares russos, de A. N. Afanássiev, são interessantes não somente como imagens artísticas do folclore camponês dos meados do século XIX [...]. O próprio fato da edição desses contos é notável pelo seu valor histórico e serve como um marco na história das opiniões sociais e das pesquisas científicas. Esse fato revelou que na sociedade russa da metade do século passado [XIX] ocorreram grandes mudanças, que provocaram o interesse pela arte popular.
\end{abstract}

Sokolóv ${ }^{1}$.

\title{
Os primeiros anos
}

O nome de Aleksandr Nikoláevitch Afanássiev, nascido em 1826, na cidade de Bogutchár, Vorónej, ao sul de Moscou, acumula títulos: historiador, historiador da literatura, crítico literário, teórico do folclore, jornalista.

As informações biográficas de Afanássiev, sobre a infância, adolescência e primeiros anos na universidade, são baseadas em suas Memórias $^{2}$. Nessa obra, ele concentra-se numa detalhada descrição das instituições de ensino que freqüentou e seus professores. Muito pouco é dito sobre a sua vida pessoal, a não ser em fatos relacionados à sua formação educacional. Por exemplo, ao citar a existência de uma rica biblioteca em sua casa, onde passava horas a fio da sua infância, ao falar sobre a variedade de periódicos e livros lidos por seu pai ou ainda o desejo do mesmo em dar uma educação completa para todos os seus filhos.

Os trechos mais pertinentes estão relacionados ao detalhamento com que descrevia seus professores, o que revela os métodos educacionais e opiniões da época. Assim, na sua infância tornaram-se conhecidos os popes Ivans, cujas condutas são tidas como responsáveis pelo posterior desprezo ao meio clerical e seminarista de Afanássiev:

\footnotetext{
${ }^{1}$ Sokolóv, I. Vida e atividade científica de A. N. Afanássiev in Afanássiev, A. N. Contos populares russos, 1936, p. IX.

${ }^{2}$ Ver Apresentação deste trabalho, nota 3, p. 10.
} 
Nossos mestres, os popes Ivans, eram pessoas sem conhecimento, rudes por natureza. Um deles era um grande beberrão e freqüentemente batia em sua mulher, enquanto o outro Ivan era manipulado pela sua mulher, que também gostava de beber e batia em seu marido. Essas cenas e também as cenas da ganância com que os popes tratavam os paroquianos (mujiques dos arredores), certamente, não poderiam servir como um exemplo benéfico para nós. ${ }^{3}$

Ainda sobre eles, dizia:

Pelo nosso despreparo e travessuras, éramos castigados, colocavam-nos de joelhos, batiam-nos com paliami, isto é, com réguas nas mãos, deixavamnos sem almoço, puxavam-nos pelos cabelos e orelhas, mas não permitiam que nossos pais nos açoitassem. Como complemento a esses edificantes castigos, o primeiro pope Ivan adicionava ainda o seguinte: ele obrigava um aluno a bater em outro, que não soubesse a lição, com bofetadas; e eu me lembro como às vezes as garotas eram conduzidas a dar bofetadas nos meninos e vice-versa. Semelhante a isso, o outro pope Ivan obrigava dois meninos culpados de algo a se pegarem pelas orelhas ou cabelos e, com grande satisfação, apreciava quando eles, irritados pela dor, com uma certa raiva reprimida, tentavam puxar um ao outro. O mesmo sábio mestre obrigava o culpado a voltar para casa com o casaco ou o gorro pelo avesso ou o obrigava como punição a se deitar nu no chão perto da soleira da porta, fazendo com que qualquer um que tivesse de passar de um cômodo para o outro tranquilamente pulasse por cima dele. Lembro-me também que o primeiro pope Ivan arranjou umas tabelinhas com os nossos nomes onde, no decorrer da semana, anotava nossos sucessos, quem recebia: scit, nescit, mediocriter. Aos sábados, acontecia sempre a represália, independentemente de já termos sido punidos pelo desconhecimento da aula anterior. Nesse dia, todos os alunos eram colocados de joelhos, fosse qual fosse a nota que tivessem; o professor pegava a tabelinha com uma mão e, com a outra, a régua e, por ordem, dirigia-se a nós: quem tinha em todos os lugares scit estava liberado para sentar, quem tinha nescit recebia uma boa palmatoada por cada nota dessa. Assim terminava a represália, e éramos liberados para ir para casa; neste dia não havia aulas depois do almoço. $^{4}$

Em 1837, Afanássiev entra em um colégio ginasial em Vorónej. O problemático meio educacional não muda muito e, em suas Memórias, há diversas histórias sobre episódios de ignorância, grosseria, crueldade, bajulação, hipocrisia, carolice, corrupção e bebedeira que reinavam no meio docente. O método de ensino baseado na memorização de textos pouco compreensíveis, os castigos físicos, os constantes insultos ao amor-próprio da criança, eis o que Afanássiev menciona quando caracteriza a educação nessa época:

\footnotetext{
${ }^{3}$ Afanássiev, A. N. Memórias apud Sokolóv, op. cit., p. XI.

${ }^{4}$ Idem, p. XII.
} 
As aulas de língua e literatura russa (nas últimas séries) eram dadas por $\mathrm{N}$. M. S...ov.

... S-v era um hipócrita no sentido pleno da palavra. [...] tinha uma fisionomia carola e puritana, a cabeça um pouco inclinada para o lado, os olhos frequentemente elevados para o céu; entrava na classe modesta e silenciosamente. Os alunos levantavam-se e começavam a orar. Geralmente era preciso ler as orações conhecidas antes e depois de cada aula... mas S-v nunca se contentava apenas com uma oração, os meninos podiam ler quantas e quais orações quisessem, por todo o tempo, ele permanecia em pé e orava com uma humildade devota. Nós sabíamos disso e, para encurtar o tempo das aulas, geralmente continuávamos a proferir todas as orações que conhecíamos e, dessa forma, às vezes roubávamos meia hora de aula...

S-v praticamente nos proibia de ler os livros da biblioteca do ginásio, embora, nós o importunássemos pedindo isso, e, na aula, ele não nos apresentava os escritores russos, à exceção de Muravióv e Jukóvski. Púchkin era chamado por ele de ateu, julgava seus romances uma heresia. Os temas das redações de S-v eram geralmente as quatro estações do ano, as quatro idades da vida, as vantagens da educação etc. As redações com certeza eram da pior qualidade possível, as frases eram justapostas sem nenhuma coerência, mas nós sabíamos como agradar o devoto mestre. Era necessário realizar somente uma simples técnica e, independentemente de quanto ruim era a redação, recebíamos a nota máxima. A técnica era simples: ao descrever um passeio, era preciso que o autor da redação a terminasse ouvindo o som de um sino chamando para a missa matutina ou vespertina e entrando no templo divino para agradecer ao provedor por tão prazeroso passeio e por todas as belezas da natureza por ele criada; ao descrever uma tempestade, era preciso terminar a redação com uma oração a deus, que se manifestava nas terríveis nuvens negras e nos relâmpagos que enchiam de chuva os campos de seu rebanho. E nós glorificávamos essas preces [...] em quase todas as redações, com ou sem um propósito esse era um subterfúgio que dava bons resultados.

Apesar de tal exagerada devoção, S-v nem sempre estava livre de ataques de ira e irritação, eu me lembro que uma vez ele correu com raiva atrás de um aluno pela classe para bater nele, lembro-me como bateu no rosto de um outro aluno, que, tendo ouvido o ensino dos evangelhos do mestre, ofereceu-lhe a outra face, e S-v furioso e fora de si com tamanho insulto violentamente bateu-lhe várias vezes na outra face e o deixou de joelhos $[\ldots]$

S-v constantemente procurava manter-se perto do bispo Antônio, esperando dele grandiosas e ricas dádivas, e parece que não foi em vão. Ele escrevinhou em péssimos versos um elogio ao santo Mitrofan e forçou cada um de nós a comprar essa obra poética por um rublo de prata. ${ }^{5}$,

Ao obter um conhecimento tão claro da precariedade educacional, os estudiosos de Afanássiev apontam seu destaque posterior como resultado da sua própria curiosidade, do seu desejo de saber e persistência pessoal.

\footnotetext{
${ }^{5}$ Idem, p. XIV.
} 


\section{Da universidade à produção científica}

... nela [na universidade] como num reservatório geral confluíam forças jovens de toda a Rússia, de todas as camadas sociais; em suas salas, eles se purificavam de seus preconceitos, adquiridos junto da lareira doméstica, nivelaram-se, irmanavamse entre si e novamente espalhavam-se por todos os lados da Rússia, em todas as suas camadas.

Herzen $^{6}$

Em 1844, Afanássiev com dificuldade ingressa na Universidade de Moscou, no curso de Direito. Curiosamente, um dos mais renomados representantes da língua e literatura popular estava numa área distinta de seu campo de atuação posterior. Considerando a reputação de suas anteriores instituições de ensino, tal momento é visto como uma verdadeira vitória de Afanássiev em sua contínua batalha pela busca de uma sólida formação. Esse seria um momento de ruptura na vida do jovem interiorano, que assim se expressou sobre essa primeira fase: "Rapidamente me acostumei com Moscou e com ardor juvenil me envolvi com a universidade. Para mim nessa época tudo estava ligado à vida universitária, ela preenchia toda a minha vida. ${ }^{7 \text {, }}$

A Universidade de Moscou na época era o centro de discussões filosóficas de toda a Rússia. O momento político do período universitário de Afanássiev era extremamente agitado. Ele se encontrava em pleno século XIX, o século da Rússia pré-revolucionária, tomada pela efervescência política e intelectual. A universidade era palco de discussões, professores e alunos eram adeptos de diferentes correntes ideológicas, dividindo-se em eslavófilos e ocidentalistas. Nessa época, havia na universidade um grupo de professores que tinha se formado no estrangeiro e que trazia novos métodos e teorias científicas da Europa para a Rússia ${ }^{8}$. Esses anos encarregaram-se de construir as convicções democráticas de Afanássiev.

Mais uma vez, com base nas descrições de suas Memórias, os biógrafos de Afanássiev puderam determinar a sua posição política, tema que sempre foi cercado por dúvidas, já que ele nunca foi dado a efusivas declarações públicas. Além das Memórias, ajudaram na construção de sua imagem política suas amizades e opiniões acadêmicas. Vale ressaltar a importância das citações de Afanássiev pela viva expressividade com

\footnotetext{
${ }^{6}$ Herzen, Passado e pensamentos, Primeira parte, capítulo VI apud Naliépin, A. L. Arqueólogo da antiguidade eslava in Afanássiev, A. N. Povo artista: Mito, folclore e literatura, organizado por A. L. Naliépin, Moscou, Soviétskaia Rossía, 1986, p. 8.

${ }^{7}$ Afanássiev, A. N. Memórias apud Sokolóv, I. op. cit., p. XI.

${ }^{8}$ Idem, p. XIX.
} 
que narra as movimentações políticas do período. Sobre os universitários da sua época, dizia:

Os estudantes da minha época dividiam-se em grupos que se formavam de acordo com a origem social. Assim, havia o grupo dos aristocratas de sobrenome e em parte de fortuna (nesse meio prevaleciam o francês, as conversas sobre bailes, as luvas brancas, os chapéus triangulares); o grupo dos seminaristas; o grupo dos polacos e o grupo (o maior de todos) composto do resto dos estudantes, onde se cultivava principalmente o amor à ciência russa e ao povo russo. ${ }^{9}$

Afanássiev pertencia a esse grupo maior, o dos assim chamados raznotchíntsy ${ }^{10}$ democratas, que, nos anos 1840, formavam a nova intelligentsia em substituição à constituída pela nobreza.

Sobre os professores, havia os pertencentes à ala reacionária, entre os quais, Afanássiev citava o professor de letras S. P. Chevyrióv, professor de Busláev que na época iniciava sua atividade universitária, e o professor de direito civil F. L. Moróchkin.

Sobre o primeiro, Afanássiev dizia não apreciá-lo "pelas convicções que ele se empenhava em transmitir nas aulas - eslavófilo, não tinha de modo algum tendências

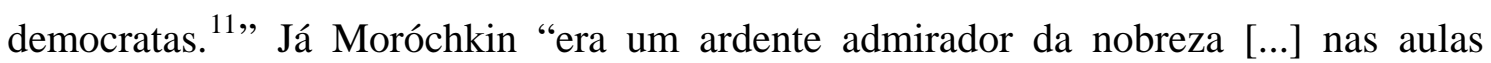
várias vezes dava provas de que as leis eram respeitadas com canhões, baionetas e vigilância nos quarteirões. ${ }^{12 \text { " }}$

O primeiro biógrafo de Afanássiev, A. E. Gruzínski, o vê como alguém que estava significativamente do lado do principal fluxo ideológico e social, sendo solidário com os ocidentalistas, mas que

não participava ativamente nem da elaboração nem da implantação dos princípios, das concepções sobre o mundo às quais ele era adepto na literatura e na vida; não havia nele inclinações nem para ser um combatente nem um pregador ${ }^{13}$.

\footnotetext{
${ }^{9}$ Ibidem.

${ }^{10}$ Nome dado aos intelectuais que não pertenciam à nobreza russa dos séculos XVIII e XIX.

${ }^{11}$ Afanássiev, A. N. Memórias apud Sokolóv, I. op.cit., p. XX.

12 Idem, p. XXI.

${ }^{13}$ Gruzínski, A. E. A. N. Afanássiev (esboço biográfico) in Afanássiev. A. N. Contos populares russos, t. 1. 3 ed, Moscou, 1897, p. XVI-XVIII apud Barág, L. G. e Nóvikov, N. V. A. N. Afanássiev e a sua coletânea Contos populares russos in Contos populares russos organizado, 1984, v. 1, p. 388.
} 
Entretanto, os pesquisadores Barág e Nóvikov, baseando-se em trabalhos sobre o diário e as cartas de Afanássiev ${ }^{14}$, tentam mostrá-lo mais envolvido com a vida política da época, principalmente, por sua proximidade com Herzen e V. I. Kassátkin, ativos representantes da intelligentsia russa.

Esses estudiosos apontam uma intensa troca de informações entre Afanássiev e Herzen, que, vivendo no exterior, era responsável por publicações censuradas na Rússia. Para melhor explicar essa relação, é preciso dar um salto na seqüência cronológica até o ano de 1858, quando Afanássiev, com N. M. Schiépkin, começa a editar a revista bibliográfica e histórico-literária Anais Bibliográficos [Bibliografítcheskie zapíski]. Segundo os autores supracitados, Afanássiev continuamente enviava textos proibidos na Rússia para Herzen, que editava em Londres o periódico A Estrela Polar. O estudo Correspondentes secretos d'A Estrela Polar, de N. Ia. Edelman, apontado por Barág e Nóvikov, afirma que era visível a semelhança entre os materiais que surgiam nos dois periódicos. Herzen tinha como proposta dar livre expressão às idéias oprimidas na Rússia, A Estrela Polar deveria se tornar o “abrigo de todos os manuscritos mergulhados na censura imperial e por ela mutilados”15. Sobre sua posição, Herzen dizia:

Ser a sua tribuna, a sua fala livre e sem censura é o meu objetivo. Nem tanto quero apresentar para vocês algo novo, de minha produção, quanto quero aproveitar minha posição para tornar públicos os seus pensamentos não expressos e anseios mais secretos, transmiti-los aos irmãos e amigos perdidos na muda e distante terra do reino russo ${ }^{16}$.

Como editor dos Anais Bibliográficos, Afanássiev teve a oportunidade ainda de revelar seu jornalismo crítico, velado sob as iniciais I. M., como consta numa carta direcionada ao bibliográfico G. N. Gennadi, de 3 de julho de 1858: “As misteriosas

\footnotetext{
${ }^{14}$ Entre os anos 1960 e 1970, a biografia de Afanássiev foi completada e revista, sobretudo, no que se refere às suas visões sociopolíticas. Isso ocorreu graças ao acesso que uma série de pesquisadores teve ao manuscrito Diário - trechos da minha memória e correspondências, preservado no arquivo do decabrista I. D Iakúchkin, no Arquivo Central Estatal da Revolução de Outubro [Tsentrálnyi Gossudárstvennyi Arkhiv Oktiábrskoi revoliútsii - ЦГАOP]. A partir desse manuscrito, surgiram vários trabalhos biográficos sobre Afanássiev, dentre os quais o de Lazútin, S.G. Diários de A. N. Afanássiev, no qual Barág e Nóvikov se basearam.

${ }^{15}$ Herzen. Tipografia livre russa em Londres. Aos irmãos da Rus in Tcherniétski, L. Dez anos de tipografia russa em Londres. Londres, 1863, p. 7 apud Barág, L.G. e Nóvikov, N. V. op. cit., p. 390.

${ }^{16}$ Ibidem.
} 
iniciais I. M. representam vosso humilde criado; mantenha essa informação somente para si, pois elas devem expressar tudo que há de mais provocativo” ${ }^{\text {17. }}$.

Nas páginas do mesmo periódico, Afanássiev também publicou artigos sobre a literatura do século XVIII: “N. I. Nóvikov”, “Sátiras de Kantemír”, “Fonvízin”, "Polêmica literária do século passado" e sobre a história da literatura do século XIX: “Sobre a correspondência de Karamzín”, "Sobre a poesia de Bátiuchkov”, “Observações à edição das obras de Púchkin”, “Observações sobre Liérmontov” etc.

Em 1861, Afanássiev passa o posto de editor ao amigo Kassátkin que, além de correspondente de Herzen, era seu ajudante também na implantação das tipografias livres ${ }^{18}$.

Retomando sua trajetória universitária, vale lembrar que, embora Afanássiev cursasse a faculdade de Direito, fato que talvez seja explicado pela influência paterna, ele tinha fortes inclinações para a história e a literatura. E, além das suas aulas obrigatórias, freqüentava muitas outras nas áreas de teoria literária, história russa e história da Idade Média.

Em sua área histórico-jurídica, os professores mais admirados por ele eram N. V. Kalátchov, K. D. Kaviélin, S. M. Solovióv, que se destacavam como representantes da ala ocidentalista moderada, os dois últimos tidos como seus mentores.

Perante os olhos do governo, nesses anos em que Afanássiev compartilhava das concepções dessa escola, todos os partidários dessa área não eram vistos como cidadãos leais. Até o mais tímido liberalismo e ocidentalismo privado de quaisquer traços de radicalismo assustavam o tsar Nicolau I (1825-1855) ${ }^{19}$. Paradoxalmente, apesar da forte repressão e censura, o século XIX consolidou-se como o século de ouro da arte e letras russas. Ideologicamente, os integrantes da escola histórico-jurídica eram a favor da implantação do capitalismo na economia rural e da ampliação da atividade comercial e empresarial. Posteriormente, defendiam a necessidade de uma reforma campesina, embora, esperassem que a iniciativa viesse da própria monarquia ${ }^{20}$.

Dentre os professores mencionados, o que se tornou mais próximo de Afanássiev foi Kaviélin que direcionou os interesses do aluno para o estudo da legislação da antiga Rússia e para a história do sistema econômico e do cotidiano do povo. Como resultado

\footnotetext{
${ }^{17}$ Porudóminski, V. I. Eu adoro Púchkin cada vez mais... in Prometeu, t. 10, Moscou, 1974, p. 210 apud Naliépin, A. L., p. 22.

${ }^{18}$ A Tipografia russa livre foi fundada por Herzen em Londres e mais tarde em Genebra. Nela foram publicados periódicos como $O$ sino (Kólokol) e A estrela polar (Poliárnaia Zvezdá).

${ }^{19}$ Naliépin, op. cit. p. 11.

${ }^{20}$ Sokolóv, I. op. cit., p.26.
} 
dessa orientação, Afanássiev publicou, em 1847, ainda durante os anos de estudante, seu primeiro artigo, "Economia estatal no período de Pedro, o Grande”, em $O$ Contemporâneo [Sovremiénnik].

A agitação política de $1848^{21}$ por toda a Europa acabou por reforçar a opinião do tsar Nicolau I que considerava as universidades como verdadeiros centros de idéias liberais e os estudantes e professores revolucionários em potencial. A liberdade universitária foi abalada, sendo submetida a inspeções. Assim, o ministro da educação, conde S. S. Uvárov, tinha como objetivo verificar pessoalmente as tendências políticas do meio docente e discente. Após assistir às aulas, instruía os professores sobre a melhor maneira de ministrar o curso. Afanássiev, já em seu último ano, apresentou ao conde uma aula cujo tema era “A influência do princípio estatal (monárquico) no desenvolvimento do direito penal na Rus dos séculos XVI e XVII” - e, como ele mesmo concluiu em suas Memórias, ingenuamente entrou em discussão com o inspetor, fato que lhe determinaria os seus anos posteriores, impedindo-o de seguir carreira acadêmica e forçando-o a dar aulas em colégios particulares. "Essa aula provocou algumas observações do ministro, com as quais, entretanto, eu não adivinhei imediatamente que tinha de concordar."22

O professorado reacionário, representado por Afanássiev nas figuras de S. V. Chevyrióv e M. P. Pogódin, opositores de Kaviélin e Solovióv e redatores de $O$ Moscovita [Moskvitiánin], apressou-se em descrever no jornal a inspeção ministerial e sublinhar a ligação de Afanássiev com aqueles professores:

Afanássiev é o mais completo representante das novas - como falam concepções sobre a história russa. A opinião de $O$ Moscovita sobre isso, como é conhecida pelos leitores, é praticamente oposta, e por isso se abstém de julgar a palestra, o que talvez fosse tendencioso. ${ }^{23}$

Essa crítica ${ }^{24}$ acabou por alertar o conde Uvárov que tinha a tendência de ver em tudo o que era "novo” algo em contradição com a política oficial. Talvez ela tenha feito o ministro prestar uma maior atenção ao jovem pesquisador.

\footnotetext{
${ }^{21} \mathrm{O}$ ano de 1848 é conhecido, pela profusão de revoluções por toda a Europa, como o ano da Primavera dos povos ou Primavera das revoluções.

${ }^{22}$ Afanássiev, A. N. apud Sokolóv, I. op. cit., p. XVIII.

${ }^{23}$ O Moscovita, 1848, n. 9, p. 7 apud Sokolóv, I. op. cit., p. XXVIII.

${ }^{24}$ Na crítica de M. P. Pogódin, a aula de Afanássiev recebeu um outro nome: "Breve esboço da vida pública dos russos nos três últimos séculos do período pré-Pedro”. Assim, em suas biografias às vezes é possível encontrar tal variação.
} 
Os aborrecimentos causados pela aula inspecionada atrapalharam as expectativas de Afanássiev de seguir carreira acadêmica na universidade e ele acabou se dedicando a dar aulas de língua e literatura russa num colégio interno. Sobre esse período, um dos seus alunos, N. A. Belogolóvi, lembrou-se muitos anos depois, no Diário Russo [Rússkie viédomosti], n. 19, $1897^{25}$,

Como professor de língua russa, tivemos ainda aulas com um tal de A. I. Ivanov, professor talentoso, que atraía a atenção dos alunos pela sua capacidade de tornar interessante até as aulas de gramática; além disso, ele possuía uma rara delicadeza nas sua atitudes. Infelizmente, bebia sem parar e muitas vezes não conseguia ir às aulas, morrendo já no primeiro ano do nosso ingresso no colégio. Todos o amavam muito, e nosso desgosto infantil expressou-se, entretanto, no fato de recebermos com muita hostilidade o professor que o substituiria. Ele veio direto do banco da universidade para nos ensinar, era extremamente tímido e acanhado, não sabendo de forma alguma se relacionar com os alunos, que, imediatamente, perceberam o seu acanhamento e com a crueldade peculiar de sua idade torturavam-no e tiranizavam-no durante as aulas, levando-o frequentemente ao ponto de quase com lágrimas nos olhos implorar para que eles se comportassem nas aulas. Até posteriormente, quando já estávamos nas últimas séries e o reconhecíamos como um maravilhoso professor, não éramos inocentes nessa relação e tomávamos certas liberdades com Afanássiev que não nos arriscaríamos a tomar com outros professores, sabendo que ele, com toda sua profunda doçura, nunca decidiria punir alguém... Sem dúvida, mesmo assim Afanássiev era um dos nossos melhores professores, envolvia-se conosco com fervor e conseguiu semear em muitos de nós o amor e o interesse pela língua e literatura materna [...].

Ao se dedicar ao labor de professor para o qual não tinha desenvoltura, não apreciava e além de tudo era mal-remunerado, Afanássiev passava por difíceis momentos. Numa tentativa de ajudá-lo, Kaviélin tenta trazê-lo para a sua área de estudo, porém não encontrou no ex-aluno uma resposta positiva. Tal tentativa foi expressa numa longa carta em que Kaviélin, além de tentar animá-lo moralmente e se propor a ajudá-lo na organização das suas finanças, recomenda-lhe o aprofundamento no estudo da história da nova legislação russa. No final da mesma carta, Kaviélin diz: "Eu conheci Dal. Ele reuniu quinze mil provérbios. Isto é honrável. Ele fez o mais abundante e completo dicionário de dialetos. E também um mapa geográfico de dialetos russos. O que você pensa sobre isso?”26

Tal comentário chama a atenção dos estudiosos de Afanássiev como um sinal de que os seus interesses científicos já se voltavam para o estudo do folclore e da língua.

\footnotetext{
${ }^{25}$ apud Sokolóv, I. op.cit., p. XXVIII.

${ }^{26}$ Afanássiev, A. N. Memórias, p. LXXXV apud Naliépin, A. L. in op. cit., p. 13.
} 
Em 1849, com a ajuda de N. V. Kalátchov, Afanássiev começa a trabalhar no Arquivo Geral do Ministério das Relações Exteriores de Moscou, onde ficou por treze anos, até 1862. Lá, conseguiu seguir carreira, subindo cada vez mais de posição, e se sustentar financeiramente. Esses anos são considerados como os mais felizes e produtivos da vida de Afanássiev. Durante esse período, ele escreveu quase a totalidade das suas obras, recheadas de muitos artigos publicados em importantes periódicos: $O$ Contemporâneo, de Nekrássov e Panáiev; Os Anais da Pátria [Otiétchestvennie Zapiski], de Kraiéviski; Mensageiro russo [Rússki Viéstnki], de Katkóv; Lingua russa [Rússkaia riétch] de Evguiéni Tur; Diários de São Petersburgo [Sankt-Peterbúrgskie Viédomosti] e Diários de Moscou [Moskóvskie Viédomosti]. Também publicou em almanaques: Kometa, de N. M. Schiépkin e Atenea, de E. Korch e em revistas especializadas: Arquivo de informações histórico-jurídicas referentes à Rússia [Arkhiv istórico-iuriditcheskikh sviédenii otnosiáchtchikhsia do Rossii], de Kalátchov, Boletim do Depto. de língua e literatura russa da Academia de Ciências [Izviéstia Akadiémii Nauk po Otdeliéniiu rússkogo iaziká i slovenosti].

Os seus inúmeros artigos (muitos anônimos), observações críticas e pareceres podem ser agrupados em três partes: a primeira, que diminuiu cada vez mais, é dedicada a questões de história e história do direito; a segunda, muito significativa pelo seu volume, é dedicada a crítica literária, à história da literatura dos séculos XVIII e XIX e ao trabalho bibliográfico (pareceres sobre livros recém-publicados); a terceira, às questões de folclore e etnografia, principalmente, a questões de mitologia eslava e artigos que tinham um caráter de estudos científicos independentes ${ }^{27}$.

O primeiro deles “Economia estatal no período de Pedro, o Grande”, Afanássiev escreveu em 1847, como já mencionado, ainda durante o período universitário. Na área de crítica literária, Afanássiev destacou-se, na segunda metade dos anos 1850, com diversos trabalhos que enfocavam as revistas satíricas do século XVIII, entre eles podemos citar a série "Revistas russas 1769-1774”, publicada nos Anais da Pátria (n. 3, 4 e 6) e que resultou em 1859 no livro Revistas satíricas russas. Um episódio da história da literatura russa do século passado.

O interesse de Afanássiev pelo material folclórico bruto era enorme. Em 1850, ele conseguiu publicar uma substancial quantidade de provérbios populares, reunidos por ele próprio tanto do relato oral quanto de manuscritos, sob o nome de "Complementos e

\footnotetext{
${ }^{27}$ Sokolóv, I. op. cit., p. XXXI.
} 
anexos à coletânea Provérbios e parábolas populares russos", editado por I. Sneguirióv. Esse trabalho saiu no periódico Arquivo de informações histórico-jurídicas referentes à Rússia, de Kalátchov, marcando o início de seus artigos na área de literatura popular. Além da reunião e publicação de obras populares, Afanássiev dedicar-se-ia também ao seu estudo.

No mesmo ano, publicou nos Anais da Pátria "Sobre o significado arqueológico do Domostrói $^{28}$. Ao analisá-lo como uma fonte etnográfica, Afanássiev buscou nessa

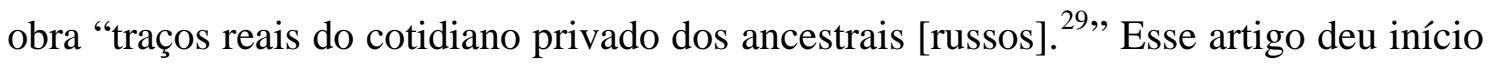
à batalha de Afanássiev com a censura que era contrária exatamente a essa busca pelos traços reais. $\mathrm{O}$ artigo recebeu diversos cortes nos trechos em que falava sobre a rigidez do ensino na Rússia antiga ${ }^{30}$. O período de 1848 até 1854 foi uma época de forte opressão. Outros artigos de Afanássiev que seriam publicados nos Anais da Pátria ou não foram liberados ou o foram apenas parcialmente. De maneira geral, desde seus artigos científicos até suas coletâneas de obras populares, todos os trabalhos de Afanássiev eram alvo da censura. A essas reações, Kraiévski, editor do periódico, aconselhou Afanássiev: "Escreva utilizando mais as indicações das fontes, ou ainda melhor, com as mesmas palavras das fontes, e reflita menos. A censura teme a reflexões. $^{31,}$

Apesar da diversidade de assuntos sobre os quais Afanássiev debruçava-se em seus artigos, o lugar central de suas atividades científicas sempre foi ocupado pelo estudo das obras e crenças populares. Entre eles, uma grande quantidade foi produzida entre 1851 e 1855. O primeiro artigo de Afanássiev sobre mitologia eslava “O vovô domovói” foi publicado no Arquivo de informações histórico-jurídicas... Em seguida, em 1851, no almanaque Kometa saiu "O bruxo e a bruxa”; nos Anais da Pátria, no mesmo ano de 1851, publicou "O significado religioso-pagão da isbá eslava”; em $O$ Contemporâneo (1851) saiu “Bruxaria na Rússia antiga”; em 1852 nos Anais da Pátria publicou um amplo estudo "Divindades zoomórficas dos eslavos: pássaro, cavalo, touro, vaca, serpente e lobo"; em 1853, no Boletim do Depto. de língua e literatura russa da Academia de Ciências, publicou o tratado "Algumas palavras sobre a correlação entre

\footnotetext{
${ }^{28}$ Espécie de código moral utilizado pelas classes dominantes, o Domostrói apresenta regras detalhadas sobre o comportamento social, religioso e sobretudo do cotidiano familiar. Supõe-se que a obra tenha surgido no século XV nos circuitos dos boiardos e comerciantes da cidade de Nóvgorod. Nos meados do século XVI, durante o governo de Ivan, o Terrível, foi revisto pelo arcipreste Silvestre.

${ }^{29}$ Naliépin, A.L. op. cit., 16.

${ }^{30}$ Sokolóv, I. op. cit., p. XXXII.

${ }^{31}$ Gruzínski, A. E. A. N. Afanássiev (esboço biográfico) in Afanássiev. A. N. Contos populares russos, t. 1. 3 ed, Moscou, 1897, p. XXI apud Naliépin, op. cit. p. 16.
} 
língua e crendices populares”; em 1854 no Arquivo de informações..., "Sobre o significado do parto e da parturiente"; em 1855, no mesmo periódico, "Ligação mítica entre os conceitos de luz, visão, fogo, metal, armas e bílis”. Todos eles serviriam mais tarde de base para a obra de três volumes Concepções poéticas dos eslavos sobre a natureza (1866-1869), formada ainda por comentários aos contos e outros trabalhos.

Os artigos sobre a mitologia eslava também não escaparam da censura. Escrito, provavelmente, em 1855 ou 1856, mas impresso com grande atraso em 1861 no Arquivo de informações histórico-jurídicas..., "Observações sobre a vida após a morte nas tradições populares eslavas” foi censurado por falar demais sobre o paganismo e abalar os fundamentos da religião cristã.

Em todos esses artigos, Afanássiev empregava na análise os conceitos da escola à qual ele era adepto, a escola mitológica. Assim, procurava nas manifestações concretas da vida cotidiana russa os antigos traços do sistema mitológico indo-europeu ${ }^{32}$. Afanássiev estava entre os pioneiros na aplicação dos métodos da escola mitológica. Embora essa fosse uma atitude bastante progressista para a época, ele inevitavelmente acabou recebendo críticas a seus possíveis exageros ao buscar as raízes indo-européias em todo e qualquer lugar. Um de seus antigos mentores, o professor Kaviélin, assim expressou-se sobre o artigo "O bruxo e a bruxa”:

É impressionante! O autor dirige-se às crenças indianas para explicar a crendice sobre a ordenha das vacas. Não sabemos por que, antes de lançarse nesse caminho ilusório e duvidoso, no qual tantos talentosos cientistas nossos já se perderam (não seria antes de mais nada uma alusão a Busláev Sokolóv), por que, repetimos, ele não olhou ao seu redor, para mais perto, para a regra segundo a qual seria mais correto explicar as crendices russas a partir do cotidiano russo do que a partir do indiano ou de qualquer outro ${ }^{33}$ ?

Afanássiev, que era um grande admirador dos irmãos Grimm, atraiu-se fortemente pelo método de estudo comparativo, buscando em seus estudos o esclarecimento da origem e desenvolvimento do mito, no cerne do qual ele via a palavra. Assim escreveu em 1860: “A base das pesquisas mitológicas tem de ter [...] um sólido e abrangente estudo da língua, pois nisso se esconde também o embrião (o grão) da fábula e o seu desvendamento. ${ }^{34,}$

\footnotetext{
${ }^{32}$ Naliépin, A. L. op, cit., p. 17.

${ }^{33}$ Anais da Pátria, v. 6, 1851 apud Sokolóv, I. op. cit., p. XXXV.

${ }^{34}$ Apud Naliépin, A. L. op. cit. p. 17.
} 
Para Afanássiev, o caminho da palavra humana era um caminho de perda e decadência, de esquecimento “da ligação primordial entre os conceitos ${ }^{35}$ ”, o sentido inicial da palavra se apaga a tal ponto que começa a sua mitologização. E é então a partir da "fragmentação dessas narrativas míticas” que se forma o alicerce de todos os gêneros folclóricos. Esse mesmo pensamento, Afanássiev aplicou à formação das crenças pagãs. A tarefa primordial das suas pesquisas sobre a poesia popular era a busca pelas suas raízes mitológicas.

No prefácio à primeira edição da coletânea Contos populares russos (1855), Afanássiev claramente explícita seu método científico ao mencionar que o objetivo da edição é explicar a semelhança entre contos e lendas de diferentes povos, apontando o significado científico e poético deles:

Já falamos sobre a semelhança pré-histórica das lendas e crenças de todos os povos da tribo indo-européia. Tal semelhança é condicionada: em primeiro lugar, pela igualdade das impressões primordiais, despertadas no ser humano a partir da natureza observada, adoração que serviu de base para as suas conviç̧ões morais e religiosas na época primeva dos povos. Em segundo lugar, pela mesma antiqüíssima origem dos povos hoje tão separados. Ao se dividirem em diferentes ramos a partir de uma raiz única, esses povos trouxeram de sua vida pregressa muitas tradições semelhantes, e a prova de sua origem inicial se oculta nos sons da língua materna. É provado que a mesma força criadora que formou a língua, formou também as crenças populares e sua fiel representante - a poesia popular; a formação da palavra e do mito ocorria ao mesmo tempo, e a influência recíproca da língua na formação das representações mitológicas e do mito no nascimento da palavra é incontestável ${ }^{36}$

Considerar o mito como a origem dos gêneros folclóricos passou a ser o método adotado pela maioria dos estudiosos.

Um tipo de crítica muito em voga na época, e valorizada pelos representantes da intelligentsia, era a que ressaltava a importância de se revelar o contexto social. Com base nisso, o método científico utilizado por Afanássiev recebeu reproches de Tchernychiévski, que, num tom semelhante ao que Dobrolíubov usaria para se referir posteriormente em 1858 aos Contos populares russos, chamava a atenção dos estudiosos para se preocupar com os fatos atuais da vida do povo.

\footnotetext{
${ }^{35}$ Afanássiev. A. N. Concepções poéticas eslavas da natureza, Moscou, 1865, p. 3 apud Naliépin, A. L. op. cit. p. 18.

${ }^{36}$ Afanássiev, A. N. Prefácio ao primeiro volume da primeira edição in . Contos populares russos, 1957, v. 3, p. 382.
} 
Na revista Arquivo de informações histórico-juridicas..., de 1854-1855, onde Afanássiev publicava seus artigos, Tchernychiévski fez uma crítica na qual, por um lado, dá o devido mérito a Jacob Grimm e a todos os pesquisadores da antiguidade eslava e, por outro, adverte sobre a atração unilateral pelos tempos remotos não ligados à atualidade:

Para os pesquisadores filólogos, entre os quais se destaca Grimm, a antiguidade é importante porque é antiga. Porém, a ciência deve estar a serviço do homem. Quanto mais influência ela puder ter na vida, mais importante ela é. Não aplicada à vida, a ciência é digna de ocupar somente a mente dos escolásticos. ${ }^{37}$

Ainda na mesma revista e epóca, Tchernychiévski crítica dessa vez o artigo de Afanássiev “Ligação mítica entre os conceitos de luz, visão, fogo, metal, armas e bílis”, ao mesmo tempo em que reconhece as conclusões de Afanássiev, julga-as exageradas:

Com quanta desconfiança, por exemplo, muitos olham para a pesquisa de Afanássiev; entretanto, no meio de muitas interpretações mitológicas exageradas e crenças que não contêm nada de mitológico, em seu trabalho frequentemente encontram-se explicações com as quais é impossível não concordar. Muitas dessas explicações estão também no artigo de Afanássiev sobre o qual falamos aqui - "Ligação mítica com a noção de luz, visão etc”. Porém, o desejo de descobrir em todos os lugares os resquícios da mitologia antiga prejudica o sucesso da sua pesquisa ${ }^{38}$.

Exageradas ou não, Afanássiev, atraído pelos estudos da escola mitológica e suas vertentes, estava entre os responsáveis por traçar o caminho dos estudos da até então pouquíssima trabalhada área de crenças e obras populares.

De modo geral, em Moscou, Afanássiev dispunha de uma elevada reputação científica e pessoal, tendo contato com os melhores representantes da sociedade intelectual e da universidade. O círculo literário e filosófico que Afanássiev freqüentava era composto por pessoas notáveis como N. V. Gógol, I. S. Turguêniev, T. N. Granóvski, A. I. Herzen, que se reuniam na casa do grande ator russo Mikhail Semiónovitch Schiépkin ${ }^{39}$. Schiépkin, a quem Afanássiev conheceu no último ano de faculdade, tornou-se um grande e rígido apreciador de suas pesquisas folclóricas. Nesses encontros, as discussões discorriam sobre questões tanto da vida literária e

${ }^{37}$ Tchernychiévski, N. G. Obras Completas, t. 2, 1949, p. 380 apud Propp, V. I. Prefácio in Afanássiev, A. N. Contos populares russos, 1957, v. 1, p. VIII.

${ }^{38}$ Idem, ibidem.

${ }^{39}$ Naliépin, A.L. op. cit., p. 14. 
teatral da época quanto do âmbito político, como o obscurantismo dos líderes religiosos, a situação campesina etc.

A partida de Herzen para o exterior, em 1847, foi lamentada pelo grupo. Aleksandra Schiépkina ${ }^{40}$ se lembrava: “'Sim, ficar e trabalhar mesmo sob ameaças de morte!', exclamou um dos jovens mais fervorosos e ainda inexperientes, que mais tarde seria o conhecido colecionador de contos russos Aleksandr Afanássiev.” ${ }^{41}$ Essa lembrança depõe a favor da idéia de que Afanássiev teria conhecido Herzen durante esses encontros.

Acredita-se que a idéia de criação de uma obra que sistematizasse a mitologia russa como Concepções poéticas... teria nascido das calorosas discussões ocorridas na casa de Shiépkin entre Afanássiev e seu filho Dmitri M. Schiépkin, que era um grande estudioso de mitologia dos povos do Oriente Médio, principalmente Egito, chegando a ter uma publicação póstuma sobre o assunto, já que morreu, em 1858, sem concluí-la. Um trecho desse seu trabalho foi enviado a Jacob Grimm, que assim respondeu: "Em relação à sua introdução para a Mitologia Russa, até onde posso ver ela foi escrita de forma bem fundamentada e com cientificidade, [mas] o mais importante é o próprio trabalho. Se esse trabalho for correspondente à introdução, sem dúvida nenhuma, será muito inovador e útil. ${ }^{42,}$

Apesar de toda a sua intensa produção intelectual, o grande destaque de Afanássiev deve-se ao seu trabalho de reunidor e editor dos Contos populares russos (1855-1863). A idéia inicial dessa obra surge muito antes da sua efetiva realização, talvez influenciada pela publicação dos irmãos Grimm, em 1812, da coletânea Contos da criança e do lar, à qual Afanássiev atribuiu um grande valor científico e pedagógico. Assim, em agosto de 1851, ele escreveu ao editor dos Anais da Pátria A. A. Kraiéviski:

Eu tenho uma proposta para a sua revista. Será que você concordaria em dedicar em seus Anais um lugar na seção "Variedades" ou em alguma outra para os contos populares russos? Eu penso em prepará-los para publicação sob o nome de "contos de lubók". A edição seria científica, seguindo o modelo da edição dos irmãos Grimm. O texto dos contos seria acompanhado dos necessários comentários filológicos e mitológicos, que dariam ainda mais valor a esse material; além disso, os contos idênticos [sic] seriam comparados aos contos alemães da edição dos Grimm e os

\footnotetext{
40 Esposa de Nicolau M. Schiépkin, filho de M. S. Schiépkin, e irmã do literato russo Nicolau Vladímirovitch Stankíevitch.

${ }^{41}$ Schiépkin, M. S. Vida e obra. 2t, t.2, Moscou, 1984, p. LV apud Naliépin, op. cit. p. 14.

${ }^{42}$ Schiépkin, D. M. Sobre as fontes e formas da fábula russa, 1-2, Moscou, 1859-1861, p. XVI. Apud Naliépin, A. L. op. cit., p. 19.
} 
trechos análogos de diferentes contos seriam indicados. Entraria aqui também a comparação dos contos com as canções populares. Para essa publicação, eu faria um pequeno prefácio sobre o significado dos contos e sobre o método da edição científica. Publicaria um conto a cada três ou dois números - dependendo da possibilidade -, o que não ocuparia muito espaço na revista. Além disso, esse não é um assunto desprovido de interesse. Já no que se refere às condições, eu esperaria receber somente pelo prefácio e comentários, os contos seriam de graça, desejaria receber também de 25 a 30 exemplares dessa revista. O que você tem a dizer sobre isso? ${ }^{43}$

Por fim, embora Kraiévski tenha aceitado a proposta, Afanássiev acabou desistindo da publicação no periódico, decidindo que os contos deveriam ser lançados em uma edição separada.

Em 1852, provavelmente por indicação de Kaviélin, Afanássiev foi convidado a se tornar membro da Sociedade Russa de Geografia. Fundada em 1845, ela já dispunha de muito material folclórico, uma vez que desenvolvia uma intensa atividade de coleta local. Em 23 de fevereiro de 1852, o seu Conselho colocou à completa disposição de Afanássiev seu acervo de contos populares. Dessa maneira, Afanássiev obteve a base para a sua obra Contos populares russos, que teve na sua primeira edição oito volumes, lançados ao longo dos anos de 1855 a 1863. O primeiro e o segundo volume tiveram durante esses oito anos três reedições; o terceiro e o quarto, duas ${ }^{44}$. Em busca de uma profunda postura científica, os volumes apresentavam comentários detalhados, com indicações de variantes em coletâneas de contos de outros povos e interpretações com base na escola mitológica, além de - algo totalmente inovador para a época - as variantes. Ambos, comentários e variantes, eram colocados no final de cada volume. Como muitas variantes eram recebidas após o fechamento da edição, os acréscimos ao primeiro e segundo volumes acabaram sendo publicados no fim do segundo, e os acréscimos do terceiro ao oitavo, no oitavo.

No prefácio à primeira edição dos Contos populares russos, Afanássiev mais uma vez declara o seu entusiasmo pelos cientistas alemães:

A grande importância dos contos populares como um abundante material para a língua e literatura popular, filologia e etnografia há muito tempo é reconhecida e consolidada pelos mais talentosos cientistas alemães. Eles não somente se apressaram em reunir seus contos populares e lendas, mas ainda acrescentaram à literatura alemã maravilhosas traduções de quase tudo que foi publicado sobre esse assunto em outros paises. Certamente, em

\footnotetext{
${ }^{43}$ Sokolóv, I. op. cit., p. XLI-XLII.

${ }^{44}$ Isso segundo Propp e Sokolóv. Porém em seus comentários, Barág e Nóvikov dão a seguinte informação: o primeiro, segundo e terceiro volumes tiveram três reedições, e o quarto, duas.
} 
nenhum outro lugar dedicaram-se com tanta seriedade aos monumentos da literatura popular como na Alemanha e, nesse sentido, o mérito dos cientistas alemães é realmente enorme, sendo impossível não desejar que seu nobre trabalho, realizado em beneficio do caráter nacional, nos sirva como um bom exemplo. ${ }^{45}$

Tal admiração pela ciência européia era muito típica de uma época em que havia a aspiração de transpor para o solo russo os êxitos da ciência estrangeira, o que não deixou de ser um fenômeno de significado positivo ${ }^{46}$.

Entre as décadas de 1840 e 1860, era muito debatido na imprensa qual deveria ser a correta forma de coletar as obras orais e quais poderiam ser realmente consideradas populares. Para Belínski e Dobrolíubov, autenticamente populares deveriam ser as obras anotadas no meio popular, antes de tudo das próprias palavras dos camponeses ${ }^{47}$. Afanássiev compartilhava de tal opinião ${ }^{48}$ e, com a edição de Contos populares russos, funda a coleta científica e o estudo dos contos eslavos. A edição do primeiro volume foi muito marcante, já que não existiam coleções de contos populares que prezassem pela sua legitimidade, e fortaleceu o debate de como deveriam ocorrer as pesquisas folclóricas, quais deveriam ser suas preocupações e metas. Até então o autêntico conto popular era praticamente desconhecido, o conto vindo do relato do mujique era ainda desprezado. O interesse social e científico pelo conto popular fortalece-se somente em meados do século XIX provocado pelo interesse das classes progressistas no destino da servidão dos camponeses e no seu cotidiano e visão de mundo. O leitor comum, insatisfeito com as edições cheias de modificações, também passa a dar mais atenção aos contos populares e a abandonar as coletâneas estilizadas como as de M. D. Tchulkóv (1744-1792), e diversas outras do fim do século XVIII e primeira metade do XIX, formadas por traduções de contos fantásticos franceses, de contos de lubók, às vezes de alguns episódios retirados dos autênticos contos populares e mais normalmente da própria imaginação arbitrária do editor. Tal situação foi observada por Afanássiev:

Nosso comércio de livro sempre esteve e continua inundado de uma enorme quantidade de edições inexpressivas, desagradáveis e cheias de erros de impressão, nas quais, sob o nome de contos populares, publicam-se contos tão distorcidos que neles é difícil de encontrar a nossa nacionalidade e até

\footnotetext{
45 Afanássiev, A. N. Prefácio ao primeiro volume da primeira edição in . Contos populares russos, 1957, v. 3, p. 382.

${ }^{46}$ Sokolóv, I. op. cit., p. XL.

${ }^{47}$ Os opositores a essa idéia julgavam o relato dos camponeses analfabetos completamente desprovido de valor e não representativo da cultura nacional.

${ }^{48}$ Barág e Nóvikov, op. cit., p. 413.
} 
mesmo o próprio sentido. Aqui são permitidas tanto traduções quanto modificações e invenções - fruto da imaginação ociosa do editor, e a precisa e expressiva linguagem popular é substituída por um prosa sem expressão e nem sempre exata. Nossas críticas podem ser plenamente aplicadas às edições de contos de Popóv, Tchulkóv e muitos outros. ${ }^{49}$

Das coletâneas anteriores à de Afanássiev, que tinham a pretensão de ter algum significado científico, citam-se: Contos populares russos transpostos da tradição oral popular para a língua escrita civil, adaptados à vida cotidiana e ornamentados pelos ditos do cossaco Vladímir Luganski. Os cinco primeiros, de 1832. Tal coleção, editada por Dal, já que Vladímir Luganski era seu pseudônimo, praticamente não teve divulgação, sendo confiscada pela censura logo após o seu lançamento por causa do conto, na verdade, não de origem popular, "O quinto conto sobre as aventuras do diabo seminarista.” Após catorze anos, Dal reeditou esses cinco contos numa outra coleção: Novelas, contos e narrativas do cossaco Luganski (1846), formada por contos populares modificados literariamente.

Em 1838 foi publicada a coletânea Contos populares russos, de Bogdán Bronítsyn, reunindo cinco contos que, segundo o prefácio, foram anotados “das palavras de um contador ambulante, camponês dos arredores de Moscou, que os ouviu de seu velho pai ${ }^{50}$,. Esses contos serviram de material para a coletânea de Afanássiev que os republicou e comentou.

Em 1841, surgiram os Contos populares russos, de I. P. Sákharov. No prefácio, o editor fala muito sobre as suas “peregrinações pelos campos e vilarejos” para “coletar as tradições populares dos remotos tempos passados" e, no prospecto de seu Narrativas do povo russo, lançado no mesmo ano, em terceira edição, ele fervorosamente ataca os editores que publicam contos em edições de lubók com acréscimos e mudanças arbitrários, dizendo: “Isto é uma mancha negra em nossa cultura nacional, devemos

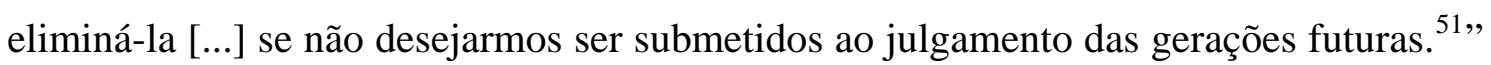
Tal afirmação de Sákharov suscita a idéia de que em sua coletânea só haveria contos populares autênticos, mas, segundo Sokolóv, posteriormente esses contos foram desmascarados por estudiosos que comprovaram que Sákharov não somente retirou seus contos de diversas edições de lubók como também os submeteu as suas desonestas falsificações.

\footnotetext{
${ }^{49}$ Afanássiev, A. N. Prefácio ao primeiro volume da primeira edição in Contos populares russos, 1957, v. 3, p. 384.

${ }^{50}$ Sokolóv, I. op. cit., p. XLIII.

${ }^{51}$ Ibidem.
} 
A partir dessa relação das edições de contos populares da primeira metade do século XIX, é possível mais ainda avaliar a importância do aparecimento da edição científica de Afanássiev em 1855.

Além do material da Sociedade Russa de Geografia, que formou praticamente os três primeiros volumes, Afanássiev contou também com uma enorme quantidade de contos doados a ele por Dal. O estudioso possuía uma grande coleção de contos populares, mas, ao ter de se dedicar ao intenso trabalho de edição dos dicionários da língua russa e de provérbios, resolveu doá-los. Como resposta ao pedido de Afanássiev, feito em carta, para que ele lhe fornecesse os contos, Dal respondeu em outubro de 1856: “[...] eu tenho algumas pilhas de contos reunidos, certamente, há muito lixo nisso, e também muitas repetições. Eu não pretendo publicá-los, pois tenho muitos outros trabalhos (dicionário). Quando eu ordená-los, os entregarei. ${ }^{52,}$

Dessa rica compilação que Afanássiev recebeu, mais de mil textos, ele selecionou cerca de 150 textos (número, segundo Sokolóv, difícil de precisar já que a partir desse

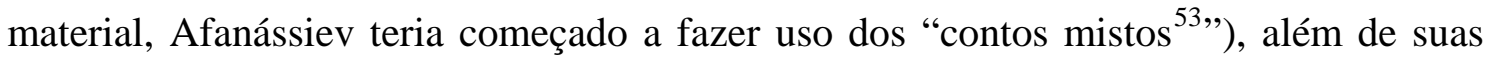
variantes, que formaram o conteúdo do quarto, quinto, sexto e sétimo volumes. Muitos contos ainda ficaram de fora por seu conteúdo, como pode ser observado no prefácio de Afanássiev ao quarto volume:

Para concluir, acrescento que alguns contos muito interessantes da coleção de Dal, infelizmente, não foram liberados para publicação por serem indiscretos em seu conteúdo: como é o caso de alguns em que o herói é geralmente o funcionário dos popes. Nesses contos, há muito humor, e muita liberdade é dada à fantasia. ${ }^{54}$

Além dos contos vindos da Sociedade e da coleção de Dal, Afanássiev republicou nos Contos populares algumas edições de lubók e alguns textos espalhados em periódicos e em compilações do fim do século XVIII, do gênero da coletânea Remédio contra devaneios e insônia ${ }^{55}$, caso julgasse esses textos genuinamente populares.

A grande maioria dos textos reunidos por Afanássiev não possuía a identificação de quem os anotou, ou pela simples falta do nome do coletor ou pela grafia ilegível.

\footnotetext{
${ }^{52}$ Trecho da carta de V. I. Dal apud Barág, L.G. e Nóvikov, N. V. op. cit., p. 412.

${ }^{53}$ No original svódnyi tiékst. Textos que resultam da reunião de diversas variantes. Essa idéia é defendida por estudiosos como Sokolóv.

${ }^{54}$ Afanássiev, A. N. Prefácio ao quarto volume da primeira edição Contos populares russos, 1957, v. 3, p. 394.

${ }^{55}$ Essa coletânea de 1786 tornou-se muito popular no fim do século XVIII, tendo várias reedições até os dias de hoje.
} 
Dentre as exceções, havia textos recolhidos por P. I. Iakúchkin, que coletava principalmente canções e mais raramente $\operatorname{contos}^{56}$, e pelos seus amigos de Vorónej, Aleksandr-Dólnik e N. I. Vtórov, etnógrafo, especialista na região de Vorónej e líder da intelligentsia local. Isso tudo mostra que Afanássiev muito dependia do envio de material para as coleções.

É importante observar que a quantidade de contos anotados por ele próprio não ultrapassou dez ou onze, sendo todos recolhidos na província de Vorónej. Isso explícita o fato de ele não pertencer ao grupo de coletores de obras orais que iam diretamente até o povo, sendo, portanto, um organizador, editor e comentarista dos contos populares. Entre os folcloristas que eram verdadeiros coletores, citamos: Khudiakóv com sua obra Contos grão-russos (em três volumes, 1860-1862); Rýbnikov com Canções reunidas por P. N. Rýbnikov (1861 a 1867), que chamaram muito a atenção por ser um sinal inesperado do nível de vivacidade, principalmente na região Norte, em que ainda se encontrava a tradição épica no campesinato daquele tempo; Iakúchkin com Canções populares russas da coletânea P. I. Iakúchkin (1865); A. F. Hilferding, que realizou em 1871 uma viagem para o Norte em busca de bilinas, tendo como resultado Bilinas de Onega, lançado em 1873; e o primeiro volume de Lamentações da região Norte, anotados por E. V. Bársov e editado em 1872, que, em sua maioria, eram interpretadas por Arina Fedóssova ${ }^{57}$. Essa pequena relação atesta também a intensa produção de fundo científico que se iniciou após o lançamento da coletânea de Afanássiev. No século XX, destacaram-se entre outros N. E. Ontchukóv (Contos do Norte, 1908) e Zeliénin (Contos grão-russos da província de Perm, 1914 e Contos grão-russos da província de Viátka, 1915).

No total, a coletânea Contos populares russos possui cerca de 600 textos, sendo alguns em bielo-russo e ucraniano, com uma natureza muito diversificada (contos, anedotas, dokútchnye ${ }^{58}$, pribaútki ${ }^{59}$ ). Apesar de ser desejo de Afanássiev, a primeira

\footnotetext{
${ }^{56}$ Tais anotações, ele transmitiu ao conhecido colecionador de canções P.V. Kiriévski, que, por sua vez, as transmitiu a Afanássiev.

57 Arina Fedóssova (1831-1899) era uma camponesa iletrada muito conhecida por impressionantes interpretações de lamentos. Entre seus admiradores estavam Gorki, Rimski-Korsakov e Niékrassov, que, baseado em motivos de suas lamentações, compôs o seu poema Quem vive bem na Rússia?

${ }^{58}$ Dokútchnyi, literalmente, significa chato, importuno. Dokútchnaia skázka é uma manifestação folclórica caracterizada por uma narração breve, sem sentido e geralmente infinita, terminando com uma pergunta que retoma o seu início, repetindo-se a mesma coisa, o que o comprova o seu significado literal de importuna. Muito utilizada como resposta aos constantes pedidos das crianças para que se conte um conto. Ex: "Quer que eu lhe conte o conto [skázka] sobre o bezerro branco?" - "Conte" - "Você conta, e eu conto, e você quer que eu lhe conte o conto [skázka] sobre o bezerro branco?" -“Conte" - "Você conta, e eu conto, e sobre o que e até quando? Quer que eu lhe conte o conto [skákza] sobre o bezerro
} 
edição não teve uma sistematização científica dos contos por conteúdo, pois ele os imprimia à medida que os obtinha, o que não possibilitava a partir de um todo fazer a classificação.

Tal tarefa, ele empreendeu durante a revisão da obra para a segunda edição, classificando-os em três grupos principais: contos sobre animais, contos de magiafantásticos, contos de costumes ou novelísticos ${ }^{60}$. Na segunda edição, a quantidade de comentários sobre os contos foi reduzida, já que muitos foram incluídos na obra Concepções poéticas... Os que restaram fariam parte do quarto volume da nova edição.

Afanássiev dependia essencialmente das suas fontes, da qualidade dos manuscritos, o que sem dúvida gerava irregularidades como o fato de ora se ter ora não o local onde o conto havia sido anotado, alguns contos mantinham a pronúncia local, outros não; da mesma forma, alguns eram anotados com muita precisão e outros se perdiam em um relato literário. Mesmo com tantas dificuldades textuais, defende-se a idéia de que Afanássiev mantinha a autenticidade dos contos, não os adaptando, no máximo, fazendo pequenas correções.

Esse fato, acrescido da utilização de variantes e de uma preocupação em sistematizar a ordem dos contos, era visto como um avanço em relação ao trabalho dos precursores de Afanássiev e até mesmo dos irmãos Grimm, que utilizaram uma ordem aleatória na disposição dos contos, dispensaram variantes e tratavam os textos com bastante liberdade, restabelecendo o espírito nacional que alguns tinham perdido ${ }^{61}$.

Sobre essa questão, Aleksandra Schiépkina recordou-se das palavras de Afanássiev:

Por mais de uma vez ele falou sobre as dificuldades em reunir os contos: 'Pensam que isto é fácil, que é somente eu ouvir e anotar, mas não sabem o

branco?” (Af. 531) ou "Você quer que eu lhe conte uma dokútchnaia skázka?" -“Conte" - "Você fala: conte, e eu falo: conte; você quer que eu lhe conte uma dokútchnaia skázka?” -"Não precisa." - "Você fala: não precisa, e eu falo: não precisa; você quer que eu lhe uma dokutchnaia skázka?” (Af. 532).

${ }^{59}$ Pribaútka é um gênero do folclore, que se apresenta na forma de um palavreado sempre com objetivo cômico. Fortemente rimada e ritmada, é de fácil memorização, geralmente é introduzida em falas ou em obras orais de outros gêneros: bilina, contos, onde, embora não tenha nenhuma ligação com o assunto, confere-lhes um tom humorístico. No nosso folclore, talvez o gênero que mais se aproxime tanto da pribaútka quanto da dokútchnaia skázka seja a parlenda. Ex: "Era um nabo impressionante, toda velha se surpreendia; em um dia não tinha como dar uma volta nele; metade desse nabo nossa família comeu a semana inteira, e a outra metade, na outra semana; juntamos a casca e pusemos em cima da carroça, estafamos o cavalo e quebramos a carroça. Olha que coisa séria que aconteceu numa outra manhã!" (Af. 546).

${ }^{60}$ A grande maioria dos contos da coletânea Contos populares russos é do tipo conto de magia. Propp, v. I. Comentários in Afanássiev. A. N. Contos populares russos, 1957, p. 463.

${ }^{61}$ Sokolóv, I. op. cit, p. XXIV. 
quanto é preciso comparar cada conto com suas variantes, resolver o que incluir e o que deixar de fora, compondo um conto das diversas variantes, e como, além disso, é preciso limpar a língua, excluindo tudo o que há de rude e áspero.' Essas são as autênticas palavras de Afanássiev, até onde as recordo, já que as ouvi uma só vez. ${ }^{62}$

Entretanto, a questão sobre o quanto os contos foram modificados é muito polêmica. Quando na citação de Schiépkina, Afanássiev diz "resolver o que incluir e o que deixar de fora, compondo um conto das diversas variantes”, tem-se a impressão de ele criar um terceiro conto a partir de variantes, isso não seria um forte tipo de interferência editorial? Talvez ele já estivesse se referindo aos "contos mistos”. Ou quando ele diz: “é preciso limpar a língua, excluindo tudo o que há de rude e áspero”, não estaria ele mascarando a linguagem verdadeira? Possivelmente, diante das obras até então publicadas repletas de contos retrabalhados, pseudopopulares, as intervenções de Afanássiev fossem praticamente irrisórias.

Propp afirma que “Afanássiev manteve seu ponto de vista de inviolabilidade do texto e apenas em casos isolados introduziu algumas correções redacionais. ${ }^{63 \text { ” }}$

De qualquer forma, a publicação da coletânea de Afanássiev recebeu diversas observações e sugestões da parte de importantes filólogos da época como Pypin, Busláev, Oreste Miller etc. ${ }^{64}$ No geral, todos os críticos parabenizavam os Contos como o descobrimento de um tesouro da criação popular, relacionando-o ao despertar do interesse da sociedade pela vida das massas populares. Pypin em Anais da Pátria (n. 12, 1855), comenta:

Nós não somente desejamos sinceramente sucesso ao trabalho de Afanássiev, como também temos plena convicção do seu sucesso. Com esse interesse pelo espírito nacional, que se manifesta na ciência e na arte, o público esclarecido sem dúvida valorizará "A coletânea de contos populares”, que satisfaz a exigências críticas próprias desse tipo de edição... O nome do autor já serve como garantia de uma séria compreensão do assunto, e o público certamente dá o devido valor à sua edição, que é a primeira experiência a dar explicações científicas aos contos populares russos e a expô-los na sua forma inerente ${ }^{65}$.

\footnotetext{
${ }^{62}$ Arquivo Estatal Central de Literatura e Arte, f. 126 (arquivo Gruzínski) apud Naliépin, A.L. op. cit., p. 20.

${ }^{63}$ Propp, V. I. Prefácio in Afanássiev. A. N. Contos populares russos, 1957, v. 1, p. X-XI.

${ }^{64}$ Uma lista detalhada pode ser vista no livro de S. V. Sávtchenko. Rússkaia naródnaia skázka: istória sobirániia i izutchiéniia (Conto popular russo: história da coletânea e do estudo), Kiev, 1914, p. 141.

${ }^{65}$ Apud Sokolóv, I. op. cit., p. XLV.
} 
Mas além de elogios, Afanássiev recebia também críticas em relação à língua, ao estilo e até a própria composição dos contos para a edição.

Em relação à língua, apontavam as tentativas de ele dar a exata transcrição fonética e de manter os traços dialetais. Isso era resultado do anseio de Afanássiev em seguir literalmente o que encontrava nos originais; mesmo quando a anotação era feita sem habilidade, ele mantinha suas incongruências. Os editores responsáveis pelas posteriores reedições dos Contos populares corrigiram muitas dessas incoerências, mesmo assim é possível ainda encontrar a forma falada em vez da escrita ou ainda diferentes grafias para uma mesma palavra.

O mesmo Pypin numa outra crítica ( $O$ Contemporâneo, n. 12, 1856, p. 31) escreveu:

O senhor Afanássiev seduziu-se pelo exemplo dos irmãos Grimm, que publicaram alguns contos nos dialetos alemães; mas isso não pode se tornar uma regra geral pelo simples fato que a maior parte dos contos não pertence exclusivamente a uma região, mas a todo um povo [...] e apresentar os contos num dialeto de Tambov seria incoerente com o principal objetivo do trabalho. ${ }^{66}$

Em relação ao estilo, alguns críticos, entre eles o supracitado, achavam que Afanássiev deveria alterar os contos, conseguindo uma narração fluente e um texto ideal, eliminando tudo o que houvesse de subjetivo e vulgar, originário do contador. Esse pensamento denota muito a idéia de que era esperado que houvesse um discurso padrão, aceitável para a obra popular, sem traços pessoais do narrador, que representasse a língua de todo um povo. Na mesma crítica, Pypin se expressou:

O editor mantém rigidamente os manuscritos a partir dos quais publica seus contos. Por isso, junto com o popular, entrou muito do vulgar, quase obsceno: esta última característica sempre pertence somente a um narrador particular e surge da sua incapacidade de transmitir os relatos populares ou da incapacidade do coletor de anotá-las. A presença desse vulgarismo ou do elemento obsceno na narração dos contos excessivamente prejudica a qualidade dos contos, pois as formas simples e harmoniosas da fala popular, freqüentes nos contos que se aproximam da linguagem poética das canções e bilinas, são substituídas por uma linguagem que pertence a um lado rude e não poético do cotidiano popular ${ }^{67}$.

\footnotetext{
${ }^{66}$ Idem, p. XLVI.

${ }^{67}$ Idem, p. XLVII.
} 
Já Busláev, ao comentar sobre o lançamento da coleção, parece se opor a possíveis correções, dizendo que alguns contos

[...] são renovados por alfabetizados, ao que parece com bem pouco êxito; seria bem melhor se não fossem publicados até o momento em que houvesse a oportunidade de ouvi-los em um relato verdadeiramente popular russo. [...] as canções e os contos sem isso já sofreram, passando de geração para geração. Para que então colocar a mão no trabalho de séculos de um povo inteiro? ${ }^{68}$

Sem dúvida, Afanássiev queria dar à sua coletânea um verdadeiro caráter científico. Por isso, mantinha todos os traços lingüísticos, julgando impossível, pelo menos até o terceiro volume, quando ainda não havia se influenciado pelos críticos, introduzir correções no texto. Porém, em alguns casos, dependendo das características e da qualidade das anotações, ele realizava pequenas correções, o que aos olhos dos críticos eram praticamente insignificantes, já que se opunham exatamente ao fato de Afanássiev não corrigir os textos. O trecho abaixo apresenta nas palavras de Afanássiev quando ele fazia uso de correções:

Com sua benevolente colaboração, a Sociedade [...] resolveu disponibilizar para mim as coleções de contos que possuía. [...]. Essa maravilhosa coleção apresenta enormes curiosidades. Muitos dos contos foram anotados de forma excelente, mantendo todas as particularidades da fala popular; entretanto, outros foram anotados com uma língua mais literária do que popular, nem sempre gramaticalmente correta, mas isenta de qualquer arbitrariedade, de qualquer modificação inventada propositalmente. Publicando os primeiros, eu segui exatamente os manuscritos obtidos; em relação aos últimos, eu me permiti corrigir palavras e erros gramaticais. ${ }^{69}$

A respeito da composição, os críticos condenavam a desigualdade de enredos entre os contos, considerando que alguns eram apresentados de forma incompleta. Porém, isso poderia depender da qualidade dos manuscritos. Novamente, pelas palavras de Pypin $^{70}$ (Anais da Pátria, n. 4, 1856, p. 51), pode-se observar o conselho que era dado a Afanássiev:

\footnotetext{
${ }^{68}$ Busláev, Mensageiro russo, 1856, n. 2, p. 94 apud Barág, L.G. e Nóvikov, N. V. A. N. op. cit., p. 41415.

${ }^{69}$ Afanássiev, A. N. Prefácio ao primeiro volume da primeira edição in Contos populares russos, 1957, v. 3, p. 386.

${ }^{70}$ Os estudos científicos dedicados aos trabalhos de Afanássiev não sugerem que os comentários de Pypin tenham ocasionado alguma indisposição entre os dois cientistas. Ao contrário, Afanássiev parece ter até mesmo acatado algumas opiniões. Em uma carta de 1859 ao amigo, crítico literário, publicista e pedagogo, M. F. De-Pule, Afanássiev diz: "Em relação à edição dos meus Contos, já estou saturado da leitura de diversos artigos baseados no absoluto desconhecimento dessas questões e dos trabalhos dos
} 
Ele [Afanássiev] poderia manter as formas dos manuscritos recebidos de uma maneira não tão rígida, pois eles foram anotados por pessoas que certamente não eram especialistas na literatura popular e nem sempre de bons contadores. O colecionador tem o objetivo de chegar a uma forma adequada da obra e por isso não deveria valorizar o que era acrescentado por apenas uma pessoa. Ele não deveria se deter também na fragmentação [variantes] das narrativas populares; se o seu tato crítico o convence que em dois certos contos ou canções ele ouve trechos de uma só coisa, ele tem a possibilidade de juntá-los: isso não seria uma arbitrariedade, e as novas pesquisas certamente confirmarão tal conjectura. ${ }^{71}$

Na coletânea de Afanássiev, enquanto alguns contos parecem acabar inesperadamente ou deixar pontos sem resolução, outros são extremamente detalhados e coerentes. Há também contos em que talvez se possa observar a influência do comentário acima, são contos que, além de se destacarem pela sua extensão, aproximam-se muito de uma narrativa tipicamente literária. Porém, determinar isso com exatidão é realmente dificílimo, tal variação pode ser apenas resultado da diversidade de manuscritos recebidos. É provável que Afanássiev tenha seguido as sugestões de Pypin e unido alguns contos, criando os “contos mistos”; isto é, de diversas variantes, criava um único texto. Alguns estudiosos, como Sokolóv, afirmam que Afanássiev ${ }^{72}$, a partir do quarto volume da primeira edição, teria começado a criar esse tipo de texto. O trecho a seguir mostra que para Gruzínski tal idéia era uma suspeita:

Essa idéia [de realizar os contos mistos] - fala Gruzínski - leva à seguinte frase do prefácio para o quarto volume: 'Ela (coleção de Dal) é muito abundante em variantes e se isso, por um lado, significativamente diminui a sua quantidade de contos, por outro, temos a possibilidade de comparar um manuscrito com outro e pelo menos aproximadamente reconstruir o conto popular na sua simplicidade original.

E Gruzínski completa: “Baseando-se nisso, supomos que talvez Afanássiev tenha aplicado o sistema de textos mistos aos contos.”73

Segundo Sokolóv, se essa prática de Afanássiev trazia ganhos do ponto de vista puramente literário, já do ponto de vista histórico-literário, certamente, esses textos mistos apagavam a criação original dos contadores e dificultavam a precisão da informação sobre o folclore autêntico.

cientistas alemães. Podemos e devemos excluir somente os artigos de Pypin que são realmente excelentes e proveitosos.” Apud Barág e Nóvikov, op.cit., p. 418.

${ }^{71}$ Apud Sokolóv, I. op. cit., p. XLVIII.

${ }^{72}$ Sokolóv, I., op. cit., p. XLIV.

${ }^{73}$ Apud Sokolóv, I. op. cit., p. L. 
Um outro tipo de crítica típica da época era a que propunha um enfoque sociopolítico sobre as obras de criação popular. Assim, entre as diferentes opiniões sobre a coletânea de Afanássiev, uma especialmente interessante por ter tal abordagem foi a feita por Dobrolíubov, após o lançamento do quarto volume da coleção, na nona edição do periódico O Contemporâneo, em 1858. Nela, Dobrolíubov questionava o significado da ciência em geral:

A coletânea de Afanássiev supera as outras pela sua completude e precisão, com a qual ele procura manter a fala popular, até mesmo as pronúncias, mas até a coletânea de Afanássiev não elimina aquela falha que de forma tão desagradável afeta todas as nossas coletâneas. Essa falha é a absoluta ausência de ligação com a vida real... Extrair o fato da viva realidade e colocá-lo na prateleira ao lado de volumes empoeirados ou classificar alguns fatos soltos e fortuitos, baseando-se em uma divisão de lógica escolar - isso significa eliminar a vivacidade que existia nesse fato ligado com a realidade que o cerca. [...] Nenhum dos coletores e descritores do cotidiano popular nos explicou em que relação se encontra o povo com os contos e tradições por ele narrados. Por isso nos parece que qualquer um que anote e colha as obras da poesia popular faria algo muito útil se não se limitasse à simples anotação do texto do conto ou da canção, mas transmitisse todo o meio externo e interno, moral, no qual ele conseguiu ouvir tal canção ou conto. ${ }^{74}$

Segundo Propp, Dobrolíubov, ao chamar a atenção dos coletores para a descrição da vida real do povo, pede para que eles se atenham à situação econômica do camponês da época, mencionando as precárias condições das isbás, que não dispunham nem mesmo de fornos com chaminés, a alimentação composta de pão podre e ralas sopas de repolho, ou seja, o estado de constante fome e miséria. Dobrolíubov chama, portanto, de “meio externo”, as manifestações de ordem social que ocorrem no local onde se ouviu o conto ou a canção. Já de “meio interno” pode-se entender que Dobrolíubov apontava a necessidade de o coletor descobrir a ligação entre o povo e os contos e tradições populares contados por ele.

As observações desse conhecido representante da democracia revolucionária indicam o significado que a poesia oral ganhou na vida social nos anos 1860 e a função que ela começou a desempenhar no interesse para compreender o popular, isto é, a vida camponesa $^{75}$, que tanto envolveu a intelligentsia russa de então. Porém, a todas essas exigências de Dobrolíubov, a coleção de Afanássiev não pôde responder, e elas se tornaram premissas para os futuros pesquisadores e coletores.

\footnotetext{
${ }^{74}$ Idem, p. LI.

${ }^{75}$ Ibidem.
} 
Dando seqüência às suas coletâneas, em $1860^{76}$, Afanássiev lança Lendas populares russas. Uma coletânea de 33 lendas, obtidas principalmente da coleção de Dal, sobre a vida dos santos e de Cristo. A tiragem inicial de 1200 exemplares esgotouse em três semanas. Tanto sucesso foi explicado pelo seu conteúdo considerado perturbador: a visão popular sobre o cristianismo, numa avaliação, certamente, não tradicional. Ao contrário do que se podia imaginar, essas lendas não expressavam um sentimento devoto nem de fidelidade do povo aos ensinamentos da Igreja, e sim uma postura negativa e até mesmo maliciosa em relação à moral religiosa.

Logo a censura se pronunciou, pois o livro Lendas populares russas havia sido liberado pela censura laica, porém a religiosa não tinha sido consultada, o que fez com que o procurador-geral do Sínodo, o conde A. P. Tolstói, se dirigisse ao ministro da educação E. N. Kovaliévski nas seguintes palavras:

Em relação à publicação (ou seja liberação) em Moscou pelo censor Naúmov do livro do senhor Afanássiev intitulado Lendas populares russas, o reverendíssimo metropolita Filariét dirigiu-se a mim em carta na qual explicou que naquele livro freqüentemente se fala de Cristo e dos santos e, por isso, a censura laica deveria aconselhar-se com a clerical, porém ela não o fez; [explicou ainda] que o nome de Cristo salvador e dos santos estão envolvidos em contos ultrajantes do sentimento de devoção, da moral e da decência, sendo necessário encontrar meios para defender a religião e a moral das blasfêmias e insultos dessa obra. ${ }^{77}$

A solução encontrada foi a proibição de uma segunda edição por mais de cinqüenta anos, até 1914. Além disso, como represália, nessa mesma época, a edição dos Anais Bibliográficos também foi temporariamente interrompida pela censura. Segundo Gruzínski, ao se espalharem os boatos que as Lendas seriam retiradas de circulação, elas passaram a ser compradas por um valor até cinco vezes superior ao real e lidas até mesmo pelas damas.

Sobre o destino do seu trabalho, assim Afanássiev refletia:

[...] a humanidade sente-se atraída por tudo o que é proibido. Eu estou convencido que, na Rússia, o pior e menos liberal livro poderá ter sucesso, se só por brincadeira for proibido, e, vice-versa, a obra mais inteligente e

\footnotetext{
${ }^{76}$ Propp em seu Prefácio indica como data de publicação dessa obra 1859, porém em todos os outros materiais consultados, a data indicada foi 1860. Há discordância de opiniões também em relação ao lugar onde a obra foi lançada pela primeira vez. Alguns acreditam que ela saiu primeiramente em Londres e logo após em Moscou, já outros acreditam no inverso. De qualquer forma, se antes ou depois, o fato que a levaria a ser lançada no estrangeiro, por meio da impressa de Herzen, seria a fuga da censura.

${ }^{77}$ Apud Sokolóv, I. op. cit. p. LII.
} 
liberal pode passar despercebida se for sabido com antecedência que ela não desagrada ao governo... As pessoas não conseguem entender que nessas narrações populares há mil vezes mais moral do que nos sermões cheios de retórica. ${ }^{78}$

Vítimas da censura seriam também mais tarde o quinto e sexto volumes dos Contos populares russos:

[...] o quinto e o sexto volumes deveriam sair juntos, mas... a censura prendeu um livro, apenas por esses dias recebi a metade do manuscrito ferido e coberto de tinta sangrenta. Tudo que foi mutilado, sou forçado a jogar totalmente fora e depois começar a imprimir o que sobreviveu. ${ }^{79}$

Entre seus materiais, Afanássiev dispunha ainda de uma série de contos, novamente da coleção de Dal, que jamais seriam liberados pela censura por causa do seu conteúdo cáustico e indecente: cheios de uma mordaz sátira camponesa aos senhores de terra e popes, mostrando as relações entre os mujiques e os popes ou os senhores de terra. Esses contos, distantes de uma análise mitológica e ricos em franqueza e sinceridade camponesa e no uso de descrições naturalistas e expressões rudes, formaram a obra Contos populares russos proibidos ${ }^{80}$, lançada, anonimamente, em 1872, na Suíça, mantendo-se por duas edições (1872 e 1878). Na Rússia, seria publicada somente em 1991. Essa coletânea é uma seleção de contos do manuscrito Contos populares russos não publicáveis 1857-1862. Composto na sua maior parte de contos populares de costumes, mas também de magia, lendários, sobre animais, assim como ditados, provérbios e causos, esse manuscrito seria publicado na sua íntegra somente em 1997. A coletânea tem como fio condutor o erotismo, sobre isso se expressa o seu misterioso prefaciador da edição suíça ${ }^{81}$ :

O conteúdo erótico de Contos populares russos proibidos, sem falar nada nem contra nem a favor da moralidade do povo russo, apenas aponta para o lado da vida que dá maior liberdade ao humor, à sátira e à ironia... A seção de contos sobre a assim chamada pelo povo "natureza de garanhão", dos quais apresentamos apenas uma pequena parte, revela claramente a opinião

\footnotetext{
${ }^{78}$ Apud Gruzínski, A. E. A. N. Afanássiev (esboço biográfico) in Afanássiev. A. N. Contos populares russos, t. 1, 3. ed., Moscou, 1897, p. XXIII apud Naliépin, A.L. op. cit., p. 21.

${ }^{79}$ Carta de Afanássiev a Pekarski, p. 75 apud Barág, L.G. e Nóvikov, N. V. op. cit., p. 392.

${ }^{80}$ No original Rússkie zaviétnye skázki. Zaviétnyi pode ser também íntimo, secreto. Em suas traduções para o francês, essa obra já recebeu os seguintes títulos: Contes secrets russes e Contes érotiques russes.

${ }^{81}$ Não há certeza sobre quem seria o prefaciador, alguns pesquisadores acham que era Afanássiev, outros, Kassátkin, que também é visto por alguns estudiosos como o responsável por levar os originais da obra para o estrangeiro.
} 
e a verdadeira compreensão do nosso mujique sobre os seus sacerdotes espirituais. $^{82}$

Segundo Barág e Nóvikov, a formação dessa coletânea poderia ter sido influenciada pela famosa carta de Belínski a Gógol, onde ele diz:

Sobre quem o povo russo narra contos obscenos? Sobre o pope, sua esposa, sua filha e seu empregado. A quem o povo russo chama raça de imbecis, bajuladores e garanhões? Aos popes. Não seria o pope na Rússia e para todos os russos o representante da gula, avareza, bajulação e semvergonhice ${ }^{83}$

Para Sokolóv, essa coletânea, juntamente com os contos de costumes e anedotas presentes em Contos populares russos, é uma demonstração que Afanássiev em algum momento se afastou das suas interpretações mitológicas, dedicando-se ao folclore do ponto de vista realista ${ }^{84}$. Mais do que isso, para Barág e Nóvikov, essa coletânea testemunha ainda a percepção de Afanássiev a respeito da sociedade e as suas simpatias para com o campesinato russo. No prefácio à primeira edição de Contos populares russos, Afanássiev assim se expressa sobre esse outro tipo de conto: “[...] em seu desenvolvimento posterior, o conto também se submete a novas exigências, nascidas do desenvolvimento da vida que se seguiu, surge então como um obediente e forte instrumento do humor e da sátira popular. ${ }^{85,}$

Em 1860, Afanássiev viajou pela primeira vez ao estrangeiro. Visitou a Alemanha, a Suíça e a Itália, onde testemunhou fatos políticos e homenagens populares a Garibaldi. De acordo com suas cartas, é possível dizer que ele sentia uma profunda empatia pelo momento histórico italiano:

Aqui Garibaldi é absolutamente um herói popular, falam sobre ele com grande admiração [...] Os cantores ambulantes, que percorrem todo o Norte da Itália, cantam, acompanhados de instrumentos, livres cantatas e hinos especialmente compostos para os acontecimentos políticos atuais, nos quais zombam bastante do rei napolitano e da Áustria e expressam elogios verdadeiros a Garibaldi e a Vitório Emanuel como defensores da liberdade e unidade italiana. ${ }^{86}$

\footnotetext{
${ }^{82}$ Prefácio à obra Contos populares russos proibidos apud Barág, L.G. e Nóvikov, N. V. op. cit., p. 390.

${ }^{83}$ Belínski, V. G. Obras completas, 13 vol., Moscou, AN-URSS, 1956, v. 10, p. 215 apud Barág, L.G. e Nóvikov, N. V. A. N. op. cit., p. 423-24.

${ }^{84}$ Sokolóv, I. op. cit., p. LIV.

${ }^{85}$ Afanássiev, A. N. Prefácio ao primeiro volume da primeira edição in Contos populares russos, 1957, v. 3, p. 389.

${ }^{86}$ Apud Sokolóv, I. op. cit, p. LV.
} 
Afanássiev também realizou uma breve passagem por Londres, onde teria se encontrado com Herzen para, segundo alguns pesquisadores, entregar-lhe os originais de Contos populares russos proibidos ${ }^{87}$.

Em 1861, Afanássiev passa o editorial de Anais Bibliográficos para o comando de V. I. Kassátkin, que era então um dos organizadores em Moscou do grupo revolucionário Terra e Liberdade (Zemliá e Vólia) ${ }^{88}$. Por fim, em 1862, Kassátkin foi para a Suíça, onde acabou ficando definitivamente, uma vez que as autoridades russas o haviam condenado à perda de todos os seus direitos e ao exílio.

\section{Os últimos anos}

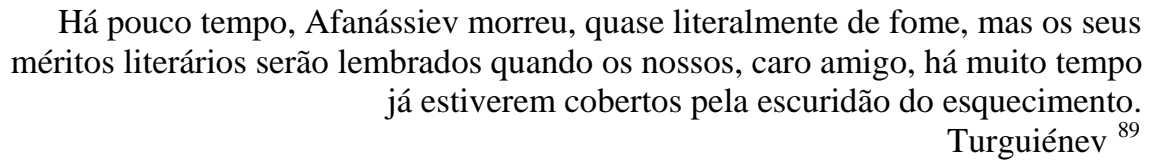

Em 1862, Afanássiev teve sua casa invadida pela polícia que revirou todos os seus documentos em busca de algo que o comprometesse. Embora não tenham encontrado nada de significativo, ele passou a ser visto como alguém suspeito. Logo após essa visita, Afanássiev foi demitido do Arquivo Geral do Ministério das Relações Exteriores de Moscou e proibido para sempre de trabalhar em um serviço estatal, o que o abalou profundamente.

Diversos motivos poderiam endossar essa imagem sobre Afanássiev como a sua dedicação à arte popular e crenças pagãs, a publicação da coletânea Lendas populares russas, censurável do ponto clerical e governamental, sua viagem ao estrangeiro. Mas a busca policial foi desencadeada pela descoberta de que Afanássiev havia recebido inesperadamente em sua casa um imigrante clandestino, colega de Herzen, V. I. Kiélsiev, vindo do exterior com o objetivo de promover uma espécie de atividade revolucionária ${ }^{90}$. Tal visita permaneceria em segredo, se não fosse a polícia ter apreendido uma carta do próprio Kiélsiev que mencionava o encontro.

\footnotetext{
${ }^{87}$ Esse fato é colocado como provável por Sokolóv. Em Barág e Nóvikov, cogita-se a idéia de que o material teria sido levado por Kassátkin quando ele foi para a Suíça.

${ }^{88}$ Barág, L.G. e Nóvikov, N. V. op. cit., p. 394.

${ }^{89}$ Turguiénev em carta a Fiét, 8/1/1872 apud Fiét, A. A. Minhas memórias. Moscou, 1890, parte II, p. 246. apud Naliépin, op. cit., p. 4.

90 Sokolóv, I. op. cit., p. LVI.
} 
A invasão na casa de Afanássiev e o motivo da sua demissão recebem novos dados na visão de Barág e Nóvikov. Segundo os quais, a invasão na casa teria sido desencadeada pelo fato de naquele ano iniciar-se uma busca por suspeitos de terem alguma ligação com Herzen e com a imigração revolucionária. Mesmo não tendo encontrado nada que o incriminasse, o responsável pela investigação dirigiu-se ao tsar, na época então Aleksandr II (1855-1881), assim como ao chefe do Arquivo onde Afanássiev trabalhava, apresentando-o como um cidadão suspeito, o que deveria ser levado em consideração no caso de alguém que tinha o cargo dele, ou seja, que trabalhava num arquivo de documentos estatais que sob hipótese nenhuma poderiam ser divulgados. O tsar parece ter concordado com tal aviso, e Afanássiev foi demitido ${ }^{91}$.

A partir da demissão, Afanássiev caiu em profunda crise financeira, sendo obrigado a vender a sua tão especial biblioteca para se sustentar e a dormir sobre os exemplares do periódico onde ele era editor, como pode ser lido no texto do editor D. E. Kojántchikov dirigido a um dos autores da revista Antiguidades Russas [Rússkaia Stariná]:

Vivendo num apartamento apertado e frio, sem saber com o que cobrir o chão de cujas fendas soprava o vento frio, Afanássiev usava no lugar do tapete todos os exemplares [...] dos Anais Bibliográficos, cujas folhas ele separava e cobria o chão com grossas camadas, e quando essas folhas depois de algum tempo se gastavam eram varridas como lixo. ${ }^{92}$

Somente quatro anos depois, ele conseguiu um trabalho como secretário da Duma de Moscou, seguido ainda de um posto no tribunal de juízes de paz $^{93}$ e por fim em um banco comercial, este último um ano antes da sua morte. Todos esses trabalhos tomavam muito o tempo de Afanássiev, além de estarem bem longe de seus interesses científicos. Mesmo assim, ele conseguiu ainda terminar a preparação da segunda edição dos Contos populares russos, lançada postumamente em 1873, um livro de contos populares para crianças Contos populares russos infantis e também os três volumes do seu conhecido Concepções poéticas dos eslavos sobre a natureza (1866-1869), composto por diversos artigos de mitologia eslava já publicados e revisados pelo autor, uma das mais importantes fontes de informação sobre as crenças dos antigos eslavos e sobre seus posteriores vestígios.

\footnotetext{
${ }^{91}$ Barág, L.G. e Nóvikov, N. V. op. cit., p. 399.

92 Efriémov, P. A. A. N. Afanássiev in Antiguidades Russas, 1872, n. 5, p. 789 apud Barág, L.G. e Nóvikov, N. V. op.cit., p. 400.

93 Juiz com atribuições para conhecer e julgar pequenas causas.
} 
A publicação de Contos populares russos infantis, que também teve dificuldades com a censura, ocorreu em 1870. Essa obra era formada por contos retirados da coletânea Contos populares russos. Sobre a idéia dessa nova edição, Afanássiev fala em uma de suas cartas: "Nos últimos tempos, tive a idéia de publicar alguns contos selecionados da minha coletânea com ilustrações para crianças, mas estou encontrando dificuldades tão inexplicáveis por parte da censura que tenho vontade de largar tudo. ${ }^{94,}$

Há muito Afanássiev recebia pedidos de pais e educadores para a criação de uma obra direcionada ao público infantil, entre eles estava o eslavista Ismail Ivánovitch Srezniévski, que, em uma carta de 1855, sugeriu:

Relendo seu livro (Contos populares russos), eu não o escondi de meus filhos e até o meu Viátchka de seis anos deu-lhe uma espiada... Em conseqüência disso, eu, na função de pai, dirijo-me ao senhor encarecidamente com um pedido: "Seria possível publicar paralelamente a essa edição para cientistas uma outra para crianças? Somente o texto, com a grafia correta e com a explicação das palavras incompreensíveis em rodapé $^{95}$."

Em carta de 18 de novembro de 1855, Afanássiev respondeu à proposta de Srezniévski:

A sua idéia de, ao se editar os contos, ter em vista também os pequenos leitores já foi cogitada por mim... Mas antes de iniciar essa edição para as crianças, gostaria de reunir mais contos e cuidadosamente compará-los com os de outros povos: espero que você aprove minha intenção ${ }^{96}$.

Mas quase um ano antes, em dezembro de 1854, Afanássiev, em seu prefácio ao primeiro volume da primeira edição de Contos populares russos, já demonstrava reconhecer o valor pedagógico dos contos:

[...] além da qualidade poética e científica de tal coleção, ela pode ser útil à educação inicial, apresentando divertidas histórias para a leitura das crianças. Obviamente, ao empreender uma edição com este último objetivo, é preciso realizar uma rigorosa seleção, mas tal seleção pode ser facilmente realizada. Ao se envolver na ingênua fantasia do conto popular, o pensamento infantil imperceptivelmente se acostumará à simplicidade das

\footnotetext{
94 Apud Ivankov, V. M. Estudo de Afanássiev do folclore como meio de expressão da consciência popular in Questões de filologia e metodologia de pesquisa. Vorónej, 1975, p. 47 apud Barág, L.G. e Nóvikov, N. V. op. cit., p. 418.

95 Apud Gruzínski, A. E. A. N. Afanássiev (esboço biográfico). Afanássiev. A. N. Contos populares russos, t. 1. Moscou, 3. ed., 1897, p. XXXIX-XL. Apud Naliépin, A. L. op. cit., p. 3.

${ }^{96}$ Idem, p. 4.
} 
exigências estéticas e à pureza dos ímpetos morais e conhecerá a pura língua popular, suas expressões precisas e suas descrições artísticas fiéis à natureza ${ }^{97}$.

Muitos anos se passaram da idéia original até a sua conclusão em 1870 e, por questões de censura, uma segunda edição seria lançada somente em 1886.

É impressionante observar como, apesar de todas as dificuldades, Afanássiev sempre manteve uma intensa dedicação científica por toda a sua vida.

Essa sua postura de total dedicação e abnegação talvez tenha atingido a sua saúde e, em outubro de 1871, embora tenha recorrido tanto aos tratamentos dos médicos moscovitas quanto ao kumys $^{98}$ dos arredores de Samara, Afanássiev morreu de tuberculose, aos 45 anos. Seu corpo foi enterrado no cemitério Piátnitskoe, na mesma área de seus antigos conhecidos como Mikhail Schiépkin, Granóvski, Korch e Stankiévitch.

Talvez por se manter forçosamente afastado dos meios literários nos seus últimos anos de vida, a morte de Afanássiev não teve grande repercussão na imprensa. W. R. S. Ralston (1828-1889), estudioso do folclore russo, tradutor para o inglês de Contos populares russos e antigo conhecido de Afanássiev, divulgou sua morte na imprensa inglesa antes ainda de ela ter sido anunciada na russa.

[...] Algumas semanas atrás, a literatura russa perdeu um dos seus mais dignos representantes. A morte precoce de Afanássiev deixou uma lacuna no campo dos cientistas eslavistas, que não será facilmente preenchida... Na área específica da sua atividade, ninguém o superará. Como colecionador e comentador dos contos populares russos, ele não tinha concorrentes. Ninguém fez para o bem comum tanto quanto ele. ${ }^{99}$

O valor de Afanássiev nunca foi esquecido, qualquer trabalho sobre a história dos estudos folclóricos na Rússia citará o seu nome. Ainda que as idéias contidas em seu livro Concepções poéticas dos eslavos sobre a natureza tenham se tornado obsoletas, ele ainda é tido como uma importante referência. Contos populares russos, Lendas populares russas e Contos populares russos proibidos formam um conjunto de textos representantes da criação popular que sem dúvida consumiram muita energia e devoção de Afanássiev. O mérito do seu esforço em reunir e editar tantos textos e de praticamente inaugurar o interesse por esse tipo de trabalho é indiscutível.

\footnotetext{
${ }^{97}$ Afanássiev, A. N. Prefácio ao primeiro volume da segunda edição in Contos populares russos, 1957, v. 3, p. 395.

${ }_{98}^{98}$ Leite de égua fermentado.

${ }^{99}$ Ralen, n. 35, 1871, p. 491 apud Barág, L.G. e Nóvikov, N. V. A. N. op.cit., p. 406.
} 


\title{
III \\ O conto popular russo (skázka)
}

\author{
Conto é balela, canção é o que era. \\ (Skázka - skládka, a piésnia - býl, ditado)
}

Diversos estudiosos já se debruçaram sobre a difícil tarefa de definir o termo skázka. Muitos inclusive dedicaram-se ao estudo desse gênero ausentando-se da sua determinação. Em termos gerais, se consultarmos dicionários específicos, teremos como definição para a palavra skázka um gênero de criação popular oral, em prosa, sendo impreterivelmente de caráter fictício e tendo muitas vezes no seu enredo a participação de representantes de forças fantásticas. Sua transmissão ocorre pelo boca a boca, e seus narradores poderiam ser tanto uma pessoa comum quanto alguém especializado. Nem sempre, porém, esse tipo de criação foi chamada de skázka e vice-versa, ou seja, a palavra era outrora aplicada de maneira diferente.

Até o século XVII, a Rússia antiga e medieval desconhecia o significado atual desse termo. Isso não significa que as skázki, como conhecemos hoje, não existiam, mas que eram designadas por outra palavra. Supõe-se que para tal conceito era usado o termo basn (antiga forma de básnia), à qual correspondia o verbo báiat' (falar, narrar, contar) e o substantivo bákhar, contador de histórias, narrador. ${ }^{1}$ Atualmente, básnia significa fábula (o gênero), sendo também utilizado, de forma coloquial, como sinônimo de conversa fiada, tagarelagem.

Inicialmente, skázka significava a palavra dita ou escrita, que tinha o poder de um documento. Assim, nas anotações de A. Bólotov², lê-se: "Eles (camponeses) estando satisfeitos, entregaram [...] uma amistosa skázka.” (no sentido de acordo, documento). Com o mesmo sentido, no conto “Feitor" (Burmístr ${ }^{3}$ ), de Turguiénev, tem-se:

\footnotetext{
${ }^{1}$ Propp. V. I. O conto popular russo (Rússkaia skázka), 2005, p. 16-17.

2 Andriéi Timofiéevitch Bólotov (1738-1833), escritor russo, autor dentre outros livros de Vida $e$ aventuras de Andriéi Bólotov, publicado pela primeira vez entre 1871 e 1873. Tal obra ocupa um lugar de destaque na literatura russa memoralística. Nela, de maneira ingênua, mas imparcial, Bólotov descreve a história da sua vida e da sociedade que o cercava, apontando os abusos e desordens do regime social da época. Sua Vida e aventuras serve como um rico material de estudo sobre a nobreza provinciana russa do século XVIII.

${ }^{3}$ Pertencente ao livro Anotações de um caçador (Zapíski Okhótnika, 1852).
} 
“resolvemos, meu caro, tudo graças ao senhor. Há três dias assinamos a skázka.” Na linguagem oral, a expressão "tomar uma skázka", nos tempos antigos, correspondia à expressão “colher um depoimento”. Na obra de Gógol, Almas mortas, eram chamadas de revízskaia skázka as listas dos nomes dos camponeses que pertenciam a um proprietário de terra, conferidas pela fiscalização, tendo assim o valor de um recenseamento. Portanto, skázka era sinônimo de um depoimento fidedigno, escrito ou oral, ou um testemunho com força jurídica ${ }^{4}$.

A partir do século XVII, entretanto, ela começa a receber mais um significado. Em um decreto do tsar Aleksiéi Mikháilovitch, de 1649, lê-se: “muitas pessoas, por falta de discernimento, acreditam em sonhos, em encontros [...], no agouro de pássaros,

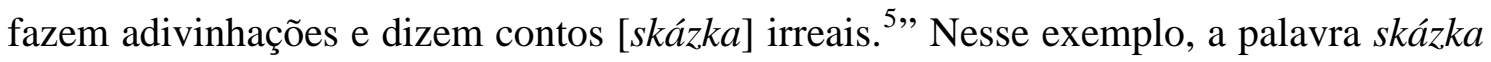
já se volta mais para o seu significado atual. Os fatos que levaram a tal mudança de sentido e à sua nova aplicação (ao que antes era chamado de basn) são difíceis de serem identificados. Provavelmente, aquelas skázki, ou seja, depoimentos, que eram colhidos durante os processos jurídicos, acordos comerciais etc., eram, via de regra, tão pouco confiáveis e tão cheios de mentiras que a palavra, inicialmente compreendida como um documento fidedigno, tornou-se sinônimo de mentira, invenção, algo completamente falso. $^{6,7}$

Assim, atualmente, além de definir um gênero folclórico, skázka também é empregada com o significado estendido de mentira, invenção, história sem fundamentos, absurda:

[...] O senhor está insinuando que o crime foi cometido pelo meu irmão. [...] Saiba que antes de o senhor dizer, eu já tinha ouvido sobre essa invenção tola [glúpaia skázka] e não acredito em nenhuma palavra dita nela. Conheço essa história e como e por que ela foi inventada. [... $]^{8}$. Ou

\footnotetext{
${ }^{4}$ Propp, V. I. op. cit., p. 17.

${ }^{5}$ Ibidem.

${ }^{6}$ Idem, p. 18.

${ }^{7}$ Michèle Simonsen em seu livro $O$ conto popular (1987), traduzido do francês, apresenta uma trajetória semelhante a da palavra skázka para a palavra conto (conte). "Historicamente, o sentido da palavra variou muito. No sentido de 'relato de coisas verdadeiras', ela é encontrada até Malherbe. Na Renascença, tem ainda duplo sentido: 'relato de coisas verdadeiras', mas também 'relato de coisas inventadas'. O Dictionnaire de l'Academie de 1794 define o conto como 'narração, relato de alguma aventura, quer seja verdadeira, fabulosa, séria, ou engraçada’, e acrescenta: ‘é mais comum para as fabulosas e engraçadas’ com isso indicando uma transição para o sentido moderno de 'relato de fatos, de acontecimentos imaginários, destinados a distrair’ (Dictionnaire Robert).” (p. 1).

${ }^{8}$ Dostoiévski, F. Crime e castigo (Prestupliénie i nakazánie), sexta parte, capítulo cinco. Disponível em $<$ http://www.e-kniga.ru/Dostoevskiy/prestup31.html>
} 
[...] - Peço que acredite em mim, pois se não acreditar não há razão para eu falar. Meu pai, Bulavin, é seu inimigo e é também meu inimigo... Ele queria me executar, eu fugi de Sâmara... [...] - Minha cidadã, como posso acreditar em você, se está contando histórias mentirosas [skázki] ${ }^{9}$.

A partir do século XIX, a skázka, de origem popular, começou a ganhar a atenção dos ambientes letrados. E é na primeira metade desse século que temos Púchkin como o grande criador da skázka literária. Baseando-se nas tradicionais skázki populares, Púchkin e seu contemporâneo Jukóvski foram responsáveis pelas primeiras criações literárias do gênero, agora então escritas em versos.

Finalmente, o termo skázka, a princípio fortemente ligado ao conto popular, de criação camponesa, recebeu um amplo significado, servindo para designar os mais diversos tipos de narrativas em que existam elementos semelhantes ao do conto popular e em que o fantástico, o extraordinário estejam presentes. Assim, recebem o nome de skázka desde as clássicas coleções de contos, populares ou não, como a dos irmãos Grimm, de Andersen e de Perrault, As mil e uma noites, até as mais diversas coletâneas de historinhas para crianças, a obra de Lewis Caroll, Alice no país das maravilhas ou as histórias de Walt Disney.

A amplitude da utilização que o termo possui propicia que ele aceite diferentes traduções. Porém, no contexto desta dissertação, cujo objetivo é a tradução e apresentação de contos colhidos no interior da Rússia, sem data nem autoria, transmitidos oralmente, ricos em traços da tradição e vida popular, optamos pela tradução de skázka como conto popular. Difícil seria dar a mesma tradução para a obra de Lewis Caroll ou Walt Disney, ou até mesmo para as skázki em versos de Púchkin. O que explica o fato de existirem traduções que optaram, em vez de conto popular, por contos maravilhosos, contos de fadas, contos infantis etc. Como termos correspondentes a skázka, em outras línguas, apresentamos a seguinte relação: em alemão, Märchen; inglês, tale; francês, conte; italiano, fiaba; búlgaro, prikazka; polonês, bajka; bielo-russo e ucraniano, kazka, baika. ${ }^{10}$

\footnotetext{
9 Tolstói, A. N. "Manhã sombria” (Khmúroe útro), terceiro livro da trilogia O caminho dos tormentos (Khojdiénie po múkam). Disponível em <http://az.lib.ru/t/tolstoj_a_n/text_0220.shtml>

10 Nikíforov, A. I. Skázka (O conto popular). Literatúrnaia entsiklopiédiia (Enciclopédia literária). Disponível em <http://feb-web.ru/feb/litenc/encyclop/lea/lea-7681.htm>
} 


\section{Sobre a classificação}

Uma questão que até os dias de hoje gera muita polêmica entre os estudiosos de todo o mundo do conto popular é a sua correta classificação. O movimento de coleta e divulgação dos contos populares ocorrido nos séculos XIX e XX gerou tal necessidade, mas, nenhuma das classificações é considerada totalmente satisfatória ${ }^{11}$. Entre os pesquisadores do assunto, o finlandês Antti Aarne destaca-se por ter publicado em 1910 um índice de tipos de contos populares, propondo-se a realizar uma sistematização detalhada desses contos, a partir do material acumulado em diversas coletâneas européias. Os enredos [siujiét] repetidos, Aarne chamou de tipos de conto $^{12}$. Tal catálogo foi publicado pela primeira vez em alemão Verzeichnis der Märchentypen, na cidade de Helsinki, na série Folklore Fellows Communications (FFC). Cada tipo de conto recebeu um nome e um número. Assim, para se identificar qualquer conto, independentemente de sua língua, basta indicar o número do seu tipo, com apenas esse dado é possível saber de qual narrativa se trata. Aarne prestou dessa forma um inestimável favor para a ciência mundial da área. Muitas coletâneas de contos populares, de caráter científico, passaram a adicionar às suas edições essa lista de tipos.

O índice de Aarne foi traduzido e adaptado por diversos estudiosos em todo o mundo. Em 1928, o folclorista americano Stith Thompson encarregou-se da tradução para o inglês do texto, ampliando o sistema de classificação de tal maneira que se tornou co-autor do trabalho; desde então o índice The types of the folktale passou a ser conhecido como o Índice Antti Aarne/Stith Thompson (AT ou AaTh) ${ }^{13}$, sendo utilizado até os dias atuais. Em 1961, Thompson lançou uma segunda edição dessa obra.

De maneira resumida, a classificação proposta nesse índice divide-se primeiramente em cinco grandes grupos que se subdividem até chegar a unidades temáticas. Assim temos: Contos de animais (identificados com os números 1 a 299); Contos propriamente ditos (300-1199), entre os quais se encontram os contos de magia; Facécias ou anedotas (1200-1999); Contos formulares (2000-2399) e Outros - tipos não classificados (2400-2499). ${ }^{14}$

\footnotetext{
${ }^{11}$ Algumas falhas sobre os sistemas de classificação, entre eles o de Antti Aarne, são apontadas por Propp em $O$ conto popular russo, 2005, p. 50-51.

${ }^{12}$ Propp, V. I. op. cit., p. 48.

${ }^{13}$ A sétima edição de Contos populares russos, 1984-1985, preparada pelos pesquisadores L. G. Barág e N. V. Nóvikov, apresenta a classificação dos contos de Afanássiev segundo o índice AT.

${ }^{14}$ Folktale types in University of Wisconsin. Department of Scandinavian Studies. Disponível em $<$ http://scandinavian.wisc.edu/mellor/taleballad/pdf_files/motif_types.pdf>
} 
Na Rússia, o responsável pela tradução e adaptação da obra de Aarne foi N. P. Andréiev. Lançado em 1929, o Índice de tipos de conto popular segundo o sistema de Aarne (Ukazátel skázotchnykh siujiétov po sistiéme Aarne) incluía as referências dos contos presentes nas mais novas coletâneas russas. Por muito tempo, esse foi o sistema de classificação utilizado para os contos populares russos, conhecido pela sigla AA (Aarne-Andréiev).

Muito antes, porém, dessas realizações, Afanássiev já havia percebido a importância de elaborar uma classificação para os contos populares. Assim, embora não tenha conseguido esse feito na primeira edição de Contos populares russos (18551863), já que publicava os contos à medida que os recebia, realizou-o na segunda, lançada em 1873. Nessa edição, da qual Afanássiev não presenciou o lançamento, já que faleceu em 1871, o material recolhido já foi posicionado de maneira sistemática, embora Afanássiev não tenha dividido sua coletânea em partes nem intitulado os capítulos. Ao analisar essa segunda edição, Vladímir Propp identificou a presença dos seguintes grupos: “contos sobre animais, aos quais foram acrescidos contos sobre objetos, plantas e fenômenos da natureza; contos de magia, mitológicos e fantásticos; bilinas; narrativas históricas; contos novelísticos ou de costumes; bylítchki ${ }^{15}$; anedotas; dokútchnye ${ }^{16}$; pribaútiki $^{17,18}$

Afanássiev em nenhum momento explicou sua classificação. O enorme material que ele estudou foi separado de maneira natural nesses grupos. Propp reconhece esse trabalho de classificação de Afanássiev como a melhor das tentativas ${ }^{19}$ e a tomando como base, propõe na sua obra Rússkaia skázka (O conto popular russo), na qual estuda o gênero como um todo e não apenas o conto de magia, como fez em suas obras anteriores, sua própria classificação. Assim, após descartar algumas das manifestações orais populares consideradas por ele não pertencentes ao específico gênero do conto popular $^{20}$ e incluir um novo grupo, Propp destaca quatro grandes categorias: contos

\footnotetext{
${ }^{15}$ Narrativas sobre um encontro verdadeiro com forças impuras, do além, como mortos e espíritos da água (vodianói, russálka), floresta (liéchi) etc.

${ }^{16}$ Ver nota 58, cap. 2, p. 49.

${ }^{17}$ Ver nota 59, cap. 2, p. 50.

${ }^{18}$ Propp, V. I, op. cit., p. 46-47.

${ }^{19}$ Idem, p. 46.

${ }^{20}$ Os motivos que fizeram Propp descartar algumas manifestações populares são por ele apresentados em O conto popular russo, p. 47.
} 
sobre animais; de magia; novelísticos também chamados de contos de costumes (incluindo as anedotas) e acumulativos ${ }^{21}$ (categoria por ele acrescentada) ${ }^{22}$.

Dessas quatro categorias, iremos nos deter apenas na descrição de alguns traços do conto popular de magia, assunto da nossa tradução. Um trabalho detalhado sobre as características de cada uma dessas categorias pode ser encontrado na obra acima citada Rússkaia skázka.

\section{Traços gerais}

Os contos populares de magia (volchiébnaia skázka) são considerados um dos gêneros folclóricos mais fiéis à tradição, fornecendo informações sobre crenças, costumes e idéias do homem primitivo ${ }^{23}$. Como traço diferencial do conto de magia das demais categorias (animais, de costumes e acumulativos) tem-se a presença, no primeiro, do “outro mundo” (tot sviét, tridessiátoe tsárstvo) ${ }^{24}$. Mesmo que a presença do sobrenatural exista em outros tipos de conto, como nos contos de costumes onde surge um diabo (contos do tipo diabo enganado), essa presença está totalmente adaptada à vida comum, cotidiana e sempre tingida de comicidade. O diabo não é apresentado como uma terrível criatura do além, mas como algo terreno e real, passível de ser enganado, feito de bobo, recebendo o mesmo status dos outros personagens ${ }^{25}$.

Um dos traços marcantes do conto de magia em relação aos outros está na particularidade do seu estilo. Numa narrativa de intenso ritmo, rica em rimas, embora seja em prosa, encontram-se diversas fórmulas (trechos típicos, clichês, geralmente obrigatórios e esperados para o desenvolvimento da obra), repetições, epítetos, provérbios, peculiares ao conto de magia. Entre essas fórmulas, podemos citar as utilizadas para iniciar o conto, chamadas de prískazka, e as que o concluem, kontsóvka (conclusão). As prískazki ${ }^{26}$ são fórmulas com o propósito de divertir, normalmente não têm nenhum vínculo semântico com o conto que a segue, tendo o único objetivo de

\footnotetext{
${ }^{21}$ Caracterizado por uma longa série de episódios encadeados sucessivamente, que se repetem até o momento de um desenlace final. Na coleção de Afanássiev, entre outros, temos: "O tiérem da mosca" (82-84) e "O nabo" (89).

${ }^{22}$ Propp, V. I. op. cit., p. 47.

${ }^{23}$ Sokolóv, I. Le folklore russe, 1945, p. 235.

${ }^{24}$ Gruel-Apert, L. La tradition orale russe, 1998, p. 128.

${ }^{25}$ Propp, V. I. op. cit., p. 273-274.

${ }^{26}$ Prískazka é o nome que recebe a pribaútka quando utilizada no início do conto. Disponível em $<$ http://feb-web.ru/feb/litenc/encyclop/le9/le9-2551.htm>
} 
chamar a atenção do ouvinte/leitor ${ }^{27}$. Com a frase "Isto é a prískazka, a skázka vem em seguida”, o narrador produz um efeito cômico e desperta o interesse do público. É preciso lembrar que elas não são inerentes ao conto popular, e sim um gênero independente. Na coletânea de Afanássiev, são raros os contos que se iniciam com elas. Porém, podemos citar duas, uma presente no conto "Ivan Sutchiénko e Biélyi Poliánin” (139) e outra em “A cegonha e a garça” (72).

(139) Começa ${ }^{28}$ o conto de Sivko, de Burko, do alazão sábio ${ }^{29}$. No mar, no oceano, na ilha Buián ${ }^{30}$ está o touro assado ${ }^{31}$, do seu lado a cebola socada; e passaram três jovens valentes, entraram, tomaram café da manhã e seguiram seu caminho - e andando se divertiam, se gabando: "nós estávamos, irmãos, em um tal lugar, comemos mais massa do que come uma camponesa!” Isto é a prískazka, a skázka vem em seguida.

(72) Voava uma coruja - uma coruja alegre, ela voou, voou e pousou e balançou a cauda e olhou para todos os lados e voou de novo; voou, voou e pousou e balançou a cauda e olhou para todos os lados... Isto é a prískazka, a skázka vem em seguida.

Após a prískazka ou na sua ausência, o conto apresenta logo no início uma das mais tradicionais fórmulas utilizadas para marcar o seu real começo e o seu espaço e tempo indefinidos:

Em certo reino vivia... (V niékotorom tsárstve jil-byl - $104^{32}$ ),

Em certo reino, em certo estado, viviam... ( $V$ niékotorom tsárstve, $v$ niékotorom gossudárstve jil-byl - 141),

Era uma vez... (Jil-byl - 161).

A kontsóvka, a conclusão do conto, geralmente é carregada de humor e muitas vezes é uma maneira de lembrar que o conto terminou e que seu narrador merece uma recompensa. Entre elas, podemos citar: "Dê uma concha de cerveja para mim, que o conto chegou ao fim. (Dáli mne píva koriéts, moiéi skázke koniéts. - 141). Mas há também fórmulas finais mais corriqueiras como

\footnotetext{
${ }^{27}$ Sokolóv, I. op. cit. p. 241.

${ }^{28}$ Nessas poucas linhas, o autor misturou diversos personagens, lugares e situações presentes nos contos populares, o reconhecimento desses elementos por parte do ouvinte/leitor e a intensa rima (presente no original russo) provocam um efeito cômico e de diversão.

29 Referência ao cavalinho mágico, personagem dos contos populares Sivko-burko e ao seu epíteto: o alazão sábio. Sivko-burko, o alazão sábio (Sivko-Burko, viéschaia kaúrka)

${ }^{30}$ Ilha Buián, lugar fantástico no qual há um carvalho onde está guardada a morte de Koschiéi, o imortal.

${ }^{31}$ Prato que aparece em alguns contos.

32 Apresentam-se aqui os trechos transliterados, para que se possa observar a sonoridade das expressões originais, seguidos do número do conto na coletânea de Afanássiev de onde se retirou a citação.
} 
[...] eles viveram juntos e felizes para sempre (oní jíli vmíeste i dólgo i stchástlivo - 269)

[...] passaram a viver tranqüilos e felizes e a prosperar (vmiéste jit'-pojivát', dobrá najivát' - 172).

As fórmulas ainda estão presentes no corpo do texto, onde marcam o tempo indefinido do conto. Assim, podemos citar:

Nem muito nem pouco, o tempo passou (Prochló ni mnógo, ni malo vriémeni - 201)

Ele seguiu por um tempo nem longo nem curto (Iékhal on dólgo li, kórotko li-172).

No corpo do conto é possível se deparar com provérbios como: “a manhã é mais sábia do que a noite (útro viétchera mudreniée - 104) ou "um conto é contado num ato, mas um ato é demorado” (skoro skázka skázyvaetsia, da ne skóro diélo diélatsia - 161). Ambos os provérbios também são considerados fórmulas temporais que servem para diminuir a velocidade da ação no conto. Segundo Dmítri Likhatchióv, pesquisador de literatura russa antiga, essas fórmulas são utilizadas quando se evidencia a distância entre a lentidão dos acontecimentos reais e a rapidez da narração. Ao utilizá-las, o contador parece querer se desculpar diante dos seus ouvintes/leitores, destacando a diferença irremediável entre a duração real dos acontecimentos e a da narração. Essas fórmulas destacam ainda o desejo de respeitar a unidade do tempo que reúne o tempo da interpretação e dos acontecimentos, unidade esta que não pode ser verdadeiramente obtida. $^{33}$

A entrada em cena de determinados personagens também é marcada por falas formulares. Assim, a Baba-Iagá revela-se, por uma típica frase, ao dialogar com um estranho que penetra na sua isbá:

Fu, fu! até hoje nunca se sentiu o cheiro de um russo ${ }^{34}$ por aqui, e eis que agora surge um e no meu nariz se atira $(F u$, fu! Dossiéleva rússkogo dúkha ne slykhát' býlo, a nýntche rússkii dúkh voótch'iu proiavliáetsia, $v$ nos brossáetsia. - 201)

\footnotetext{
${ }^{33}$ Likhatchov. D. Poétique historique de la littérature russe du X au XX siècle, 1988, p. 36.

${ }^{34}$ Personagens que desempenham o mesmo papel da Baba-Iagá ou que pertencem ao outro mundo (tov sviét) como o Koschiéi, o imortal, ou dragões, geralmente reconhecem o herói pelo seu cheiro de ser humano.
} 
Fu, fu! até hoje nunca se viu nem se sentiu o cheiro de um russo por aqui, e eis que agora surge um e na minha boca quer se atirar! (Fu, fu! Dossiéleva rússkogo dúkha vídom ne vídano, slýkhom ne slýkhano, a nýntche rússkii dúkh v vídu iavliáetsia, v ustá miétchetsia! -172).

Essa expressão geralmente é seguida por uma pergunta clássica da Iagá (ou outro personagem equivalente) ao herói: “E então, você está procurando uma tarefa ou fugindo de uma tarefa? (Tchto, diéla pytáech al ot diéla lytáech? - 204). Podemos citar ainda como situações formulares a frase do herói ao encontrar a isbazinha no meio da floresta e o momento de partida ou chegada da Baba-Iagá em seu pilão. Assim, têm-se:

Isbazinha, isbazinha! Fique de costas para a floresta e de frente para mim. (Izbúchka, izbúchka! Stan k liéssu zádom, ko mnié piéredom. - 235).

[...] saiu da floresta a Baba-Iagá, ela vinha no pilão, com o socador açoitava e com a vassoura apagava o seu rastro (... výekhala iz liéssu Baba-Iagá - v stúpe iédet, pestóm pogoniáet, pomelóm sliéd zametáet. - 104)

Vale observar ainda as frases referentes às qualidades como beleza, juventude, coragem de algum personagem ou objeto. Para se ressaltar tais atributos geralmente se usam as seguintes expressões:

[todos tão jovens, solteiros e valentes] que não dá para no conto contar nem com a pena anotar (... tctho ni v skázke skazát', ni peróm napissát' - 269) ou

[e ele era tão bom] que não dá para imaginar nem sonhar, só no conto contar (... tchto ni vzdúmat', ni vzgadát', tól'ko v skázke skazát' - 269)

Outro recurso do conto de magia são as constantes repetições de episódios inteiros. Com pequenas alterações de uma repetição para outra, elas geralmente ocorrem no número de três (triplicação), mas encontram-se também em quatro ou mais. O objetivo dessas repetições geralmente é intensificar a dificuldade das ações do herói. Assim, se num primeiro episódio, ele enfrentou um dragão de três cabeças, no segundo episódio, enfrentará um de seis, no terceiro, um de nove e assim por diante.

Os epítetos também merecem destaque. Marcados ou não pela rima, de personagens a elementos do cenário do conto ou objetos, praticamente todos dispõem de epítetos fixos, que revelam algum traço da sua natureza. Assim, temos: Baba-Iagá, perna de osso (Baba-Iagá, kostnáia nogá), Koschiéi, o imortal (Koschiéi 
Bessmiértnyi) ${ }^{35}$, Vassilíssa, a bela (Vassilíssa Prekrásnaia), Elena, a sábia (Elena Premúdraia), Ivan-tsarévitche, Ivan, o bobo (Ivan-durák), o lobo cinza (siéryi volk), a vasta planície (tchistoié póle), a densa floresta (dremútchii liés), o chapéu da invisibilidade (chápka-nevidímka), a bota de sete léguas (sapoguí-skorokhódy) etc.

Assim como seu estilo, o conto de magia possui personagens próprios, que não atuam em outros tipos de contos, como, por exemplo, os de costumes. Baba-Iagá, Koschiéi, Imortal, Vassilíssa, a bela, entre muitos outros, são figuras presentes somente no conto de magia.

Sobre o estilo do conto popular, de magia ou não, é importante ressaltar ainda a fundamental importância do papel dos narradores (homens e mulheres) na sua criação e desenvolvimento. O conto popular dispunha de verdadeiros especialistas na arte da sua interpretação. Dotados de ótima memória, a partir de alguns enredos, criavam diversos novos contos, ou seja, variantes. O tom que era dado ao conto também se modificava a partir da personalidade, das crenças, dos interesses, dos gostos do narrador. Assim, havia narradores que se dedicavam mais aos contos de magia, outros aos de costumes com intensa sátira, ou aos de animais. A escolha de palavras, a mistura de situações tradicionais com outras mais modernas como "morte por arma de fogo" ou ida a “grandes feiras”, a modificação de certos episódios, a ênfase ou a atenuação de certos detalhes, todas essas variações apontam as preferências e o tipo de narrador. Isso demonstra que embora os contos, em específico o de magia, guardem vestígios do passado, eles não deixam de ser frutos da imaginação dos seus contadores e até mesmo anotadores.

Muitos narradores gostavam de interpretar seus contos, dando viva expressividade principalmente à fala dos personagens, já outros misturavam aos contos traços de suas leituras de romances de aventuras ${ }^{36}$. Dispondo de todo um arsenal estilístico - fórmulas, repetições, epítetos, o desenrolar padrão das cenas - os narradores tinham as ferramentas necessárias para compor seus contos. Tais elementos, que em princípio poderiam ser vistos como geradores de monotonia no conto, criavam momentos de grande entretenimento. Os ouvintes se divertiam com o fato de já conhecerem trechos do conto e de esperarem pela interpretação que eles ganhariam na boca do narrador.

\footnotetext{
${ }^{35}$ Koschiéi, o imortal, é representado por um homem cadavérico ou mesmo por um esqueleto. Possuidor de muitas riquezas, sua especialidade é raptar mulheres, geralmente recuperadas pelo herói. Curioso mencionar que, embora imortal, a sua morte encontra-se em um carvalho, na ilha Buián, dentro de um baú, dentro do qual há uma lebre, dentro da qual há uma pata, dentro da qual há um ovo, dentro do qual há uma agulha que, ao ser quebrada, provoca a morte da criatura.

${ }^{36}$ Sokolóv, I. op. cit., p. 227.
} 
Esses intépretes não narravam apenas contos, mas outros vários gêneros populares como bilinas, lamentos etc. Eram geralmente muito respeitados em suas vilas, havendo pessoas que vinham de longe para assistir a suas interpretações, recebiam presentes e eram liberados do trabalho. ${ }^{37}$ Passaram a ganhar a atenção dos folcloristas com o advento do trabalho científico na coleta de obras populares, iniciado, nos meados do século XIX, com o trabalho de Afanássiev e amplamente desenvolvido nos anos posteriores. Assim, surgiram coletâneas que tinham seus textos divididos conforme o intérprete, fazendo com que muitos deles passassem a ser conhecidos pelo seu estilo.

\section{O estudo do conto de magia}

Dentre os diversos tipos de conto popular, é a respeito do conto de magia que se encontra a maior parte de estudos científicos. E a coletânea de contos populares, de Afanássiev, serviu amplamente de material para os pesquisadores do assunto. Dentre eles, destaca-se o tão conhecido e respeitado Vladímir Propp, que, em sua obra Morfologia do conto maravilhoso ${ }^{38}$, dedicou-se a decifrar a estrutura do conto de magia.

Essa obra de Propp foi lançada em 1928 e, embora ele seja considerado o responsável pelo mais bem elaborado trabalho nessa área, outros cientistas, contemporâneos ou não a ele, também já demonstravam preocupação com o assunto. Dentre eles, estavam:

A. N. Vesselóvski chegou a importantes conclusões sobre a composição do conto, sobre a distinção entre motivos e enredos [siujiét], entre elementos estáveis e variáveis, o que fez dele um antecessor de Propp ${ }^{39}$. Assim, como a Vesselóvksi, Propp faz menção no seu Morfologia a J. Bédier, lembrando que, embora de grande importância, seus estudos não obtiveram pleno sucesso na área morfológica ${ }^{40}$.

\footnotetext{
${ }^{37}$ Gruel-Apert, L. op. cit., p. 79.

${ }^{38}$ Vale aqui citar a esclarecedora observação de Boris Schnaiderman, no prefácio à edição brasileira dessa obra: "Tendo [Propp] trabalhado com cem contos de magia e muito cioso de frisar seu apego ao material empírico, sua cautela de não generalizar abruptamente as conclusões a outros campos, chamou a obra de Morfológuia volchébnoi skázki, isto é, 'Morfologia do conto de magia', mas editores no mundo inteiro têm os seus caprichos, e o livro saiu em 1928 com o título encurtado para Morfológuia skázki, que em português corresponde aproximadamente a 'Morfologia do conto maravilhoso'”. Propp, V. I. Morfologia do conto maravilhoso, 1984, p. 4.

${ }^{39}$ Gruel-Apert, L. op. cit., p. 120.

${ }^{40}$ Propp, V. I. Morfologia do conto maravilhoso, 1984, p. 21.
} 
Ainda, em 1928, Nikíforov apresenta a idéia de que os personagens do conto não são elementos estáveis, modificando-se de acordo com as variantes de um mesmo conto, ao mesmo tempo considera como elementos constantes as funções desempenhadas pelos personagens. Nikíforov afirma ainda que o número de funções desempenhadas pelos personagens é limitado ${ }^{41}$. Essas idéias muito se aproximavam das concepções de Propp.

Em sua abordagem morfológica, por meio da análise de cerca de cem contos de magia da coletânea de Afanássiev, Propp busca a definição do conto de magia a partir da sua estrutura, distinguindo no conto elementos estáveis e variáveis. Na primeira categoria estão as funções - isto é, ações responsáveis pelo desenvolvimento do conto, no total são 31 funções que podem estar todas presentes ou não no conto - e as esferas de ação dos personagens, ou seja, os papéis dos personagens.

Assim, Propp define sete esferas de ação - antagonista (ou malfeitor), doador (ou provedor), auxiliar, princesa (personagem procurado) e seu pai, mandante, herói e falso herói, e afirma que "a nomenclatura e os atributos dos personagens são elementos variáveis do conto" 42 , sendo atributos “o conjunto das qualidades externas dos personagens: idade, sexo, situação, aspecto exterior com suas particularidades, etc. ${ }^{43}$,

$\mathrm{O}$ autor lembra que os atributos e nomes dados aos personagens são um dos elementos responsáveis por todo o encanto e beleza presentes no conto, porém lembra ainda que eles são facilmente substituíveis, sendo que no papel de malfeitor podem estar um dragão, uma bruxa, uma princesa malvada etc. Isso pode ser observado na seleção de contos traduzidos neste trabalho. Por exemplo, o conto "Ivachko e a bruxa” (111) faz parte de uma série de variantes (108-111) onde o papel da Baba-Iagá é desempenhado ora por ela ora por uma bruxa (viédma) ou ainda na série do conto "Conto sobre o jovem valente, as maçãs da juventude e a água da vida” (172), cujas variantes (171-178) apresentam na função geralmente desempenhada pela Iagá uma bruxa ou um velhinho.

Como definição morfológica do conto de magia, Propp obteve a seguinte conclusão:

Do ponto de vista morfológico, podemos chamar de conto de magia a todo desenvolvimento narrativo que, partindo de um dano ou carência e passando por funções intermediárias, termina com o casamento ou outras funções utilizadas como desenlace. A função final pode ser a recompensa, a

\footnotetext{
${ }^{41}$ Sokolóv, op. cit., p. 241.

${ }^{42}$ Propp, V. I. Morfologia..., p. 81.

${ }^{43}$ Ibidem.
} 
obtenção do objeto procurado ou, de modo geral, a reparação do dano, o salvamento da perseguição, etc. ${ }^{44}$

Apesar de todo o mérito do livro, considerado o verdadeiro trabalho iniciador da análise morfológica do conto de magia, ele começa a ser divulgado no Ocidente somente a partir da década de 1960 .

Após a conclusão dessa obra, Propp se propõe ao estudo genético do conto, tal pesquisa resultaria na fundamental obra Raízes históricas do conto maravilhoso ${ }^{45}$. Para Propp, um estudo completo do conto deveria ser iniciado com a análise morfológica para que assim fosse possível em seguida encontrar uma explicação histórica para sua uniformidade. Assim, o autor se expressa no capítulo inicial do seu Morfologia:

Por enquanto, não falaremos do estudo histórico dos contos maravilhosos [skázka] e nos limitaremos à sua descrição, porque falar da gênese sem dar uma atenção especial ao problema da descrição, como geralmente costuma ser feito, é completamente inútil. É evidente que, antes de elucidar a questão da origem do conto maravilhoso, deve-se saber em primeiro lugar o que é conto. ${ }^{46}$

Ou ainda: “... afirmamos que enquanto não existir uma elaboração morfológica correta [sobre o conto] não poderá haver uma elaboração histórica correta. ${ }^{47,}$

Assim, observa-se como era clara a idéia de Propp realizar um completo estudo do conto de magia, no qual via "traços do paganismo mais antigo, dos costumes e ritos da antiguidade. $^{48 ”}$ E como resultado desse esforço, em 1946, é lançado Raízes históricas do conto maravilhoso, um estudo diacrônico (histórico-genético) precedido por uma descrição sincrônica presente no Morfologia. Nessa segunda etapa da pesquisa, "as funções recebem uma interpretação etnográfica (no plano genético). ${ }^{49}$ " No material folclórico e etnográfico de consulta, novamente estão presentes os contos de magia da coleção de Afanássiev, mas também contos pertencentes a outras renomadas coletâneas como as de Azadóvksi, Zeliénin, Ontchukóv, Khudiakóv etc. Comparações com contos de magia de outros países também fazem parte do estudo. Além disso, Propp faz uso dos trabalhos, entre outros, de Lévy-Bruhl, Franz Boas, James Frazer, referentes às áreas de antropologia, folclore, mitologia.

\footnotetext{
${ }^{44}$ Idem, p. 85.

${ }^{45}$ No original Istorítcheskie kórni volchiébnoi skázki: Raízes históricas do conto de magia.

${ }^{46}$ Propp, V. I. Morfologia, p. 14.

${ }^{47}$ Idem, p. 23.

${ }^{48}$ Idem, p. 81.

${ }^{49}$ Meletínski, E. M. O estudo tipológico-estrutural do conto maravilhoso in Propp, V. I. Morfologia do conto maravilhoso, p. 154.
} 
Nessa obra - cujas primeiras páginas dedicadas às Premissas (capítulo 1) estão, curiosamente para os nossos dias, recheadas de frases de Marx, Engels e Lênin usadas para justificar as escolhas científicas do autor - Propp afirma ter como objetivo realizar a análise “das imagens e dos motivos fundamentais do conto" 50 . O autor menciona que os motivos do conto acham-se estreitamente ligados e que nenhum deles pode ser compreendido isoladamente, aconselha, assim, ao leitor a ler essa obra na sua seqüência natural, e não iniciá-la por qualquer parte ${ }^{51}$. O tipo de análise empregada seria a análise genética, elucidando "as fontes do conto maravilhoso [volchiébnaia skázka, conto de magia] na realidade histórica ${ }^{52 ”}$. Diferencia seu trabalho do realizado pela escola histórica, encabeçada por Vsiévolod Miller, dizendo que, ao contrário desta, não pretende ligar os motivos do conto a um acontecimento histórico, mas sim a um fenômeno do passado histórico. Aos poucos, o autor demonstra sua linha de pensamento marxista, considerando que o conto deve ser confrontado, num primeiro momento, com um determinado sistema de produção e mais precisamente com as instituições presentes nesse sistema. E explica: "não podemos comparar o conto com o sistema tribal, mas podemos comparar determinados motivos do conto com as instituições do sistema tribal” ${ }^{33}$. Partindo da premissa que o conto conservou vestígios de antigas instituições sociais e que o rito é uma expressão concreta (atos e ações) de significado mágico de determinadas instituições, Propp considera como fonte primária dos motivos do conto de magia o rito ${ }^{54}$.

De qualquer forma, o conto não é uma correspondência direta do rito, podendo ser na realidade uma reinterpretação dele, ou seja, as não-correspondências diretas entre rito e conto podem ser explicadas pelo fato que algum elemento tenha se modificado no conto, por ter se tornado inútil ou não mais aceito em um novo contexto histórico. ${ }^{55} \mathrm{O}$ autor lembra ainda que embora, via de regra, o rito sirva como explicação para um motivo correspondente no conto, pode ocorrer também o contrário, o rito já estar tão pouco conservado, que o conto representa a sua explicação e não vice-versa ${ }^{56}$.

Para Propp, o rito-chave para a compreensão do conto é o de iniciação. Além disso, enfatiza “o importante papel que desempenham as concepções do além, as

\footnotetext{
${ }^{50}$ Propp, V. I. Raízes históricas do conto maravilhoso, 1997, p. XXII.

${ }^{51}$ Ibidem.

${ }^{52}$ Propp, V. I. Raízes históricas..., p. 2.

53 Idem, p. 8.

${ }^{54}$ Idem, XII, 437 e ss.

${ }^{55}$ Idem, p. 11.

${ }^{56}$ Idem, p. 15.
} 
peregrinações para o outro mundo" ${ }^{57}$ como fonte para o maior número de motivos. A cada uma dessa fontes, chama de ciclos. Assim, afirma que embora seja difícil traçar um limite claro entre o ciclo da iniciação e o ciclo das concepções de morte, é sabido que todo rito de iniciação era tido como uma estada no país da morte e que, reciprocamente, “o morto passava por tudo o que passava o neófito: recebia um auxiliar, encontrava um engolidor, etc. ${ }^{58 \text { " }}$

Em busca por uma realidade histórica que explicasse os motivos composicionais do conto, Propp prossegue sua análise relacionando-o com o mito. Ao entender mito como narrativas sagradas que convivem com o ritual, sendo contadas ou encenadas durante o seu acontecimento ${ }^{59}$, ou seja, tendo “uma ligação viva com toda a realidade do povo, com sua produção, organização social e crenças” ${ }^{\circ 0}$, Propp acredita que, a partir do momento que os povos executores desses rituais tiveram seus modos de produção modificados, ${ }^{61}$ essas narrativas sagradas perderam o seu valor, transformando-se em narrativas puramente artísticas e de utilização estética, sendo as novas condições de vida responsáveis por superposições de camadas, substituições e reinterpretações do que antes havia no mito. Esse fenômeno não deve levar a um desmerecimento do conto, Propp assim ressalta:

... o conto, que perdeu suas funções religiosas, não é em si mesmo alguma coisa inferior ao mito do qual se origina. Ao contrário, liberto dos laços do convencionalismo religioso, movido agora por outros fatores sociais, ele irrompe no espaço livre da criação artística... ${ }^{62}$

À transformação da narrativa sagrada em uma narrativa não espiritual, mas sim artística, Propp deu o nome de profanação. Sendo esse o momento de nascimento do conto.

A origem dos contos de animais também recebeu a atenção de Propp. Lembrando que o rito de iniciação não era o único e acreditando que outros tipos de contos tenham tido a mesma origem ritualística, o cientista relaciona os contos de animais com ritos sazonais de caça e de trabalhos agrícolas e seus respectivos mitos de origem (originmyth $)^{63}$.

\footnotetext{
${ }^{57}$ Idem, p. 437.

${ }^{58}$ Idem, p. 438.

${ }^{59}$ Idem, p. 441.

${ }^{60}$ Idem, p. 443.

${ }^{61}$ Idem, p. 439.

62 Idem, p. 444.

${ }^{63}$ Idem, p. 446.
} 
Outro renomado estudioso que se ateve à origem do conto popular foi E. M. Meletínski (1918-2005). Contemporâneo a Propp e conhecedor profundo de seus trabalhos, Meletínski constata a origem do conto no mito, assim como já fizera Propp. Porém, não concorda que se deva generalizar que a origem do conto se encontra no rito. Assim diz:

Já observamos várias vezes que o enredo do mito não remonta obrigatoriamente ao ritual e que nas culturas mais arcaicas existem mitos "não rituais" assim como rituais "amíticos". Entretanto, para os mitos que apresentam base ritual ou estão estreitamente entrelaçados com os rituais (sendo partes componentes ou comentário obrigatório a eles), o rompimento da ligação imediata com a vida ritual da tribo é, sem dúvida, uma importante premissa para a transformação do mito em conto maravilhoso ${ }^{64}$.

Para Meletínski, as principais fases que constituem a transformação do mito em conto são:

[...] a desritualização e dessacralização, o debilitamento da fé rigorosa na autenticidade dos "acontecimentos" míticos, o desenvolvimento da invenção consciente, a perda da concretitude [sic] etnográfica, a substituição dos heróis míticos por homens comuns, do tempo mítico pelo tempo fabular indefinido, o enfraquecimento ou a perda do etiologismo, o deslocamento da atenção dos destinos coletivos para os individuais e dos cósmicos para os sociais ${ }^{65}$.

Meletínski aponta as fórmulas tradicionais do conto como traços resultantes da transformação do mito em conto, mais especificamente "da desmitologização do tempo da ação, da substituição do tempo da criação primordial [...] por um tempo 'fabular’ indefinido ${ }^{66,}$. Assim, ao perder o seu sentido etiológico, o enredo do mito recebe fórmulas que indicam a inautenticidade da narrativa e a indefinição do tempo e do lugar.

No entanto, ambos os pesquisadores são uníssonos ao exprimirem o fato de o conto ser uma literatura artística, ficcional. Meletínski, que muito se dedicou ao estudo do herói do conto popular de magia ${ }^{67}$, apontava enfaticamente o papel do herói do conto em oposição ao do herói do mito. Enquanto no mito, o herói tem papel de demiurgo, sendo herói cultural, raptando a água ou o fogo e “criando pela primeira vez a água

\footnotetext{
${ }^{64}$ Meletínski, E. M. A poética do mito, 1987, p. 310.

${ }^{65}$ Idem, p. 309.

${ }^{66}$ Idem, p. 311.

${ }^{67}$ Sobre esse assunto consultar Meletínski, E. M. Guerói volchiébnoi skázki (O herói do conto de magia).
} 
potável como elemento do cosmo” ${ }^{68}$; no conto, a trajetória do herói está fortemente ligada com o seu destino pessoal, os objetos e fins a serem atingidos são responsáveis pelo seu bem-estar ou de seus próximos, a água conseguida pelo herói do conto geralmente é em benefício do seu pai.

\title{
A imagem da Baba-Iagá e seu entorno
}

\begin{abstract}
Os bielo-russos acreditam que a Morte entrega os defuntos para a Baba-Iagá, e juntas viajam pelo nosso mundo, e que a Baba-Iagá e as bruxas subordinadas a ela alimentam-se das almas dos mortos, tornando-se tão leves quanto as próprias almas: essa é uma crença muito notável! Contam também que a Baba-Iagá rouba crianças, as leva para os ares e as lança de lá já mortas sobre o telhado das suas casas.
\end{abstract}

Afanássiev ${ }^{69}$

Ao identificar a origem de diversos motivos do conto de magia, Propp compõe um trabalho detalhado sobre os motivos referentes ao personagem da Baba-Iagá. Os estudos sobre esse personagem são escassos, e o material oferecido por Propp traz importantes informações, embora longe de resolver todas as questões - já que é sabido por todos e reconhecido pelo próprio autor que “a Baba-Iagá é um personagem muito difícil de ser analisado, pois sua imagem se compõe de uma série de detalhes. Esses detalhes, agrupados a partir de contos diversos, às vezes são divergentes, incompatíveis, não se fundem numa imagem indivisa." 70

Assim, no capítulo “A floresta encantada”, mantendo a sua abordagem histórica, Propp esclarece alguns motivos relacionados à Iagá e à sua imagem. De modo geral, reconhece no conto três tipos de Iagá: a Iagá doadora, a Iagá raptora e a Iagá guerreira. Essas categorias não restringem o personagem a uma única esfera de ação nem se restringem à figura da Iagá. Por exemplo, como doadora há geralmente uma coincidência entre seu tipo e a esfera da sua ação, porém, o tipo guerreira pode, por vezes, acumular os papéis de antagonista (luta com o herói) e auxiliar, ainda que involuntário (indica-lhe o caminho a outro mundo). Isso porque um único personagem pode ocupar várias esferas de ação ${ }^{71}$.

Vale lembrar que os papéis não são distribuídos com exclusividade para determinados personagens. Assim, no papel de doador e antagonista podem estar muitos

\footnotetext{
${ }^{68}$ Meletínski, E. M. A poética do mito, 1987, p. 312.

${ }^{69}$ Afanássiev, A. N. Mitologia da Rússia antiga (Mifológuia driévnei Russi), 2005, p. 572.

${ }^{70}$ Propp. V. I. Raízes históricas..., p. 50.

${ }^{71}$ Propp. V. I. Morfologia... p. 74.
} 
outros personagens além da Iagá. Porém, classicamente, a Baba-Iagá está nos contos como doadora do meio mágico. Como raptora, também podemos encontrá-la com freqüência, já como guerreira são extremamente raros os casos, ao menos, na coleção de Afanássiev.

A diferença entre elas consiste essencialmente na forma como ocorre o momento do seu encontro com o herói ou heroína do conto. A doadora se caracteriza por já estar na sua isbá quando o herói chega. Ela então interroga o herói ou heroína que receberá dela um cavalo ou outros objetos mágicos ou conselhos que lhe serão úteis na sua jornada (172, 173, 201, 204, 235, 269 ${ }^{72}$ ), geralmente está deitada sobre a piétch, sobre um banco ou sobre o chão, ocupando toda a isbá (201, 204, 235, 269). A raptora é reconhecida por sair da isbá ou chegar à isbá montada em seu pilão, o qual é fustigado pelo socador, suas idas e vindas são ocasionadas pela sua busca por crianças (que representam o herói) para serem assadas e devoradas, o que é resolvido com a fuga e salvação do raptado $(106,111)$. A guerreira também não se encontra em casa, entra voando na isbá onde se encontram os heróis, corta-lhes uma tira das costas e os enfrenta fisicamente $^{73}(141,161)$.

O objetivo de Propp não é detalhar esses tipos, mas mostrar historicamente como a imagem da Iagá, qualquer que seja o seu tipo, está ligada ao rito de iniciação dos jovens no período da puberdade e ao reino dos mortos, uma vez que esse rito e as concepções da morte estão fortemente ligados.

A tomada do conto como reflexo do rito de iniciação já tinha sido apresentada por outros pesquisadores como Frazer, Saintyves, B. V. Kazanski, S. Ya, Lurie etc, de cujos trabalhos Propp tinha conhecimento e poder de análise.

A relação entre os motivos do conto e o rito de iniciação torna-se evidente, logo que Propp caracteriza o rito. Assim, explica o autor:

O que é a iniciação? É uma instituição própria do regime tribal. Esse rito ocorria no momento da puberdade. Ao cumpri-lo, o jovem era introduzido na sociedade tribal, da qual se tornava membro investido de plenos direitos, ao mesmo tempo que adquiria o direito de se casar. Essa era a função social do rito. [...] Acreditava-se que durante o rito o rapaz morria e ressuscitava como um novo homem. É a chamada morte momentânea. A morte e a ressurreição eram provocadas por ações que representavam a deglutição da criança por um animal monstruoso que a devorava. [...] Para a realização desse rito construíam-se às vezes casas ou cabanas especiais, com a forma

\footnotetext{
${ }^{72}$ Números de alguns dos contos da seleção aqui traduzida que apresentam essas características.

${ }^{73}$ Propp, V. I. Raízes históricas..., p. 50 e 71.
} 
de um animal e com uma porta representando a bocarra. Ali era feita a circuncisão. O rito ocorria sempre na parte mais densa da floresta ou de uma moita, e no maior sigilo. Era acompanhado de torturas e sevícias físicas (dedos cortados, dentes arrancados, etc.). Outra forma de morte momentânea expressava-se no fato de o rapaz ser simbolicamente queimado, cozido, assado, cortado em pedaços e depois ressuscitado. [...] Transmitiam-lhe técnicas de caça, segredos religiosos, conhecimentos históricos, regras e normas da vida social, etc. [...].

São essas, esquematicamente, as características básicas do rito. ${ }^{74}$

A partir dessa descrição, os trechos do conto de magia onde há a presença da Baba-Iagá, seja qual for o seu tipo, e todo o seu entorno, parecem de alguma forma elucidados. Dentre os elementos que fazem parte do seu entorno, um de grande importância é a floresta. É nesse lugar, sempre caracterizado como um lugar de mata densa, ermo, distante, que o herói ou a heroína do conto de magia acabam parando no decorrer do conto. A relação entre a floresta do conto e do rito mostra-se evidente, "a floresta do conto reflete a lembrança da floresta como local do rito e como entrada para o reino dos mortos” ${ }^{75}$. Nas profundezas dessa floresta impenetrável, localiza-se a isbazinha sobre pernas de galinha, ligada automaticamente à cabana onde eram realizados os rituais, cabanas estas que por vezes possuíam “acentuadas características zoomórficas $^{76,}$. No conto, ao encontrá-la, o herói não tem como contorná-la e precisa passar por ela para seguir seu caminho, entretanto, ela se localiza de costas para ele. Para Propp, o fato de a entrada da isbá estar ao contrário representa que sua entrada está voltada para o reino dos confins (tridiéciatoe tsárstvo, trigésimo reino); dessa forma a isbá é tida como uma fronteira entre dois mundos, na qual o herói só consegue penetrar após pronunciar as palavras certas, das quais ele naturalmente é conhecedor: "Isbazinha, isbazinha! Fique de costas para a floresta e de frente para mim.” Segundo Propp, durante o rito "supunha-se que através da cabana o candidato descia até o reino da morte. Essa é a razão pela qual a cabana caracteriza-se como passagem para o outro mundo" ${ }^{77}$.

Dentro da isbá, o herói encontra a Baba-Iagá tida então como guardiã da passagem para o outro mundo. Ao sentir a presença do herói na sua casa, diz: "Fu, fu! até hoje nunca se viu nem se sentiu o cheiro de um russo por aqui, e eis que agora surge um e na minha boca quer se atirar” (172). Segundo Propp, frases desse tipo revelam a

\footnotetext{
${ }^{74}$ Idem, p. 54.

${ }^{75}$ Idem, p. 57.

${ }^{76}$ Idem, p. 61.

${ }^{77}$ Idem, p. 64.
} 
ligação da Iagá com o mundo dos mortos, para os quais o cheiro humano é extremamente desagradável, o cheiro do herói aponta a presença de um ser vivo que tenta entrar no reino dos mortos.

O fato de a Iagá logo em seguida questionar o herói sobre o porquê da sua vinda tem como resposta deste a recusa em falar antes de ser alimentado. Baseado em materiais sobre os rituais de culto aos mortos, nos quais se constata que o morto "deve

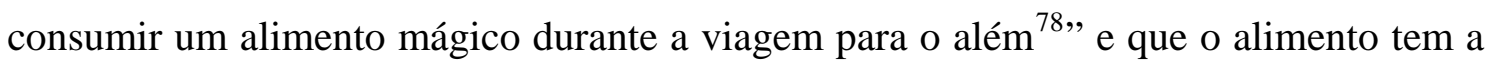
função de abrir a boca do morto, transformando-o em espírito, sendo que somente depois de comer ele pode falar ${ }^{79}$, Propp relaciona esse fato à recusa do herói em falar antes de ser alimentado. O estudioso aponta essa reação como uma prova de que o herói não teme esse alimento (alimento do mundo dos mortos), tendo direito a ele, sendo assim autêntico em oposição a um possível falso herói, fato que acalma a Iagá, que logo o atende ${ }^{80}$. Acompanhado do pedido de se alimentar e beber, por vezes, o herói menciona também o desejo de se banhar. Como uma possível origem para isso, Propp cita o fato de que em alguns mitos tribais estritamente ligados ao rito de iniciação, o herói se lava várias vezes para eliminar seu próprio cheiro ${ }^{81}$.

Diversos detalhes da imagem da Iagá ou a forma como ela se apresenta ligam sua figura à de um defunto. Para Propp, o fato de ela, em alguns contos, ocupar toda a isbá, explica-se não porque ela seja enorme, mas sim porque sua isbá é pequena, fazendo com que ela se assemelhe a um cadáver, “um cadáver em um caixão apertado ou em um cubículo especial onde se enterram os mortos ou se deixam os moribundos para que acabem de morrer. Ela é um morto. Outros pesquisadores já a viram como um cadáver”82. Outro traço que reafirma essa idéia é a sua consagrada perna de osso, um indício de decomposição. Porém Propp explica que a perna de osso está relacionada ao fenômeno de antropomorfização do personagem, um evento $\operatorname{tardio}^{83}$, já que nos arcaicos materiais ameríndios estudados por ele, o reino dos mortos é protegido sempre por um animal ou por uma velha sem traços de putrefação, e em contos da província de Viátka, coletados por Zeliénin, onde se conservam traços arcaicos, o papel da Iagá era desempenhado por um bode. De qualquer forma, a perna de osso explica ainda o fato de

\footnotetext{
${ }^{78}$ Idem, p. 70.

${ }^{79}$ Idem, p. 68-69.

${ }^{80}$ Idem, p. 68.

${ }^{81}$ Idem, p. 67.

${ }^{82}$ Idem, p. 71.

${ }^{83}$ Idem, p. 71.
} 
a Iagá, como um morto, não andar, mas sim voar, deslocando-se no seu pilão, e de estar deitada na sua isbá como um cadáver ${ }^{84}$.

E assim, muitos outros motivos relacionados à Iagá são detalhadamente expostos por Propp na sua ligação direta com os ritos.

Por fim, o estudioso conclui que a imagem da Baba-Iagá corresponderia ao personagem ou à máscara que dirigia o rito de iniciação. Considerando que uma forma arcaica da Iagá seria sua representação animal (alguns contos apresentam no papel de Iagá animais como bode, urso etc.), Propp explica: “O grande mestre e ancestral que dirige o rito freqüentemente era representado na forma de um animal, cuja máscara ele usava” ${ }^{85}$. Sobre a questão por que seria a Iagá uma figura feminina, já que o rito era executado por homens, o que explica também a presença do equivalente masculino da Iagá em alguns contos, Propp apresenta diversas possibilidades, dentre as quais, o travestismo de homens em mulheres como apontam testemunhos etnográficos. ${ }^{86}$ Para Propp: “O mestre que vive na floresta é histórico, já a mulher, a mãe, a velha, a dona da casa, a doadora dos poderes mágicos, é pré-histórica, é extremamente arcaica, mas podemos encontrar vestígios dela nos materiais do rito.” ${ }^{87}$

De maneira geral, uma das imagens mais conhecidas da Baba-Iagá e de todo o seu entorno talvez seja a representada no famoso conto "Vassilíssa, a bela” (104). Nele, a Iagá é uma criatura antropomorfizada em uma velha aterrorizante, que vive nos ermos da floresta, viaja dentro de seu pilão, açoitando-o com o socador e apagando seu rastro com uma vassoura, à sua chegada, as árvores trepidam, as folhas secas estalam. Sua isbazinha, embora nesse conto não seja descrita sobre pernas de galinha, é narrada de maneira detalhada: “a cerca ao redor da isbá era feita de ossos humanos, na cerca estavam fincados crânios humanos com olhos; em vez de batentes no portão: pernas humanas; em vez de ferrolho: braços; em vez de fechadura: uma boca com dentes afiados.” Ainda nesse conto, embora se tenha uma Iagá doadora, ela não se encontra em casa no momento da chegada da heroína. Vale lembrar que nos comentários à edição de Contos populares russos, de 1957, organizada por Propp, menciona-se que esse conto passou por modificações literárias. De qualquer forma, ele é um bom exemplo da diferença existente no encontro entre a Iagá e um herói e a Iagá e uma heroína. Geralmente, ao adentrar à isbá da Iagá, o herói não é submetido a penosas tarefas, já a

\footnotetext{
${ }^{84}$ Idem, p. 72.

${ }^{85}$ Idem, p. 119.

${ }^{86}$ Idem, p. 121.

${ }^{87}$ Idem, p. 123.
} 
heroína precisa realizar muitos trabalhos, os quais são completados com o auxílio de ajudantes mágicos (antes ou durante conquistados). Segundo Propp:

... a Iagá é um personagem de quem é típico propor provas difíceis. Isso é verdade apenas nos contos de personagens femininas, mas pode-se demonstrar que tais provas são basicamente de origem tardia. É menos comum que um homem seja submetido a provas: na verdade elas são muito raras e pouco variadas. Geralmente a recompensa vem imediatamente após o diálogo: "Dificilmente conseguirás! Só se eu ajudar-te!, e ela lhe deu o cavalo (Af. 174) ${ }^{88}$.

No entanto, a incontável quantidade de variantes de contos de magia mostra-nos que sempre há exceções e aqui mesmo na seleção de contos traduzidos neste trabalho temos uma. O conto “A pena de Finíst, o falcão brilhante” (235) mostra uma heroína que não é submetida a tarefas difíceis, colocando-se na mesma posição de um herói masculino, que geralmente desenvolve o papel de herói buscador. Em oposição a esse tipo de herói, Propp apresenta o herói vítima, representado, por exemplo, por uma jovem expulsa de casa pela qual ninguém parte à procura. ${ }^{89}$

\section{Outras observações sobre a Baba-Iagá}

A busca pela compreensão da origem da Baba-Iagá (ou Baba-Iagába, Ieguíbikha, Egui-Babá, Baba-Iaziá, Iagá-Baba, Iagáia, Iagávaia, Iaguíchna, Iaguínitchna) há muito atrai a atenção de estudiosos. Como uma das primeiras fontes escritas sobre a BabaIagá, tem-se a obra Sobre o estado russo (1591), de G. Fletcher ${ }^{90}$. Em um capítulo dedicado a alguns povos do Norte e Nordeste da Rússia, o autor diz:

Em relação às narrações sobre a Zolotáia Baba ${ }^{91}$ ou Iagá-Baba - sobre a qual li em algumas descrições desta região, que ela é um ídolo na forma de

\footnotetext{
${ }^{88}$ Idem, p. 83.

${ }^{89}$ Propp, V. I. Morfologia..., p. 41.

${ }^{90}$ D. Fletcher (1548? - 1611). Escritor e diplomata inglês, após uma estada com objetivos comerciais, em 1588, na Rússia, escreveu Sobre o estado russo, editado pela primeira vez na Inglaterra em 1591. Nessa obra, descreve a vida russa no século XVI, narrando sobre o regime estatal, a estrutura econômica, rituais religiosos e o cotidiano de várias camadas sociais. Uma edição russa foi publicada em 1906.

${ }^{91}$ A Zolotáia Baba, literalmente, mulher de ouro, já havia sido citada na obra de outros pesquisadores, dentre os quais, Sigmund Herberstein (1486 - 1566), um barão alemão, diplomata e viajante, que, após diversas visitas à Rússia ocasionadas por motivos profissionais, escreveu a obra Notas sobre assuntos moscovitas, publicada em 1549, na qual diz: “A Baba de Ouro, ou seja, a Velha de Ouro, é um ídolo posto nas margens da foz do Obe [rio da Sibéria], na região de Obdor. Às margens do Obe e dos rios vizinhos localizam-se por todos os lados muitas fortalezas cujos senhores, como falam, são todos súditos do soberano moscovita. Contam, melhor dizendo corre uma história, que o ídolo da Velha de Ouro é uma
} 
velha, que dá às perguntas do sacerdote respostas proféticas sobre o sucesso de empreitadas e sobre o futuro - eu estou convencido que é uma história sem fundamentos. ${ }^{92}$

A origem da palavra iagá também foi objeto de pesquisa. O etnógrafo N. A. Abrámov $^{93}$ relacionou, em seu livro Descrição sobre a região de Beriózovski (1857), o nome iagá a um regionalismo siberiano para designar um tipo de casaco de pele, ou, às vezes, de pena, que tinha como peculiaridade apresentar esses materiais do lado de fora da roupa. Cita ainda o termo iagúchka como um tipo de iagá, especificamente usada por mulheres durante viagens, enquanto a primeira seria usada por qualquer pessoa. Definição muito semelhante é dada por V. Dal em seu dicionário.

Uma outra hipótese que relaciona esse significado do nome iagá à formação da imagem do personagem, como um cadáver que habita uma isbazinha sobre pernas de galinha nos ermos da floresta, está vinculada a um ritual fúnebre de terras siberianas, no qual bonequinhas (ittarmas), vestidas com os casacos de peles típicos da região (iagui), eram colocadas dentro de isbazinhas postas sobre pilares, evitando assim a entrada de animais selvagens. No interior dessas bonecas, segundo a crença popular, alojava-se a alma do morto. ${ }^{94}$

O nosso conhecido Afanássiev também se dedicou ao estudo da interpretação da simbologia existente na figura da Baba-Iagá no conto popular. Em Concepções poéticas dos eslavos sobre a natureza (1866-1869), o estudioso, fundamentando-se nas teorias pertencentes à escola mitológica, conclui:

Os bielo-russos acreditam que a Baba-Iagá viaja pelos céus em um pilão de fogo e o açoita com uma vassoura de fogo, que durante a sua viagem, os ventos uivam, a terra geme, as árvores seculares estralam e se curvam. Tanto o pilão quanto a isbazinha que se move [...] são metáforas das nuvens de tempestade, e o socador ou o cajado são metáforas da clava de Perun ${ }^{95}$

estátua na forma de uma velha que segura no colo um filho, sendo visível ainda uma criança, que dizem ser o seu neto. Além disso, dizem que ela colocou lá certos instrumentos musicais, semelhantes a cornetas, que produzem um som constante. Se isso realmente acontece, então, suponho que a origem do som esteja no constante e forte vento que sopra nesses instrumentos. (http://www.vostlit.info/Texts/rus8/Gerberstein/text6.phtml)

92 Fletcher, D. Sobre o estado russo $(O$ gossudárstve rússkom). Disponível em $<$ http://www.vostlit.info/Texts/rus4/Fletcher/frametext4.htm>

${ }^{93}$ Nikolái Aleksiéevitch Abrámov (1812 - 1870), etnógrafo especialista em Sibéria e Ásia Central. Notase que, assim como em Fletcher, são descrições de povos da Sibéria.

${ }_{94}^{94}$ Ivanov, A. História, apenas um formato (Istória - tólko formát), Nezavíssimaia, s/p. e Siázi, A. M. Nossa vida (Nacha jisn), s/p.

${ }^{95}$ Na mitologia indo-européia e russa, deus do trovão e da tempestade. Nos séculos IX e X, Perun, um dos principais deuses do panteão pagão russo, era tido como protetor dos príncipes russos e dos seus exércitos. 
[...] Indo atrás dos heróis do conto, que fogem da raiva e vingança da Iagá, ela os persegue na forma de nuvem negra. ${ }^{96}$

Na mesma obra, o autor ainda aponta semelhanças entre a Iagá e personagens de contos gregos, albaneses e búlgaros, nos quais o equivalente a ela, respectivamente, seria representado por uma lâmia ${ }^{97}$, uma dragoa e uma serpente.

Assim, observa-se a intensa variedade de interpretações sobre a Baba-Iagá e tudo o que lhe diz respeito. No que se refere à imagem da isbazinha sobre pernas de galinha, apresentamos ainda a idéia defendida pela docente em mitologia Aleksandra Barkova ${ }^{98}$, que relaciona a locução na kúr’ikh nójkakh (sobre pernas de galinha) como uma modificação proveniente do adjetivo kurnói, algo impregnado de fumaça, alegando ser uma menção aos pilares, que eram defumados, sobre os quais se colocavam isbazinhas que armazenavam restos mortais. Outros estudos relacionam a imagem da isbazinha simplesmente a casinhas construídas sobre dois ou três pilares no meio da floresta com a função de armazenar munições e víveres para uma caminhante ocasional, um caçador etc.

O conceituado folclorista contemporâneo Kiríll Tchistóv (1919 - ), em um artigo dedicado à figura e personagem da Baba-Iagá, também propõe uma explicação para o seu nome:

O nome da Baba-Iagá, tanto do ponto de vista das línguas literárias dos eslavos do leste quanto dos dialetos populares, é dificilmente explicado, não existindo um contexto léxico ou um campo semântico semelhante. Por outro lado, ele pode ser facilmente explicado a partir da comparação com os lexemas parentais em outras línguas eslavas. "Iagá” (variantes nos contos russos, ucranianos e bielo-russos - Egá, Igá, Iagáia, Iugá, Baba-Iaziá etc.) tem suas raízes no proto-eslavo *ega/esa, que tem parentesco com o lituano engti ou o letão igt com o sentido geral de mal, pesadelo, doença, bruxa etc. ${ }^{99}$

Nesse artigo, Tchistóv ressalta ainda a importância de se lembrar que a Baba-Iagá, assim como outros personagens (Koschiéi, o imortal ou Zmei Gorýnytch), é um personagem exclusivo do conto popular (skázka). Nem ela nem os outros citados figuram nas narrativas que expressam as crenças tradicionais populares, onde estão presentes criaturas como liéchi (espírito da floresta), vodianói (espírito da água), domovói (espírito doméstico), bánnik (espírito da bánia) etc. O contrário também é

\footnotetext{
${ }^{96}$ Afanássiev, A. N. Concepções poéticas..., p. 572.

${ }^{97}$ Monstro mítico com cabeça de mulher e corpo de serpente que se alimentava de homens e crianças. (Dicionário eletrônico Houaiss).

${ }^{98}$ Barkova, A. L. Antigas crenças eslavas (Verovániia driévnikh slavián), s/p.

${ }^{99}$ Tchistóv, K. V. Baba-Iagá, Jiváia stariná, 1997, n. 2 (14), s/p.
} 
verdadeiro, essas criaturas não figuram nos contos populares. Como causa, o autor explica:

[...] o conto popular russo, enraizado na consciência mitológica arcaica, há muito perdeu as ligações diretas com essa consciência, dessacralizou-se, desmitologizou-se, representando em si uma manifestação profana com nítida função estética. ${ }^{100}$

Essa idéia de dessacralização já havia sido mencionada por P. G. Bogatyrióv, em 1929, que via o conto popular, inclusive o russo, como uma manifestação que germina no solo mitológico, mas que o supera, destacando-se dele histórica e funcionalmente. Tal concepção foi muito desenvolvida por Propp e Meletínski, diferenciando-os claramente dos adeptos das teorias mitológicas do século XIX ${ }^{101}$.

Diversos pesquisadores do conto popular russo já se dedicaram às complexas e polêmicas questões sobre a figura da Baba-Iagá: sua origem, funções, significados etc. Cada um a seu modo trouxe importantes contribuições. No entanto, os trabalhos desenvolvidos por Propp podem ser considerados os que melhor apresentam os fundadores e fundamentais conceitos sobre o conto popular russo, sobretudo o de magia, e a imagem da Baba-Iagá. Não há estudos sobre esse assunto que não revelem a importância de Propp.

\footnotetext{
${ }^{100}$ Idem, s/p.

${ }^{101}$ Idem, s/p.
} 
PARTE II 


\section{Sobre a tradução}

A presente tradução, de alguns dos contos reunidos na sexta edição de Contos populares russos, de Afanássiev, teve como objetivo realizar uma breve amostra dos diferentes tipos do personagem Baba-Iagá apresentados por Propp em As raízes históricas do conto maravilhoso. Assim, temos onze contos populares de magia, sendo dois sobre a Baba-Iagá raptora; dois, sobre a guerreira e outros sete sobre a doadora.

Desses contos, ressaltamos serem totalmente inéditos em português, ou seja, nem mesmo traduzidos de forma indireta, os contos 111, 141, 172, 173, 204, 235 e 269.

Para que a tradução pudesse ser realizada, foi imprescindível a consulta a diversos dicionários, principalmente ao Dicionário da língua grã-russa viva, de V. Dal. Entre as dificuldades encontradas no texto, citamos a grande quantidade de palavras relacionadas à vida cotidiana campesina, cujos contextos e significados são muito distantes da realidade brasileira. Destacamos duas particularmente específicas da cultura russa: piétch - com tudo o que lhe diz respeito: seu funcionamento, seus utensílios, compartimentos, diversas funções (alimentar, aquecer, servir como dormitório) - e bánia, cujo funcionamento requer um preparo quase ritualístico, não se resumindo a um simples banho. Pela dificuldade em traduzir essas palavras, das quais a abrangência de sentidos não pode ser resumida em uma única palavra da língua portuguesa sem que haja omissão da amplitude de seus significados, optou-se por mantê-las transliteradas, acompanhadas de explicações encontradas no Glossário. Acreditamos que, com o passar do tempo, essas palavras possam ser dicionarizadas como foram tróica, samovar, balalaica, cnute, tsarévitche, tsarevna, tsar, isbá, bilina etc, assim presentes no Dicionário eletrônico Houaiss da língua portuguesa.

Além disso, outra questão problemática da tradução são as fórmulas: frases ou palavras que sempre acompanham determinado personagem ou ação. Em língua russa, o ritmo e a rima são seus elementos constantes, o que traz inevitável riqueza e graça à narração. Porém, nesta tradução esse traço não foi priorizado, enfatizando-se o sentido das expressões. Outro ponto a se observar é a repetição dessas fórmulas, geralmente por três vezes. Embora elas guardem o mesmo sentido, apresentam pequenas modificações de uma para a outra, o que muitas vezes passa despercebidamente nas traduções. Todos esses pequenos detalhes foram aqui mantidos. Isso ocorre, por exemplo, nas falas dos 
bogatyrí do conto “Os bogatyrí Medviédko, Ussýnia, Gorýnia e Dubýnia” (141), quando explicam o porquê de não terem conseguido preparar a refeição.

Por fim, as notas de rodapé explicativas têm o objetivo de aproximar o leitor do sentido original russo, apresentando expressões ou palavras, sempre que possível, dentro do seu contexto cultural. Assim, lembrando que a tradução envolve escolhas e interpretações, por meio das notas, o leitor pode fazer as suas próprias avaliações.

\section{Numeração dos contos traduzidos}

Apresenta-se abaixo o número do conto nesta tradução, seu número original, como consta nas edições russas, seguido de sua classificação AT (Índice de AarneThompson) e de informações sobre a coleta. Pelo fato de os contos de Afanássiev terem sido renumerados em suas reedições, costuma-se apresentar o número atual seguido do antigo. Assim, têm-se o número adotado a partir da quinta edição, empregado até os dias de hoje, e o seu anterior, usado da segunda à quarta edição.

1. $106 / 61 \mathrm{a} \quad 327 \mathrm{C}$

Texto anotado na região de Chadrinsk, província de Perm, por A. N. Zyrianov. O manuscrito se encontra no arquivo da Sociedade Geográfica e corresponde ao texto publicado, com exceção das palavras de baixo calão presentes no manuscrito.

2. $111 / 62 \mathrm{~d} \quad 327 \mathrm{C}$

Texto anotado na província de Sarátov, por K. A. Gusskov.

3. $141 / 81 \mathrm{a} \quad$ AT 301

Lugar de anotação desconhecido.

4. 161/96 AT 301 (parcialmente)

Lugar de anotação desconhecido.

5. $172 / 104 \mathrm{~b} \quad$ AT 551

Lugar de anotação desconhecido. 
6. $173 / 104 c \quad$ AT 551

Lugar de anotação desconhecido.

7. 201/117 AT $314 \mathrm{~A}^{+}$

Anotado em Bobrov, pertencente à província de Vorónej.

8. 204/118c $\quad$ AT $315+300$

Lugar de anotação desconhecido.

9. 235/129b AT 432 e em parte $425 \mathrm{C}$

Anotado na província de Vólogda.

10. 269/150c AT $402+401_{1}$.

Anotado na província de Sarátov.

11. 104/59 AT 480B*

Lugar de anotação desconhecido. Este conto parece ter passado por uma elaboração literária. 
Contos traduzidos 


\section{A Baba-Iagá e o menino audacioso (106)}

Viviam juntos um gato, um pardal e um menino audacioso. O gato e o pardal foram cortar lenha e falaram para o menino audacioso: "Cuide da casa e preste atenção, se a Iagá-Baba ${ }^{1}$ chegar e começar a contar as colheres, não fale nada, fique quieto!” “Está bem.” - respondeu o menino audacioso. O gato e o pardal saíram, e o menino audacioso se sentou em cima da piétch ${ }^{2}$ atrás da chaminé. De repente, surgiu a IagáBaba, pegou as colheres e começou a conferir: "Esta colher é do gato, esta colher é do pardal, e esta terceira, do menino audacioso.” O menino audacioso não agüentou e gritou: “Não toque na minha colher, Iagá-Baba.” A Iagá-Baba agarrou o menino audacioso, sentou dentro do seu pilão e partiu; com o socador açoitava e com a vassoura apagava o seu rastro. O menino audacioso abriu o berreiro: “Corra, gato; voe, pardal!” Eles o escutaram e vieram correndo. O gato começou a arranhar e o pardal a bicar a Iagá-Baba, e assim tiraram o menino audacioso de lá.

No outro dia, eles começaram novamente a se preparar para cortar lenha na floresta e ordenaram ao menino audacioso: “Cuidado, se a Iagá-Baba vier, não fale nada, hoje nós estamos indo para mais longe.” E assim que o menino audacioso se sentou em cima da piétch, atrás da chaminé, a Iagá-Baba novamente surgiu e começou a conferir as colheres: "Esta colher é do gato, esta colher é do pardal, e esta do menino audacioso.” O menino audacioso não agüentou e abriu o berreiro: “Não toque na minha colher, Iagá-Baba.” A Iagá-Baba agarrou o menino audacioso e o arrastou, mas o menino audacioso berrou: “Corra, gato; voe, pardal!” Eles o escutaram e vieram correndo; o gato começou a arranhar e o pardal a bicar a Iagá-Baba! Tiraram o menino audacioso de lá e foram para casa.

No terceiro dia, eles se prepararam para cortar lenha na floresta e falaram para o menino audacioso: “Cuidado, se a Iagá-Baba vier, fique quieto, hoje nós estamos indo para mais longe ainda.” O gato e pardal saíram, e o menino audacioso se sentou em cima da piétch, atrás da chaminé. De repente, mais uma vez a Iagá-Baba pegou as colheres e as conferiu: "Esta colher é do gato, esta colher é do pardal, e esta terceira, do menino audacioso.” E o menino audacioso quieto. A Iagá-Baba conferiu outra vez: “Esta colher é do gato, esta é do pardal, e esta do menino audacioso.” E o menino audacioso quieto. A Iagá-Baba pela terceira vez conferiu: “Esta colher é do gato, esta

\footnotetext{
${ }^{1}$ A Baba-Iagá também pode ser chamada de Iagá-Baba ou Iaguíchna.

${ }^{2}$ Ver Glossário, p. 162.
} 
colher é do pardal, e esta terceira, do menino audacioso.” O menino audacioso não agüentou e começou a gritar: "Não toque na minha colher, sua puta.” A Iagá-Baba agarrou o menino audacioso e o arrastou. O menino audacioso gritou: "Corra, gato; voe, pardal!” Mas o seus irmãos não o ouviram.

A Iagá-Baba arrastou o menino audacioso para a sua casa e o prendeu na despensa ao lado da piétchka ${ }^{3}$. E enquanto ela acendia a piétch, disse para a sua filha mais velha: "Ei, moça ${ }^{4}$, eu vou para a Rus ${ }^{5}$, e você me asse esse menino audacioso para o almoço. “Está bem!” - disse ela. A piétchka foi aquecida, e a moça mandou que o menino audacioso saísse. Ele saiu. "Deite-se na assadeira” - falou a moça. O menino audacioso se deitou, mas colocou um pé no teto e o outro no chão. A moça falou: "Não, não é assim!” E o menino audacioso respondeu: “Mas como é então? Me ensine.” A moça deitou-se na assadeira. O menino audacioso não se intimidou, pegou uma forquilha e empurrou a assadeira para dentro da piétch com a filha da Iaguíchna, depois ele voltou para a despensa, sentou-se e ficou esperando a Iagá-Baba. De repente, a Iagá-Baba chegou correndo e disse: "Vou me esfregar, vou rolar nos ossinhos do menino audacioso!" E o menino audacioso lhe respondeu: "Se esfregue e role nos ossinhos de sua filha!”

A Iagá-Baba caiu em si, viu que era a sua filha que estava assada e começou a berrar: “Ah, seu trapaceiro, espere só! Você não vai escapar!” Ordenou, então, à sua filha do meio para assar o menino audacioso e saiu. A filha do meio aqueceu a piétchka, mandou o menino audacioso sair. O menino audacioso saiu, deitou na assadeira, colocou um pé no teto e o outro no chão. A moça falou: “Não, não é assim!” "Me ensine como é então.” A moça deitou na assadeira. O menino audacioso rapidamente a empurrou para dentro da piétch, voltou para a despensa e ficou lá sentado. De repente, chegou a Iagá-Baba: “Vou me esfregar, vou rolar nos ossinhos do menino audacioso!” E ele lhe respondeu: "Se esfregue e role nos ossinhos de sua filha!” A Iaguíchna ficou furiosa: “Eh, espere só - falou - você não vai escapar!” Ordenou à filha mais nova que o assasse. Mas isso não aconteceu, e o menino audacioso a assou também!

\footnotetext{
${ }^{3}$ Diminutivo de piétch.

${ }^{4}$ No original diévka, forma pejorativa de diévuchka (moça). Assim, além de moça propriamente dita, o vocábulo significa também rapariga, meretriz.

${ }^{5}$ Rus, além do significado geográfico, como designação para a primeira formação dos estados eslavos no século IX, tem também o sentido de mundo, o que pode suscitar a idéia de que a Baba-Iagá saía do mundo dos mortos ou simplesmente que está indo para um lugar povoado em oposição ao seu que seria ermo.
} 
A Iagá-Baba ficou ainda mais furiosa. "Espera só que você vai ver - falou - você não vai escapar de mim!” Aqueceu a piétch e gritou: “Saia, menino audacioso! Deite-se na assadeira.” O menino audacioso deitou, colocou um pé no teto e o outro no chão, não passando pela boca do forno. A Iagá-Baba falou: “Não, não é assim!” O menino audacioso fingiu que não sabia. - “Eu não sei como é - falou - me ensine!” a Iagá-Baba imediatamente se encolheu e deitou na assadeira. O menino audacioso não se intimidou e rapidamente a empurrou para dentro da piétch; depois foi para casa correndo e contou aos seus irmãos: "E foi isso que eu fiz com a Iagá-Baba!”

\section{joa}




\section{Ivachko e a bruxa IV ${ }^{1}(111)$}

Em certa aldeia, viviam um velho e uma velha que não tinham filhos. Uma vez, durante o inverno, o velho foi para a floresta apanhar lenha. O velho cortou o quanto precisava de madeira e cortou ainda um toquinho de tília. Voltou para casa e deixou a lenha no quintal, mas levou o toquinho de tília para dentro da isbá e o colocou debaixo da piétchka. No terceiro dia, algo começou a fazer barulho debaixo da piétchka e depois gritou: “Papai! Mamãe! Tirem-me daqui.” O velho e a velha se espantaram e mais uma vez escutaram a mesma voz: "Papai! Mamãe! Tirem-me daqui.” O velho olhou debaixo da piétchka e viu um menininho. Tirou-o de lá e o mostrou para a velha, eles o chamaram de Lutónka² e começaram a lhe dar de comer e de beber.

Chegou o verão, e o menino começou a pescar e com isso dava de comer ao velho e à velha. A velha costumava ir até o lugar onde ele pescava e chamá-lo: "Lutón, Lutón, Lutóniuchka! Venha, reme até a margem, eu lhe trouxe uma tortinha.” Assim que Lutón ouvia a voz da sua mãe, aproximava-se da margem. Recebia da sua mãe um pedaço de torta e lhe dava a pesca. Uma vez, depois de espiar esta situação, a Iagá-Baba foi até o lugar da pescaria e começou a chamar Lutón com as mesmas palavras que a mãe dele usava. Lutóniuchka escutou a voz grossa da Iagá-Baba e respondeu: "Não, esta não é a voz da minha mãe, é muito grossa! Vá amolar esta língua!” E então, a Iagá-Baba tomou o seu rumo. Depois disso, chegou a sua velha mãe e começou a chamá-lo: "Lutón, Lutón, Lutóniuchka! Venha, reme até a margem, eu lhe trouxe uma tortinha.” Lutónka ouviu a voz da sua mãe, aproximou-se da margem, recebeu dela um pedaço de torta e lhe deu a pesca.

A velha se foi, e a Iagá-Baba amolou sua língua na amoladeira. Logo depois, ela chegou correndo até a margem e começou a chamar Lutóniuchka. Lutónka não reconheceu a voz dela, achou que era sua mãe que o chamava e se aproximou da margem. A Iagá-Baba o agarrou e o arrastou para a sua isbá. A Iagá-Baba tinha três

\footnotetext{
${ }^{1}$ Originalmente este conto não possui um título específico. Faz parte de um grupo de quatro contos, dos quais o nome do primeiro vale para as demais variantes. Neste caso, o conto apresentado é a quarta variante. Como variantes, os contos possuem personagens com a mesma função, mas não exatamente com os mesmos nomes. Dessa forma, muitos tradutores optam por substituir o nome dos personagens do título pelo seu equivalente na variante. Assim, este conto poderia ser intitulado como Lutónka e a Iagá-Baba.

${ }^{2}$ Lutónka é uma forma diminutiva de lutókha ou lutóchka (também diminutivo de lutókha), isto é, lípka, tiliazinha. A tília é uma árvore utilizada na fabricação de diversos produtos como cordas, sapatos (os tradicionais lápt), utensílios domésticos etc.
} 
filhas. Ela ordenou à filha mais velha que deixasse a isbá, muito, muito quente ${ }^{3}$ e assasse Lutónka, enquanto ela própria saiu para passear no campo. A filha mais velha esquentou a isbá, trouxe Lutónka e mandou ele se sentar na pá. Lutónka que não era tolo, começou a disfarçar, a fingir que não sabia, que não tinha idéia de como se sentava na pá: “Mostre - pediu - como se deve sentar!” A filha da Iagá-Baba sentou na pá, Lutónka então pegou a pá pelo cabo e a enfiou dentro da piétch. E ele próprio se escondeu no sótão. Chegou a Iagá-Baba e perguntou por Lutónka, as filhas tiraram a irmã delas da piétch e a serviram para a mãe que a comeu. Depois, ela saiu no quintal e falou: “Vou me esfregar, vou rolar nos ossinhos de Lutóniuchka!” E Lutónka do sótão falou para si mesmo: "Se esfregue e role nos ossinhos de sua filha!"

A Iagá-Baba notou Lutónka e começou a gritar: "Vou pegá-lo de qualquer jeito, Lutónka!” Ela pegou Lutónka e o entregou para suas filhas, ordenando que elas o assassem, e ela própria saiu novamente. As filhas aqueceram a isbá, a filha do meio queria colocar Lutónka na pá, mas ele a enganou e a enfiou na piétch. E o mesmo ele fez com a irmã mais nova. Iagá-Baba chegou em casa e começou a chamar suas filhas, não havia ninguém. Ela própria retirou o assado e o comeu, depois saiu para o quintal e disse: “Vou me esfregar, vou rolar nos ossinhos de Lutóniuchka!” E Lutónka do sótão respondeu: "Se esfregue e role, sua imbecil, nos ossinhos das suas filhas!” A Iagá-Baba o notou, ficou furiosa e quis pegá-lo. Lutónka começou a gritar com uma voz chorosa: “Ah, gansos, ah, cisnes! Voem até aqui, arranquem uma peninha de cada um de vocês.” Os gansos e cisnes vieram, cada um arrancou de si uma peninha, fizeram duas asinhas e as deram para Lutóniuchka. Lutónka as pegou e fugiu voando da Iagá-Baba, voltando para a casa do seu pai e da sua mãe e então eles passaram a viver tranqüilos e felizes e a pescar.

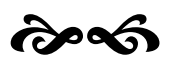

\footnotetext{
${ }^{3}$ Assim no original, porém, subentende-se que a filha esquentou a piétch que por ter também a função de aquecedor consequentemente aqueceu toda a isbá.
} 


\section{Os bogatyrí ${ }^{1}$ Medviédko $^{2}$, Ussýnia, Gorýnia e Dubýnia ${ }^{3}$ (141)}

Em certo reino, em certo estado, viviam um velho e uma velha que não tinham filhos. Uma vez, o velho falou: "Velha, vá comprar uns nabinhos para o almoço.” A velha foi e comprou dois nabinhos; um eles roeram com dificuldade, e o outro eles colocaram na piétch para amolecer. Pouco tempo depois, ouviram algo gritar na piétch: “Vovó, abra, está muito quente!” A velha abriu a porta, e na piétch estava deitada uma menina. “O que tem aí?” perguntou o velho. “Ah, velho! O Senhor nos deu uma menina.” O velho e a velha se alegraram muito e a chamaram de Riépka. ${ }^{4}$

Então, Riépka cresceu, cresceu e se tornou uma moça. Um dia, as moças da aldeia chegaram e pediram: "Vovó, deixe a Riépka ir conosco para a floresta colher frutinhas." "Não deixo, suas filhas da p...a的! Vocês vão abandoná-la na floresta.” "Não, vovó, não vamos abandoná-la de jeito nenhum.” A velha deixou que Riépka fosse. As moças aprontaram-se, foram colher frutinhas e acabaram entrando numa floresta tão densa que não se via nada. Perceberam uma isbazinha na floresta, entraram na isbazinha e lá encontram um urso sentado sobre um tronco de árvore. “Olá, belas moças!”, disse o urso. "Estou esperando vocês há muito tempo.” Sentou-as à mesa, serviu um mingau para elas e disse: "Comam, minhas belas, minhas lindas! Aquela que não comer vai se casar comigo.” Todas as moças comeram o mingau, somente Riépka não comeu. O urso deixou as moças voltarem para casa, mas Riépka ele manteve junto de si. Ele trouxe um trenó, o pendurou no teto feito uma balança, deitou-se sobre ele e obrigou a moça a balançá-lo. Riépka começou a balançá-lo e a repetir: “Nana, velho diabo!” “Não, não é assim - falou o urso - diga: Nana, meu querido!” Não havia o que fazer, e a moça começou a balançá-lo e a falar: "Nana, nana, meu querido!”

E assim viveram o urso e a moça quase um ano. Riépka embarrigou e começou a pensar como poderia encontrar uma ocasião para voltar para casa. Uma vez, o urso foi caçar, a deixou na isbazinha e prendeu a porta com cepos de carvalho. Riépka tentou arrancá-los, forçou, forçou e com dificuldade saiu e correu para casa. O velho e a velha alegram-se com a sua volta. Passou um mês, dois, três e no quarto mês, Riépka deu à luz um filho, metade humano metade urso, batizaram-lhe e deram-lhe o nome de

\footnotetext{
${ }^{1}$ Ver Glossário, p. 160.

${ }^{2}$ Diminutivo de medviéd', isto é, urso.

${ }^{3}$ Ver Glossário, p. 160.

${ }^{4}$ Diminutivo de riépa, nabo.

${ }^{5}$ No original k...ny, tudo indica que se refira ao adjetivo possessivo kúrviny, isto é, da puta.
} 
Ivachko ${ }^{6}$-Medviédko. Ivachko começou a crescer não ano a ano, mas hora a hora; a cada hora, ele esticava um verchók ${ }^{7}$ como se alguém o puxasse para a montanha. Ele completou quinze anos e começou a sair com a rapaziada para se divertir e fazer brincadeiras maldosas: quem ele agarrasse pelo braço, perdia o braço, quem ele agarrasse pela cabeça, perdia a cabeça.

Os mujiques foram reclamar com o velho: "Faça como quiser, compadre, mas não dá mais para o seu filho continuar aqui! Nós não queremos perder nossos filhos por causa da força desenfreada dele.” O velho entristeceu-se e desanimou-se. "O que foi, vovô, por que está tão triste?” - perguntou Ivachko-Medviédko. “Alguém o aborreceu?” O velho deu um suspiro profundo e disse: “Ah! Meu netinho. Você era o meu único sustento, mas ordenaram que você deixe a aldeia.” "Pois bem, vovô! Isso ainda não é desgraça. Desgraça é que não tenho com o que me defender. Vá, faça para mim um porrete de ferro de 25 puds $^{8}$." O velho foi e fez para o neto um porrete de 25 puds. Ivachko se despediu do avô e da avó, pegou o seu porrete e seguiu para onde os olhos alcançavam.

Indo pela estrada, chegou até um rio de três verstas ${ }^{9}$ de largura; na margem havia um homem que barrava o rio com a boca, pescava com o bigode, cozinhava na língua e comia. “Olá, bogatýr Ussýnia!” - “Olá, Ivachko-Medviédko! Para onde você está indo?” - “Eu próprio não sei, estou indo para onde os olhos alcançam.” - "Leve-me com você.” - "Vamos, irmão! Me agrada ter companhia.” Os dois seguiram e encontraram um bogatýr, tal bogatýr arrancava montanhas inteiras e as colocava em barrancos para nivelar o caminho. Ivachko ficou pasmado: “Nossa, isso é o que eu chamo de milagre! Você é muito forte, Gorýniuchka! ${ }^{10 ”}$ - “Ah, irmãos, forte, eu? No mundo existe Ivachko-Medviédko, ele sim tem uma força realmente enorme!” - "Mas esse sou eu!” “Para onde você está indo?” - "Para onde os olhos alcançam.” - "Leve-me com você.” - "Então, vamos, me agrada ter companhia."

Os três seguiram e encontraram uma maravilha: um bogatýr que nivelava os carvalhos, empurrava para a terra aqueles que eram altos e puxava da terra os que eram baixos. Ivachko ficou pasmado: “Que força, que poder enorme!” - “Ah, irmãos, forte eu? No mundo existe Ivachko-Medviédko, ele sim é realmente forte!” - "Mas esse sou

\footnotetext{
${ }^{6}$ Diminutivo de Ivan.

${ }^{7}$ Antiga medida russa, correspondente a $4,4 \mathrm{~cm}$.

${ }^{8}$ Antiga medida russa de peso, equivalente a $16,38 \mathrm{~kg}$.

${ }^{9}$ Antiga medida russa, equivalente a $1,067 \mathrm{~km}$.

${ }^{10}$ Diminutivo de Gorýnia.
} 
eu!” - “Para onde Deus o está levando?” - “Eu próprio não sei, Dubýniuchka ${ }^{11}$ ! Estou indo até onde os olhos alcançam.” - "Leve-me com você.” - "Então, vamos, me agrada ter companhia.” E os quatro foram juntos.

Eles seguiram pela estrada, por um tempo nem longo nem curto e acabaram entrando numa sombria e densa floresta. Nessa floresta havia uma pequena isbazinha sobre uma perna de galinha, que girava e girava ${ }^{12}$. Ivachko falou: "Isbazinha, isbazinha, fique de costas para a floresta e de frente para nós.” A isbazinha virou de frente para eles, a porta se abriu, as janelas se abriram. Os bogatyrí entraram na isbazinha e não havia ninguém, mas no quintal havia gansos, patos e perus em fartura! "Então, irmãos falou Ivachko-Medviédko - não dá para todo mundo ficar em casa, vamos fazer um sorteio para saber quem ficará e quem irá caçar.” Fizeram o sorteio e o escolhido para ficar foi o bogatýr Ussýnia.

Os seus assim chamados irmãos saíram para caçar, e ele preparou e cozinhou tudo aquilo que sua alma desejava, depois lavou a cabeça, sentou-se debaixo da janelinha e começou a pentear seus cachos com um pente. De repente, tudo começou a girar e a escurecer, seus olhos se embaçaram, a terra começou a se levantar como uma barriga e de debaixo da terra saiu uma pedra e de debaixo da pedra a Baba-Iagá, perna de osso, b... seca ${ }^{13}$, no seu pilão de ferro, açoitando com seu socador de ferro; atrás dela veio uma cachorrinha latindo. "Vou beber e comer na casa do bogatýr Ussýnia” - "Bemvinda, Baba-Iagá, perna de osso!” Ele a sentou à mesa e lhe serviu uma porçãozinha, ela comeu. Ele serviu outra, e ela deu para a sua cachorrinha: "Então é assim que você me serve!” Ela pegou o socador e começou a bater em Ussýniuchka ${ }^{14}$, bateu, bateu e o encurralou debaixo de um banco; das costas dele, ela cortou uma tira, comeu tudo o que tinha e foi embora. Ussýnia voltou a si, amarrou um lencinho na cabeça, sentou e ficou gemendo. Chegou Ivachko-Medviédko com seus irmãos: “Vamos, Ussýniuchka, nos sirva o almoço que você preparou” - “Ah, irmãos, não cozinhei nem assei nada: passei mal com a fumaça que tomou conta da isbá quando fui acender a piétch.

No outro dia, ficou em casa o bogatýr Gorýnia; cozinhou e preparou, depois lavou a cabeça, sentou-se debaixo da janelinha e começou a pentear seus cachos com um pente. De repente, tudo começou a girar e a escurecer, seus olhos se embaçaram, a terra

\footnotetext{
${ }^{11}$ Diminutivo de Dubýnia.

${ }^{12}$ Segundo Propp, essa expressão é resultado de uma compreensão errônea. Na verdade, a isbazinha não giraria o tempo todo, mas somente diante das palavras do herói. (Propp, Raízes históricas..., p. 57)

${ }^{13}$ No original $j . .$. jílenaia. Acredita-se que o j... se refere à palavra jópa, isto é, bunda, e que o adjetivo jílenyi é o mesmo que jíl'nyi: de tendão, por isso, optou-se por seca.

${ }^{14}$ Diminutivo de Ussýnia.
} 
começou a se levantar como uma barriga, de debaixo da terra saiu uma pedra e de debaixo da pedra, a Baba-Iagá, perna de osso, no seu pilão de ferro, açoitando com seu socador de ferro; atrás dela veio uma cachorrinha latindo. "Vou beber e me divertir na casa de Gorýniuchka” - “Bem-vinda, Baba-Iagá, perna de osso!” Ela se sentou e Gorýnia lhe serviu uma porçãozinha, a Baba-Iagá comeu. Ele serviu outra, e ela deu para a sua cachorrinha: “Então é assim que você me serve!” Ela pegou o socador de ferro e bateu nele, bateu e o encurralou debaixo de um banco; das costas dele, ela cortou uma tira, comeu tudo até a última migalha e foi embora. Gorýnia recuperou os sentidos, amarrou a cabeça e andava e gemia. Ivachko-Medviédko voltou com seus irmãos: “Vamos, Gorýniuchka, o que você preparou de almoço para nós?” - “Ah, irmãos, não cozinhei nada: a piétch estava cheia de fuligem, as lenhas úmidas e tudo ficou cheio de fumaça quando fui acender a piétch.

No terceiro dia, ficou em casa o bogatýr Dubýnia; preparou e cozinhou, depois lavou a cabeça, sentou-se debaixo da janelinha e começou a pentear seus cachos. De repente, tudo começou a girar e a escurecer, seus olhos se embaçaram, a terra começou a se levantar como uma barriga e de debaixo da terra saiu uma pedra e de debaixo da pedra, a Baba-Iagá, perna de osso, no seu pilão de ferro, açoitando com seu socador de ferro; atrás dela veio uma cachorrinha latindo. "Vou beber e me divertir na casa de Dubýniuchka!” - “Bem-vinda, Baba-Iagá, perna de osso!” A Baba-Iagá sentou e ele lhe serviu uma porçãozinha, ela comeu. Ele serviu outra, e ela jogou para a sua cachorrinha: “Então é assim que você me serve!” Ela apanhou o socador e bateu nele, bateu e o encurralou debaixo de um banco; das costas dele, ela cortou uma tira, comeu tudo e foi embora. Dubýnia voltou a si, amarrou a cabeça e andava e gemia. Ivachko voltou com seus irmãos: "Vamos, Dubýniuchka, nos sirva o almoço” - "Não cozinhei nada, irmãos: passei mal com a fumaça que tomou conta da isbá quando fui acender a piétch.

No quarto dia, chegou a vez de Ivachko. Ele ficou em casa, cozinhou e preparou, depois lavou a cabeça, sentou-se debaixo da janelinha e começou a pentear seus cachos com um pente. De repente, tudo começou a girar e a escurecer, seus olhos se embaçaram, a terra começou a se levantar como uma barriga e de debaixo da terra saiu uma pedra e de debaixo da pedra, a Baba-Iagá, perna de osso, no seu pilão de ferro, açoitando com seu socador de ferro; atrás dela veio uma cachorrinha latindo. "Vou beber e me divertir na casa de Ivachko-Medviédko.” - “Bem-vinda, Baba-Iagá, perna de osso!” Ele a sentou e lhe serviu uma porçãozinha, ela comeu. Ele serviu outra, e ela jogou para a sua cadelinha: “Então é assim que você me serve!” Ela pegou o socador e 
começou a acuá-lo, Ivachko irritou-se, arrancou o socador da Baba-Iagá e começou a bater nela com toda a força, bateu, bateu, a espancou até deixá-la meio morta, cortou das costas dela três tiras, pegou a Baba-Iagá, a prendeu na despensa e trancou.

Chegaram os companheiros: “Ivachko, vamos almoçar!” - “Queiram se sentar, amigos.” Eles se sentaram, e Ivachko começou a servi-los, havia preparado de tudo. Enquanto comiam, os bogatyrí estranhavam e conversavam: "Parece que a Baba-Iagá não esteve por aqui.” Depois do almoço, Ivachko-Medviédko aqueceu a bánia ${ }^{15}$ e eles foram tomar banho. Ussýnia, Dubýnia e Gorýnia lavaram-se, fazendo de tudo para ficar de frente para Ivachko. Ivachko falou para eles: "Por que vocês, irmãos, estão escondendo as suas costas de mim?” Os bogatyrí não tinham mais o que fazer e confessaram como a Baba-Iagá os tinha visitado e cortado uma tira das costas de cada um. - “Ah, então é com isso que vocês passaram mal!” - disse Ivachko, que correu até a despensa, tirou as tiras da Baba-Iagá e as colocou novamente nas costas deles, no mesmo instante tudo se cicatrizou. Depois disso, Ivachko pegou a Baba-Iagá e com uma corda prendeu-a pela perna e a pendurou no portão: "Então, irmãos, preparem suas espingardas e vamos praticar tiro ao alvo: quem conseguir romper a corda com a bala, será o vencedor.” O primeiro a atirar foi Ussýnia e errou. O segundo que atirou foi Gorýnia e a bala passou perto, o terceiro, Dubýnia, errou por muito, muito pouco, e então Ivachko atirou e rompeu a corda. A Baba-Iagá caiu no chão, se levantou em um pulo e foi correndo até a pedra, a levantou e fugiu para debaixo da terra.

Os bogatyrí lançaram-se à sua perseguição. Um tentou, o outro tentou, mas não conseguiram levantar a pedra, então Ivachko veio correndo e com um chute moveu a pedra, surgindo uma toca. “Quem irá descer, irmãos?” Ninguém quis. "Então - falou Ivachko-Medviédko - pelo visto eu terei de descer!” Pegou um tronco, fincou-o na beira do abismo, no tronco pendurou um sino e nele amarrou a ponta de uma corda, a outra ponta ele mesmo pegou. "Agora, desçam-me e quando eu bater o sino, puxem-me de volta.” Os bogatyrí começaram a soltá-lo na toca. Ivachko viu que a corda tinha acabado, mas que ainda faltava para chegar até o fundo, tirou do bolso três grandes tiras que ele havia cortado da Baba-Iagá, amarrou-as à corda e desceu para o outro mundo.

Viu uma trilha e a seguiu. Andou, andou e encontrou um palácio. No palácio havia três donzelas sentadas, três beldades, e elas lhe disseram: “Ah, jovem valente, por que veio até aqui? Pois, a Baba-Iagá é nossa mãe, e ela irá comê-lo!” - “E onde ela

\footnotetext{
${ }^{15}$ Ver Glossário, p. 158.
} 
está?” - “Agora, ela está dormindo, e junto à sua cabeça está a espada invencível ${ }^{16}$, não toque na espada, se você tocá-la, a Baba-Iagá em um minuto acordará e se lançará sobre você. Assim, é melhor você levar duas maçãzinhas de ouro sobre um pires de prata e acordar a Baba-Iagá delicadamente, oferecer as maçãzinhas para ela e com carinho pedir para que ela as prove. Ela levantará a cabeça, escancará a goela e, assim que ela começar a comer a maçãzinha, você puxa a espada invencível e corta a cabeça dela em um único golpe, e não em dois, pois se você golpeá-la outra vez, ela imediatamente ressuscitará e lhe dará uma morte cruel.” Ivachko assim fez, cortou a cabeça da BabaIagá, apanhou as belas donzelas e as levou até a toca, amarrou a irmã mais velha na corda, bateu o sino e gritou: “Ussýnia, eis uma esposa para você!” Os bogatyrí a puxaram e jogaram a corda para baixo. Ivachko amarrou a outra irmã: "Gorýnia, eis uma esposa para você!” E então eles a puxaram. Ivachko amarrou a irmã caçula e gritou: “E esta é a minha esposa!” Dubýnia se irritou, e logo que eles começaram a puxar Ivachko-Medviédko, ele pegou uma clava e cortou a corda.

Ivachko caiu e se machucou muito; o jovem valente voltou a si e não sabia o que fazer. Ficou sentando durante um dia, dois, três sem comer nem beber, emagreceu de fome até que pensou: "Vou ver se não há algo para matar a fome nas despensas da Baba-Iagá.” Foi ate à despensa, comeu, bebeu e encontrou uma passagem subterrânea, andou, andou e saiu no seu mundo. Caminhando por uma vasta planície, viu uma bela donzela pastoreando o gado, aproximou-se dela e reconheceu a sua noiva. - "O que está fazendo, minha querida?” - “Pastoreando o gado, minhas irmãs vão se casar com os bogatyrí, mas eu não quero me casar com Dubýniuchka, por isso ele me mandou cuidar das vacas.” À noite, a bela donzela conduziu o rebanho para casa, e Ivachko-Medviédko a seguiu. Chegou a uma isbá; Ussýnia, Gorýnia e Dubýnia estavam à mesa se divertindo. Ivachko falou para eles: "Vocês me serviriam uma bebidinha, gente boa?” Ofereceram-lhe um cálice de vodca ${ }^{17}$, ele bebeu e pediu outro, deram-lhe, ele bebeu e pediu o terceiro; e assim que bebeu o terceiro, inflamou-se o seu coração de bogatýr: ele pegou uma clava de combate, matou todos os três bogatyrí e jogou os seus corpos na vasta planície para que ficassem à mercê dos animais ferozes. Depois disso, pegou sua

\footnotetext{
${ }^{16}$ Imagem típica de guerreiros que dormem ou são enterrados com suas espadas.

${ }^{17}$ No original ziéleno vinó, um dos antigos nomes dados à vodca. Ziéleno vinó, entretanto, tornou-se uma denominação típica das obras folclóricas para vodca. Inicialmente, devemos lembrar que no passado o termo vinó servia para designar tanto a vodca quanto o vinho de uva. Já o termo ziéleno vinó, recebe duas possíveis explicações. A primeira se refere ao fato de ziéleno vir de ziél'eno, de ziél'e (elixir, aguardente) e não de zelionoe (verde). A segunda defende a idéia de que possivelmente essa vodca tinha o tom esverdeado sim por ser de má qualidade. Outras formas como a vodca era chamada: khliébnoe vinó (vinho de pão), variónoe vinó (vinho cozido), goriátchieie vinó (vinho quente).
} 
noiva prometida, retornou para a casa do velho e da velha e celebraram um alegre casamento. Muito se comeu e se bebeu nesse casamento. Eu estava lá, bebi hidroméis e $\operatorname{vinhos}^{18}$, que do bigode escorriam, mas na boca não caíam. Dê uma concha de cerveja para mim que o conto chegou ao fim.

Doa

${ }^{18}$ No original vinó, assim eram chamados os vinhos propriamente ditos, feitos de uva, e também a vodca. 


\section{Ivan-tsarévitche e Biélyi Poliánin ${ }^{1}$ (161)}

Em certo reino, em certo estado, vivia um tsar. Esse tsar tinha três filhas e um filho, Ivan-tsarévitche. O tsar envelheceu e morreu, e Ivan-tsarévitche assumiu a coroa. Assim que os reis vizinhos ficaram sabendo disso, reuniram suas inumeráveis tropas e partiram em guerra contra ele. Ivan-tsarévitche não sabia o que fazer, foi até as suas irmãs e perguntou: "Minhas irmãs amadas! O que devo fazer? Todos os reis estão em guerra contra mim” - “Ah, mas que bravo guerreiro! Você está com medo de quê? E o Biélyi Poliánin que luta contra a Baba-Iagá, perna de ouro, há trinta anos, sem descer do cavalo e sem conhecer o descanso? Enquanto você ainda nem viu nada e já está assustado!” Ivan-tsarévitche no mesmo momento selou seu bom cavalo, vestiu a sua armadura de guerreiro, pegou a sua espada invencível, a sua longa lança e o seu chicote de seda, rezou a Deus e foi de encontro ao inimigo. Muitos foram mortos sob sua espada, mas muitos mais foram pisoteados pelo seu cavalo, exterminou todos os exércitos inimigos, voltou para a cidade e foi dormir e dormiu por três dias e por três noites um sono profundo. No quarto dia, ele acordou, saiu até a sacada, olhou para a vasta planície e viu que os reis tinham reunido ainda mais tropas e novamente elas se aproximavam das muralhas.

O tsarévitche se entristeceu e foi até as suas irmãs: “Ah, irmãzinhas! O que devo fazer? Um exército eu destruí, mas outro está nos arredores da cidade e é ainda mais ameaçador do que o anterior. - "Mas que espécie de guerreiro você é! Lutou um dia, e, três, dormiu sem acordar. E o Biélyi Poliánin que luta contra a Baba-Iagá, perna de ouro, há trinta anos, sem descer do cavalo e sem conhecer o descanso?” Ivan-tsarévitche correu até a estrebaria de pedras brancas, selou seu bom e poderoso cavalo, vestiu a sua armadura de guerreiro, cingiu a sua espada invencível, em uma mão pegou a sua longa lança e na outra o seu chicote de seda, rezou a Deus e foi de encontro ao inimigo. Como um falcão brilhante ${ }^{2}$ ataca um bando de gansos, cisnes e patos cinza, Ivan-tsarévitche atacou as tropas inimigas. Muitos foram mortos por ele, mas muitos mais foram

\footnotetext{
${ }^{1}$ A tradução literal de Biélyi Poliánin seria clareira branca.

${ }^{2}$ No original iásnyi, brilhante, claro, luminoso. Porém, neste caso, o significado de brilhante refere-se ao seu sentido figurado de magnificente, notável, excepcional, admirável e não necessariamente a sua forma física como no caso do pássaro de fogo (jar-ptítsa). Nos cantos e canções russas, a expressão iásnyi sókol, ou seja, falcão brilhante, geralmente refere-se a um jovem que se destaca pela sua valentia, coragem e beleza. Há ainda o personagem Finíst, o falcão brilhante, um jovem que se transforma em falcão durante o dia e em um belo homem durante a noite.
} 
pisoteados pelo seu cavalo, venceu o grande exército inimigo, voltou para casa e foi dormir e dormiu por seis dias e por seis noites um sono profundo. No sétimo dia, ele acordou, saiu até a sacada, olhou para a vasta planície e viu que os reis tinham reunido ainda mais tropas e novamente toda a cidade estava cercada.

Ivan-tsarévitche foi até as suas irmãs: "Minhas irmãs amadas! O que devo fazer? Dois exércitos eu destruí, mas um terceiro está nos arredores das muralhas e é ainda mais ameaçador. - “Ah, mas que bravo guerreiro! Lutou um dia, e, seis, dormiu sem acordar. E o Biélyi Poliánin que luta contra a Baba-Iagá, perna de ouro, há trinta anos, sem descer do cavalo e sem conhecer o descanso?” A mágoa tomou conta do tsarévitche, que correu até a estrebaria de pedras brancas, selou seu bom e poderoso cavalo, vestiu a sua armadura de guerreiro, cingiu a sua espada invencível, em uma mão pegou a sua longa lança e na outra o seu chicote de seda, rezou a Deus e foi de encontro ao inimigo. Como um falcão brilhante ataca um bando de gansos, cisnes e patos cinzas, Ivan-tsarévitche atacou as tropas inimigas. Muitos foram mortos por ele, mas muitos mais foram pisoteados pelo seu cavalo, venceu o grande exército inimigo, voltou para casa e foi dormir e dormiu por nove dias e por nove noites um sono profundo. No décimo dia, ele acordou, convocou todos os ministros e senadores e disse: "Meus prezados ministros e senadores, resolvi partir para terras estrangeiras, para conhecer Biélyi Poliánin. Peço-lhes que julguem e governem, analisando todos os casos com justiça.” Depois se despediu das suas irmãs, montou no cavalo e partiu em viagem.

Nem longo nem curto, o tempo passou, e ele entrou numa sombria floresta; viu uma isbazinha e na isbazinha vivia um velho. Ivan-tsarévitche entrou nela e disse: “Olá, vovô!” - “Olá, tsarévitche russo! Para onde Deus o está levando?” - “Estou procurando Biélyi Poliánin, você não saberia onde ele está?” - “Eu próprio não sei, mas espere, reunirei meus fiéis servos e perguntarei a eles.” O velho saiu até a soleira e tocou uma corneta de prata. De repente, de todos os lados começaram a chegar pássaros. Eram tantos e tantos que cobriam o céu como uma nuvem negra. O velho então gritou em voz alta e assobiou fortemente: "Meus fiéis servos, pássaros migratórios! Vocês já viram ou ouviram algo sobre Biélyi Poliánin?” - “Não, não vimos nem ouvimos” - “Então, Ivantsarévitche, - falou o velho - vá até o meu irmão mais velho, talvez ele lhe fale algo. Mas antes pegue um novelinho e o solte na sua frente: para onde ele rolar é para lá que você tem de conduzir o seu cavalo.” Ivan-tsarévitche sentou no seu bom cavalo, jogou o novelinho e começou a segui-lo; e a floresta ficava cada vez mais e mais sombria. 
O tsarévitche chegou a uma isbazinha e entrou, e na isbazinha estava sentado um velho de cabelos brancos como a lua. - “Olá, vovô!” - “Olá, tsarévitche russo! Para onde você se dirige?” - “Estou procurando Biélyi Poliánin, você não saberia onde ele está?” - “Espere, reunirei meus fiéis servos e perguntarei a eles.” O velho saiu até a soleira e tocou uma corneta de prata. De repente, de todos os lados começaram a chegar diversos animais. Ele gritou em voz alta e assobiou fortemente: "Meus fiéis servos, animais selvagens! Vocês já viram ou ouviram algo sobre Biélyi Poliánin?” - “Não responderam os animais - não vimos nem ouvimos. - "Mas, contem quantos vocês são, talvez, não tenham vindo todos.” Os animais contaram e perceberam que a loba zarolha ${ }^{3}$ não estava entre eles. O velho mandou procurá-la e no mesmo instante os seus enviados se puseram a correr e a trouxeram. - "Diga, loba zarolha, você conhece Biélyi Poliánin?” - “Como não o conheceria, se eu sempre estou ao seu lado, ele derrota as tropas e eu como os cadáveres.” - “Onde ele está agora?” - “Na vasta planície, em uma grande colina, dormindo numa tenda. Ele lutou contra a Baba-Iagá, perna de ouro, e depois da batalha, foi dormir por doze noites e por doze dias.” - "Leve Ivan-tsarévitche para lá.” A loba começou a correr e atrás dela galopava o tsarévitche.

Ele chegou à grande colina e entrou na tenda, Biélyi Poliánin dormia profundamente. "Eis o Biélyi Poliánin que minhas irmãs diziam lutar sem descansar e que, no entanto, dorme há doze dias e doze noites. Será que por ora eu também não poderia dormir?” Ivan-tsarévitche pensou, pensou e deitou-se do lado dele. Então, entrou voando na tenda, um pequeno passarinho que começou a girar sobre a cabeceira de Biélyi Poliánin e disse as seguintes palavras: “Levante, acorde, Biélyi Poliánin, e dê uma morte cruel ao meu irmão Ivan-tsarévitche: se não, ele próprio se levantará e o matará!” Ivan-tsarévitche deu um salto, capturou o passarinho, arrancou-lhe a perna direita, jogou-o para fora da tenda e novamente foi dormir ao lado de Biélyi Poliánin. Mal tinha adormecido, um outro passarinho entrou voando, começou a girar sobre a cabeceira e disse: “Levante, acorde, Biélyi Poliánin, e dê uma morte cruel ao meu irmão Ivan-tsarévitche: se não, ele próprio se levantará e o matará!” Ivan-tsarévitche deu um salto, capturou o passarinho, arrancou a sua asa direita, jogou-o para fora da tenda e novamente foi dormir no mesmo lugar. Em seguida, chegou um terceiro passarinho, começou a girar sobre a cabeceira e disse: “Levante, desperte, Biélyi Poliánin, e dê uma morte cruel ao meu irmão Ivan-tsarévitche: se não, ele próprio se levantará e o matará!”

\footnotetext{
${ }^{3}$ No original krivói, adjetivo que, além de zarolho, significa também curvo, torto.
} 
Ivan-tsarévitche deu um salto, agarrou o passarinho, arrancou-lhe o bico, jogou o passarinho para fora e dormiu profundamente.

Chegou a hora e Biélyi Poliánin acordou e viu, deitado ao seu lado, um bogatýr desconhecido, apanhou sua espada afiada e já queria lhe dar uma morte cruel, mas se conteve a tempo. "Não - pensou - ele chegou até aqui enquanto eu dormia e não quis banhar a sua espada em sangue. Que honra eu, jovem valente, teria se o matasse! Um homem dormindo é como um morto! É melhor eu acordá-lo.” Ele acordou Ivantsarévitche e perguntou: "Você é uma pessoa boa ou má? Diga, como você se chama e por que veio até aqui?” - “Eu me chamo Ivan-tsarévitche e vim para conhecê-lo e testar a sua força." - "Você é muito ousado, tsarévitche! Entra na tenda sem ser convidado e dorme sem ser anunciado, eu poderia matá-lo por isso!” - “Eh, Biélyi Poliánin! Nem pulou o fosso e já está se gabando. Espere, você ainda pode tropeçar! Você tem duas mãos, mas a minha mãe não me fez com uma.”

Então, eles montaram em seus poderosos cavalos, lançaram-se um contra o outro e chocaram-se com tanta força que as suas lanças se fizeram em pedacinhos, e os bons cavalos caíram de joelhos. Ivan-tsaréviche derrubou Biélyi Poliánin da sela e ergueu sobre ele a sua espada afiada. Biélyi Poliánin lhe implorou: “Não me mate, deixe-me viver! Passarei a ser seu irmão caçula e a honrá-lo como a um pai.” Ivan-tsarévitche o pegou pela mão, o levantou do chão, o beijou na boca e o chamou de irmão caçula: "Eu ouvi dizer, irmão, que há trinta anos você luta contra a Baba-Iagá, perna de ouro, qual é o motivo dessa guerra?” - "Ela tem uma beldade de filha, quero consegui-la e me casar com ela.” - “Então - disse o tsarévitche - já que somos amigos, devemos nos ajudar na desgraça! Vamos lutar juntos.”

Montaram em seus cavalos e partiram para a vasta planície; onde a Baba-Iagá, perna de ouro, apresentou um inumerável exército. E assim como os falcões brilhantes atacam um bando de pombos, os fortes e poderosos bogatyrí lançaram-se contra as tropas inimigas! Muitos foram mortos sob suas espadas, mas muitos mais foram pisoteados pelos seus cavalos. E eles mataram e pisotearam milhares e milhares. A Baba-Iagá escafedeu-se, e Ivan-tsarévitche foi atrás dela. Ele estava quase a alcançando, quando ela correu até um profundo abismo, levantou uma placa de ferro e sumiu debaixo da terra. Ivan-tsarévitche e Biélyi Poliánin compraram uma grande quantidade de touros, os abateram, tiraram sua pele e a cortaram em tiras, com as quais eles trançaram um cabo, tão comprido que uma ponta ficava neste mundo e a outra ia até o outro mundo. Ivan-tsarévitche falou a Biélyi Poliánin: "Desça-me rapidamente para o 
abismo, mas não tire o cabo, espere, quando eu sacudi-lo, então, você me puxa de volta.” Biélyi Poliánin o abaixou até o fim do abismo. Ivan-tsarévitche olhou ao seu redor e foi procurar a Baba-Iagá.

Andou, andou e viu atrás das grades uns alfaiates. - “O que vocês estão fazendo?” - “Isto, Ivan-tsarévitche, estamos costurando tropas para a Baba-Iagá, perna de ouro.” “E como vocês fazem isso?” - “Ah, é bem simples: a cada agulhada surge um cossaco com uma lança, ele monta no cavalo, se coloca em fila e vai combater o Biélyi Poliánin. - "Eh, irmãos! Vocês fazem isso rápido, mas sem qualidade. Formem uma fila que eu vou ensiná-los como costurar com qualidade.” Eles imediatamente enfileiraram-se, Ivan-tsarévitche girou sua espada e as cabeças voaram. Matou os alfaiates e seguiu adiante. Andou, andou e viu atrás das grades uns sapateiros. - "O que vocês estão fazendo?” - "Preparando tropas para a Baba-Iagá, perna de ouro.” - "E como vocês preparam essas tropas, pessoal?” - “Ah, assim: a cada sovelada surge um soldado com uma espingarda, ele monta no cavalo, se coloca em fila e vai combater o Biélyi Poliánin. - "Eh, irmãos! Vocês fazem isso rápido, mas sem harmonia. Formem uma fila que eu vou ensiná-los como fazer melhor.” Eles enfileiraram-se, Ivan-tsarévitche girou sua espada e as cabeças voaram. Matou os sapateiros e novamente prosseguiu.

Nem longo nem curto, o tempo passou, ele chegou a uma grande e bela cidade, nessa cidade havia majestosos tiérens ${ }^{4}$. Em um deles vivia uma donzela de beleza indescritível. Ela viu pela janela o jovem valente e se apaixonou pelos seus cachos negros, seus olhos de falcão, suas sobrancelhas de zibelina e seu jeito de bogatýr, ela insistiu para que ele entrasse e lhe perguntou para onde estava indo e por quê. Ele lhe contou que procurava a Baba-Iagá, perna de ouro. “Ah, Ivan-tsarévitche, pois eu sou filha dela, e agora ela dorme um sono profundo e vai descansar por doze dias e doze noites.” Ela o levou para fora da cidade e lhe mostrou o caminho. Ivan-tsarévitche foi até a Baba-Iagá, perna de ouro, e a encontrou dormindo, a golpeou com sua espada e cortou a cabeça dela. A cabeça saiu rolando e pronunciou: "Golpeie mais uma vez, Ivan-tsarévitche!” - “Um golpe de bogatýr é o suficiente!” - respondeu o tsarévitche e voltou para o tiérem ao encontro da bela donzela. Lá, sentou-se com ela à mesa de carvalho, coberta com toalhas bordadas. Comeu, bebeu e perguntou: "Existe alguém no mundo mais forte do que eu e mais bonita do que você?” - “Ah, Ivan-tsarévitche! Que

\footnotetext{
${ }^{4}$ Tiérem pode ser tanto uma casa em forma de torre quanto a parte superior da casa na antiga Rússia.
} 
bonita que nada! Sei que além das trinta terras, no trigésimo estado ${ }^{5}$, vive com o tsardragão uma princesa ${ }^{6}$, e esta sim tem uma beleza verdadeiramente extraordinária, eu me banharia com a água em que ela lavou os seus pés.

Ivan-tsarévitche pegou a bela donzela pela sua branca mão, a levou até o lugar onde o cabo estava pendurado e fez um sinal para Biélyi Poliánin. Ele segurou o cabo e começou a puxá-lo, puxou, puxou e trouxe para fora o tsarévitche e a bela donzela. “Olá, Biélyi Poliánin - disse Ivan-tsarévitche - eis uma noiva para você. Viva, divirtase e não se preocupe com nada! E eu irei para o reino do dragão.” Montou em seu poderoso cavalo, despediu-se de Biélyi Poliánin e da noiva dele e partiu para além das trinta terras. Nem longo nem curto, nem pouco nem muito, o tempo passou - pois um conto é contado num ato, mas um ato é demorado - ele chegou então ao reino do dragão, matou o tsar-dragão, libertou a bela princesa do cativeiro e se casou com ela; depois voltou para casa e com a sua jovem esposa passou a viver tranqüilo e feliz e a prosperar.

\section{Doa}

\footnotetext{
${ }^{5}$ No original: za trideviát zemiél, $v$ tridessiátom gossudárstve. Trídeviat, antiga forma para o numeral "vinte e sete"; tridessiátyi é uma antiga forma para "trigésimo". Porém, são usados em conjunto na expressão dada, formando uma forma fixa típica do folclore com o sentido de algum lugar muito, muito longe.

${ }^{6}$ No original koroliévna. Os termos korol (rei), koroliéva (rainha) e koroliévitch (príncipe) são geralmente usados para os monarcas não russos, tsares.
} 


\section{Conto sobre o jovem valente, as maçãs da juventude e a água da vida II $^{1}$ (172)}

Era uma vez um tsar e uma tsarina que tinham três filhos. Um dia, o tsar enviou os seus filhos em busca da juventude dele. Os tsarévitches então partiram em viagem e na estrada encontraram um poste do qual saíam três caminhos. No poste estava escrito: o cavaleiro que for pela direita será bem-alimentado, mas o seu cavalo terá fome; o cavaleiro que for pela esquerda terá fome, mas o seu cavalo será bem-alimentado; e aquele que for reto perderá a vida. O tsarévitche mais velho foi pela direita, o do meio, pela esquerda, e o mais novo, reto. Nem muito nem pouco, o irmão mais novo seguiu até que surge diante dele um profundo fosso. Sem pensar muito em como atravessá-lo; benzeu-se, açoitou o cavalo, pulou para o outro lado e então viu, ao lado de uma densa floresta, uma isbazinha sobre pernas de galinha. "Isbazinha, isbazinha! Vire de costas para a floresta e de frente para mim.” A isbazinha se virou. Ivan-tsarévitche entrou e lá estava a Baba-Iagá sentada. “Fu, fu! - falou ela - até hoje nunca se viu nem se sentiu o cheiro de um russo por aqui, e eis que agora surge um e na minha boca quer se atirar. $\mathrm{E}$ então, jovem valente, você está fugindo de uma tarefa ou procurando uma tarefa?” “Ah, sua velha rabugenta! Você não deveria estar falando nem eu escutando. Primeiro, me dê algo para beber e para comer e depois me faça perguntas.” Ela lhe deu algo para beber e comer, o fez contar tudo e lhe deu o seu cavalo alado: "Vá, meu caro, até a minha irmã do meio.”

Ele seguiu por um tempo nem longo nem curto e então viu uma isbazinha, entrou e lá estava a Baba-Iagá sentada. "Fu, fu! - falou ela - até hoje nunca se viu nem se sentiu o cheiro de um russo por aqui, e eis que agora surge um e na minha boca quer se atirar. E então, jovem valente, você está procurando uma tarefa ou fugindo de uma tarefa?” - “Ah, tia! Dê-me algo para beber e para comer e depois me faça perguntas.” Ela lhe deu algo para beber e comer e então começou a interrogá-lo: “Qual destino o trouxe a estas terras tão distantes?” - “Meu pai me enviou em busca da juventude dele.” - “Então, troque o seu cavalo pelo meu melhor e vá até a minha irmã mais velha.”

O tsarévitche imediatamente partiu em viagem; ele seguiu por um tempo nem longo nem pouco e novamente viu uma isbazinha sobre pernas de galinha. "Isbazinha,

\footnotetext{
${ }^{1}$ Mesmo caso do conto Ivachko e a bruxa. Este conto é uma variante pertencente a um grupo formado por outras sete. O título apresentado corresponde à primeira variante. Assim como no caso do conto anterior, o título atribuído à primeira vale para todo o grupo.
} 
isbazinha! Fique de frente para mim e de costas para a floresta.” A isbazinha girou. Ele entrou e lá estava a Baba-Iagá sentada. "Fu, fu! - falou ela - até hoje nunca se viu nem se sentiu o cheiro de um russo por aqui, e eis que agora surge um e na minha boca quer se atirar. E então, jovem valente, você está procurando uma tarefa ou fugindo de uma tarefa?” - “Ah, sua velha rabugenta! Você não me deu nada para comer nem para beber e já está me fazendo perguntas.” A Baba-Iagá lhe deu algo para comer e para beber, o fez contar tudo e lhe deu um cavalo melhor que os outros dois: "Vá com Deus! Perto daqui há um reino, não entre nele pelos portões, eles são guardados por leões, você deve chicotear bem o seu cavalo e saltar direto sobre a paliçada, mas tenha cuidado para não esbarrar nas cordas, senão todo o reino irá se alvoroçar: e aí você não sairá vivo de lá! Assim que você saltar a cerca, vá direto para o palácio, para o quarto dos fundos, abra a porta bem devagarzinho e você verá a tsar-donzela ${ }^{2}$ dormindo, debaixo do travesseiro dela está escondido um frasquinho com a água da vida. Pegue esse frasquinho e saia imediatamente, não fique contemplando a beleza dela.”

O tsarévitche fez tudo como a Baba-Iagá lhe havia ensinado. Só não conseguiu se conter em uma coisa e acabou desejando com avidez a bela donzela ... ${ }^{3}$, montou no seu cavalo, mas as pernas do cavalo se dobraram ao pular a paliçada e esbarraram na corda. Num instante, todo o reino despertou, a tsar-donzela se levantou e ordenou que lhe selassem o cavalo. A Baba-Iagá já sabia o que tinha acontecido com o jovem valente e estava preparada para as perguntas; assim que ela se despediu do tsarévitche, a tsardonzela chegou voando, encontrou a Baba-Iagá toda despenteada e perguntou: “Como você se atreveu a deixar esse canalha chegar até o meu reino? Ele esteve em minha casa, bebeu o kvas $^{4}$ e nem o tampou" ${ }^{5}$ - "Mas, minha querida tsar-donzela! Será que você não percebeu como os meus cabelos estão despenteados, eu lutei com ele por muito tempo, mas não consegui vencê-lo.” As outras duas Babas-Iagás falaram a mesma coisa. A tsar-donzela foi atrás do tsarévitche e estava quase o alcançando quando ele saltou sobre o fosso. A tsar-donzela disse-lhe em sua direção: "Espere-me por três anos, eu chegarei em um navio.”

\footnotetext{
${ }^{2}$ Tsar-donzela, além de indicar o seu posto de governante, mostra também a sua superioridade entre todas as outras donzelas.

${ }^{3}$ As reticências aqui são muito bem aplicadas, como uma maneira de apresentar o suspense da cena, suscitando que houve um enlace sexual.

${ }^{4}$ Kvas, bebida russa gasosa, preparada a partir da fermentação natural do pão feito de centeio, cevada ou trigo, às vezes é aromatizada com frutas. Seu grau alcoólico nunca é superior a $2 \%$, sendo consumido por crianças e mulheres.

5 "Bebeu o kvas e nem o tampou." Expressão de sentido erótico em que a heroína reclama da atitude daquele que a desonrou.
} 
De tanta alegria, o tsarévitche não percebeu que se aproximava do poste e acabou virando à esquerda. Ele chegou a uma montanha de prata, em cima da montanha havia uma tenda, próximo à tenda, um cavalo comendo painço ${ }^{6}$ e bebendo melaço, e dentro da tenda estava deitado um jovem valente, que era o seu irmão e que lhe disse: "Vamos procurar o nosso irmão mais velho." Selaram os seus cavalos e tomaram o caminho da direita, chegaram a uma montanha dourada, em cima da montanha havia uma tenda, próximo à tenda, um cavalo comendo painço e bebendo melaço, e dentro da tenda estava deitado um jovem valente, o irmão mais velho deles. Eles o acordaram e foram todos juntos até o poste onde os três caminhos se juntavam, lá se sentaram para descansar. Os dois irmãos mais velhos começaram a interrogar o menor: "Você encontrou a juventude do nosso pai?” - “Encontrei.” - “E como é que foi? Onde?” Ele lhes contou tudo o que tinha acontecido, deitou sobre a relva e adormeceu. Os irmãos o cortaram em pedacinhos e os espalharam pela vasta planície, pegaram o frasquinho com a água da vida e foram ao encontro do pai.

De repente, chegou o pássaro de fogo ${ }^{7}$, recolheu todos os pedaços espalhados, os juntou na forma como deve ser o corpo de um humano, depois trouxe na boca a água da morte, a borrifou nele e todos os pedaços se uniram; trouxe então a água da vida, a borrifou e o tsarévitche voltou à vida, levantou-se e disse: "Nossa, quanto tempo eu dormi!” E o pássaro de fogo respondeu: "E se não fosse eu, você dormiria um sono profundo por toda a eternidade.” O tsarévitche lhe agradeceu e foi para casa; seu pai não se alegrou em vê-lo e o expulsou, e assim o tsarévitche ficou por três anos vagando pelos cantos.

Três anos se passaram, chegou então o navio da tsar-donzela. Ela mandou uma carta para o tsar para que ele lhe enviasse o culpado e, se ele se opusesse, ela destruiria todo o reino e o reduziria a cinzas. O tsar lhe enviou o seu filho mais velho que foi até o navio. Dois meninos o viram, os dois eram filhos da tsar-donzela e começaram a perguntar à sua mãe: “Este é o nosso pai?” - “Não, este é o tio de vocês.” - “E como vamos recebê-lo?” - “Pegue cada um de vocês um chicote e o mande embora.” O irmão mais velho voltou para casa, desenxavido. Com as mesmas ameaças, a tsar-donzela

\footnotetext{
${ }^{6}$ No original beloiáraia pchenítsa. Segundo dicionário de Dal, antiga designação para turiétskoe pchenó, isto é, milho-da-itália ou painço.

${ }^{7}$ No original jar-ptítsa, pássaro mágico do qual apenas uma pena é capaz de iluminar um cômodo como se estivesse repleto de luz. Segundo Meletínski, "a cor dourada do pássaro de fogo e da sua gaiola está ligada ao fato de esse pássaro vir do outro ("trigésimo") reino, de onde vem tudo que tem a cor dourada." (Dicionário de Mitologia in http://myths.kulichki.ru/).
} 
continuou exigindo a entrega do culpado, o tsar lhe enviou o seu outro filho, e com ele aconteceu o mesmo que havia acontecido com o primeiro.

Então, o tsar ordenou que procurassem o tsarévitche caçula e, assim que ele foi encontrado, o pai quis enviá-lo até o navio ao encontro da tsar-donzela. E ele falou: “Só irei quando for construída uma ponte de cristal daqui até o navio, e sobre a ponte houver as mais diversas iguarias e bebidas.” Não havia o que fazer, a ponte foi construída, muitas iguarias preparadas, vinho ${ }^{8}$ e hidroméis providenciados. O tsarévitche reuniu seus amigos e disse: "Venham comigo, comam e bebam até se fartarem.” E, enquanto ele atravessava a ponte, os meninos gritaram: “Mamãe, quem é este?” - “Este é o pai de vocês.” - “Como vamos recebê-lo?” - “Peguem-no pela mão e tragam-no até mim.” Então, eles se beijaram, se abraçaram e se acariciaram. Depois, foram até o tsar e lhe contaram tudo o que havia acontecido. O tsar expulsou os irmãos mais velhos e ele e o caçula passaram a viver tranqüilos e felizes e a prosperar.

\section{6}

\footnotetext{
${ }^{8}$ Ver nota 18, conto 3, p. 104.
} 


\section{Conto sobre o jovem valente, as maçãs da juventude e a água da vida III $^{1}$ (173)}

Em certo reino, em certo estado, vivia um tsar que tinha três filhos: dois eram sensatos, e o terceiro, tolo. Um dia, o tsar sonhou que, além das trinta terras, no trigésimo estado ${ }^{2}$, havia uma bela donzela de cujas mãos e pés fluía água: quem bebesse dessa água ficaria trinta anos mais jovem. O tsar era muito velho, chamou seus filhos e os seus conselheiros e lhes perguntou: “Quem conseguiria desvendar o meu sonho?” Os conselheiros responderam ao tsar: "Vossa majestade, ver não vimos, mas ouvir, ouvimos sobre essa bela donzela! Mas como chegar até ela, nós não sabemos.” O filho mais velho, então, Dmitri-tsarévitche, se pôs a falar: "Pai! Dê-me a sua benção para eu partir para os quatro cantos da terra, conhecer pessoas e ser conhecido e saber sobre a bela donzela. O pai o abençoou e disse: "Pegue o quanto você quiser de dinheiro e o quanto você precisar de tropas.”

Dmitri-tsarévitche pegou cem mil soldados e partiu em viagem; passou um dia, passou uma semana, passou um mês e dois e três, e a todos que ele perguntava, ninguém sabia nada sobre a bela donzela; então ele acabou chegando a um lugar tão deserto, que era só céu e terra. Apressou o seu cavalo para prosseguir e eis que se deparou com uma montanha muito, muito alta, tão alta que os olhos não conseguiam alcançar o seu topo! Com dificuldade, ele subiu nessa montanha e lá encontrou um velho, muito velho, de cabelos brancos. “Olá, vovô!” - “Olá, jovem valente!” - “Você está fugindo de uma tarefa ou procurando uma tarefa?” - “Eu a estou procurando.” - “E o que você quer, então?” - “Eu ouvi dizer que além das trinta terras, no trigésimo estado, há uma bela donzela, das suas mãos e dos seus pés flui a água que cura: quem conseguir beber dessa água, ficará trinta anos mais jovem.” - “Eh, irmão, mas você não vai conseguir chegar até lá!” - “Por que não?” - “Porque no caminho para lá há três largos rios, e nestes rios há três balsas: na primeira balsa, cortarão o seu braço direito; na segunda, a sua perna esquerda; e na terceira, arrancarão a sua cabeça.” Entristecido, Dmitri-tsarévitche abaixou a sua impetuosa cabeça entre os seus fortes ombros e começou a pensar: "É a cabeça do meu pai ou a minha que devo poupar? É melhor eu ir embora.” Desceu da montanha, voltou para a casa do pai e lhe disse: “Não, pai, não consegui descobrir nada, sobre a bela donzela nunca ninguém ouviu falar!”

\footnotetext{
${ }^{1}$ Ver nota 1, do conto anterior, p. 111.

${ }^{2}$ Ver nota 5, conto 4, p. 110.
} 
Então, o filho do meio, Vassili-tsarévitche, começou a pedir: "Pai! Dê-me a sua benção, talvez eu a encontre!” - “Vá, meu filho!” Vassili-tsarévitche pegou cem mil soldados e partiu em viagem; passou um dia, passou uma semana, passou um mês e dois e três, e então ele acabou chegando a um lugar tão deserto que era só floresta e pântano. Lá, encontrou a Baba-Iagá, perna de osso, b... seca ${ }^{3}$. “Olá, Baba-Iagá, perna de osso!” “Olá, jovem valente! Você está fugindo de uma tarefa ou procurando uma tarefa?” “Eu a estou procurando. Eu ouvi dizer que além das trinta terras, no trigésimo estado, há uma bela donzela, das suas mãos e dos seus pés flui a água que cura.” - “Tem, meu caro, tem, sim! Só que você não conseguirá chegar até lá!” - “E por que não?” "Porque no caminho para lá há três balsas: na primeira balsa, cortarão o seu braço direito; na segunda, a sua perna esquerda; e na terceira, a sua cabeça.” Vassilitsarévitche ficou pensativo: "É a cabeça do meu pai que devo poupar ou é a minha que devo preservar? É melhor eu ir embora, enquanto está tudo bem.” Voltou e disse ao pai: “Não, pai, não consegui descobrir nada, sobre a bela donzela nunca ninguém ouviu falar!”

O filho caçula, Ivan-tsarévitche, começou então a pedir: "Pai! Dê-me a sua benção, quem sabe eu não a encontro?” O pai o abençoou: “Vá, meu querido filho! Pegue o quanto você precisar de soldados e dinheiro." - "Eu não preciso de nada, somente me dê um bom cavalo e uma espada invencível.” Ivan-tsarévitche montou no cavalo, pegou sua espada invencível e partiu em viagem, passou um dia, passou uma semana, passou um mês e dois e três, e então ele acabou chegando a um lugar onde o seu cavalo ficou com água até os joelhos e mato até o peito, e onde ele próprio, jovem valente, não tinha nada para comer. Ele viu então uma isbazinha sobre pernas de galinha, entrou e na isbazinha estava sentada a Baba-Iagá, perna de osso. “Olá, vovó!” “Olá, Ivan-tsarévitche! Você está fugindo de uma tarefa ou procurando uma tarefa?” "Mas que tarefa, que nada! Eu estou indo para além das trinta terras, no trigésimo estado, dizem que lá há uma bela donzela, das suas mãos e dos seus pés flui a água que cura.” - “Tem sim, meu caro! Embora eu não a tenha visto, já ouvi falar sobre ela; só que você não conseguirá chegar até lá!” - “Por que não?” - “Porque no caminho para lá há três balsas: na primeira balsa, cortarão o seu braço direito; na segunda, a sua perna esquerda; e na terceira, a sua cabeça.” - “Mas, vovó, uma cabeça não é nada. Eu irei, e seja o que Deus quiser.” - “Eh, Ivan-tsarévitche, melhor você voltar, você ainda é muito

\footnotetext{
${ }^{3}$ No original $j . .$. jílinaia. Acredita-se que o j... se refere à palavra jópa, isto é, bunda, e que o adjetivo jílinyi é o mesmo que jíl'nyi: de tendão, por isso, optou-se por seca.
} 
jovem, nunca esteve em lugares perigosos, nem passou por grandes medos.” - "Não, vovó, se você pegou no cordame, não fale que não tem força!”

Despediu-se da Baba-Iagá e prosseguiu: passou um dia, dois e no terceiro ele chegou até a primeira balsa. Os balseiros estavam dormindo do outro lado. "O que eu faço? - pensou Ivan-tsarévitche, se eu gritar para sempre os deixarei surdos, se eu assoviar, afundarei a balsa.” Ele então assobiou mas não com toda a sua força, os balseiros num pulo se levantaram e o levaram para o outro lado do rio. - "O que vocês querem pelo trabalho, irmãos?” - “Dê o seu braço direito.” - “Ah, não, do meu braço eu mesmo preciso.” O tsarévitche girou sua espada para a direita e para a esquerda e acabou com todos os balseiros, montou no seu cavalo e seguiu. Nas outras duas balsas, ele se livrou do mesmo jeito. Eis então que ele se aproximou do trigésimo estado, na fronteira estava um homem selvagem, alto como o topo da floresta, largo como uma enorme meda, segurava nas mãos um carvalho maciço. O gigante falou então para Ivantsarévitche: "Para onde você está indo, seu verme?” - “Estou indo para o trigésimo reino, quero ver a bela donzela, de cujas mãos e pés verte a água que cura." - "Você? Como, seu nanico!? Eu protejo o reino dela há cem anos, e já vieram até aqui fortes e poderosos bogatyrí, com os quais você nem se compara e todos eles morreram da minha forte mão. E você, seu verme, quem pensa que é?”

O tsarévitche percebeu que não haveria acordo com o gigante e deu meia-volta. Andou, andou e foi parar numa densa floresta. Na floresta havia uma isbazinha, e na isbazinha estava sentada uma velha, muito velha, ela viu o jovem valente e falou: “Olá, Ivan-tsarévitche! Para que você veio até aqui?” Ele lhe contou tudo, sem esconder nada. A velha lhe deu uma poção mágica e um novelinho e disse: "Vá até a vasta planície, faça uma fogueira e jogue essa poção no fogo, mas cuidado, não fique contra o vento. Esta poção mágica fará o gigante dormir profundamente, você então corta a cabeça dele, joga o novelinho no chão e vai atrás dele. O novelinho o levará até o lugar onde reina a bela donzela, ela vive em um grande palácio de ouro e sempre sai com sua tropa para os campos verdes para se divertir: nove dias ela passeia, e depois nove dias ela dorme profundamente.” Ivan-tsarévitche agradeceu à velha e foi para a vasta planície, lá fez a fogueira e jogou no fogo a poção mágica. Um vento forte puxou a fumaça para o lado onde o homem selvagem fazia guarda; seus olhos começaram a ficar pesados e ele se deitou na terra úmida e dormiu muito, muito profundamente. Ivan-tsarévitche cortou a sua cabeça, jogou o novelinho e pôs-se a segui-lo. 
Seguiu, seguiu e avistou um palácio de ouro, desviou então do seu caminho, deixou o seu cavalo sobre o capim e se enfiou entre os arbustos. Assim que se escondeu, do palácio de ouro, levantou-se uma nuvem de poeira: era a bela donzela que saía com as suas tropas para se divertir nos campos verdes. O tsarévitche vê que toda a sua tropa é formada somente por donzelas: uma mais bela que a outra! Mas entre todas, a mais bela, a mais admirável era a própria tsarina. Nove dias, ela passeou nos campos verdes, e o tsarévitche não tirou os olhos dela e não se cansou de olhá-la. No décimo dia, ele foi para o palácio de ouro: sobre um colchão de plumas, a bela jovem estava deitada e dormia profundamente, das suas mãos e dos seus pés fluía a água que cura, junto dela dormia também a sua fiel tropa. Ivan-tsarévitche pegou dois frasquinhos da água que cura e então não conseguiu conter o seu coração de jovem e feriu a donzelice da bela, depois saiu do palácio, montou em seu bom cavalo e voltou para casa.

A bela donzela dormiu por nove dias e nove noites e quando acordou, ficou terrivelmente enfurecida, começou a bater os pés no chão e com uma voz cortante gritou: "Quem era o canalha que esteve aqui? Bebeu meu kvas e nem o tampou", Montou em sua veloz égua e foi atrás de Ivan-tsarévitche: a égua corria e a terra tremia! Ela alcançou o jovem valente, golpeou com sua espada e o atingiu diretamente no peito. O tsarévitche caiu na terra úmida, seus olhos claros começaram a se fechar e o seu sangue escarlate a endurecer. A bela jovem olhou para ele e foi tomada por uma grande piedade: pois não se achava um jovem tão belo assim no mundo! Ela então encostou sua mão branca sobre a ferida dele e a umedeceu com a água que cura - de repente, a ferida se fechou e Ivan-tsarévitche se levantou são e salvo. "Você me tomaria como sua esposa?” - “Sim, bela donzela!” - “Então, vá para casa e me espere por três anos.”

Ivan-tsarévitche despediu-se da sua noiva prometida e seguiu o seu caminho. Aproximava-se do seu reino, mas seus irmãos mais velhos colocaram guardas em todos os lugares para que ele não conseguisse chegar até o seu pai. Os guardas imediatamente avisaram que o tsarévitche estava vindo; os irmãos mais velhos o encontraram no caminho, o embebedaram, tiraram o seu frasquinho com a água que cura e jogaram o caçula em um abismo. O tsarévitche foi parar no outro mundo... ${ }^{5}$

\footnotetext{
${ }^{4}$ Ver nota 5, do conto 5, p. 112.

${ }^{5}$ Originalmente o texto termina aqui. Na nota ao texto inacabado, Afanássiev apresentou os seguintes episódios: Ivan-tsarévitche é salvo com a ajuda de um grande pássaro que o leva nas suas asas para o outro mundo (ver conto O bicho marta - 132), depois o texto termina da mesma forma como o seu antecessor (172). Seguindo essas instruções, terminou-se o conto. Os três últimos parágrafos pertencem ao conto 172, conforme indicado pela nota 6 .
} 
O tsarévitche andou, andou. De repente, levantou-se uma tempestade, raios começaram a brilhar, trovões a ressoar e a chuva a cair. Ele foi então até uma árvore para se esconder debaixo dela, quando viu que nos galhos havia uns pequenos passarinhos completamente molhados, ele tirou a sua roupa e os cobriu e depois se sentou sobre a árvore. E então, chegou um pássaro tão grande que escondeu a luz do dia, deixando o que estava escuro ainda mais escuro. Este pássaro era a mãe dos passarinhos que o tsarévitche tinha coberto.

Ao chegar, tal pássaro percebeu que seus filhotinhos estavam cobertos e perguntou: “Quem cobriu meus filhotes?”, notou então o tsarévitche e continuou: “Foi você que fez isso? Eu agradeço. Pode me pedir o que você quiser, qualquer coisa, e eu o farei!” Ele então disse: “Leve-me para o outro mundo.” O pássaro então falou: “Faça um grande barril, cace algo e jogue lá dentro e a outra metade encha de água, para que eu tenha o que comer." O tsarévitche fez tudo. Após ter colocado o barril sobre si, e o tsarévitche ter subido nas suas costas, o pássaro começou a voar.

Nem muito nem pouco, eles voaram, e o pássaro o trouxe para o outro mundo ${ }^{6}$. O tsarévitche agradeceu e foi para casa; seu pai não se alegrou em vê-lo e o expulsou, e assim o tsarévitche ficou por três anos vagando pelos cantos.

Três anos se passaram, chegou então o navio da tsar-donzela. Ela mandou uma carta para o tsar para que ele lhe enviasse o culpado e, se ele se opusesse, ela destruiria todo o reino e o reduziria a cinzas. O tsar lhe enviou o seu filho mais velho que foi até o navio. Dois meninos o viram, os dois eram filhos da tsar-donzela e começaram a perguntar à sua mãe: “Este é o nosso pai?” - “Não, este é o tio de vocês.” - “E como vamos recebê-lo?” - "Pegue cada um de vocês um chicote e o mande embora.” O irmão mais velho voltou para casa, desenxavido. Com as mesmas ameaças, a tsar-donzela continuou exigindo a entrega do culpado, o tsar lhe enviou o seu outro filho, e com ele aconteceu o mesmo que havia acontecido com o primeiro.

Então, o tsar ordenou que procurassem o tsarévitche caçula e, assim que ele foi encontrado, o pai quis enviá-lo até o navio ao encontro da tsar-donzela. E ele falou: "Só irei quando for construída uma ponte de cristal daqui até o navio, e sobre a ponte houver as mais diversas iguarias e bebidas.” Não havia o que fazer, a ponte foi construída, muitas iguarias preparadas, vinho e hidroméis providenciados. O tsarévitche reuniu seus amigos e disse: “Venham comigo, comam e bebam até se fartarem.” E, enquanto ele

\footnotetext{
${ }^{6}$ Fim do trecho do conto $O$ bicho marta.
} 
atravessava a ponte, os meninos gritaram: “Mamãe, quem é este?” - “Este é o pai de vocês.” - “Como vamos recebê-lo?” - "Peguem-no pela mão e tragam-no até mim.” Então, eles se beijaram, se abraçaram e se acariciaram. Depois, foram até o tsar e lhe contaram tudo o que havia acontecido. $\mathrm{O}$ tsar expulsou os irmãos mais velhos e ele e o caçula passaram a viver tranqüilos e felizes e a prosperar.

200 


\section{7. $O$ tsar-urso (201)}

Era uma vez um tsar e uma tsarina que não tinham filhos. Um dia, o tsar foi à caça de bons animais e de pássaros migratórios. Fazia muito calor e ele queria beber água, viu ao lado um poço, aproximou-se, debruçou-se e assim que ia beber, o tsar-urso o segurou pela barba. "Me larga." - pediu o tsar. "Só o soltarei, se você me der aquilo que tem na sua casa e você não sabe.” - “O que eu teria em casa e não sei - pensou o tsar acho que sei tudo o que tem lá... É melhor - falou - eu lhe dar um rebanho de vacas.” “Não, não quero nem dois rebanhos.” - “Mas, então pegue uma manada de cavalos.” "Não, não preciso nem de duas manadas, me dê aquilo que tem na sua casa e você não sabe.”

O tsar concordou, teve a sua barba solta e foi para casa. Entrou no palácio, e sua mulher tinha dado à luz gêmeos: Ivan-tsarévitche e Maria-tsarevna, eis o que ele não sabia que tinha em casa. O tsar ergueu os braços e começou a chorar amargamente. "Por que você está se consumindo tanto?” - perguntou a tsarina. - “Como não estaria? Eu dei os meus filhinhos ao tsar-urso.” - “Como foi isso?” - “Assim e assim” - contou o tsar. “Mas, nós não os entregaremos.” - “Ah, não há como evitar! Ele irá destruir todo o reino e irá pegá-los de qualquer jeito.”

Eles pensaram e pensaram o que fazer. E então tiveram a idéia de cavar um buraco muito profundo e arrumá-lo e enfeitá-lo como se fosse um palácio, para lá levaram todos os tipos de provisões para que houvesse o que comer e beber. Depois, colocaram nesse buraco os seus filhos, fizeram em cima dele um teto e o cobriram com terra, deixando a superfície lisa, lisa.

Logo depois, o tsar e a tsarina morreram, mas os seus filhos continuavam a crescer e crescer. Finalmente, o tsar-urso veio atrás deles, olhou de um lado, olhou de outro: não havia ninguém! O palácio estava vazio. Ele andou, andou, percorreu toda a casa e pensou: “Quem poderia me dizer onde os filhos do tsar se meteram?” De repente, ele notou um formão encravado na parede. "Formão, formão, diga-me, onde estão os filhos do tsar?” - perguntou o tsar-urso. "Leve-me para o quintal e me jogue no chão, no lugar onde eu cravar, você deve cavar.” O tsar-urso pegou o formão, o levou para o quintal e o jogou no chão; o formão rodopiou, girou e cravou-se no exato lugar onde estavam escondidos Ivan-tsarévitche e Maria-tsarevna. O urso cavou a terra com as patas, quebrou o teto e disse: “Ah, Ivan-tsarévitche, ah, Maria-tsarevna, então é aí que 
vocês estão!... Pensavam que iam se esconder de mim! O pai e a mãe de vocês me enganaram e por isso eu irei comer vocês.” - “Ah, tsar-urso, não nos coma, nosso pai nos deixou muitas galinhas e gansos e muitos outros bens, há muito com o que você se deliciar.” - “Então, está bem! Montem em mim, vocês serão meus servos.”

Eles montaram, e o tsar-urso os levou em direção a montanhas tão íngremes e altas que chegavam até o céu; o lugar era completamente deserto, ninguém morava lá. “Nós queremos comer e beber.” - falaram Ivan-tsarévitche e Maria-tsarevna. "Eu irei correndo conseguir algo para vocês comerem e beberem, enquanto isso fiquem aqui e descansem." - respondeu o urso. O urso foi correndo em busca de comida, e o tsarévitche e a tsarevna ficaram em prantos. De repente, não se sabe de onde, surgiu um falcão brilhante ${ }^{1}$, bateu as asas e pronunciou as seguintes palavras: "Ah, Ivantsarévitche e Maria-tsarevna, que destino os trouxe aqui?” Eles lhe contaram. - "Para que o urso pegou vocês?" - "Para servi-lo em tudo.” - "Vocês querem que eu os leve daqui? Subam nas minhas asas.” Eles subiram, o falcão brilhante voou acima das árvores imóveis e abaixo das nuvens andantes, indo para países distantes. Mas, nesse momento, o tsar-urso chegou correndo, viu o falcão no alto do céu, bateu a cabeça na terra úmida e com as chamas queimou as asas do falcão. As asas do falcão se queimaram, e ele pôs o tsarévitche e a tsarevna na terra. "Ah - disse o urso - vocês queriam fugir de mim, eu irei comer vocês até os seus ossinhos por isso!” - "Não, não nos coma, tsar-urso, nos iremos servi-lo fielmente.” O urso os perdoou e os levou para o seu reino; as montanhas ficavam cada vez mais altas e íngremes.

Nem muito nem pouco, o tempo passou, e Ivan-tsarévitche falou “Ah, eu quero comer!” - "E eu também!” - falou Maria-tsarevna. O tsar-urso foi correndo em busca de comida e ordenou severamente que eles não saíssem do lugar. Eles se sentaram sobre a relva macia e as suas lágrimas escorriam. De repente, não se sabe de onde, surgiu uma águia, que desceu das nuvens e perguntou: “Ah, Ivan-tsarévitche e Maria-tsarevna, que destino os trouxe aqui?” Eles lhe contaram. "Vocês querem que eu os leve daqui?” "Você?! Como? O falcão brilhante já tentou e não conseguiu, você também não conseguirá!” - “O falcão é um pássaro pequeno, eu vôo mais alto do que ele, subam em minhas asas.” O tsarévitche e a tsarevna subiram. A águia bateu as asas e voou mais alto ainda. O urso chegou correndo e viu a águia no alto do céu, bateu a cabeça na terra úmida e queimou as asas dela. A águia pousou o tsarévitche e a tsarevna na terra. “Ah,

\footnotetext{
${ }^{1}$ Ver nota 2, do conto 4, p. 105.
} 
vocês novamente queriam fugir! - disse o urso. - É agora que eu irei comer vocês!” "Não, por favor, não nos coma, a águia nos seduziu! Nós iremos lhe servir fiel e honestamente.” O tsar-urso os perdoou pela última vez, deu-lhes de comer e beber e os levou para longe...

Nem muito nem pouco, o tempo passou. "Ah - falou Ivan-tsarévitche - quero comer!” - “E eu também!” - falou Maria-tsarevna. O tsar-urso os deixou e foi correndo em busca de comida. Eles se sentaram sobre a relva macia e choraram. De repente, não se sabe de onde, surgiu um bezerro-cag....inho ${ }^{2}$, que balançou a cabeça e perguntou: “Ivan-tsarévitche e Maria-tsarevna, que destino os trouxe aqui?” Eles lhe contaram. “Vocês querem que eu os leve daqui?” - "Você?! Como? O falcão e a águia já tentaram e não conseguiram, não é você que conseguirá!”, e choravam tanto que mal conseguiam falar. “Os pássaros não levaram, mas eu vou levar! Subam nas minhas costas.” Eles subiram, e o bezerro-cag...inho pôs-se a correr, mas não muito rápido. O urso viu que o tsarévitche e tsarevna estavam fugindo e começou a persegui-los. "Ah, bezerrocag...inho - gritaram os filhos do tsar - o urso está correndo atrás de nós.” - “Ele está longe?” - “Não, perto.”

O urso deu um salto e estava quase os agarrando, quando o bezerro fez força... e tampou os olhos do urso. O urso correu para o mar azul para lavar os olhos, enquanto o bezerro-cag...inho se afastava cada vez mais dele! O tsar-urso se lavou e começou a persegui-los de novo. “Ah, bezerro-cag...inho, o urso está correndo atrás de nós.” - “Ele está longe?” - “Ai, não, perto.” O urso deu um salto, e o bezerro novamente fez força... e tampou os olhos do urso. Enquanto o urso correu para lavar os olhos, o bezerro se afastava cada vez mais dele! E pela terceira vez, ele tampou os olhos do urso e depois disso deu ao Ivan-tsarévitche um pente e uma toalha e falou: “Quando o tsar-urso estiver quase nos alcançando, da primeira vez, jogue o pente, e da segunda, balance a toalha."

O bezerro-cag...inho se afastava cada vez mais e mais. Ivan-tsarévitche olhou para trás e viu o tsar-urso se aproximando, quase os agarrando. Pegou o pente e jogou atrás de si - de repente, nasceu e se levantou uma floresta tão espessa e densa que por ali nenhum pássaro conseguia voar, nenhum animal passar, nenhuma pessoa caminhar, nenhum cavalo galopar. O urso começou a roer e roer até que finalmente conseguiu

\footnotetext{
${ }^{2}$ No original $d r . . . n o k$. Pelo contexto, acredita-se que significa dristunók, do verbo dristát', isto é, estar com diarréia. Considerando o sufixo "ok" como indicador de diminutivo, optou-se aqui pela tradução bezerro-cagãozinho.
} 
abrir uma passagem bem estreita, lançou-se através da densa floresta e recomeçou a perseguição; mas os filhos do tsar já estavam longe, longe! Mesmo assim, o urso já estava quase os alcançando, Ivan-tsarévitche olhou para trás e balançou a toalha - de repente, formou-se um lago de fogo muito, muito largo! As ondas batiam de uma ponta a outra, o tsar-urso ficou e ficou por um tempo na margem e depois voltou para casa; e o bezerro-cag...inho com Ivan-tsarévitche e Maria-tsarevna chegaram até uma clareirinha.

Nessa clareirinha, havia uma casa grande e boa. "Eis uma casa para vocês! - falou o bezerro - vivam aí sem preocupações. Mas agora façam no quintal uma fogueira, me matem e nela me queimem.” - “Ah, falou os filhos do tsar - Por que iremos matá-lo? É melhor você viver conosco, nós iremos cuidar de você, lhe daremos grama fresca para comer e água da fonte para beber.” - "Não, me queimem e com as minhas cinzas semeiem três canteiros: de um saltará um cavalo, do outro, um cachorrinho e, do terceiro, brotará uma macieira. O cavalo, Ivan-tsarévitche, é para você montar, e o cachorrinho é para acompanhá-lo na caça.” E assim eles fizeram.

Eis que um dia, Ivan-tsarévitche decidiu caçar; despediu-se da irmã, montou no cavalo e foi para a floresta; matou um ganso, matou um pato, capturou um lobinho e o levou para casa. Ivan-tsarévitche percebeu que tinha sorte na caça e novamente foi caçar, abateu diversos pássaros e capturou um ursinho. Da terceira vez, Ivan-tsarévitche preparou-se para caçar, mas esqueceu de levar o seu cachorrinho. Enquanto isso, Mariatsarevna foi lavar roupa. Estava indo e do outro lado do lago de fogo chegou voando até a margem um dragão de seis cabeças, que se transformou em um belo jovem, notou a tsarevna e docemente falou: “Olá, bela donzela!” - “Olá, jovem valente!” - “Eu ouvi dos anciões que outrora este lago não existia, mas se houvesse uma ponte alta que o cruzasse, eu atravessaria até aí e me casaria com você.” - “Espere, agora mesmo haverá uma ponte aqui." - respondeu-lhe Maria-tsarevna e lançou a toalha. No mesmo minuto, a toalha se estendeu como um arco e prendeu-se do outro lado do lago formando uma alta e bela ponte. O dragão atravessou a ponte, transformou-se na sua forma anterior, trancou o cachorrinho de Ivan-tsarévitche com um cadeado e jogou a chave no lago. Depois, agarrou a princesa e fugiu.

Ivan-tsarévitche voltou da caça e não encontrou a sua irmã, seu cachorrinho uivava trancafiado, viu a ponte que atravessava o lago e falou: "Pelo visto, o dragão levou a minha irmãzinha!” e saiu em sua busca. Andou, andou e na vasta planície 
encontrou uma isbazinha ${ }^{3}$ sobre pernas de galinha e calcanhares de cachorro. "Isbazinha, isbazinha! Vire de costas para a floresta e de frente para mim.” A isbazinha virou. Ivan-tsarévitche entrou e na isbazinha estava deitada de um canto ao outro a Baba-Iagá, perna de osso, com o nariz encravado no teto. "Fu, fu! - falou ela - até hoje nunca se sentiu o cheiro de um russo por aqui, e eis que agora surge um e no meu nariz se atira. Por que você veio aqui, Ivan-tsarévitche?” - "Para saber se você pode me ajudar na minha desgraça.” - “E qual é a sua desgraça?” - O tsarévitche lhe contou. "Então, vá para casa, no seu quintal tem uma macieira, quebre três galhinhos verdes dela, os entrelace e bata com eles no cadeado que tranca o seu cachorrinho, nesse exato momento, ele se quebrará em pedacinhos. Então, vá sem medo atrás do dragão, ele não será páreo para você.”

Ivan-tsarévitche voltou para casa, libertou o cachorrinho que saiu correndo muito, muito bravo. Pegou ainda o lobinho e o ursinho e partiu ao encontro do dragão. Os bichos atacaram o dragão e o fizeram em pedacinhos. Ivan-tsarévitche pegou Mariatsarevna e passaram a viver tranqüilos e felizes e a prosperar.

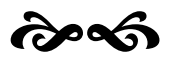

\footnotetext{
${ }^{3}$ No original khátka, diminutivo de kháta, espécie de isbá típica dos vilarejos ucranianos e do sul da Rússia.
} 


\section{O leite de animal selvagem ${ }^{1}(204)$}

Era uma vez um tsar que tinha um filho e uma filha. No reino vizinho, ocorreu uma grande desgraça: todo o povo morreu. Ivan-tsarévitche pediu então ao seu pai: "Pai! Dê-me a sua benção para eu ir viver naquele reino.” O pai não concordou. "Se é assim, eu irei por conta própria.” Ivan-tsarévitche foi-se, e sua irmã que não queria se separar dele foi também. Eles andaram por algum tempo até que encontraram na vasta planície uma isbazinha sobre pernas de galinha que girava, Ivan-tsarévitche disse: "Isbazinha, isbazinha! Fique como antes, como a sua mãe a colocou.” A isbazinha parou, eles entraram nela e lá estava deitada a Baba-Iagá: suas pernas estavam num canto, a cabeça no outro, os lábios no umbral e o nariz enfiado no teto. "Olá, Ivantsarévitche! E então, você está procurando uma tarefa ou fugindo de uma tarefa?” "Em alguns lugares eu procuro, em outros eu fujo; em certo reino, todo o povo morreu, eu estou indo viver lá.” Ela lhe disse: "Você pode ir para lá, mas é inútil levar a sua irmã, ela lhe causará muitos males.” Deu de beber e de comer para eles e os colocou para dormir.

No outro dia, o irmão e a irmã prepararam-se para seguir viagem; a Baba-Iagá deu ao Ivan-tsarévitche um cachorro e um novelinho azul: "Para onde o novelinho rolar, é para lá que você deve seguir.” O novelinho rolou até uma outra isbazinha sobre pernas de galinha. "Isbazinha, isbazinha! Fique como antes, como a sua mãe a colocou." A isbazinha parou, o tsarévitche e a tsarevna entraram nela e lá estava deitada a Baba-Iagá que perguntou: "E então, Ivan-tsarévitche, você está fugindo de uma tarefa ou procurando uma tarefa?” Ele lhe disse para onde e por que estava indo. "Você pode ir para lá, mas é inútil levar a sua irmã, ela lhe causará muitos males.” Deu de beber e de comer para eles e os colocou para dormir. Na manhã seguinte, deu para Ivan-tsarévitche um cachorro e uma toalha: "Se você encontrar no caminho um grande rio que não dê para atravessar, pegue esta toalha, segure-a por uma ponta e a sacuda, no mesmo instante surgirá uma ponte, depois que você passar para o outro lado, sacuda a toalha pela outra ponta e a ponte sumirá. Mas tenha cuidado, sacuda-a às escondidas, para que a sua irmã não veja.”

\footnotetext{
${ }^{1}$ Mesmo caso de títulos de contos anteriores. Esta é uma variante pertencente a um grupo formado por outras quatro. $\mathrm{O}$ título apresentado corresponde à primeira variante.
} 
Ivan-tsarévitche e a sua irmã seguiram em viagem; para onde o novelo rolava, era para lá que eles seguiam. Chegaram até um rio muito, muito largo. E a irmã falou: “Irmão! vamos sentar aqui para descansar.” Ela se sentou e não viu como o tsarévitche sacudiu a toalha e no mesmo instante surgiu uma ponte. "Vamos, irmãzinha! Deus nos deu uma ponte para atravessarmos para o outro lado.” Atravessaram o rio, e o tsarévitche sacudiu às escondidas a outra ponta da toalha, e a ponte sumiu como se nunca tivesse existido! Eles chegaram então àquele reino onde todo o povo havia morrido, não havia ninguém, tudo estava vazio! Começaram a viver lá por um tempo, e, um dia, o irmão decidiu ir caçar e foi com seus cachorros vaguear por entre florestas e pântanos.

Enquanto isto, chegou voando ao rio o Zmei Gorýnytch ${ }^{2}$, bateu contra a terra úmida e se transformou num jovem tão valente e belo que não dá para imaginar nem sonhar só no conto contar. E então chamou a tsarevna e falou: "De saudades de você, eu me consumi e me definhei, não consigo viver sem você!” A tsarevna apaixonou-se pelo Zmei Gorýnytch e gritou: "Voe até aqui, atravesse o rio!” - “Não consigo atravessar.” “E o que eu posso fazer?” - Seu irmão tem uma toalha, pegue-a dele, traga-a até o rio e a sacuda por uma ponta.” - “Ele não vai entregá-la para mim.” - “Mas então, o engane, diga que você quer lavá-la.” A tsarevna chegou ao palácio e nesse momento o irmão dela voltava da caça. O irmão trouxe muitas caças e as entregou a sua irmã para que ela as preparasse para o almoço do dia seguinte. Ela perguntou: "Irmão! Você não teria alguma roupa suja para lavar?” - “Vá, irmãzinha, ao meu quarto, lá você encontrará.” disse Ivan-tsarévitche, esquecendo completamente da toalha que a Baba-Iagá tinha lhe dado e da sua ordem para que ele não a mostrasse para a tsarevna. A tsarevna pegou a toalha e, no outro dia, o irmão foi caçar, e ela foi para o rio, sacudiu a toalha por uma ponta e nesse exato minuto surgiu uma ponte. O dragão atravessou a ponte. Eles começaram a se beijar, se acariciar e depois foram para o palácio. "Como poderíamos falou o dragão - acabar com seu irmão?” - “Imagine você, eu não sei.” - respondeu a tsarevna. "Então, é o seguinte: finja que você está doente e peça leite de loba, ele irá em busca do leite, quem sabe então ele não quebra o pescoço!

\footnotetext{
${ }^{2} \mathrm{O}$ termo zmei aceita duas traduções: dragão ou serpente; já o nome Gorýnytch age como um patronímico de gorá (montanha). Tal personagem, típico das bilinas e contos russos, geralmente é representado por um dragão de três, seis, nove ou doze cabeças. Pode se transformar em ser humano ou em objetos. Costuma ser responsável pelo rapto de uma ou mais tsarevnas, mantidas em cativeiro. Zmei Gorýnytch nem sempre se diferencia de outros dragões como Zmei Tugárin, Zmei Ógnennyi ou simplesmente zmei.
} 
O irmão voltou e encontrou a irmã deitada na cama, lamentando-se da sua doença: “Irmão! eu sonhei que eu poderia melhorar com leite de loba, será que você o conseguiria para mim? Pois sinto a minha morte se aproximando.” Ivan-tsarévitche foi para a floresta e viu uma loba alimentando os seus lobinhos, ele ia atirando nela, quando ela lhe falou com voz humana: "Ivan-tsarévitche, não atire, não me mate, não deixe os meus filhos órfãos, por que você não me diz do que precisa?” - "Eu preciso do seu leite.” - "Está bem, ordenhe, e ainda lhe darei um lobinho, ele vai lhe servir de forma fiel e verdadeira.” O tsarévitche tirou o leite, pegou o lobinho e foi para casa. O dragão o viu e disse para a tsarevna: "Seu irmão está vindo e traz um lobinho, diga a ele que agora você quer leite de ursa.” Disse isso e se transformou em uma vassourinha ${ }^{3}$. O tsarévitche entrou no quarto, seguido dos seus cachorros que entraram correndo, sentiram a presença de um espírito impuro ${ }^{4}$ e começaram a chacoalhar tanto a vassourinha que eram só pedaços que voavam!” - "O que é isso, irmão? - começou a gritar a tsarevna - acalme os seus animais, senão amanhã não terei com o que varrer!” Ivan-tsarévitche acalmou os seus animais e entregou à irmã o leite de loba.

Pela manhã, o irmão perguntou à irmã: “Como você está, irmãzinha?” - “Um pouquinho melhor, mas se você, meu irmão, trouxesse para mim o leite de ursa, eu me curaria completamente.” O tsarévitche foi para a floresta e viu uma ursa alimentando os seus filhos, mirou e quando ia atirando nela, ela começou a lhe implorar com voz humana: "Não atire em mim, Ivan-tsarévitche, não deixe os meus filhos órfãos, diga, do que você precisa?” - “Eu preciso do seu leite.” - “Está bem, e eu ainda lhe darei um ursinho.” O tsarévitche tirou o leite, pegou o ursinho e foi embora. O dragão o viu e falou para a tsarevna: "Seu irmão está vindo e traz um ursinho, peça-lhe ainda o leite de leoa!” Pronunciou isso e se transformou em uma vassoura, a tsarevna a enfiou debaixo da piétchka. De repente, os animais de Ivan-tsarévitche chegaram correndo, farejaram o espírito impuro, lançaram-se para debaixo da piétchka e começaram a sacudir a vassoura. "Acalme os seus animais, meu irmão, senão amanhã eu não terei com o que varrer a piétchka.” O tsarévitche gritou com seus cachorros, eles se deitaram debaixo da mesa, mas não pararam de rosnar.

\footnotetext{
${ }^{3}$ No original viénik, tanto pode ser o nome dado a um maço de ervas feito para se bater durante o banho a vapor quanto uma espécie de vassourinha utilizada na limpeza em geral.

${ }^{4}$ No original, netchístyi dukh. A expressão é conhecida também como netchístaia síla, isto é, força impura. Denominação aplicada a todas as criaturas sobrenaturais, pertencentes à assim chamada "mitologia baixa”, dentre as quais estão: russálka, liéchi, domovói, bánnik etc. Assim são chamados também em geral os maus espíritos, capetas, diabos etc.
} 
Na manhã seguinte, novamente o tsarévitche perguntou: “Como você está, irmãzinha?” - “Ah, nada me ajudou, irmão! Mas tive um sonho esta noite, sonhei que se você conseguisse leite de leoa, eu ficaria boa.” O tsarévitche foi para uma floresta muito, muito densa, andou por muito tempo e finalmente viu uma leoa alimentando os seus pequenos leõezinhos, quando ele ia atirando nela, ela falou com voz humana: "Não atire em mim, Ivan-tsarévitche, não deixe os meus filhinhos órfãos, por que você não me diz do que precisa?” - “Eu preciso do seu leite.” - “Está bem, e eu ainda lhe darei um leãozinho.” O tsarévitche tirou o leite, pegou o leãozinho e foi para casa. O Zmei Gorýnytch o viu e falou para a tsarevna: “Seu irmão está vindo e traz um leãozinho.” E começou a imaginar como o mataria.

Pensou, pensou e finalmente resolveu enviá-lo para o trigésimo estado, nesse reino havia um moinho protegido por doze portas de ferro, uma vez por ano elas se abriam por tão pouco tempo que, num piscar de olhos, já estavam fechadas. "Deixe que ele tente conseguir a farinha desse moinho!” Pronunciou essas palavras e se transformou em uma forquilha, a tsarevna a jogou debaixo da piétchka. Ivan-tsarévitche entrou no quarto, a cumprimentou e lhe deu o leite de leoa; novamente os cachorros farejaram o cheiro do dragão, lançaram-se para debaixo da piétchka e começaram a morder a forquilha. “Ah, irmão, acalme seus animais, senão eles irão quebrar alguma coisa!” O tsarévitche gritou com os cachorros, eles se deitaram debaixo da mesa, mas continuaram a olhar e a rosnar ferozmente para a forquilha.

De manhã, a tsarevna ficou mais doente do que antes, gemia e lamentava. "O que há com você, irmãzinha? - perguntou o irmão - o leite não a ajudou?” - “Não, em nada irmão!” - e começou a pedir que ele fosse ao moinho. Ivan-tsarévitche torrou alguns pedaços de pão para levar, pegou seus cachorros e animais e foi para o moinho. Ele esperou por muito tempo até o momento em que as doze portas de ferro se abriram, o tsarévitche então entrou, juntou às pressas a farinha e mal tinha conseguido sair as portas bruscamente se fecharam atrás dele, trancafiando os seus animais no moinho. Ivan-tsarévitche começou a chorar: "Pelo jeito, minha morte está próxima!”

Voltou para casa, o dragão viu que ele estava vindo sozinho, sem os animais. “Bom - falou - agora eu não tenho mais medo dele!” Lançou-se ao encontro do tsarévitche, escancarou sua goela e gritou: "Por muito tempo eu quis pegá-lo, tsarévitche. Já estava cansado de esperar, mas agora consegui e vou comê-lo!” - 
“Espere, antes de me comer é melhor me mandar para a bánia ${ }^{5}$ para eu me lavar.” O dragão concordou e ordenou ao próprio tsarévitche que ele trouxesse a água, cortasse a lenha e aquecesse a bánia. Ivan-tsarévitche começou a cortar a lenha e a trazer a água. Chegou então voando um corvo e grasnou: “Cra, cra, Ivan-tsarévitche! Corte a lenha, mas sem pressa, seus animais roeram quatro portas.” E então ele cortava a lenha e a jogava na água. O tempo ia passando, mas não havia o que fazer, era preciso aquecer a bánia. O corvo novamente grasnou: “Cra, cra, Ivan-tsarévitche! Aqueça a bánia, mas sem pressa, seus animais roeram oito portas.” Aqueceu então a bánia e começou a se lavar, mas só tinha um pensamento: “Tomara que meus animais consigam chegar a tempo!” Eis então que o cachorro chegou correndo e falou: “Em dupla, a morte já não assusta.” E atrás do cachorro vieram correndo todos os outros animais.

Zmei Gorýnytch por muito tempo ficou esperando Ivan-tsarévitche, até que não agüentou mais e foi até a bánia. Todos os animais lançaram-se sobre ele e o fizeram em pedacinhos. Ivan-tsarévitche juntou os pedacinhos, os queimou e espalhou as cinzas pela vasta planície. Voltou com os seus animais para o palácio e queria cortar a cabeça da sua irmã, mas ela caiu de joelhos diante dele e começou a chorar e a suplicar. O tsarévitche não a matou, mas a levou para a estrada e a amarrou num poste de pedra, ao lado, ele colocou uma braçada de feno e duas tinas: uma com água e a outra vazia e falou: "Se você beber toda a água, comer todo o feno e chorar até encher a tina de lágrimas, então Deus lhe perdoará e eu também lhe perdoarei.”

Ivan-tsarévitche deixou a irmã no poste de pedra e foi para além das trinta terras; andou, andou e chegou a uma grande e majestosa cidade; viu que metade do povo se divertia e cantava e que a outra metade derramava amargas lágrimas. Pediu para pernoitar na casa de uma velhinha e lhe perguntou: "Diga-me, vovó, por que metade do povo se diverte e canta enquanto a outra metade está em prantos?” A velha respondeu: “Ah, meu caro! Um dragão de doze cabeças veio morar no nosso lago e toda noite ele vem comer uma pessoa, por isso nós criamos uma ordem, dizendo que lado e que dia ficará à mercê do dragão. Por isso, aqueles que a vez já passou estão se divertindo, enquanto os outros derramam rios de lágrimas. - “E agora, é a vez de quem?” - “Agora é a vez da filha do tsar, ela é a sua única filha, mas ele será obrigado a entregá-la. O tsar anunciou que se ele encontrasse alguém que matasse esse dragão, ele daria metade do

\footnotetext{
${ }^{5}$ Ver Glossário, p. 158.
} 
seu reino e a sua filha em casamento, mas onde hoje em dia se encontra tal bogatýr? Por causa dos nossos pecados, todos eles desapareceram!”

Ivan-tsarévitche no mesmo instante reuniu seus animais e foi para o lago, e lá já estava a bela tsarevna chorando amargamente. "Não tenha medo, tsarevna, eu vou defendê-la!” De repente, o lago começou a se agitar, a se levantar e surgiu o dragão de doze cabeças. “Ah, Ivan-tsarévitche, bogatýr russo, para que você veio até aqui?” Você veio para a luta ou para a paz?” - “Por que eu viria para a paz? Um bogatýr russo não vem para isso.” - respondeu o tsarévitche e lançou todos os seus animais sobre o dragão: dois cachorros, o lobo, o urso e o leão. Os animais num instante o fizeram em pedacinhos. Ivan-tsarévitche cortou as línguas de todas as doze cabeças do dragão, colocou-as no bolso, soltou os seus animais para passearem, deitou no colo da tsarevna e começou a dormir profundamente. De manhã cedo, chegou um aguadeiro com seu barril, viu o dragão morto, a tsarevna viva e no colo dela o jovem valente dormindo. $\mathrm{O}$ aguadeiro se aproximou deles, puxou a espada, cortou a cabeça de Ivan-tsarévitche e obrigou a tsarevna a jurar que ela o reconheceria como o seu salvador. Depois ele juntou as cabeças do dragão e as levou para o tsar, mas ele não sabia que as cabeças estavam sem as línguas.

Nem muito nem pouco, o tempo passou, até que os animais de Ivan-tsarévitche chegaram correndo e o viram deitado sem cabeça. O leão o cobriu com capim e se sentou ao seu lado. Os corvos com seus corvinhos atacaram o cadáver com bicadas, o leão esperou um momento oportuno, capturou um corvinho e quis rasgá-lo em dois. O velho corvo gritou: "Não mate meu filhote, ele não lhe fez nada! Pode me pedir o que você quiser, eu farei qualquer coisa.” - "Eu preciso da água da morte e da água da vida - respondeu o leão - traga-as para mim e então eu soltarei o seu corvinho.” O corvo voou e antes do sol se pôr ele já tinha voltado e trazido dois frasquinhos com a água da morte e da vida. O leão dilacerou o corvinho e borrifou a água da morte, os pedaços se uniram, borrifou a água da vida e o corvinho voltou à vida e voou atrás do velho corvo. Então, o leão borrifou a água da morte e da vida em Ivan-tsarévitche, que se levantou e falou: "Nossa, quanto tempo eu dormi!” - "Você dormiria por séculos, se não fosse eu!” - respondeu-lhe o leão que lhe contou como o encontrou morto e como lhe devolveu a vida.

O tsarévitche chegou à cidade, onde todos estavam se divertindo; abraçavam-se, beijavam-se e cantavam. Ele perguntou à velha: “Diga-me, vovó, por que tanta alegria?” - "Veja só o que aconteceu: o aguadeiro combateu o dragão e salvou a tsarevna, e o tsar 
lhe entregou a sua filha em casamento.” - "Será que eu poderia ver esse casamento?”"Se você souber tocar alguma coisa, pode ir, lá agora aceitam todos os músicos.” - "Eu sei tocar gúsli.” - "Então, vá! A tsarevna adora que toquem gúsli para ela.”

Ivan-tsarévitche comprou uma gúsli e foi para o palácio. Começou a tocar e todos escutavam e se maravilhavam, de onde surgiu um músico tão bom. A tsarevna encheu um cálice de vinho e lhe serviu com as suas próprias mãos, ao olhá-lo lembrou-se do seu salvador, e as lágrimas começaram a escorrer dos seus olhos. "Por que está chorando?” - perguntou o tsar. Ela falou: “Lembrei-me do meu salvador.” Ivantsarévitche anunciou-se então para o tsar, contou tudo o que tinha acontecido e como prova tirou do bolso as línguas do dragão. Agarraram o aguadeiro pelos braços, o levaram e o fuzilaram, e Ivan-tsarévitche se casou com a bela tsarevna. E de tanta alegria se lembrou da sua irmã, foi até o poste de pedra e viu que ela já tinha comido o feno, bebido a água e enchido a tina com as suas lágrimas. Ivan-tsarévitche a perdoou e a levou consigo, e todos passaram a viver tranqüilos e felizes e a prosperar e do mal se afastar.

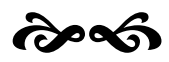




\section{A pena de Finíst, o falcão brilhante ${ }^{1}$ (235)}

Era uma vez um velho e uma velha. Eles tinham três filhas, a menor era tão bela que não dá para no conto contar nem com a pena anotar. Um dia, o velho aprontou-se para ir até a cidade em uma feira ${ }^{2}$ e falou: "Minhas filhas queridas! O que vocês querem, mandem, comprarei tudo na feira.” A mais velha pediu: “Compre-me, pai, um vestido novo.” A do meio: “Compre-me, pai, um xale.” E a menor falou: “Compre-me, pai, uma florzinha escarlate.” O velho começou a rir da sua filhinha caçula: "Mas para que você quer uma florzinha escarlate, sua tolinha? Que proveito você terá com isso? Eu posso comprar para você as melhores roupas que existem.” Mas por mais que ele falasse, ele não conseguia convencê-la de jeito nenhum. E ela dizia: "Compre-me uma florzinha escarlate e apenas isso.”

O velho foi para a feira, comprou para a filha mais velha um vestido, para a do meio um xale, mas a florzinha escarlate ele não achou em nenhum lugar da cidade. Já estava de partida, quando encontrou um velhinho desconhecido que trazia nas mãos uma florzinha escarlate. "Venda-me, velhinho, sua florzinha!” - "Ela não esta à venda, pois ela guarda um segredo, mas se a sua filha mais nova se casar com o meu filho Finíst, o falcão brilhante, eu lhe darei a florzinha de graça.” O pai pensou: "Se eu não pegar a florzinha minha filhinha ficará magoada, mas se eu pegá-la, terei de entregá-la para se casar sabe Deus com quem.” Então, pensou, pensou e no final pegou a florzinha escarlate. “Qual é o problema? - pensou - Depois quando ele vier pedi-la em casamento, se ele não for bom, podemos recusar!”

Chegou em casa, deu para a filha mais velha o vestido, para a do meio o xale e para a menor deu a florzinha e falou: "Essa sua florzinha não me agrada, minha filha querida, não me agrada mesmo!” E sussurra baixinho no ouvido dela: “Na verdade, essa florzinha guarda um segredo e não estava à venda, eu a peguei de um velho desconhecido sob uma condição, de lhe dar como esposa ao filho dele, Finíst, o falcão brilhante.” -“Não fique triste, pai - respondeu a filha - pois ele é muito bom e carinhoso; como um falcão brilhante voa no alto do céu e ao bater contra a terra úmida se transforma em um jovem valente!” - “Mas então você o conhece?” - “Conheço sim, pai! No último domingo ele estava na missa e não parava de olhar para mim, eu até falei

\footnotetext{
${ }^{1}$ Mesmo caso de títulos de contos anteriores. Esta é uma variante pertencente a um grupo formado por outras duas. O título apresentado corresponde à primeira variante.

${ }^{2}$ No original iámarka. Grande feira que reunia pessoas de diferentes classes sociais. Além da prática comercial, era freqüente também a apresentação de artistas populares.
} 
com ele... e ele me ama, pai!” O velho balançou a cabeça e olhou para a filha profundamente, fez sobre ela o sinal da cruz e falou: "Vá para o seu quarto ${ }^{3}$, minha filha querida! Já é hora de dormir, a manhã é mais sábia do que a noite - depois resolveremos!” E então a filha se trancou no quarto, colocou a florzinha escarlate na água, abriu a janelinha e olhou para o horizonte azul.

Não se sabe de onde, lançou-se diante dela Finíst, o falcão brilhante, de penas coloridas. Ele entrou voando pela janelinha, bateu contra o chão e se transformou em um jovem valente. A moça ficou assustada, mas depois quando ele começou a conversar com ela, não se sabe como, mas o seu coração foi tomado de alegria e bondade. Conversaram até o amanhecer, sobre o quê, eu não sei, só sei que assim que começou a clarear, Finíst, o falcão brilhante, de penas coloridas, a beijou e disse: “Toda noite, minha querida, assim que você colocar a florzinha escarlate na janela, eu chegarei voando! Eis aqui para você uma pena da minha asa, se você precisar de algum traje, saia até a soleira e apenas balance a pena para a direita - num instante, diante de você, surgirá tudo o que a sua alma desejar!” Ele a beijou mais uma vez, transformou-se em falcão brilhante e voou para além da floresta escura. A moça seguiu com o olhar o seu prometido indo embora, depois fechou a janela e foi dormir. Desde então, toda noite, assim que ela colocava a florzinha escarlate sobre a janela aberta, chegava o jovem valente, Finíst, o falcão brilhante.

Eis então que chegou o domingo. As irmãs mais velhas começaram a se vestir para ir à missa. "E você, o que irá vestir? Você não tem nenhuma roupa nova!” falaram para a irmã caçula. Ela respondeu: "Não tem problema, eu rezarei em casa mesmo!” As irmãs mais velhas foram para a missa, e a caçula ficou toda suja na janela olhando para os fiéis que iam para a santa igreja. Esperou passar um tempo e foi até a soleira, balançou a pena colorida para a direita e não se sabe de onde, surgiu diante dela uma carruagem de cristal com cavalos de raça, criados trajados com roupas douradas e vestidos e adornos com valiosas pedras preciosas.

Em um minuto, a bela donzela se vestiu, sentou-se na carruagem e saiu em disparada para a igreja. Todo o povo ficou olhando a beldade e a admirando. "Pelo visto, ela é alguma tsarevna!" - falavam as pessoas entre si. Assim que começaram a cantar o Digno ${ }^{4}$, ela imediatamente saiu da igreja, sentou na carruagem e foi embora. Os

\footnotetext{
${ }^{3}$ No original svetiólka, um pequeno quarto, localizado na parte superior da casa.

${ }^{4}$ No original Dostóino. Referência ao Dostóino est', um dos mais populares cânticos litúrgicos, em homenagem à Nossa Senhora, cantado no fim da missa.
} 
fiéis saíram para ver aonde ela estava indo, mas não havia mais nada!” As pegadas já tinham sumido há muito tempo. E assim que a nossa beldade chegou à porta da sua casa, imediatamente balançou a pena colorida para a esquerda: num instante os criados a despiram e a carruagem desapareceu de diante dos olhos. Ela então ficou como antes, como se nada tivesse acontecido, estava novamente na janelinha vendo os fiéis saindo da igreja e voltando para as suas casas. As suas irmãs também chegaram em casa. “Nossa, irmãzinha, hoje havia uma beldade na missa! Era um verdadeiro primor. Era tão bela que não dá para no conto contar nem com a pena anotar! Deveria ser uma tsarevna de outras terras, era tão suntuosa, estava tão bem vestida!”

Passaram um segundo e um terceiro domingo, e a bela donzela continuava a enganar os fiéis, suas irmãs, seu pai e sua mãe. Mas, na última vez, enquanto se despia, esqueceu de tirar da trança um alfinete de cabelo de diamantes. As irmãs mais velhas voltaram da igreja e lhe contaram sobre a bela tsarevna, mas quando olharam para a sua irmã caçula viram um diamante brilhando na sua trança. “Ah, irmãzinha! O que é isso que você tem aí? - começaram a gritar as moças. Um alfinete de cabelo exatamente igual a esse estava hoje na cabeça da tsarevna. Onde você o conseguiu?” A bela donzela soltou um grito de surpresa e foi correndo para o seu quarto. As indagações, suposições e cochichos não tinham fim, mas a caçula se calou e ria às escondidas.

Então as irmãs mais velhas começaram a vigiá-la e toda noite elas iam escutar o que se falava no quarto da caçula. Uma vez ouviram uma conversa dela com Finíst, o falcão brilhante e, ao amanhecer, viram com seus próprios olhos ele saindo pela janela e voando para além da floresta escura. Pelo visto, as irmãs mais velhas eram maldosas: combinaram de às escondidas colocarem durante a noite facas na janela do quarto da irmã, para que Finíst, o falcão brilhante, cortasse as suas asas coloridas. Dito e feito, a irmã caçula nem suspeitava e colocou sua florzinha escarlate na janela, deitou-se na cama e dormiu profundamente. Finíst, o falcão brilhante, chegou voando e assim que passou pela janelinha cortou a sua pata esquerda, mas a bela donzela não sabia de nada e continuou dormindo doce e calmamente. Enfurecido, o falcão brilhante lançou-se para o alto do céu e partiu para além da floresta escura.

De manhã, a bela acordou e olhou para todos os lados: já havia clareado e do jovem valente não havia nem sinal! Olhou para a janela e viu que nela tinham sido colocadas afiadas facas em forma de cruz e que delas gotejava um sangue escarlate sobre a florzinha. Por muito tempo a donzela derramou amargas lágrimas e muitas noites passou sem dormir na janela do seu quarto, tentava balançar a pena colorida, mas 
era tudo em vão! Nem Finíst, o falcão brilhante, vinha e nem enviava os seus criados! Por fim, com lágrimas nos olhos, ela foi até o seu pai pedir a sua benção. "Vou - disse para onde os olhos alcançam!” Ordenou que lhe forjassem três pares de sapatos de ferro, três cajados de ferro, três gorros de ferro e três hóstias de ferro. Um par de sapatos colocou nos pés, um gorro na cabeça e um cajado na mão e foi em direção de onde vinha Finíst, o falcão brilhante.

Caminhou pela densa floresta, passando por cepos e tocos, e os seus sapatos de ferro se gastaram, o seu gorro de ferro se esfarrapou, o seu cajado se quebrou, a hóstia foi comida, mas a bela donzela continuava caminhando e caminhando, e a floresta ficava cada vez mais escura, cada vez mais densa. De repente, viu diante de si uma isbazinha de ferro fundido sobre pernas de galinha que girava sem parar. A donzela falou: "Isbazinha, isbazinha! Fique de costas para a floresta e de frente para mim.” A isbazinha girou e ficou de frente para ela. Ela entrou na isbazinha e nela estava deitada a Baba-Iagá: de um canto ao outro, os lábios na viga e o nariz no teto. “Fu, fu, fu! Antes nunca tinha se visto nem se sentido o cheiro de um russo por aqui e eis que agora surge um andando livremente pelo mundo e no meu nariz se atira. Para onde você se dirige, bela donzela? Você está fugindo de uma tarefa ou procurando uma tarefa?” - “Eu tinha, vovó, Finíst, o falcão brilhante, de asas coloridas, mas as minhas irmãs lhe fizeram um grande mal. E agora o estou procurando." "Você terá de ir bem longe, meu bebê! É preciso ainda ir além das trinta terras. Finíst, o falcão brilhante, de penas coloridas, mora no qüinquagésimo reino, no octogésimo estado e já está noivo de uma tsarevna.”

A Baba-Iagá deu o que tinha de comer e de beber para a donzela e a colocou para dormir. Na manhã seguinte, logo que começou a clarear, ela a acordou e lhe deu um precioso presente: um martelinho de ouro e dez pregos de diamantes e ordenou: “Quando você chegar ao mar azul, a noiva de Finíst, o falcão brilhante, irá até a margem passear, você então pegue o martelinho de ouro e comece a bater nos pregos de diamante, ela tentará comprá-los de você, bela donzela, não aceite nada, apenas peça para ver Finíst, o falcão brilhante. E agora, vá com Deus até a casa da minha irmã do meio!”

Novamente a bela donzela caminhava pela floresta escura e quanto mais caminhava mais a floresta ficava escura e densa, as árvores eram tão altas que chegavam até o céu. E o segundo par de sapatos se gastou, o segundo gorro se esfarrapou, o segundo cajado de ferro se quebrou, a segunda hóstia de ferro foi comida, e então diante da bela donzela apareceu uma isbazinha de ferro fundido sobre pernas de 
galinha que girava sem parar. "Isbazinha, isbazinha! Fique de costas para a floresta e de frente para mim, quero entrar e o pão comer.” A isbazinha girou as costas para a floresta e a frente para a donzela. Ela entrou e na isbazinha estava deitada a Baba-Iagá: de um canto ao outro, os lábios na viga e o nariz no teto. " $\mathrm{Fu}$, fu, fu! Antes nunca tinha se visto nem se sentido o cheiro de um russo por aqui e eis que agora surge um andando livremente pelo mundo! Para onde você se dirige, bela donzela?” - "Vovó, estou procurando Finíst, o falcão brilhante.” “Ah, ele está prestes a se casar. Hoje é o último dia de solteiro dele.” - disse a Baba-Iagá, que deu de comer e de beber à donzela e a pôs para dormir. Na manhã seguinte, ao despontar do dia, a acordou e lhe deu um pires de ouro e uma bolinha de diamante e ordenou muito severamente: “Quando você chegar à margem do mar azul, comece a rolar a bolinha de diamante sobre o pires de ouro, a noiva de Finíst, o falcão brilhante, virá até você para comprar o pires com a bolinha; mas não aceite nada, apenas peça para ver Finíst, o falcão brilhante, de penas coloridas. Agora, vá com Deus até a casa da minha irmã mais velha!”

Novamente, a bela donzela caminhava pela floresta escura e quanto mais ela caminhava mais a floresta ficava escura e densa. E o terceiro par de sapatos se gastou, o terceiro gorro se esfarrapou, o último cajado se quebrou e a última hóstia foi comida. Encontrou uma isbazinha de ferro fundido sobre pernas de galinha que volta e meia girava. "Isbazinha, isbazinha! Vire de costas para a floresta e de frente para mim, quero entrar e o pão comer.” A isbazinha virou. Na isbazinha novamente estava deitada a Baba-Iagá: de um canto ao outro, os lábios na viga e o nariz no teto. "Fu, fu, fu! Antes nunca tinha se visto nem se sentido o cheiro de um russo por aqui e eis que agora surge um andando livremente pelo mundo. Para onde você se dirige, bela donzela?” - "Vovó, estou procurando Finíst, o falcão brilhante.” “Ah, bela donzela, ele já se casou com a tsarevna! Tome, pegue o meu veloz cavalo, monte nele e vá com Deus!” A donzela montou no cavalo e seguiu em frente, e a floresta ficava cada vez menos e menos densa.

Eis então que à sua frente se estendia um largo e vasto mar azul e lá ao longe brilhavam como fogo as cúpulas de ouro dos altos tiérens ${ }^{5}$ de pedra branca. "Parece que este é o reino de Finíst, o falcão brilhante!” - pensou a donzela que se sentou sobre a areia fina e começou a bater com o martelinho de ouro nos pregos de diamante. De repente, surgiu andando pela margem a tsarevna com suas amas, aias e fiéis criados, parou e começou então a negociar os pregos de diamante e o martelinho de ouro.

\footnotetext{
${ }^{5}$ Ver nota 4, do conto 4, p. 109.
} 
“Deixe-me, tsarevna, apenas ver Finíst, o falcão brilhante, e eu os darei de graça.” respondeu a moça. "Mas Finíst, o falcão brilhante, está dormindo agora e ordenou que ninguém o incomodasse; mas se você me der os seus pregos e seu martelinho lindos eu então posso mostrá-lo para você.”

Ela então pegou o martelinho e os pregos, foi correndo para o palácio e espetou na roupa de Finíst, o falcão brilhante, um alfinete mágico para que ele dormisse mais profundamente e por mais tempo, não conseguindo se levantar; depois ordenou às suas amas para que elas acompanhassem a bela donzela ao palácio até o seu marido, o falcão brilhante, enquanto ela própria foi passear. Por muito tempo, a donzela se consumiu, por muito tempo, chorou sobre o seu amado, mas não conseguia acordá-lo... Depois de passear à vontade, a tsarevna voltou para casa, enxotou a donzela e retirou o alfinete. Finíst, o falcão brilhante, despertou, "Nossa, quanto tempo eu dormi! Aqui esteve alguém - disse - que muito chorou e se lamentou sobre mim, mas eu não conseguia abrir os olhos de jeito nenhum de tão cansado que eu estava!” "Você apenas sonhou respondeu a tsarevna - não havia ninguém aqui."

No outro dia, a bela donzela novamente se sentou na margem do mar azul e rolou a bolinha de diamante sobre o pires de ouro. A tsarevna saiu para passear, a viu e pediu: "Venda-me isso!" - "Permita-me apenas ver Finíst, o falcão brilhante, e eu os darei de graça!” A tsarevna concordou e novamente espetou um alfinete na roupa de Finíst, o falcão brilhante. Novamente, a bela donzela chorou amargamente sobre o seu amado, mas não conseguiu acordá-lo. No terceiro dia, ela estava sentada na margem do mar azul muito triste e amargurada, alimentado o seu cavalo com brasas ardentes. A tsarevna viu que o cavalo comia fogo e começou a negociá-lo. "Permita-me apenas ver Finíst, o falcão brilhante, e eu o darei de graça!” A tsarevna concordou, foi correndo até o palácio e disse: "Finíst, falcão brilhante! Deixa eu lhe acariciar a cabeça.” E enquanto lhe afagava a cabeça, prendeu nos seus cabelos um alfinete, no mesmo momento, ele adormeceu profundamente e então ela enviou as suas amas atrás da bela donzela.

Assim que ela chegou, tentou acordar o seu amado, o abraçou, o beijou e chorou muito, muito amargamente, mas nada o acordava! Então, ela começou a acariciar a sua cabeça e por acaso derrubou o alfinete mágico. Finíst, o falcão brilhante, de penas coloridas, no mesmo momento despertou, viu a bela donzela e se alegrou muito! Ela lhe contou tudo o que havia acontecido: como as suas malvadas irmãs a invejaram, como ela vagueou pelo mundo e como negociou com a tsarevna. Ele se apaixonou por ela ainda mais do que antes, a beijou na sua doce boca e ordenou que, sem demora, se 
convocassem os boiardos, príncipes $^{6}$ e todas as pessoas importantes e então lhes perguntou: “Como vocês julgam, com qual mulher devo viver: com aquela me vendeu ou com a que me resgatou?” Todos os boiardos, príncipes e pessoas importantes lhe responderam em uma só voz: "Fique com aquela que o resgatou e a aquela o vendeu, pendure-a nos portões e a fuzile. E assim fez Finíst, o falcão brilhante, de penas coloridas!

\section{कon}

\footnotetext{
${ }^{6}$ No original kniás, chefe do exército e governante dos principados da Rússia antiga.
} 


\section{A tsarevna-rã ${ }^{1}$ (269)}

Em certo reino, em certo estado, viviam um tsar e uma tsarina que tinham três filhos: todos tão jovens, solteiros e valentes que não dá para no conto contar nem com a pena anotar; o mais novo se chamava Ivan-tsarévitche. Um dia, o tsar lhes falou as seguintes palavras: "Meus filhos queridos, peguem cada um uma flecha, estiquem seus arcos tesos e atirem para diferentes lados; no lugar em que as flechas caírem, lá vocês devem procurar suas noivas.” O irmão mais velho lançou sua flecha, e ela caiu no pátio de um boiardo, diretamente na frente do tiérem de uma donzela; o irmão do meio lançou, e a flecha caiu no pátio de um mercador e parou na porta da entrada principal, nessa entrada estava uma amável donzela, a filha do mercador; o irmão mais novo lançou, e a flecha caiu em um pântano imundo e foi pega pela rã coaxante. Ivantsarévitche então falou: "Como posso me casar com essa coaxante? Ela não é igual a mim!” - “Case-se! - respondeu-lhe o pai - Parece que este é o seu destino.”

Os tsarévitches então se casaram: o mais velho com a filha do boiardo, o do meio com a filha do mercador e Ivan-tsarévitche com a rã coaxante. O tsar os chamou e ordenou: “Quero que suas mulheres me preparem para amanhã um pão macio e branco.” Ivan-tsarévitche voltou para os seus aposentos triste, com a sua impetuosa cabeça caída entre os ombros. "Cro, cro, Ivan-tsarévitche! Por que você está tão desolado? perguntou-lhe a rã - será que você ouviu de seu pai alguma palavra desagradável?” “Como eu não ficaria desolado? O senhor meu pai ordenou que você lhe prepare para amanhã um pão macio e branco.” - “Não se aflija, tsarévitche! Deite-se, durma e descanse, a manhã é mais sábia que a noite!” Ela colocou o tsarévitche para dormir, tirou a pele de rã e se transformou numa amável donzela, Vassilíssa, a sábia, saiu até a porta da entrada principal e gritou em voz alta: “Amas e aias! Reúnam-se, aprontem-se, preparem um pão macio e branco como aquele que eu comia na casa de meu pai.”

Na manhã seguinte, Ivan-tsarévitche acordou, e a coaxante já tinha há muito tempo preparado o pão, e ele era tão bom que não dá para imaginar nem sonhar, só no conto contar! O pão estava decorado com muita engenhosidade, nas suas bordas havia cidades reais com suas barreiras. O tsar agradeceu Ivan-tsarévitche pelo pão e, no mesmo instante, deu outra ordem aos seus três filhos: “Quero que suas mulheres teçam para mim em uma única noite um tapete.” Ivan-tsarévitche voltou triste, com a sua

\footnotetext{
${ }^{1}$ Mesmo caso de títulos de contos anteriores. Esta é uma variante pertencente a um grupo formado por outras três. $\mathrm{O}$ título apresentado corresponde à primeira variante.
} 
impetuosa cabeça caída entre os ombros. “Cro, cro, Ivan-tsarévitche! Por que você está tão desolado? Será que você ouviu de seu pai alguma palavra dura, desagradável?” “Como eu não ficaria desolado? O senhor meu pai ordenou que você teça para ele em uma única noite um tapete de seda.” - "Não se aflija, tsarévitche! Deite-se, durma e descanse, a manhã é mais sábia que a noite!” Ela o colocou para dormir, tirou a pele de rã e se transformou numa amável donzela, Vassilíssa, a sábia, saiu até a porta da entrada principal e gritou em voz alta: “Amas e aias! Reúnam-se, aprontem-se, teçam um tapete de seda e que ele seja como aquele em que eu me sentava na casa de meu pai!”

Dito e feito. Na manhã seguinte, Ivan-tsarévitche acordou, e a coaxante já tinha há muito tempo preparado o tapete, e ele era tão lindo que não dá para imaginar nem sonhar, só no conto contar! O tapete estava decorado com ouro e prata e engenhosos bordados. O tsar agradeceu Ivan-tsarévitche pelo tapete e no mesmo instante deu uma ordem, queria agora que todos os três tsarévitches apresentassem-se diante dele com suas mulheres. Novamente Ivan-tsarévitche voltou triste, com a sua impetuosa cabeça caída entre os ombros. “Cro, cro, Ivan-tsarévitche! Por que você está desolado? Será que você ouviu de seu pai alguma palavra desagradável?” - “Como eu não ficaria desolado? O senhor meu pai ordenou que eu e você nos apresentemos diante dele: como vou mostrar você para as pessoas?” - “Não se aflija, tsarévitche! Vá sozinho até o tsar, e eu irei em seguida, assim que você ouvir o estrondo de um trovão, diga: “'É a minha rãzinha vindo na sua caixinha.”

Eis então que os irmãos mais velhos apresentaram-se com suas mulheres enfeitadas e arrumadas e começaram a rir de Ivan-tsarévitche: "E você, irmão, por que não trouxe sua mulher? Você poderia trazê-la em um lencinho! Onde foi mesmo que você encontrou essa beldade? Pelo visto, você percorreu todos os pântanos, não?” De repente, fortes estrondos de trovão começaram a ressoar, todo o palácio começou a tremer, os convidados ficaram muito assustados, pularam de seus lugares e não sabiam o que fazer; e Ivan-tsarévitche falou: "Não tenham medo, senhores! É a minha rãzinha que chegou na sua caixinha.” Então chegou voando à entrada do palácio uma carruagem dourada com seis cavalos e de dentro dela saiu Vassilíssa, a sábia - tão linda que não dá para imaginar nem sonhar, só no conto contar! Ela pegou Ivan-tsarévitche pelas mãos e o levou às mesas de carvalhos, cobertas com toalhas bordadas.

Os convidados começaram a comer, a beber e a se divertir; Vassilíssa, a sábia, deu um gole no copo e o que sobrou derramou dentro da sua manga esquerda, provou um cisne, e os ossinhos ela escondeu dentro da sua manga direita. As mulheres dos 
tsarévitches mais velhos perceberam a sua artimanha e começaram a fazer o mesmo. Depois, Vassilíssa, a sábia, foi dançar com Ivan-tsarévitche, balançou a sua mão esquerda e se fez um lago, balançou a sua mão direita e cisnes brancos começaram a nadar na água, o tsar e os convidados ficaram maravilhados. Então, as mulheres dos filhos mais velhos começaram a dançar, balançaram a mão esquerda: e os convidados ficaram cheios de respingos, balançaram a mão direita: e os ossos caíram diretamente nos olhos do tsar! O tsar irritou-se e as enxotou grosseiramente.

Enquanto isso, Ivan-tsarévitche aproveitou e foi correndo para casa, encontrou a pele de rã e a queimou em fogo alto. Vassilíssa, a sábia, chegou e percebeu que a sua pele de rã não estava em nenhum lugar, então se desanimou e se entristeceu e falou para o tsarévitche: “Ah, Ivan-tsarévitche! O que você fez? Se você esperasse mais um pouquinho, eu seria sua para sempre, mas agora adeus! Procure-me além das trinta terras, no trigésimo estado, no reino de Koschiéi, imortal.” Ela se transformou em um cisne branco e voou pela janela.

Ivan-tsarévitche começou a chorar amargamente, rezou a Deus e partiu em direção aos quatro cantos da terra, para onde os olhos alcançavam. Ele andou nem para perto nem para longe, por um tempo nem longo nem curto até que encontrou um velho muito velhinho: “Olá, jovem valente! O que você está procurando? Para onde você se dirige?” O tsarévitche lhe contou as suas desgraças. “Eh, Ivan-tsarévitche! Por que você queimou a pele de rã? Não foi você que a colocou, não era você que tinha de tirá-la! Vassilíssa, a sábia, nasceu muito mais astuta e sábia do que o pai dela, por isso ele ficou bravo com ela e ordenou que por três anos ela seria uma coaxante. Pegue este novelo e, para onde ele rolar, siga sem vacilar.”

Ivan-tsarévitche agradeceu o velho e começou a seguir o novelinho. Caminhando pela vasta planície, encontrou um urso e disse: “Eh, vou matar essa fera!” Mas o urso lhe falou: "Não me mate, Ivan-tsarévitche! Um dia eu lhe serei útil.” Continuou caminhando e viu sobre ele um pato voando, o tsarévitche apontou a sua espingarda e quando ia atirando no pássaro, de repente, ele profetizou com voz humana: "Não me mate, Ivan-tsarévitche! Eu lhe serei útil.” Ele ficou com pena e seguiu em frente. Viu então correndo uma lebre serelepe, novamente o tsarévitche pegou a sua espingarda e a apontou, mas a lebre lhe falou com voz humana: "Não me mate, Ivan-tsarévitche! Eu lhe serei útil.” O tsarévitche ficou com pena e seguiu em frente em direção ao mar azul, viu sobre a areia um lúcio morrendo. “Ah, Ivan-tsarévitche - falou o lúcio - tenha piedade de mim, solte-me no mar.” Ele o jogou no mar e seguiu pela margem. 
Nem longo nem curto, o tempo passou, e o novelinho rolou até uma isbazinha, a isbazinha estava sobre pernas de galinha e girava em torno de si mesma. Ivantsarévitche falou: "Isbazinha, isbazinha! Fique como antes, como a sua mãe a colocou, de frente para mim e de costas para o mar.” A isbazinha virou as costas para o mar e a frente para ele. O tsarévitche entrou nela e viu: deitada, sobre a piétch, sobre a nona fileira de tijolos, a Baba-Iagá, pernas de osso; no teto, o nariz encravado, na soleira, o ranho pendurado, nos ganchos, as tetas enroladas, e os dentes ela mesma afiava. "Olá2, jovem valente! Por que veio visitar-me?” - perguntou a Baba-Iagá a Ivan-tsarévitche. “Ah, sua velha, rabugenta! Antes de tudo a mim, jovem valente, você deveria dar de comer e de beber e um banho ${ }^{3}$, e só depois então fazer perguntas.”

A Baba-Iagá deu-lhe de comer e beber e um banho; e então o tsarévitche lhe contou que ele procurava a sua mulher Vassilíssa, a sábia. “Ah, conheço! - disse a Baba-Iagá - Ela agora está com o Koschiéi, imortal, vai ser difícil pegá-la, não é fácil vencer o Koschiéi: a morte dele está na ponta de uma agulha, a agulha num ovo, o ovo numa pata, a pata numa lebre, a lebre num baú e o baú está em cima de um alto carvalho que é cuidado pelo Koschiéi como se fosse seus próprios olhos.”

A Iagá indicou em que lugar estava esse carvalho, Ivan-tsarévitche foi para lá mas não sabia como fazer para alcançar o baú. De repente, não se sabe de onde veio correndo um urso que arrancou a árvore com raiz e tudo, o baú caiu e se quebrou em mil pedaços, do baú saiu a toda velocidade uma lebre que se lançou em disparada, de repente surgiu atrás dela uma outra lebre que a alcançou, a agarrou e a fez em pedacinhos. Da lebre, saiu voando uma pata que se lançou para muito, muito alto, e atrás dela um pato se atirou e a atacou: no mesmo instante a pata deixou cair um ovo e o ovo caiu no mar. Ivan-tsarévitche vendo tal desgraça inevitável, começou a chorar, de repente se aproximou da margem um lúcio carregando o ovo entre os dentes. Ivantsarévitche pegou o ovo, o partiu, apanhou a agulha e quebrou a sua ponta: muito se debateu o Koschiéi, muito se jogou para todos os lados, mas a sua morte havia chegado! Ivan-tsarévitche foi até a morada do Koschiéi, pegou a Vassilíssa, a sábia, e voltou para a sua casa. Depois disso, eles viveram juntos e felizes para sempre.

\section{0a}

\footnotetext{
${ }^{2}$ No original goi essi, uma expressão folclórica com sentido de exclamação ou saudação.

${ }^{3}$ Vale lembrar que o banho russo ocorre na bánia, englobando várias etapas.
} 


\section{Vassilíssa, a bela (104)}

Em certo reino vivia um mercador. Por doze anos, ele foi casado e teve somente uma filha: Vassilíssa, a bela. Quando a mãe de Vassilíssa morreu, a garota tinha oito anos. No momento da sua morte, a mulher do mercador chamou a filha, tirou de debaixo do seu cobertor uma boneca e a entregou para a filha, dizendo: "Escute, Vassilíssuchka! Lembre-se e cumpra as minhas últimas palavras. Eu estou morrendo e, com a minha benção materna, deixo para você esta boneca, mantenha-a sempre com você e não a mostre para ninguém, mas quando lhe ocorrer alguma desgraça, dê a ela o que comer e lhe peça um conselho. Ela comerá e dirá a você como resolver as infelicidades.” Em seguida, a mãe beijou a filha e morreu.

Após a morte da sua mulher, o mercador, como deve ser, entristeceu-se, mas depois começou a pensar em se casar novamente. Ele era uma boa pessoa e não havia empecilhos para conseguir uma noiva, dentre todas as pretendentes a que mais lhe agradava era uma viuvinha. Ela já tinha idade e duas filhas quase com a mesma idade de Vassilíssa, deveria ser então uma dona-de-casa e mãe experiente. O mercador casou-se com a viuvinha, mas se enganou e nela não encontrou uma boa mãe para sua Vassilíssa. Vassilíssa era a mais bela da sua aldeia, a madrasta e suas filhas invejavam a sua beleza e a atormentavam com todos os tipos de trabalho para que ela de tanto trabalhar emagrecesse e de vento e sol enegrecesse, realmente isso não era vida!

Vassilíssa tudo agüentou sem se queixar, e a cada dia ela se tornava mais bela e mais rechonchuda, enquanto isso, a madrasta e suas filhas emagreciam e ficavam feias de raiva, embora sempre vivessem de braços cruzados como se fossem fidalgas. Como isso acontecia? Vassilíssa era ajudada por sua boneca. Sem ela, a moça não daria conta de tanto trabalho! Em compensação, às vezes, ocorria da própria Vassilíssa não comer e reservar para a bonequinha o melhor pedacinho, e, à noite, enquanto todos iam se deitar, ela se trancava na despensa onde vivia e oferecia comida à bonequinha, repetindo: “Sirva-se, bonequinha, coma e a minha desgraça ouça! Eu vivo na casa de meu pai, não tenho nenhuma alegria e a maldosa madrasta quer acabar comigo. Ensine-me como ser e viver e o que fazer?” A bonequinha comia e depois dava a ela os conselhos, confortando-a na desgraça. Pela manhã, a bonequinha realizava todo o trabalho para Vassilíssa, que somente descansava na sombra fresca e colhia florzinhas, já tendo os canteiros sachados, os repolhos regados, a água carregada e a piétch aquecida. A 
bonequinha ainda indicava para Vassilíssa uma erva contra queimaduras de sol. Para ela, era bom viver com a bonequinha.

Passados alguns anos, Vassilíssa cresceu e ficou em idade de casar-se. Todos os pretendentes na cidade interessaram-se por ela, e para as filhas da madrasta ninguém nem olhava. A madrasta irritava-se cada vez mais e a todos os pretendentes respondia: “Não caso a mais nova antes das mais velhas!” e mandando embora os pretendentes, descontava a sua raiva em Vassilíssa, espancando-a.

Eis então que certa vez, o mercador foi obrigado a partir de casa por um longo período por assuntos de negócios. A madrasta mudou-se então para outra casa, e perto dessa casa havia uma densa floresta, e na floresta em uma clareira havia uma isbazinha, e na isbazinha vivia a Baba-Iagá: ela não permitia que ninguém se aproximasse e comia as pessoas como frangos. Morando na nova casa, a mulher do mercador volta e meia enviava a odiada Vassilíssa à floresta por qualquer coisa, mas ela sempre retornava para casa sã e salva: a bonequinha lhe indicava o caminho e não permitia que ela se aproximasse da isbazinha da Baba-Iagá.

Chegou o outono. A madrasta deu a todas as três moças trabalhos noturnos: a uma obrigou a fazer renda, a outra a tricotar meias, e a Vassilíssa a fiar, a cada uma deu uma tarefa. A madrasta apagou a luz em toda a casa, deixando somente uma velinha lá onde as moças trabalhavam e foi dormir. As moças estavam trabalhando e então a velinha começou a soltar fumaça, uma das filhas da madrasta pegou uma pinça para arrumá-la, mas, em vez disso, por ordem da mãe, como se por acaso, ela apagou a velinha. "O que faremos agora?”, falaram as moças. "Não há luz na casa toda, e ainda não terminamos nossas tarefas. É preciso correr até a Baba-Iagá para conseguir fogo!” - “Os meus alfinetes me iluminam!”, disse aquela que tecia a renda. - “Eu não irei.” - “Eu não irei”, disse a que tricotava as meias. - “As minhas agulhas de tricô me iluminam!” - "Vá você atrás do fogo”, gritaram ambas. "Vá até a Baba-Iagá”, e empurraram Vassilíssa para fora do cômodo em que estavam.

Vassilíssa foi para a despensa, colocou diante da boneca o jantar e disse: "Sirvase, bonequinha, coma e minha desgraça ouça. Estão me mandando pegar fogo com a Baba-Iagá, a Baba-Iagá irá me comer!” A bonequinha comeu e seus olhos começaram a brilhar como duas velinhas. "Não tenha medo, Vassilíssuchka”, disse ela - "Vá para onde estão lhe mandando, somente carregue-me sempre com você. Estando comigo 
nada lhe acontecerá na casa da Baba-Iagá.” Vassilíssa aprontou-se, colocou sua bonequinha no bolso e, depois de fazer o sinal da cruz, foi para a densa floresta.

Ela caminhava e tremia de medo. De repente, passou a galope por ela um cavaleiro: ele era branco, vestia-se de branco, montava um cavalo branco e o arreio do cavalo era branco. Começou a amanhecer.

Ela foi em frente, quando passou a galope outro cavaleiro: ele era vermelho, vestia-se de vermelho e estava sobre um cavalo vermelho. Começou a nascer o sol.

Vassilíssa andou a noite inteira e o dia inteiro, somente na noite seguinte chegou até a clareira, onde se encontrava a isbazinha da Iagá-Baba, a cerca ao redor da isbá era feita de ossos humanos, na cerca estavam fincados crânios humanos com olhos; em vez de batentes no portão: pernas humanas; em vez de ferrolho: braços; em vez de fechadura: uma boca com dentes afiados. Vassilíssa ficou aturdida de terror e paralisada. De repente, passou novamente um cavaleiro: ele era negro, vestia-se inteiro de negro e estava sobre um cavalo negro, ele aproximou-se a galope do portão da BabaIagá e desapareceu como por encanto. Chegou a noite. Mas a escuridão não durou muito: os olhos de todos os crânios da cerca começaram a brilhar, e toda a clareira se iluminou como se fosse pleno dia. Vassilíssa tremia de medo, mas não sabendo para onde correr, não saiu do lugar.

Logo em seguida, ouviu-se na floresta um barulho horrível: as árvores trepidavam, as folhas secas estalavam, quando saiu da floresta a Baba-Iagá, ela vinha no pilão, com o socador açoitava e com a vassoura apagava o seu rastro. Aproximou-se do portão, parou, farejou ao seu redor e gritou: “Fu, fu! Eu sinto cheiro de russo. Quem está aqui?” Vassilíssa aproximou-se com temor da velha e inclinando-se respeitosamente para baixo, disse: "Sou eu, vovó! As filhas da madrasta mandaram-me até você para pegar fogo.” - "Muito bem”, disse a Iagá-Baba - “eu as conheço; primeiro, você vai morar aqui e trabalhar para mim, então eu lhe darei o fogo, caso contrário, eu a comerei!” Depois, voltou-se para o portão e gritou: “Ei, abram-se minhas fortes fechaduras, meu largo portão, abram-se!” O portão abriu-se e a Baba-Iagá entrou assobiando; atrás dela, entrou Vassilíssa, e depois tudo fechou-se novamente. Entrando no cômodo, a BabaIagá espichou-se e falou para Vassilíssa: “Trague-me aqui o que está na piétch, eu quero comer.”

Vassilíssa acendeu uma lasca de madeira naqueles crânios que estavam na cerca e começou a levar a comida da piétchka para a Iagá, e a comida preparada era para umas 
dez pessoas, da adega trouxe kvas, hidromel, cerveja e vinho ${ }^{1}$. A velha tudo comeu, tudo bebeu; para Vassilíssa restou apenas um pouquinho de sopa de repolho, uma pontinha de pão e um pedacinho de carne de leitão. A Iagá-Baba, indo dormir, disse: “Quando amanhã eu sair, trate de limpar o quintal, varrer a isbá, cozinhar o almoço, preparar a roupa branca e mais vá ao celeiro, pegue 1/4 de trigo e limpe-o das sujeirinhas. Mas se alguma coisa não tiver sido feita - eu a comerei!” Depois de tantas ordens, a Baba-Iagá começou a roncar, Vassilíssa colocou os restos de comida da velha em frente à boneca, banhou-se em lágrimas e falou: "Sirva-se, bonequinha, coma e meu desgosto ouça! A Iagá-Baba me deu um trabalho pesado e ameaça me comer, se eu não realizar tudo, ajude-me!” A boneca respondeu: “Não tenha medo Vassilíssa, a bela! Jante, ore e vá dormir, a manhã é mais sábia do que a noite!”

No dia seguinte, Vassilíssa acordou cedinho, mas a Baba-Iagá já tinha se levantado e olhava pela janela: viu que os olhos dos crânios estavam se apagando, eis então que passou velozmente o cavaleiro branco - e amanheceu. A Baba-Iagá saiu ao quintal, assobiou e na sua frente surgiu o pilão com o socador e a vassoura. Passou velozmente então o cavaleiro vermelho - e nasceu o sol. A Baba-Iagá sentou-se no pilão e saiu do quintal, com o socador açoitava e com a vassoura apagava o seu rastro. Vassilíssa ficou sozinha, olhou a casa da Baba-Iagá, aturdiu-se com a grande quantidade de coisas que existia e ficou pensando por qual trabalho, entre todos, ela primeiro começaria. Olhou e todo trabalho já estava feito, a bonequinha estava retirando as últimas sujeirinhas dos grãos de trigo. “Ah, você é minha salvadora!”, disse Vassilíssa para a bonequinha, "você me salvou da desgraça." "Para você restou somente preparar o almoço”, respondeu a bonequinha, enfiando-se no bolso de Vassilíssa. "Cozinhe em paz e descanse à vontade.”

Ao anoitecer, Vassilíssa pôs a mesa e ficou esperando a Baba-Iagá. Começou a cair a noite, passou velozmente atrás do portão o cavaleiro negro - e tudo escureceu, somente os olhos dos crânios brilhavam. Começaram a trepidar as árvores, as folhas começaram a estalar - vinha vindo a Baba-Iagá. Vassilíssa a recebeu. “Tudo foi ou não feito?”, perguntou a Iagá. “Queira ver você mesma, vovó!”, disse Vassilíssa. A BabaIagá tudo olhou, aborreceu-se por não ter nada do que reclamar e disse: "Então, está bem!” Depois soltou um grito: "Meus fiéis servos, amigos queridos. Moam o meu trigo!” Apareceram três pares de mãos, apanharam o trigo e o levaram embora. A Baba-

\footnotetext{
${ }^{1}$ Ver nota 18, conto 3, p. 104.
} 
Iagá comeu até fartar-se, aprontou-se para dormir e novamente deu uma ordem para Vassilíssa: “Amanhã faça o mesmo que hoje e além disso pegue a papoula do celeiro e a limpe, grãozinho por grãozinho da terra que alguém por maldade misturou neles!” Falou a velha, que se virou para a parede e começou a roncar, Vassilíssa então começou a dar de comer à sua bonequinha. A bonequinha comeu e lhe disse o que havia dito no dia anterior: “Ore a Deus e deite-se para dormir, a manhã é mais sábia do que a noite, tudo se resolverá, Vassilíssuchka!”

Na manhã seguinte, a Baba-Iagá novamente saiu do quintal no seu pilão, e Vassilíssa e a bonequinha fizeram imediatamente todo o trabalho. A velha retornou, deu uma olhada em tudo e gritou: "Meus fiéis servos, amigos queridos, extraiam o óleo da papoula!” Apareceram três pares de mão, apanharam a papoula e a levaram embora. A Baba-Iagá começou a almoçar, enquanto ela comia, Vassilíssa permanecia parada em pé e calada. "Por que você não fala nada comigo?” perguntou a Baba-Iagá. “Fica aí parada como uma muda!” - “Não ouso”, respondeu Vassilíssa, “mas se você me permite, eu gostaria de lhe perguntar uma coisa." - "Pergunte, porém nem toda pergunta leva ao bem: se você muito souber, rapidamente envelhecerá!” - “Eu quero lhe perguntar, vovó, somente sobre aquilo, que eu vi: quando eu estava vindo para cá, passou por mim um cavaleiro em um cavalo branco, ele era branco, suas vestes eram brancas: quem é ele?” - "Ele é meu dia claro”, respondeu a Baba-Iagá. "Depois passou por mim outro cavaleiro em um cavalo vermelho, ele era vermelho, vestia-se todo de vermelho, quem é ele?” - “Ele é meu solzinho vermelho!”, respondeu a Baba-yagá. “E o que significa o cavaleiro negro que passou por mim quando eu estava perto dos seus portões, vovó?” "É a minha escura noite - todos meus fiéis servos."

Vassilíssa lembrou-se dos três pares de mãos e calou-se. "Por que não pergunta mais coisas?” disse a Baba-Iagá. "Para mim já é o suficiente, você própria, vovó, disse que quem muito sabe logo envelhece” - “Muito bem”, respondeu a Baba-Iagá, “o que você pergunta é somente sobre aquilo que você viu fora do quintal, mas não dentro! Não gosto de lavar a roupa suja em público ${ }^{2}$, e os que são muito curiosos, eu os como. Agora eu lhe pergunto, como você consegue realizar o trabalho que eu lhe dou?” - "Eu sou ajudada pela benção de minha mãe”, respondeu Vassílissa. “Ah, é isso! Saia de perto de mim, filha abençoada! Eu não preciso de abençoados.” Arrastando Vassilíssa pelo cômodo, a expulsou aos empurrões para fora do portão, tirou da cerca um crânio com

\footnotetext{
${ }^{2}$ No original, o ditado ne vynossíti sora iz izbí seria “não levar o lixo para fora da isbá”.
} 
olhos de fogo, o colocou em um pau e o deu a Vassilíssa, dizendo: "Eis o seu fogo para as filhas da madrasta, pegue-o, pois por causa dele, elas mandaram você aqui.”

Vassílissa foi correndo para sua casa, iluminada pela luz do crânio, que se apagou somente com a chegada da manhã; e finalmente, ao anoitecer do outro dia, ela chegou em casa. Aproximando-se do portão, ela queria largar o crânio. Certamente lá em casa, pensou, já não devem mais precisar de fogo. Mas de repente, ela ouviu uma voz surda que vinha do crânio: “Não me largue, leve-me à madrasta!”

Ela deu uma olhada na casa da madrasta e não vendo luz em nenhuma das janelas, resolveu ir até lá com o crânio. Pela primeira vez, receberam-na carinhosamente e contaram que desde que ela partiu, elas não tinham fogo em casa: não conseguiam acendê-lo, e o que elas traziam do vizinho se apagava assim que elas entravam em casa com ele. “Talvez, o seu fogo não se apague!”, disse a madrasta. Levaram o crânio para dentro da casa, e então os olhos do crânio se fixaram na madrasta e nas suas filhas e as queimaram. Elas tentavam se esconder, mas para onde elas se atiravam, estavam os olhos seguindo-as por toda parte; ao amanhecer, elas estavam completamente queimadas como carvão; Vassilíssa foi a única a não ser tocada.

Pela manhã, Vassilíssa enterrou o crânio, trancou a casa, foi para a cidade e pediu abrigo para uma velhinha que vivia sozinha e sem família, passou a viver lá e a esperar o pai. Eis que um dia ela falou para a velhinha: "Aborrece-me ficar sentada sem nada para fazer, vovó! Saia e compre-me do melhor linho, pelo menos eu irei fiar.” A velhinha comprou um bom linho, e Vassilíssa começou então a fiar; o trabalho fluía em suas mãos, o seu fio saía liso e fino como um cabelo. Já tinha juntado bastante fio e era hora de começar o tecido, mas não se encontrava pente de tecer que servisse para o fio de Vassilíssa nem ninguém que se encarregasse de fazer um. Vassilíssa pediu ajuda para sua bonequinha, que lhe disse: “Traga-me qualquer velho pente, mais uma velha lançadeira, mais crina de cavalo, e eu farei tudo para você.”

Vassilíssa conseguiu tudo o que precisava e foi dormir, a bonequinha durante a noite preparou um excelente tear. Ao fim do inverno, o tecido estava pronto, tão fino que era possível passá-lo através do buraco da agulha. Na primavera, o pano foi branqueado e Vassilíssa disse para a velha: "Venda este pano, vovó, e pegue o dinheiro para você.” A velha deu uma olhada na mercadoria e exclamou: “Não, minha criança! Ninguém pode usar esse tecido, apenas o tsar; vou levá-lo ao palácio.” A velha foi ao palácio e ficou andando diante da janela. O tsar a viu e perguntou: “O que você quer, 
velhinha?” - “À Vossa Majestade tsar, eu trouxe uma rara mercadoria, que a ninguém, exceto a vós, eu quero mostrar!” O tsar ordenou que a velha viesse até ele e quando viu o tecido maravilhou-se. “O que você quer por ele?” perguntou o tsar. "Ele não tem preço, meu tsar! Eu o trouxe para lhe dar.” O tsar agradeceu e liberou a velha, dando-lhe presentes.

Desse tecido, o tsar queria que fizessem camisas, o tecido foi cortado, mas em nenhum lugar puderam encontrar uma costureira que se encarregasse de trabalhá-lo. Por muito se procurou por alguém, finalmente o tsar chamou a velha e disse: "Você soube fiar e tecer esse tecido, saberá então fazer camisas com ele.” - “Soberano”, disse a velha “não fui eu quem fiou nem teceu esse trabalho, ele é da moça que eu abriguei.” - "Mas então que ela costure!” A velha retornou para casa e contou tudo para Vassilíssa. "Eu sabia que esse trabalho não escaparia de minhas mãos.”, disse Vassilíssa que se trancou em seu cômodo e pôs-se a fazer o trabalho, costurou sem descansar e logo uma dúzia de camisas estava pronta.

A velha levou as camisas para o tsar e, enquanto isso, Vassilíssa lavou-se, penteou-se, vestiu-se e sentou-se à janela. Sentada, ficou esperando pelo o que aconteceria. Ela viu caminhando para o quintal um servo do tsar, ele entrou no cômodo e falou: "O soberano tsar quer ver a mestre que fez as suas camisas e recompensá-la com suas próprias mãos.” Vassilíssa foi até o palácio e se colocou diante dos olhos do tsar. Assim que o tsar viu Vassilíssa, a bela, apaixonou-se profundamente. "Não, minha bela!”, disse ele “Eu não me separarei de você, você será minha esposa.” Nesse momento, então, o tsar pegou Vassilíssa pela suas alvas mãos, sentou-a próxima a ele e celebraram o casamento. Logo o pai de Vassilíssa retornou, alegrou-se com o destino da filha e veio morar junto dela. Vassilíssa trouxe a velha para viver com ela também, e a bonequinha ela carregou no bolso até o fim da sua vida.

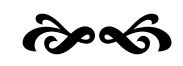




\section{Referências Bibliográficas}

AMARAL, Amadeu. Tradições populares. Com um estudo de Paulo Duarte. 3. ed. São Paulo: Hucitec; Brasília: INL, 1982.

ARRIGUCCI, Davi. Jr. Alice para adultos. In: Outros achados e perdidos. São Paulo: Companhia das Letras, 1999.

AUBERT, Francis Henrik. Novas aventuras de Askeladden. São Paulo: Edusp, 1995.

AZEVEDO, Ricardo. Como o ar não tem cor, se o céu é azul?: vestígios dos contos populares na literatura infantil. 1998. 317p. Dissertação (mestrado em Estudos Comparados das Literaturas de Língua Portuguesa), FFLCH, USP, São Paulo.

BACHELARD, Gaston. A poética do espaço. São Paulo : Martins Fontes, 2003.

BAKHTIN, Mikhail. Questões de literatura e de estética: a teoria do romance. São Paulo: Hucitec/Unesp, 1988.

BAYARD, Jean-Pierre. Histoire des légendes. Paris: PUF, 1961.

BERLIN, Isaiah. Pensadores russos. São Paulo: Companhia das Letras, 1988. . A força das idéias. São Paulo: Companhia das Letras, 2005.

BETTELHEIM, Bruno. A psicanálise dos contos de fadas. Rio de Janeiro: Paz e Terra, 1980.

CAMPBELL, Joseph. O herói de mil faces. São Paulo: Cultrix/Pensamento, 2003.

CASCUDO, Luís da Câmara. Era uma vez... In: __. Folclore no Brasil. Rio de Janeiro: Ed. Fundo de Cultura, 1967. . Literatura oral no Brasil. Belo Horizonte: Itatiaia, São Paulo: Edusp, 1984. . Geografia dos mitos brasileiros. São Paulo: Global, 2002.

. Contos tradicionais do Brasil. São Paulo: Global, 2003.

CASSIRER, Ernst. Linguagem e mito: uma contribuição ao problema dos nomes dos deuses. São Paulo: Perspectiva, 1972.

CEREPANOVA. O. A. La pronfondeur de la memoire: études ethnolinguistiques sur la Russie du Nord. Cahiers slaves, n. 2, 1999. Disponível em $<$ http://www.recherches-slaves.paris4.sorbonne.fr/Cahiers_Slaves.html>

CHOSTAKOVSKI, Paulo. História da literatura russa. São Paulo: Instituto Progresso Editorial, 1948.

COELHO, Nelly Novaes. O conto de fadas. São Paulo: Ática, 1987. . Literatura infantil. São Paulo: Moderna, 2003. 
CONSIGLIERI, Pedroso. Contos populares portugueses. São Paulo : Landy, 2001.

CONTE, Francis. Les slaves. Paris : Albin Michel, 1986.

. L'héritage païen de la Russie. Paris : Albin Michel, 2000.

DEZOTTI, Maria Celeste Consolen. A tradição da fábula: De Esopo a La Fontaine. Brasília: UnB; São Paulo: Imprensa Oficial do Estado de São Paulo, 2003.

D’ONOFRIO, Salvatore. Conto popular ou maravilhoso. In . Teoria do texto 1 -

Prolegômenos e teoria da narrativa. São Paulo: Ática, 1995.

DUMÉZIL, Georges. Do mito ao romance. São Paulo: Martins Fontes, 1992. . Mythes et dieux des indo-européens. Paris: Flammarion, 1992.

DUNDES, Alan. Morfologia e estrutura no conto maravilhoso. São Paulo: Perspectiva, 1996.

EAGLETON, Terry. Marxismo e crítica literária. Porto: Afrontamento, 1978.

EIKHENBAUM, B. et alli. Teoria da literatura: Formalistas russos. Porto Alegre: Globo, 1973.

ELIADE, Mircea. Mito e realidade. São Paulo: Perspectiva, 1972.

. O sagrado e o profano. São Paulo : Martins Fontes, 2001. . Tratado de História das religiões. São Paulo : Martins Fontes, 2002.

ETKIND, Efim; NIVAT, George et alli. Histoire de la littérature russe, Paris : Fayard, 1992, t. 1.

FRANK, Joseph. Pelo prisma russo. São Paulo: Edusp, 1992.

GENNEP, Arnold van. O folklore. Bahia: Livraria Progresso, 1950.

. Os ritos de passagem. Petrópolis: Vozes, 1978.

GOTLIB, Nádia Batella. Teoria do conto. São Paulo: Ática, 2004.

GRIMM, Jacob ; Wilhelm. Contos de Grimm. Belo Horizonte/Rio de Janeiro : Itatiaia, 2000.

GRUEL-APERT, Lise. La tradition orale russe. Paris : PUF, 1998.

HANEY, Jack. Mr. Afanassiev's naughty little secrets : Rússkie zavetnye skázki. Seefa journal, $\quad$ v. $\quad 3, \quad$ n. $\quad 2, \quad 1998 . \quad$ Disponível em $<$ http://www.angelfire.com/mt/mpzn/Zavetnye.htm>.

. Russian wondertales. Nova York: M.E. Sharpe, 2001.

KABAKOVA, G. Les représentations des odeurs dans la culture populaire slave. Cahiers slaves, n. 1, 1997. Disponível em <http://www.recherchesslaves.paris4.sorbonne.fr/Cahiers_Slaves.html>.

KOCHAN, Lionel. A formação da Rússia moderna. Lisboa: Editora Ulisséia, 1962. 
KOstIUKHIN, E. A. Magic tales that end badly. Seefa journal, v. 3, n. 2, 1998. Disponível em < http://www.arts.ualberta.ca/SEEFA/MAGTALES.HTM>

IVANITS, Linda. Russian Folk Belief. Nova York: M.E. Sharpe, 1992.

JAKOBSON, Roman. On Russian fairy tales. In: AFANÁSSIEV, A. N. Russian fairy tales. Trad. Nobert Guterman, New York: Pantheon Books, 1975, p. 631-651.

JOLLES, André. Formas simples. São Paulo: Cultrix, 1976.

JUNG, Carl. O homem e seus símbolos. Rio de Janeiro: Nova Fronteira, 1964.

LIKHATCHOV, Dimitri. Poétique historique de la littérature russe du $X$ au XX siècle. Suisse: L'âge d'Homme, 1988.

LO GATTO, Ettore. Historia de la literatura rusa. Barcelona: Luis de Caralt, 1952.

MEGALE, Nilza B. Folclore brasileiro, Rio de Janeiro: Vozes, 1999.

MELETÍSNKI, Eleazar. A poética do mito. Rio de Janeiro: Forense Universitária, 1987. . Os arquétipos literários. São Paulo: Ateliê Editorial, 1998.

. O estudo tipológico-estrutural do conto maravilhoso. In: PROPP, Vladímir, Morfologia do conto maravilhoso, Rio de Janeiro, Forense-Universitária, 1984.

ORTIZ, Renato. Românticos e folcloristas. São Paulo: Olho d’Água, 1992.

PICCHIO, Riccardo. La literatura rusa antigua. Trad. Dinko Cvitanovic. Buenos Aires: Losada, 1972.

PORTAL, Roger. Os eslavos: povos e nações. Lisboa: Cosmos, 1968.

PROPP, Vladímir. Édipo à luz do folclore. Lisboa: Editorial Vega, 1980. . Morfologia do conto maravilhoso. Rio de Janeiro, Forense-Universitária, 1984.

. As raízes históricas do conto maravilhoso. São Paulo: Martins Fontes, 1997.

RAMOS, ARTHUR. Estudos de folk-lore. Rio de Janeiro: Casa do Estudante do Brasil, 1958.

RIBEIRO, Lêda Tâmega. Mito e poesia popular. Rio de janeiro: Funarte/Instituto Nacional do Folclore, 1986.

RUTHVEN, Kenneth. O mito. São Paulo: Perspectiva, 1997.

RYBAKOV, Boris. Le paganisme des anciens Slaves. Paris : PUF, 2000.

SCHNAIDERMAN, Boris. Semiótica russa. São Paulo: Perspectiva, 1979.

SLONIM, Marc. La literatura rusa. México: Fondo de Cultura Economica, 1975.

SIMONSEN, Michèle. O conto popular. São Paulo: Martins Fontes, 1987.

SOKOLÓV, Iouri. Le folklore russe. Paris: Payot, 1945.

TODOROV, Tzvetan. Introdução à literatura fantástica. São Paulo: Perspectiva, 1992. 
VOLOBUEF, Karin. Um estudo do conto de fadas. Revista de Letras. São Paulo, v. 33, p. 99-114, 1993.

ZUMTHOR. Paul. A letra e a voz: a "literatura” medieval. São Paulo: Companhia das Letras, 1993.

WARNER, Elizabeth. Mythes russes. Trad. Gabriel R. Veyret. Paris: Seuil, 2005.

WEITZEL, Antônio Henrique. Folclore literário e lingüístico. Juiz de Fora: Editora da UFJF, 1995.

WOLFF, T. (org.). Pushkin on literature. Londres: Tehe Athlone Press, 1986.

\section{Em russo:}

AFANÁSSIEV, Alexander N. Naródnye rússkie skázki (Contos populares russos). Preparação, prefácio e comentários: Vladímir Propp. Moscou: Gossudárstvennoe Izdátelstvo Khudójestvennoi Literatury, 6ª ed., 1957. 3 vol.

. Predislóvie k I výpusku 1-go izdánia (Prefácio ao primeiro volume da primeira edição). In: Naródnye rússkie skázki. Moscou: Gossudárstvennoe Izdátelstvo Khudójestvennoi Literatury, 6ª ed., 1957. 3 vol.

Predislóvie k IV výpusku 1-go izdánia (Prefácio ao quarto volume da primeira edição). In: Naródnye rússkie skázki. Moscou: Gossudárstvennoe Izdátelstvo Khudójestvennoi Literatury, 6ª . ed., 1957. 3 vol.

- Predislóvie k 2-mu izdániiu (Prefácio à segunda edição). In:

Naródnye rússkie skázki. Moscou: Gossudárstvennoe Izdátelstvo Khudójestvennoi Literatury, $6^{\text {a }}$. ed., 1957. 3 vol.

. Naródnye rússkie skázki (Contos populares russos). Preparação: L. G. Barág e N. V. Nóvikov. Moscou: Naúka, 7ª ed., 1984. 3 vol.

. Narod-khudójnik: Mif, folklor, literatura (Povo artista: Mito, folclore e literatura). Organização e preparação: A. L. Naliépin. Moscou, Soviétskaia Rossía, 1986.

. Naródnye rússkie leguiéndy (Lendas populares russas). Novossibírsk: Naúka, 1990.

. Naródnye rússkie skázki ne dliá petcháti, zaviétnye poslóvitsy i pogovórki (Contos populares russos não para publicação, provérbios e ditados proibidos). Moscou: Ladomir, 1997. 
Rússkie zaviétnye skázki (Contos populares russos proibidos). Moscou: Terra, 2000.

. Mifológuia driévnei Russi (Poetítcheskie vozzriéniia slavián na priródu)

Mitologia da Rússia antiga. (Concepções poéticas dos eslavos sobre a natureza). Moscou: Eksmo, 2005.

BARKOVA, A. L. Verovániia driévnikh slavián (Antigas crenças eslavas) In: Entsiklopiédiia Slaviánskaia mifológuia i epos (Enciclopédia do epos e mitologia eslava). Disponível em <http://mith.ru/alb/slavic/slav6.htm>

CHÁNINA, N. F. Skázka v tvórtchestve rússkikh khudójnikov. (O conto popular na obra de pintores russos). Moscou: Iskússtvo, 1969.

FLETCHER, D. O gossudárstve rússkom (Sobre o estado russo). Disponível em <http://www.vostlit.info/Texts/rus4/Fletcher/frametext4.htm>

IVANOV, A. Istória - tól’ko formát (História apenas um formato). Nezavíssimaia 08.09.2005. Disponível em <http://exlibris.ng.ru/fakty/2005-0908/1_history.html>

KRASNÓVOI, M. A. (org.). Ruskii folklor (Folclore russo). Moscou: Olimp, 1999.

MELETÍNSKI, E. Mif i Skázka (Mito e conto popular). Disponível em $<$ http://www.ruthenia.ru/folklore/meletinsky11.htm>

. Guerói volchiébnoi skázki (O herói do conto de magia). Moscou/São Petersburgo: Akadiémiia Issliédovanii Kul’tury/Traditsiia, 2005.

NALIÉPIN, A. L. Arkhiológ slaviánskikh driévnostei (Arqueólogo da antiguidade eslava). In: AFANÁSSIEV, A. N. Narod-khudójnik : Mif, folklor, literatura (Povo artista: Mito, folclore e literatura). Organização e preparação: A. L. Naliépin. Moscou, Soviétskaia Rossía, 1986.

NEKLIÚDOV, S. I. Potchemú skázki odinákovye? (Por que os contos populares são semelhantes?). Jiváia Stariná, 2004, n. 1, Disponível em $<$ http://www.ruthenia.ru/folklore/neckludov17.htm>

NIKÍFOROV, A. I. Skázka (O conto popular). In: Literatúrnaia entsiklopiédiia (Enciclopédia literária). Moscou: 1929-1939, t. 10. Disponível em <http://febweb.ru/feb/litenc/encyclop/lea/lea-7681.htm>

NÓVIK, E. S. Sistema personájei rússkoi volchiébnoi skázki (Sistema de personagens do conto popular de magia russo). Disponível em <http://www.ruthenia.ru/folklore/novik8.htm> 
PROPP, V. Predislóvie (Prefácio). In: AFANÁSSIEV, A. N. Naródnye rússkie skázki

(Contos populares russos). Moscou: Gossudárstvennoe Izdátelstvo Khudójestvennoi Literatury, 6a . ed., 1957. 3 vol. . Rússkaia skázka (O conto popular russo). Moscou: Labirint, 2005.

SIÁZI, A. M. Nácha jisn’ (Nossa vida). Disponível em <http://www.sati.archaeology.nsc.ru/Museums/DecorateArt/intro.html>

SOKOLÓV, I. Jizn i naútchnaia diéiatelnost A. N. Afanássieva (Vida e atividade científica de A. N. Afanássiev). In: AFANÁSSIEV, A. N. Naródnye rússkie skázki. (Preparação): M. K. Azadovski, N. P. Andriéev e I. N. Sokolóv, 5a ed., Leningrad: Academia, 1936.

TCHISTÓV, K. V. Baba-Iagá. Jiváia stariná, 1997, n. 2 (14).

USSATCHIÓV. A. (org.). Bolcháia kníga Báby-Iaguí (O grande livro da Baba-Iagá). Moscou: Oniks, 2006.

VERIJNIKOVA, T. (org.). Ivan Bilíbin. São Petersburgo: Avrora, 2001.

\section{Traduções das obras de Afanássiev:}

AFANÁSSIEV, A. N. Contos populaires russes en peintures sur laque de Palekh, Fedoskino et Kholouï. Trad. N. Moultatouli e S. Vassilieva. Saint-Pétersbourg : Editions d’art Yarki Gorod, 2006.

. Contos de fadas russos. Trad. Dinah de Abreu Azevedo. São Paulo: Landy, 2002-2003, 3 vol.

. Contos populares russos. Seleção e organização: José Viale Moutinho. São Paulo : Landy, 2002.

Les contes populaires russes. Trad. Lise Gruel-Apert. Paris: Maisonneuve \& Larose, 1988, t. 1 ; 1991, t. 2 ; 1992, t.3.

Cuentos populares rusos. Trad. E. Pomerantseva. México: Palomar, s.d.

. Russian fairy tales. Trad. Nobert Guterman, New York: Pantheon Books, 1975.

\section{Obras de referência:}


DAL, V. I. Tolkóvyi slovár jivógo velikorússkogo iazyká (Dicionário da língua grãrussa viva). Disponível em <http://www.booksite.ru/fulltext/dal/dall/>.

SLOVÁR Slaviánskoi Mifológuii (Dicionário de mitologia eslava). Disponível em $<$ http://www.pagan.ru/mith/>.

MIFOLÓGUITCHESKII Slovár (Dicionário mitológico). Disponível em $<$ http://myths.kulichki.ru/>.

WIKIPEDIA. Disponível em <http://ru.wikipedia.org/wiki>. 


\section{Glossário}

Bánia - a tradicional bánia é uma construção à parte, mas próxima da casa principal, sua aparência é de uma pequena isbá e, sempre que possível, localiza-se perto de algum lago ou rio.

Seu interior é constituído de cômodos, o primeiro geralmente é destinado a se despir, um segundo é dedicado ao banho a vapor, onde as pessoas sentam-se ou deitamse sobre bancos de madeira, dispondo de baldes com água para se lavar e maços de folhas de bétula ou carvalho que são batidos sobre o corpo com o objetivo de relaxar, ativar a circulação e eliminar as toxinas. Alguns observadores estrangeiros, ao visitarem a Rússia, consideravam esse hábito um verdadeiro flagelo.

O aquecimento da bánia ocorre muitas horas antes do seu uso, um forno (kámenka) alimentado por lenha produz calor suficiente para esquentar todo o ambiente. Pedras escaldantes, presentes no cômodo do banho a vapor, são molhadas produzindo o vapor. Na seqüência, é necessário o contraste térmico. Para isso, joga-se água fria sobre o corpo ou ainda os mais radicais lançam-se num rio ou lago próximo ou até mesmo sobre a neve.

Durante sua estadia nos anos 1920, numa pequena cidade de Nijni-Nóvgorod, Pierre Pascal, intelectual francês e eslavista, descreveu a bánia da seguinte maneira:

Les bains... (bani) doivent être à la fois loin des habitations à cause du danger d'incendie, et à proximité de l'eau, ruisseau, étang ou marais [...]. La première pièce (predbannik) est éclairée par une minuscule fenêtre [...] du cotê opposé à la porte d'entrée, qui est très basse ; elle a un banc et des chevilles à pendre les vêtements, car c'est ici qu'on se déshabille. On passe de là dans le seconde pièce par une porte encore plus basse. Là est le poêle : un four de brique avec sa cheminée, dans lequel est encastrée une chaudière. Le plancher est intentionnellement mal joint. Comme mobilier, trois bancs s'étageant, le plus haut proche du plafond, et des tonneaux qu'on se remplit de l'eau bouillie dans la chaudière. Dans les bains plus anciens... la vapeur est obtenue en portant au rouge de grosses pierres sur lesquelles on projette de l'eau froide. De toute façon, le baigneur s'allonge d'abord sur la banquette inférieure, où il s'asperge d'eau chaude... et se savonne; puis il monte sur la banquette médiane et sur la banquette supérieure, où la vapeur est la plus forte. Quand il n'y peut plus tenir, il redescend. Pour activer la circulation, on se fouette avec de petits balais de branches de jeune bouleau... ${ }^{1}$

\footnotetext{
${ }^{1}$ Pascal, P. apud Conte, F. Les slaves, p. 150. "Os banhos (bani) devem estar ao mesmo tempo longe das habitações por causa do perigo de incêndio e perto da água, de um riacho, lagoa ou charco [...]. O primeiro cômodo (predbannik) é iluminado por uma janela minúscula [...] do lado contrário à porta de entrada que é muito baixa; há um banco e cabides para pendurar as roupas, pois é aqui que se despe.
} 
Por se tratar, assim como a piétch, de um dos símbolos da cultura russa, principalmente da vida no campo, e pelo seu uso constituir praticamente um ritual, a bánia também se tornou um lugar rodeado de crenças.

Acreditava-se que a bánia era um lugar impuro, habitada por representantes de forças impuras, entre eles, o bánnik ${ }^{2}$ ou bannaia, na versão feminina. Por isso, para freqüentá-la era necessário alguns "cuidados" prévios, como, não entrar na bánia com cruzes no pescoço. Para não irritar o bánnik, que vive atrás das pedras do forno ou debaixo dos bancos, não se deve bater, falar alto ou cantar, durante o banho; já para ganhar a sua simpatia, é preciso lhe oferecer um pedaço de pão de trigo com sal.

Muitos casos de sufocamento ou queimaduras dos freqüentadores das casas de banho eram explicados como sendo uma ação de um bánnik irritado. Até mesmo os incêndios dessas construções eram assim justificados. Dessa forma, mais uma vez, notase a clara relação da vida cotidiana russa e suas crenças.

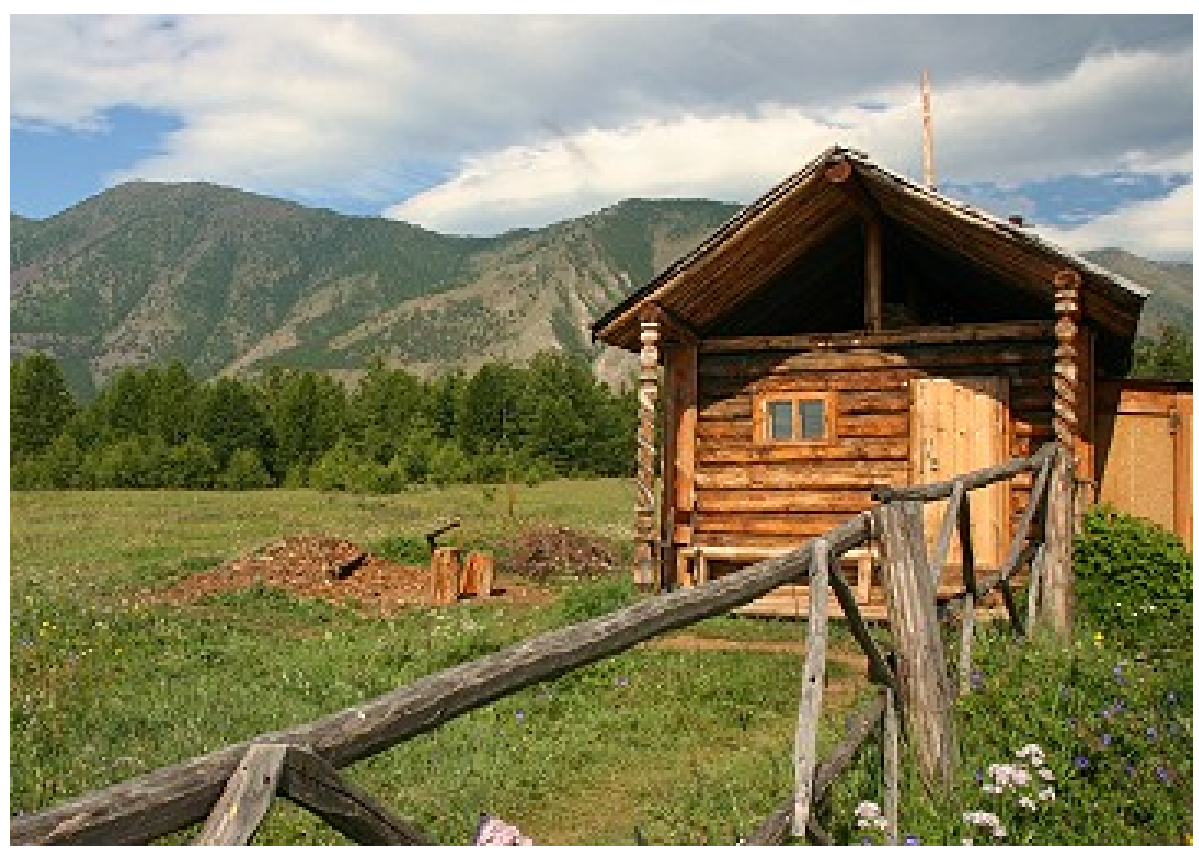

Imagem externa de uma bánia. Disponível em <http://perso.orange.fr/groenlanddisko/siberie-baikal/Bania.htm>.

\footnotetext{
Passa-se desse para o segundo cômodo por uma porta ainda mais baixa. Nele está o forno: um forno de tijolos com chaminé, na qual está embutida uma caldeira. $\mathrm{O}$ assoalho intencionalmente não é bem unido. Como mobiliário, três bancos se dispõem em andares, o mais alto fica próximo do teto e dos baldes que são enchidos com água fervente na caldeira. Nos banhos mais antigos..., o vapor é obtido jogando-se água fria sobre grandes pedras escaldantes. De todo modo, aquele que toma banho se estica inicialmente sobre o banco inferior, onde ele se molha com água quente... e se ensaboa, depois ele sobe sobre o banco do meio e sobre o superior onde o vapor é mais forte. Quando não suporta mais ficar lá, desce. Para ativar a circulação, bate-se com pequenas vassouras feitas de ramos de bétula jovem."

${ }^{2}$ Interessante notar que o nome dos espíritos impuros traz o lugar onde eles habitam. Bannik, de bánia, domovói, de dom (casa), liéch, de les (floresta) etc.
} 


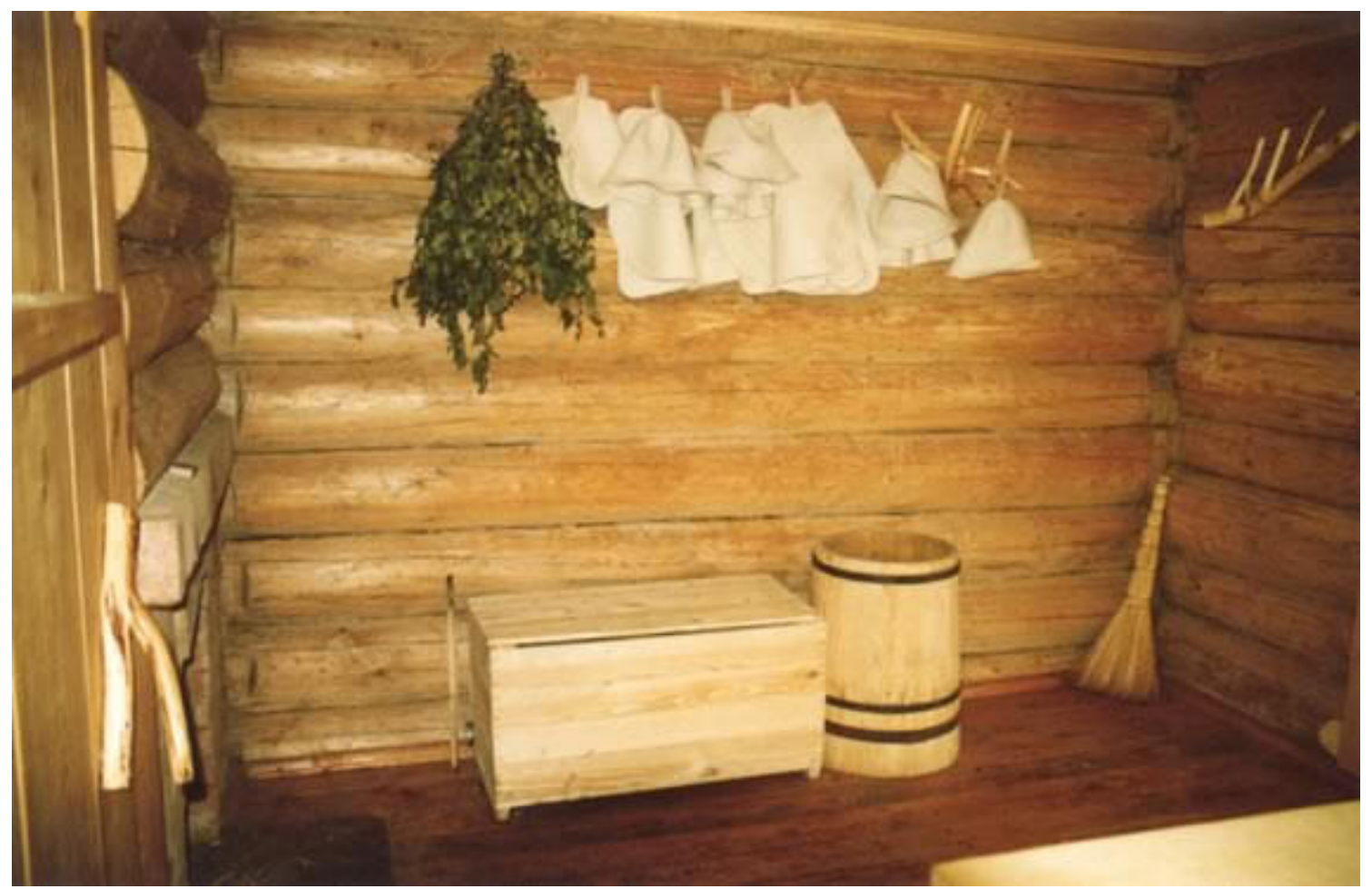

Interior de uma bánia. Disponível em < http://www.geocities.com/mushkah/Banya.html>

Bogatýr - de origem tártara, é o nome dado ao herói épico das bilinas (canções épicas) russas. Provido de grande bondade para com seus compatriotas, possui descomunal força física e de caráter, símbolos do poder, patriotismo e amor ao povo russo, e, acima de tudo, a plena consciência de sua responsabilidade em defender a terra russa dos invasores representados pelos nômades em geral, pelos mongóis ou por seres fabulosos como dragões. Os três mais conhecidos bogatyrí são Ilya Múromiets, Aliocha Popóvitch e Dobrýnia Nikítitch.

Ilya Múromiets é o mais glorioso dos três. Filho de camponês, mesmo desprezado pela nobreza, é tomado pelo patriotismo e defende a Rus, sua atitude não é em defesa da nobreza, mas da santa Terra Russa. Defensor dos pobres e oprimidos, Ilya não pensa em receber butins, glórias e riquezas, mas somente em fazer o bem público.

Aliocha Popóvitch parece ter recebido modificações ao longo dos tempos. Inicialmente era um típico bogatýr hábil e audacioso, pronto para defender a Pátria. Algumas obras, porém, relatam-no como produto de sua origem paterna (Popóvitch, filho do pope), ou seja, por vezes é possível encontrá-lo, segundo a visão popular, dotado de inveja, interesse material, vaidade. Seu principal inimigo é Tugárin Zmiévitch, um ser monstruoso que muitas vezes representa os invasores das estepes. 
Dobrýnia Nikítitch é visto como o bogatýr diplomata, reúne bravura e polidez, possui o dom da palavra e espírito refinado, toca gúsli, compõe e canta versos. Em uma das bilinas dedicadas a esse herói, pode-se encontrar um tema presente também na Odisséia, a volta do marido no momento em que os pretendentes de sua mulher estão próximos a tomar o poder. Dobrýnia se ausenta de casa por doze anos. Por tanto tempo longe, o príncipe Vladímir convence a mulher de Dobrýnia, Natasha, a se casar com Aliocha Popóvitch. No momento em que o casamento será celebrado, Dobrýnia chega disfarçado de skomorókh e, quando começa a cantar, é reconhecido pela sua mulher e imediatamente faz justiça aos traidores.

Apesar de cada bogatýr apresentar as suas peculiaridades, o fato comum é que todos são defensores do território russo. A cada um deles são dedicadas diversas bilinas.

Ilya, Aliocha e Dobrýnia são os três bogatyrí mais conhecidos. Porém, há diversos outros até mesmo na figura de mulheres como Vassilíssa Mikúlitchna.

Embora típico das bilinas, é possível encontrar tais personagens também nos contos populares. Além disso, por extensão, a palavra bogatýr passou a ser empregada a qualquer homem provido de grande força física, valentia e ousadia. O herói dos contos populares é muitas vezes assim chamado, entretanto, isso não significa que ele defenderá a pátria dos inimigos, como os acima citados, mas sim que é um guerreiro valente, com modos heróicos.

No caso dos bogatyrí Ussýnia, Gorýnia e Dubýnia, cujo material a respeito é escasso, resumindo-se quase que somente ao próprio conto, nota-se que eles são figuras ligadas muito mais à natureza e à sua representação do que aos tradicionais cavaleiros defensores da Pátria.

Esses três personagens trazem em seus nomes os seus significados e funções.

Ussýnia - vem de ussý, bigode - sua especialidade é barrar o trajeto das águas com a boca, pescar com o bigode, cozinhar na língua e comer.

Gorýnia - vem de gorá, montanha - é responsável por igualar o caminho, arrancando montanhas e as colocando em barrancos.

Dubýnia - vem de $d u b$, carvalho - dedica-se a alinhar os carvalhos, puxando da terra os que estão baixos e empurrando para a terra os que estão altos.

Embora seus nomes estejam relacionados a elementos da natureza, não possuem o papel de protetores dos lugares aos quais estão ligados, mas sim de modificadores da 
ordem. No conto, apresentem-se como acompanhantes do herói, mas logo revelam seu caráter negativo ao traírem o herói ${ }^{3}$.

Piétch ou piétchka - construção típica do cenário campesino russo; ocupando um lugar central na casa do camponês, geralmente, é disposta de maneira a aquecer toda a casa e servir como uma divisória entre os cômodos. Possui as mais variadas funções, além de assar e cozinhar alimentos, servia ainda como dormitório - sua superfície superior era usada como leito - aquecedor e até lavatório.

Sua aparência está muito longe dos nossos atuais fogões e fornos, talvez a imagem da nossa cultura mais próxima da piétch seja o antigo forno a lenha. Porém, a piétch é algo extremamente peculiar, chegando muitas vezes a ocupar boa parte da isbá. Mantida acesa, funcionava como um aquecedor, seu tamanho possibilitava que crianças fossem banhadas no seu interior, há relatos de pessoas que conseguiram até mesmo escapar de capturas nazistas, durante a Segunda Guerra Mundial, escondendo-se no seu interior ${ }^{4}$.

A parte superior da piétch é plana e longa, formando uma plataforma, onde é possível se deitar e dormir, este lugar chamado em russo de lejánka era muito disputado principalmente por conservar o calor. Tal costume, tão estranho ao leitor, é frequentemente citado nos contos populares em que os personagens dormem ou ficam sentados sobre a piétch.

Os bons construtores de piétch dispunham de muita admiração entre os habitantes das aldeias russas, pois possuir um exemplar de qualidade poderia tornar-se vital.

Por tudo isso, é possível imaginar como essa construção é cercada de valor simbólico, sua sacralidade está extremamente ligada à sua capacidade de oferecer elementos essenciais à sobrevivência: a feitura dos alimentos, o aquecimento da casa, o lugar para dormir etc.

Dessa forma, acrescido do fato de a piétch ser manipulada por mulheres, a sua parte interior (o forno) é comparada simbolicamente a um útero, gerador de vida. Porém, a piétch como um todo está ligada ao ciclo de vida e morte, de transformações, isso se pensarmos no alimento cru que se torna cozido ou na lenha que vira cinzas e em sua fumaça que se dirige ao céu.

\footnotetext{
${ }^{3}$ Ivanov, V. V; Toporov, V. N. Gorýnia, Dubýnia, Ussýnia in Mifológuitcheskii Slovar. Disponível em $<$ http://myths.kulichki.ru/>

${ }^{4}$ Wikipedia. Disponível em <ru.wikipedia.org/wiki/Русская_печь $>$
} 
Um ritual muito curioso, que pode ilustrar essa idéia, é o chamado Perepekánie Rebiónka, ou seja, "reassamento do bebê". Esse ritual, talvez seja o símbolo máximo da piétch como um lugar de morte e renascimento. Nele, o bebê, agasalhado e preso em uma pá, era três vezes rapidamente introduzido na piétch aquecida. Acreditava-se que assim as crianças doentes, geralmente com raquitismo ou atrofias, ficariam curadas de seus males, como se a criança doente morresse e uma sadia renascesse ${ }^{5}$.

No âmbito espacial, a piétch representa tanto o centro, por sua importância ao manter o fogo doméstico e pela sua posição na casa, quanto a fronteira. Neste último caso, as chaminés da piétch são vistas como canais para o mundo exterior, onde se inclui o outro mundo e os seres sobrenaturais. Acredita-se que elas servem como passagem do mundo interior para o exterior e vice-versa, sendo uma via de acesso para diabos, bruxas, alma dos mortos, doenças. Assim, a piétch pode adquirir também um caráter ameaçador, tendo seu significado simbólico adaptado de acordo com os rituais. Se nos casamentos ela pode ser vista como símbolo do útero produtor; nos funerais, as suas chaminés representam o caminho da alma do morto ao outro mundo. Como exemplo dos diferentes significados que a piétch recebia de acordo com o ritual, pode-se citar o costume russo de olhar dentro do forno da piétch. Se isso fosse feito após um enterro, servia como forma de se libertar da saudade e do medo do falecido, porém, se tal hábito fosse feito após um casamento pela recém-esposa, significava sua vontade de que os pais do marido morressem.

Diversas outras crenças cercam a piétch e seus acessórios, como a de aquecê-la para que as tempestades se acalmassem ou a de jogar pás de pão ou atiçadores no quintal ou colocá-los em forma de cruz para proteger as plantações dos granizos. Ao se ver a formação de uma tempestade, devia-se fechar a chaminé para que o diabo ou outra força impura não se escondesse no seu interior ou para que os raios não caíssem sobre a casa.

O fogo interno da piétch era visto como uma criatura viva, sendo sempre mantido aceso, mesmo à noite, em forma de brasa. Quando se mudava de uma casa para outra, era costume levar as brasas, acreditando-se assim transportar a prosperidade para o novo lar. Essa era uma das formas também para se atrair o domovói, espécie de duende doméstico que gosta de ficar debaixo da piétch, servindo tanto como um espírito protetor da casa quanto um traquinador, caso não seja agradado pelos donos.

\footnotetext{
${ }^{5}$ Slovár Slaviánskoi Mifológuii. Disponível em <http://www.pagan.ru/>
} 
A idéia de fogo interno como ser vivo pode ser observada numa historieta que narra a conversa entre dois fogos, nela um deles dizia não ser bem cuidado por sua dona e, por isso, planejava um incêndio. Talvez essa fosse uma forma utilizada para explicar os incêndios, mostrando como o cotidiano rural russo era completamente vinculado às crenças.

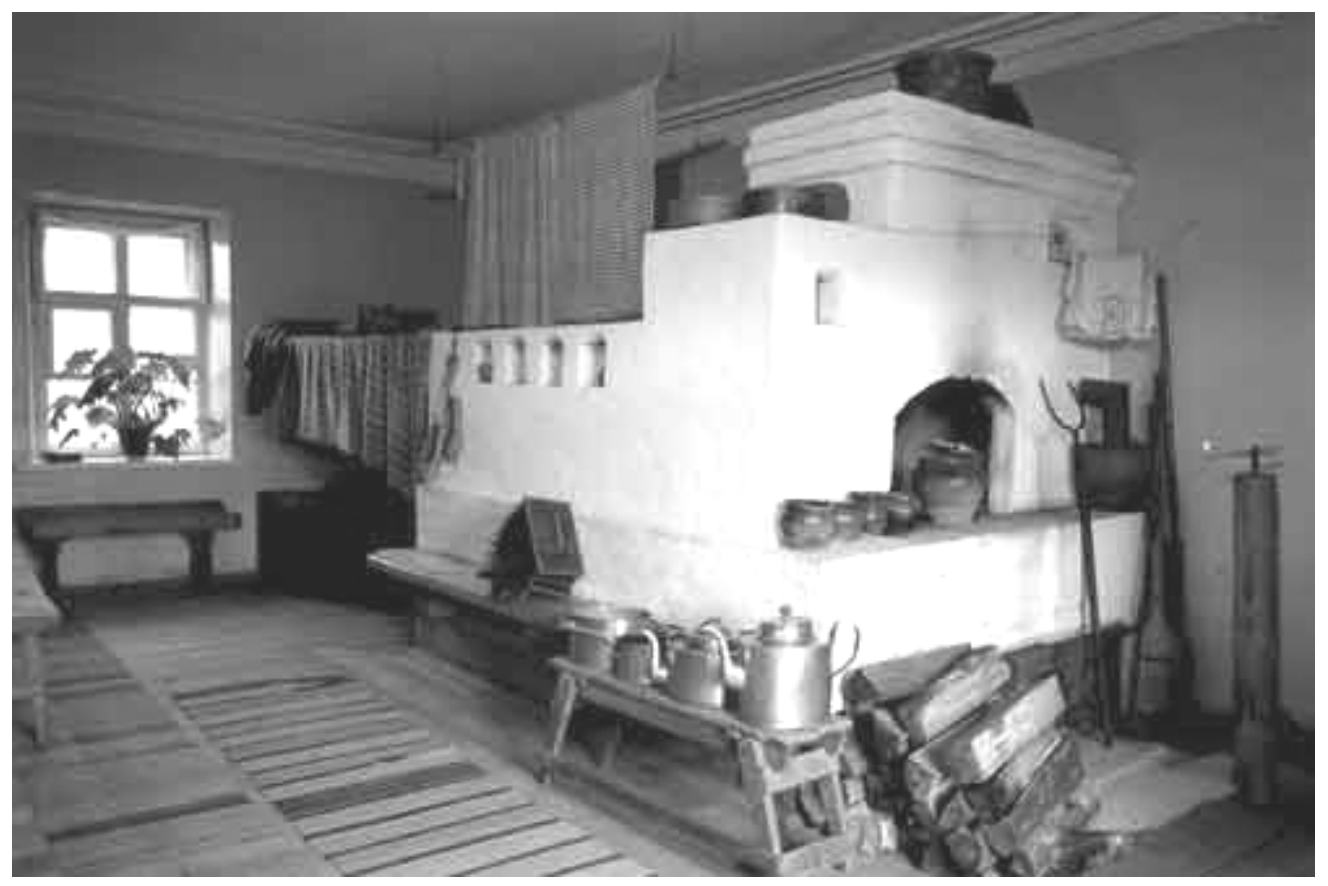

Uma piétch russa antiga e seus acessórios. Disponível em $<$ http://otchizna.info/archiv2006/otchizna5/pechka.htm>

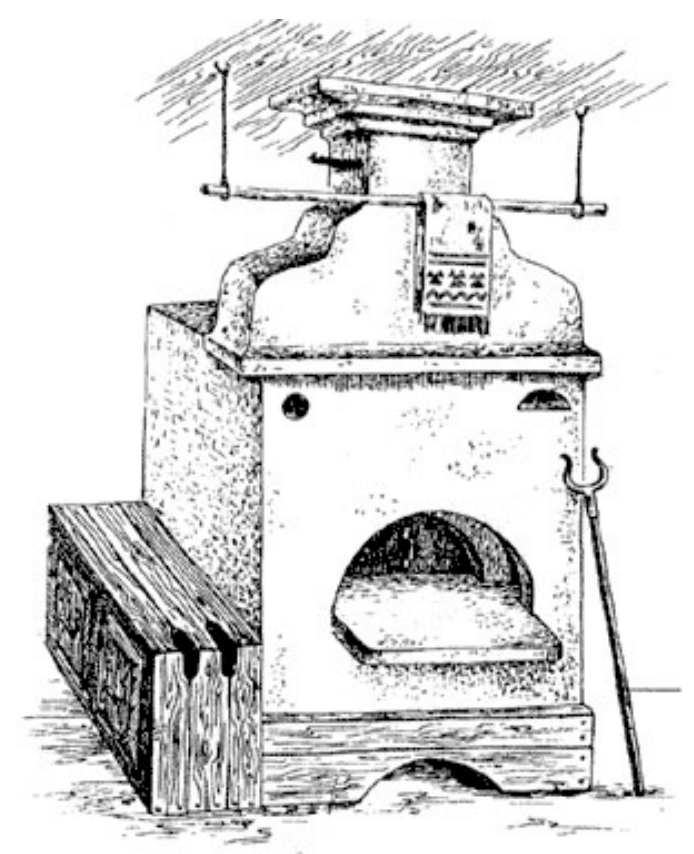

Disponível em $<$ http://www.gramota.ru/book/village/map6.html > 


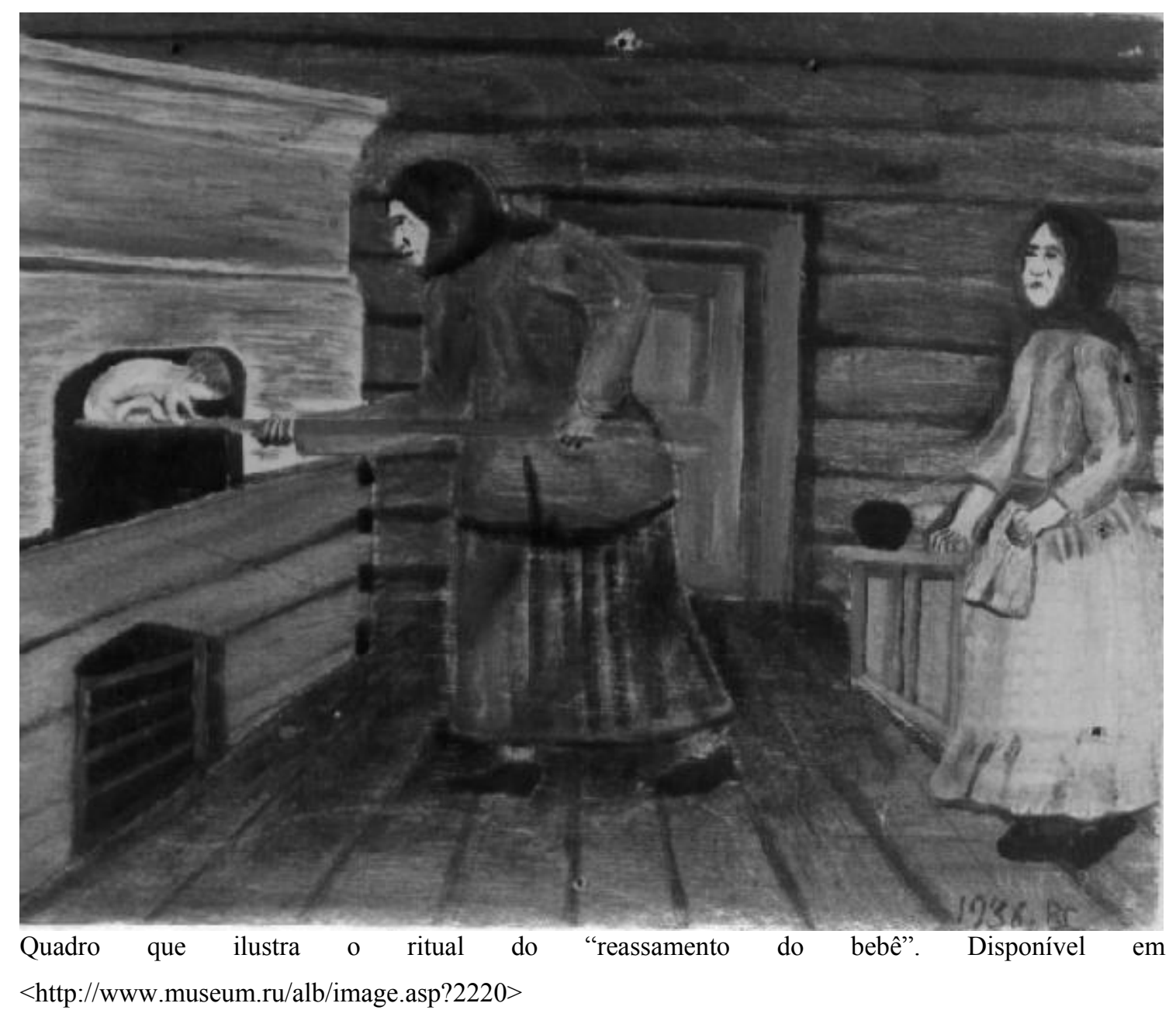




\section{Anexo}

\section{Imagens da Baba-Iagá}

Diversos episódios dos contos populares e de outras obras de criação popular foram retratados em diferentes expressões artísticas. Representantes das artes plásticas, incluindo o antigo lubók ${ }^{1}$ e o pálekh ${ }^{2}$, do cinema, da música, do desenho animado lançaram a sua interpretação sobre cenas e personagens das obras populares. Limitarnos-emos a apresentar aqui apenas algumas das imagens mais conhecidas dedicadas à Baba-Iagá, imagens que se tornaram clássicas pela sua divulgação e preciosidade. É curioso notar as diferentes visões que a figura desse personagem recebeu, das versões mais horripilantes de Vasnetsóv e Bilíbin à simpática velhinha presente nas ilustrações de edições atuais de contos, observa-se uma tendência a transformar sua imagem ameaçadora em inofensiva. Como uma bondosa senhorinha, a Iagá participa, atualmente, até mesmo de séries de livros didáticos, auxiliando as crianças a aprender línguas estrangeiras ou ainda a ler ou contar.

Nas artes plásticas, a Iagá já estava presente nas primeiras ilustrações feitas para as edições de literatura de lubók.

\footnotetext{
${ }^{1}$ Ver capítulo 1 deste trabalho, nota 14.

2 Técnica de pintura de miniaturas sobre peças banhadas de laca.
} 


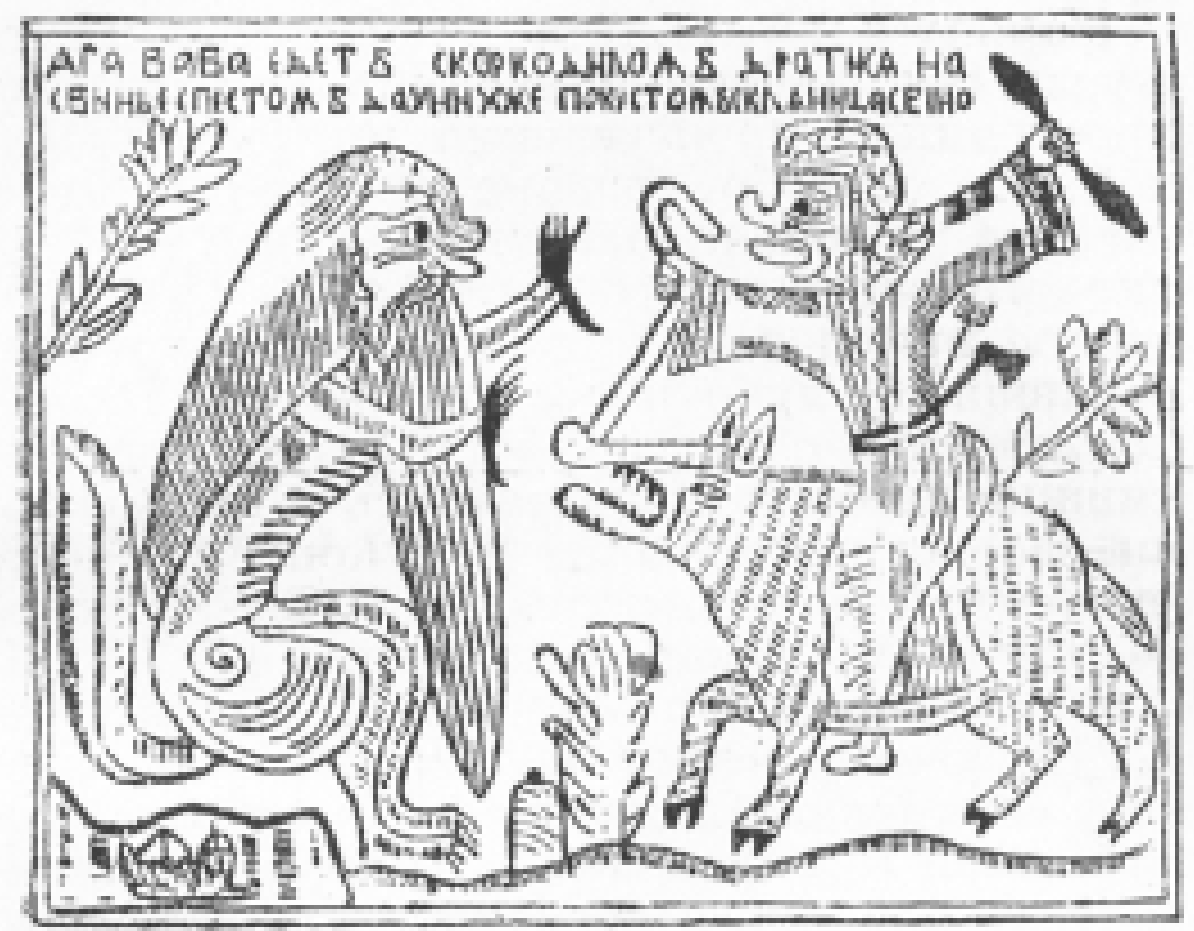

Iagá-Baba briga com crocodilo (gravura em madeira, 1766), da coleção de Rovinski. Disponível em < http:/www.eunnet.net/oldbelief/main/ch4/4_2.htm>

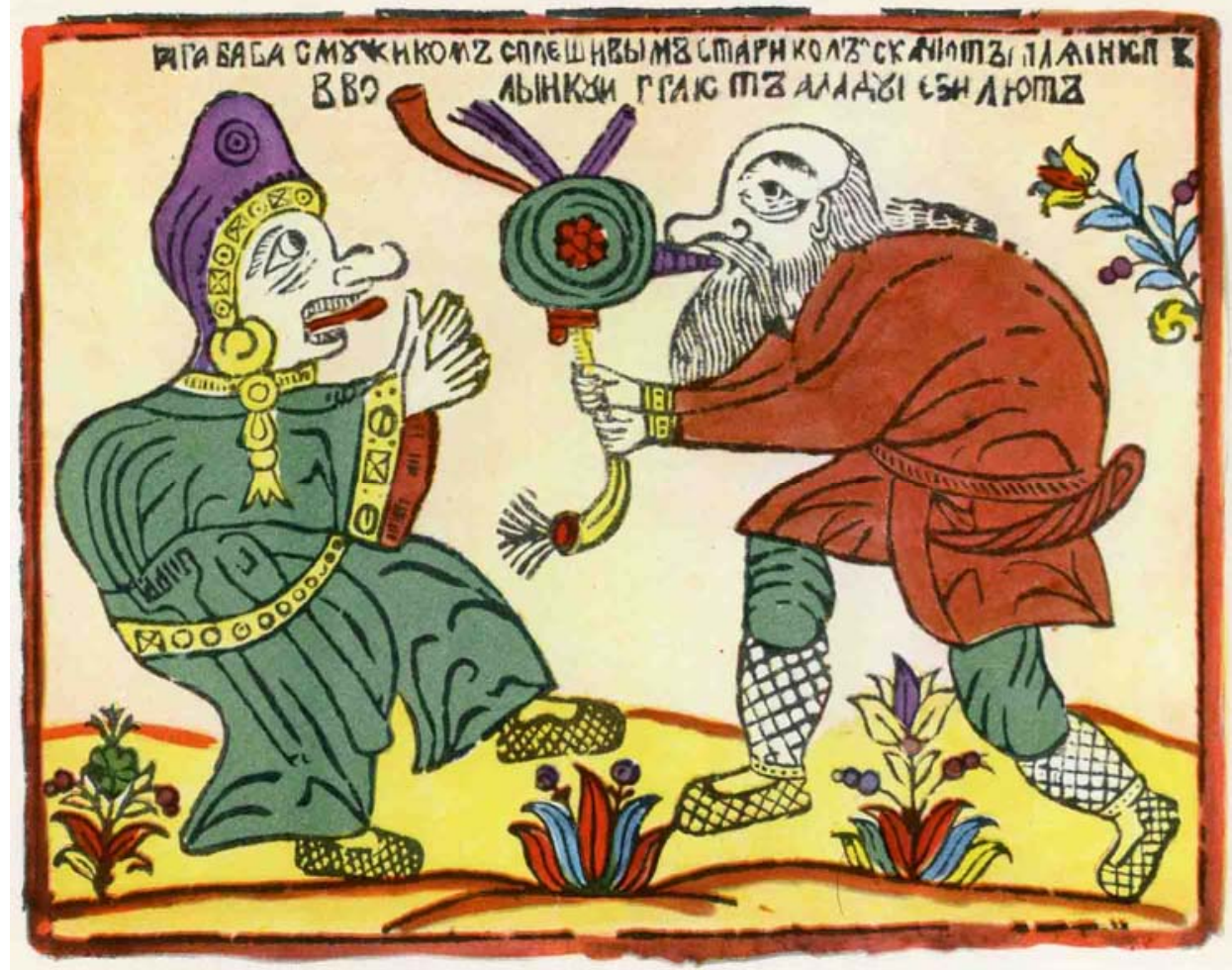

Iagá-Baba com mujique careca in Chánina, N. F. Skázka v tvórtchestve rússkikh khudójnikov (O conto popular na obra de pintores russos), p. 53. 
Nas telas de Víktor Mikháilovich Vasnetsóv (1848 - 1926), tem-se:

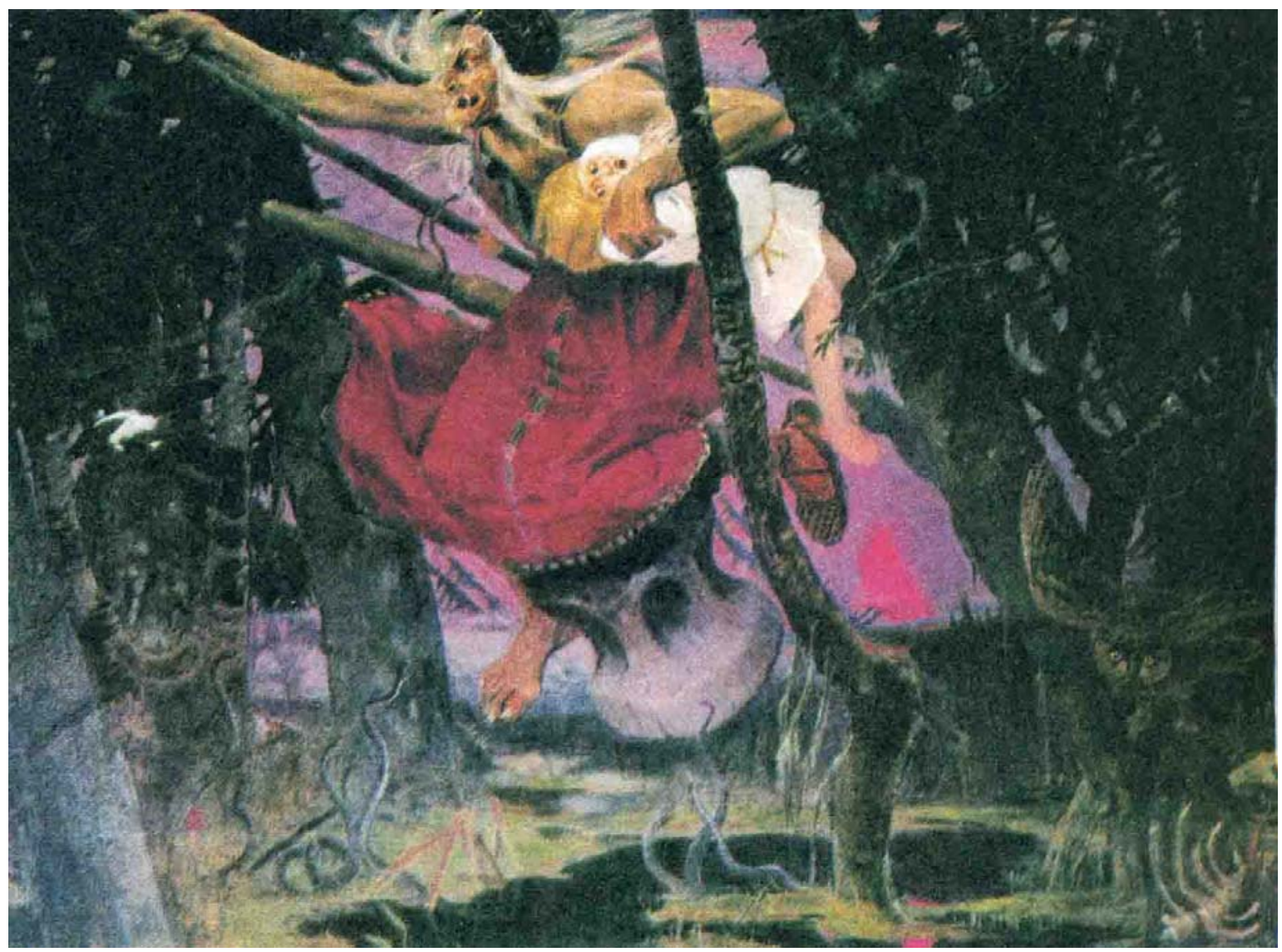

In Ussatchióv, A. (org.). Bolcháia kníga Báby-Iaguí (O grande livro da BabaIagá), p. 226. 
Nas aquarelas de Elena Dmitriévna Poliénova (1850-1898),

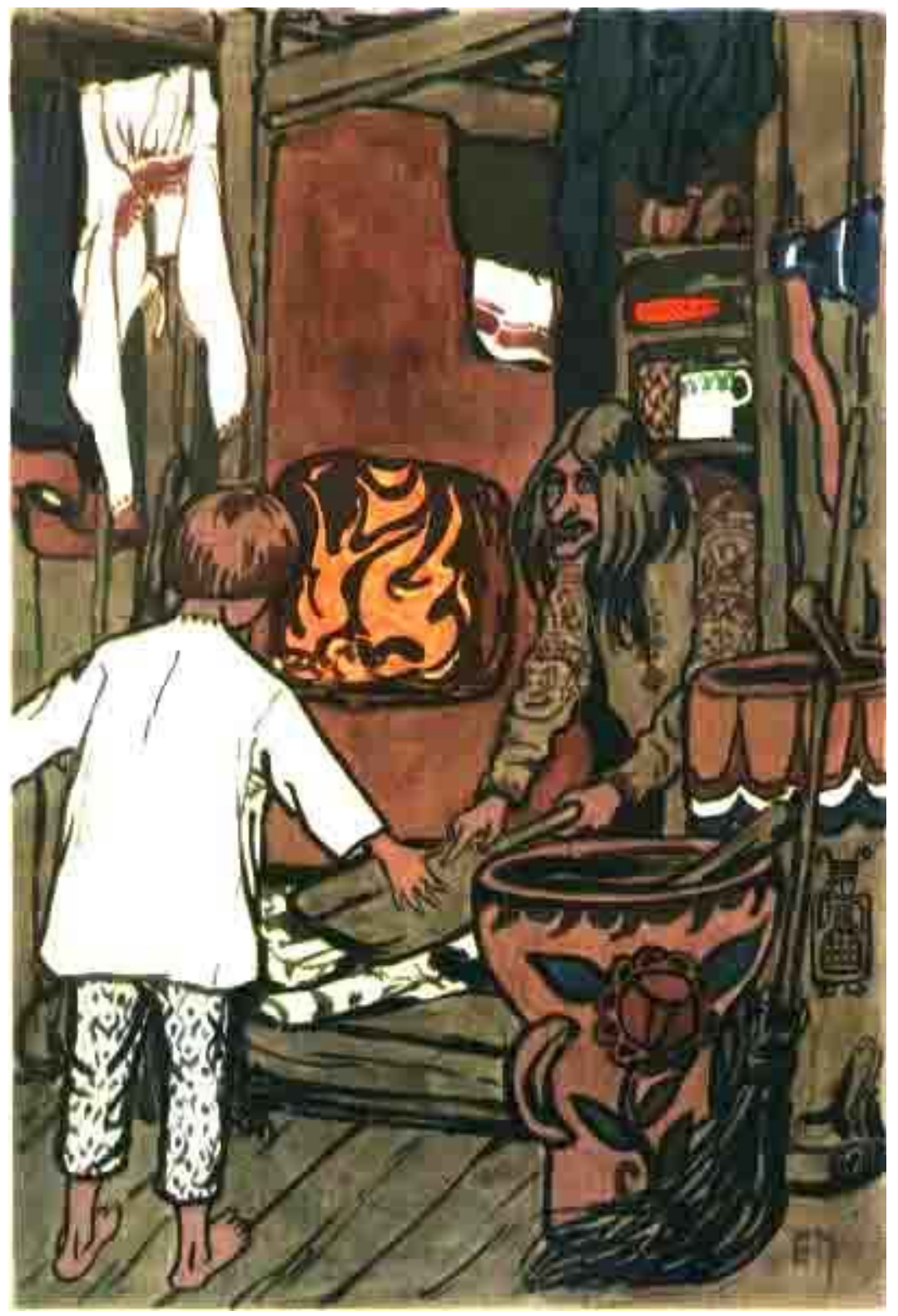

Cena do conto Sýnko-Filípko. Contado e ilustrado por E. D. Poliénova in Chánina, N. F. op. cit., p. 83. 
Nas ilustrações de Ivan Iákovlevich Bilíbin (1876-1942), há diversas versões:

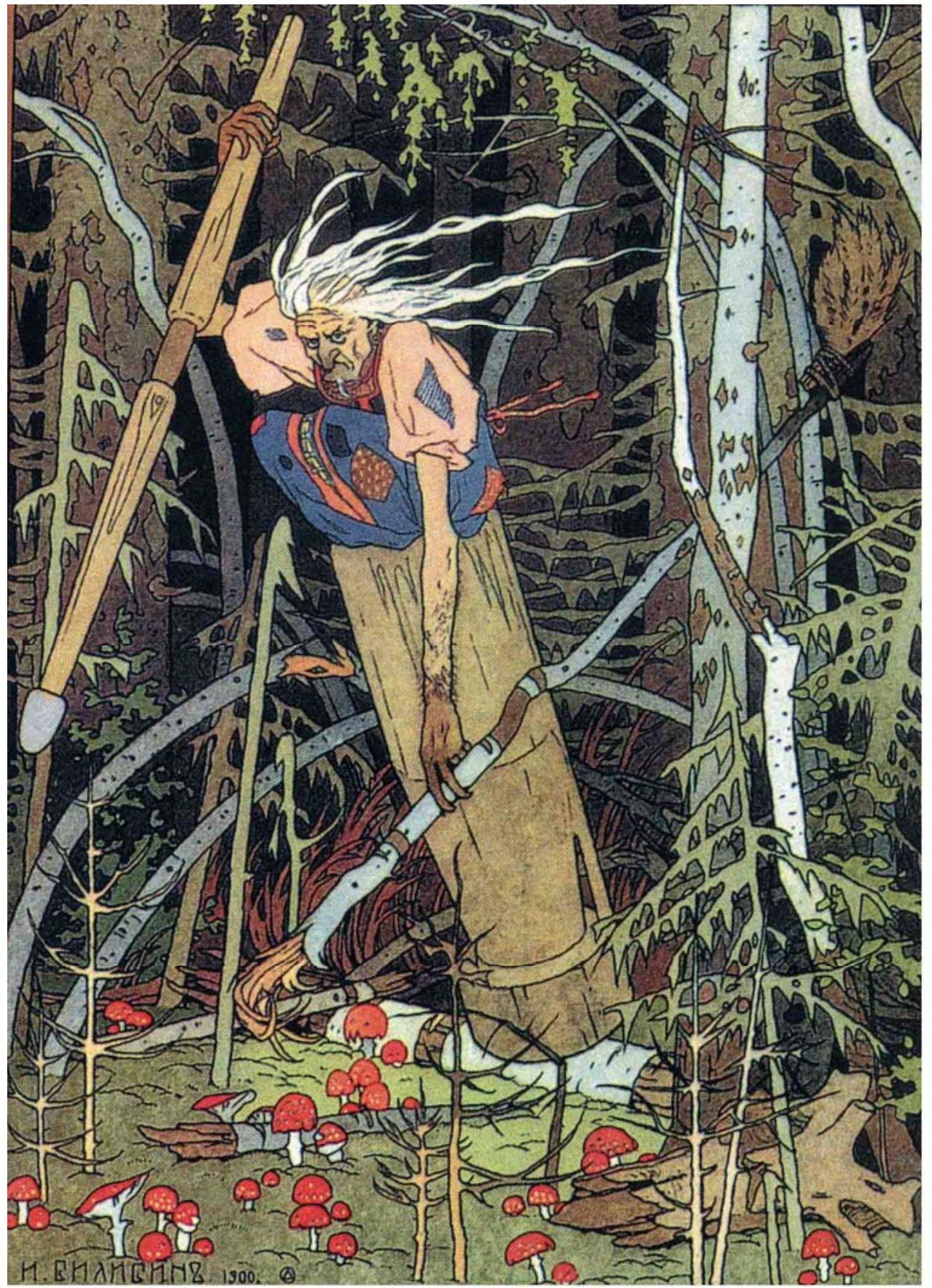

Ilustração para o conto Vassilíssa, a bela, 1900 in Afanássiev, A. N. Mifológuia driévnei Russi (Poetítcheskie vozzriéniia slavián na priródu) Mitologia da Rússia antiga. (Concepções poéticas dos eslavos sobre a natureza), p. 97. 


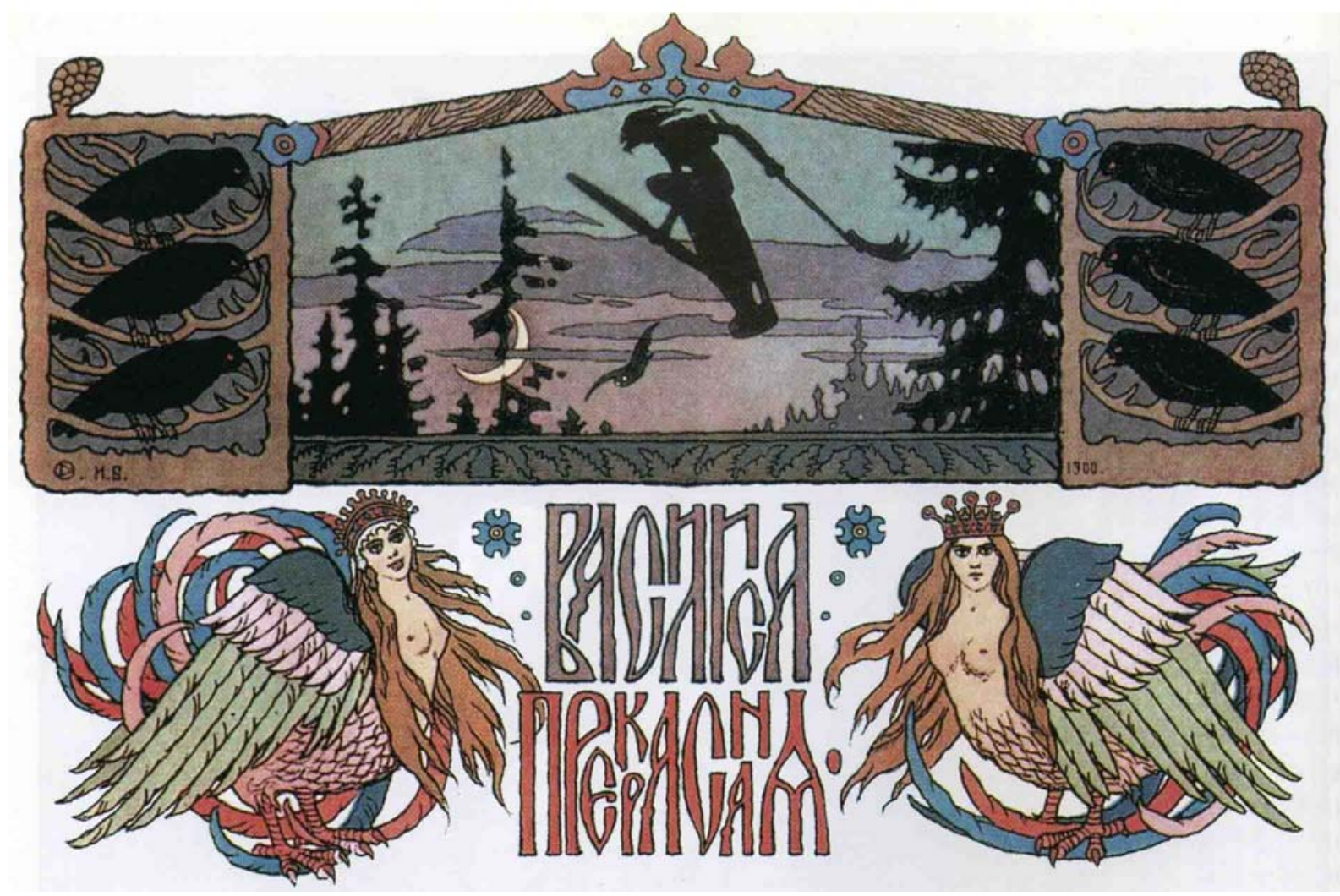

Baba-Iagá, Sírin e Alkonóst, vinheta para o conto Vassilíssa, a bela, 1900. Idem, p. 66.

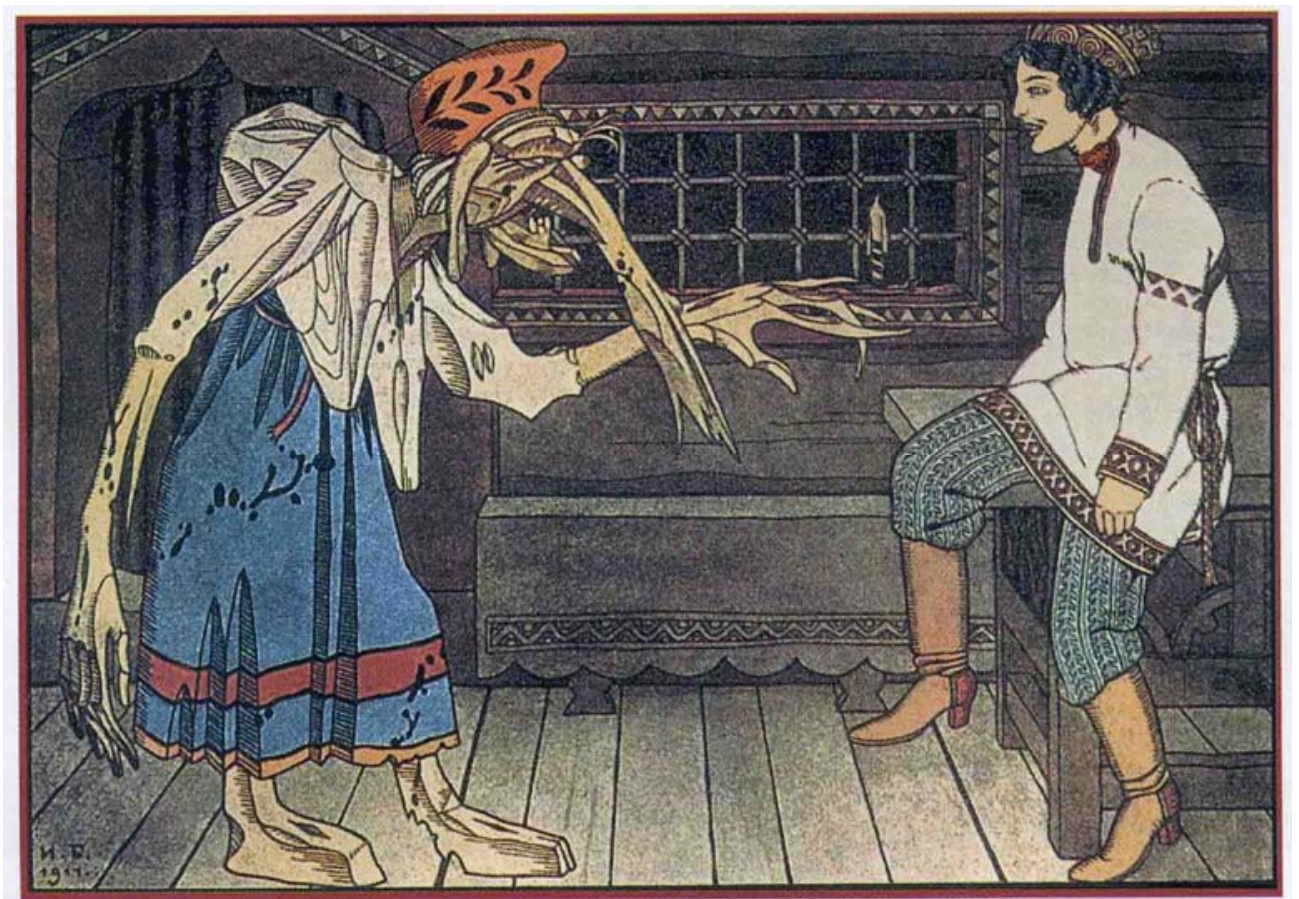

E com a alma alegre, ele se despediu da Iagá. Ilustração para o "Conto sobre as três donzelas tsarevnas e sobre Ivachko, o filho do pope”, de A. S. Roslávlev, 1911. Ibidem. 


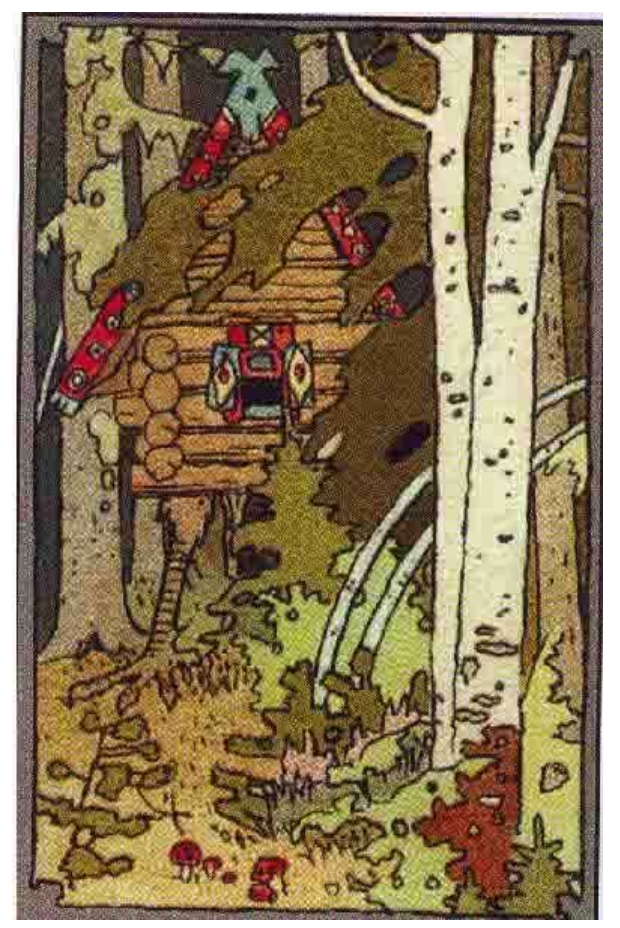

Detalhe da capa da série Contos populares, 1901. In Verijnikova, T. (org.). Ivan Bilíbin, p. 43.

Ainda nas artes plásticas, o pálekh também serviu como meio de representar a Iagá.

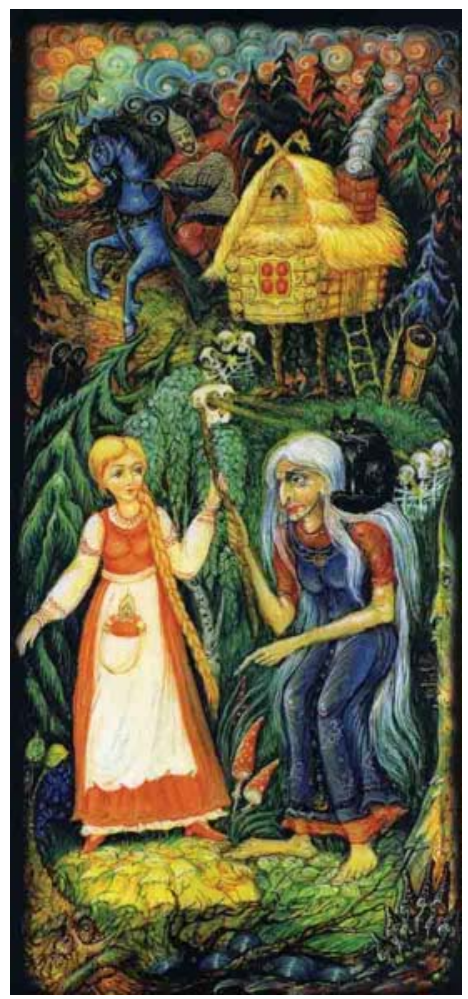

In Afanássiev, A. N. Contes populaires russes en peintures sur laque..., p. 81. 


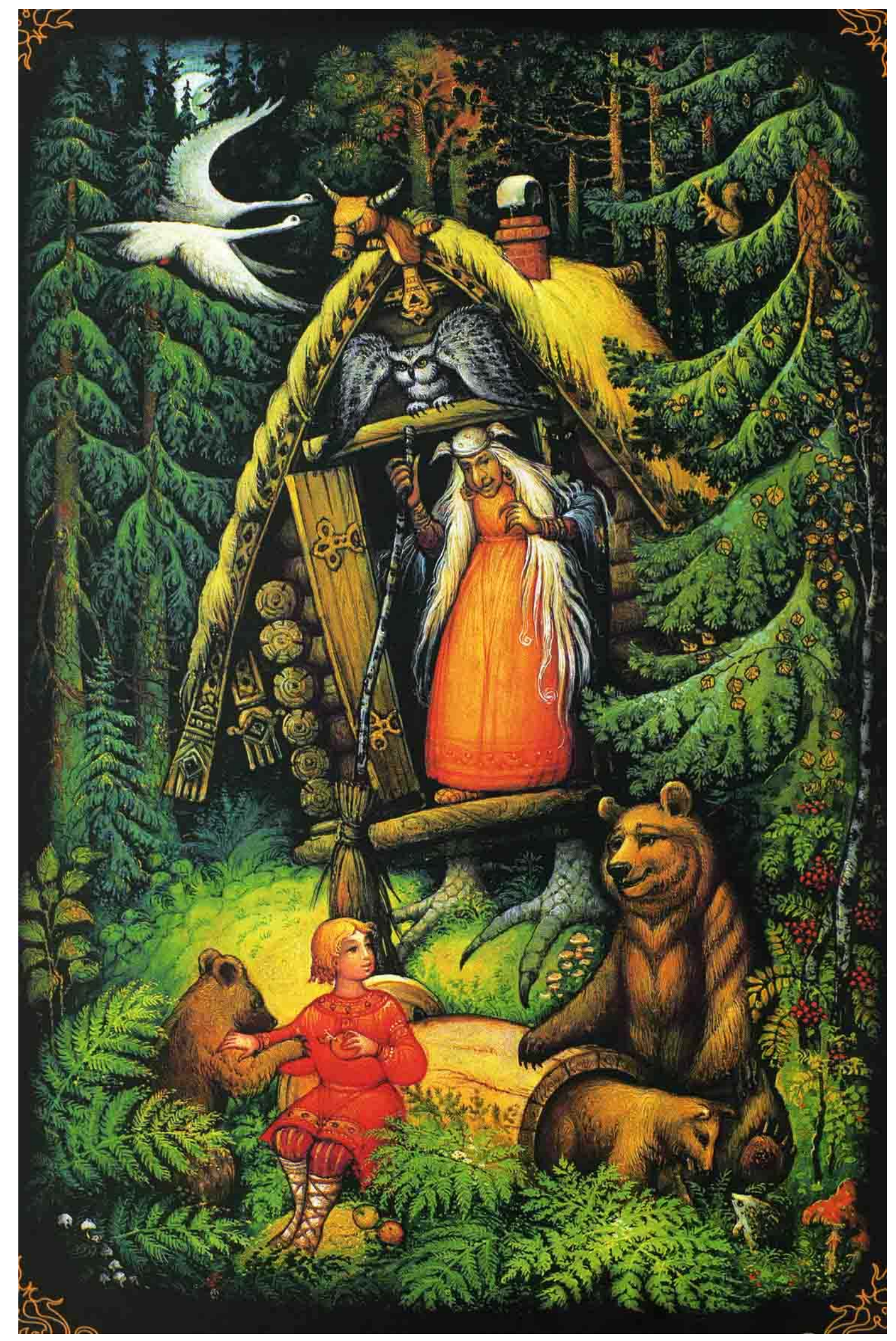

Idem, p. 75. 
Em concepções atuais, a Baba-Iagá foi assim ilustrada:

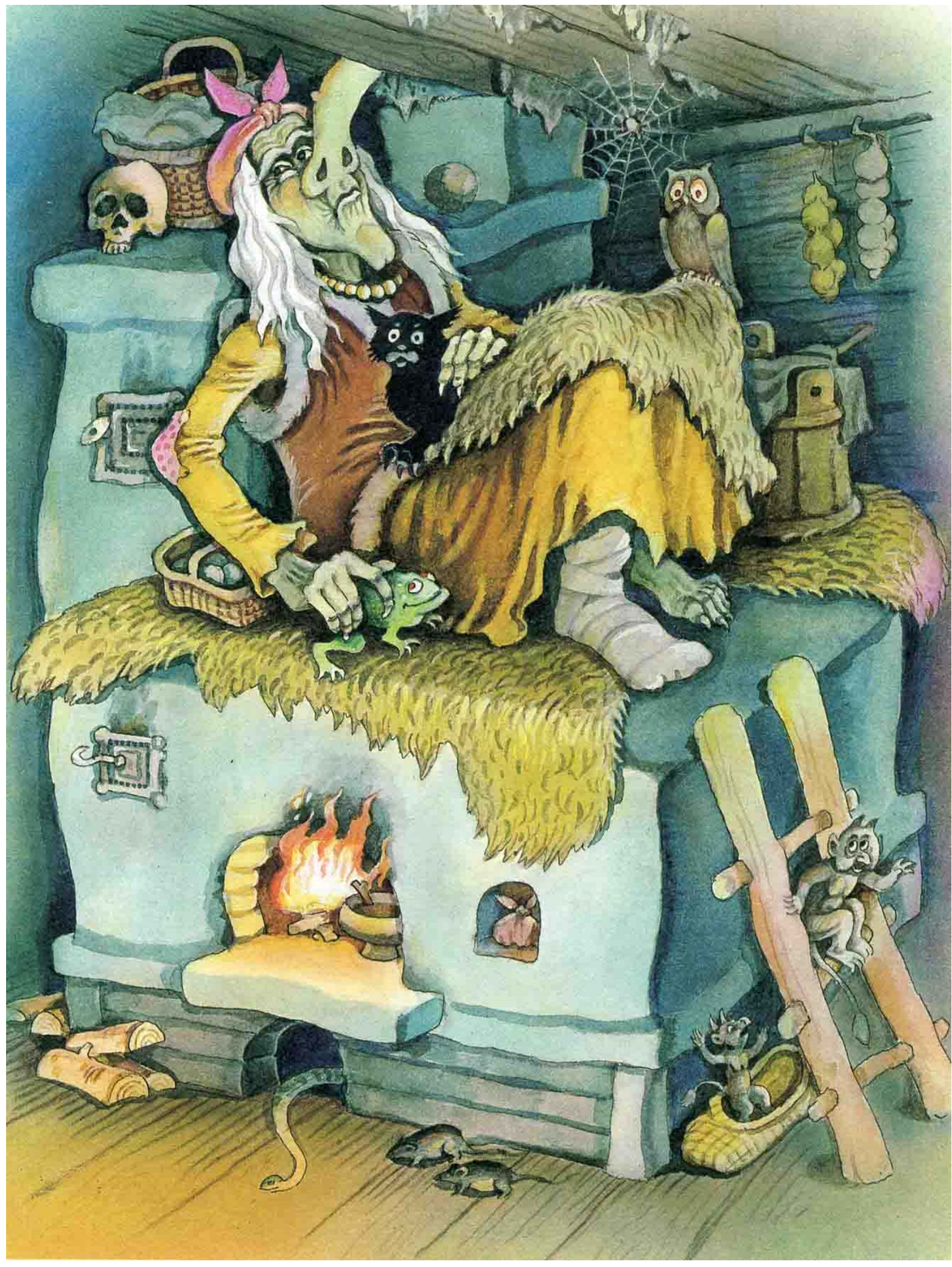

In Ussatchióv, A. (org.). op.cit., p. 9. 


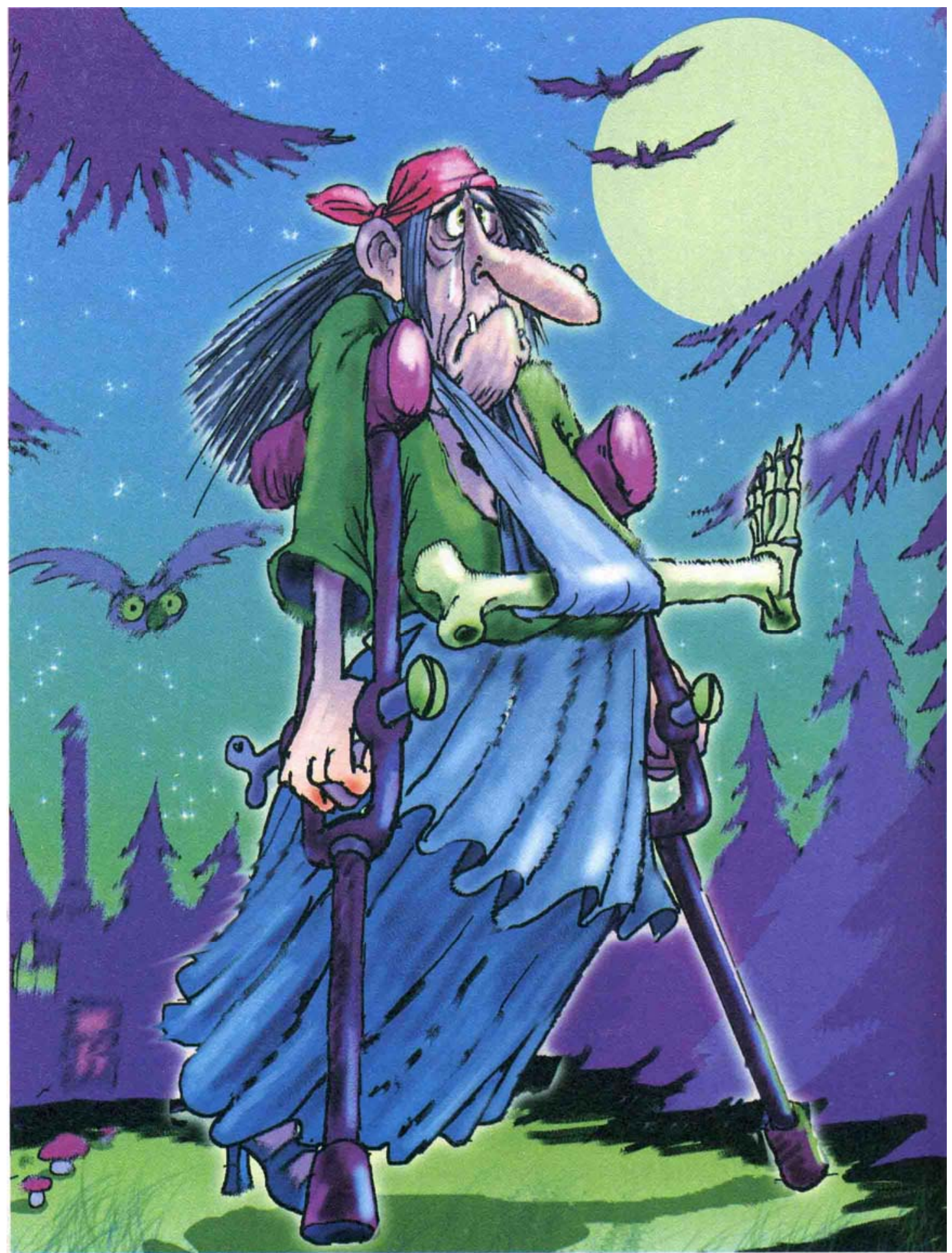

Idem, p. 152. 


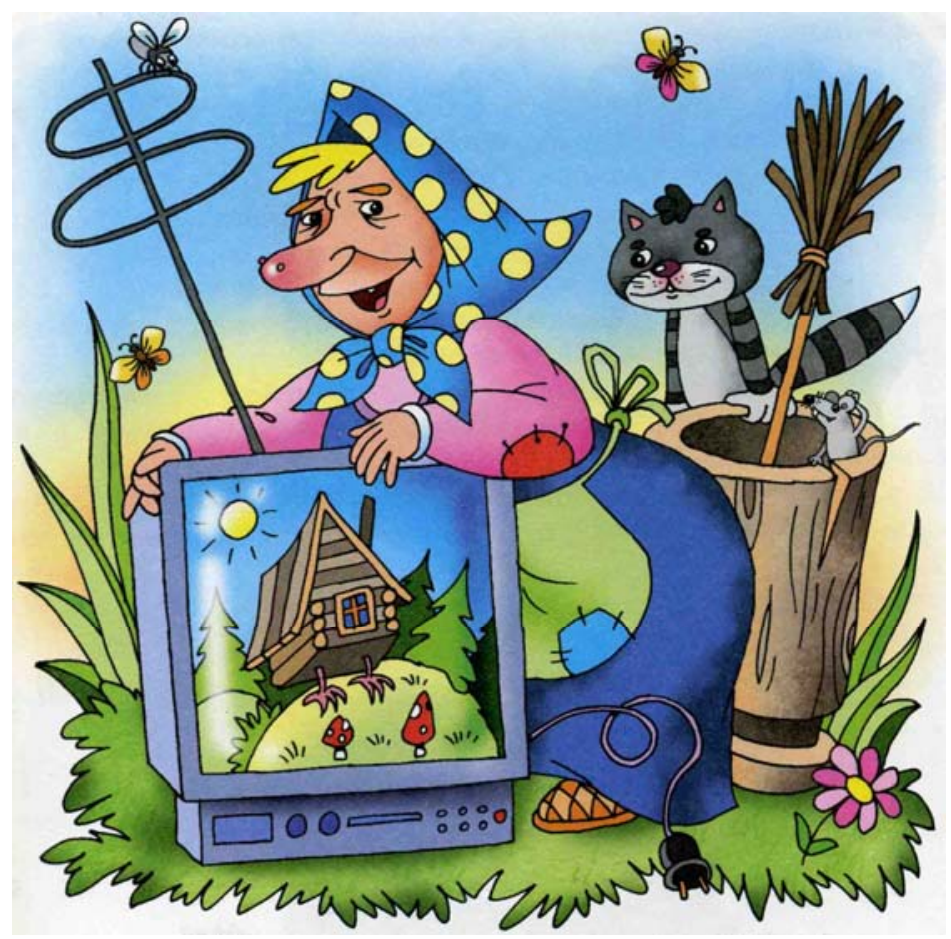

Idem, p. 71.

Sobre a isbazinha da Baba-Iagá, tem-se ainda:

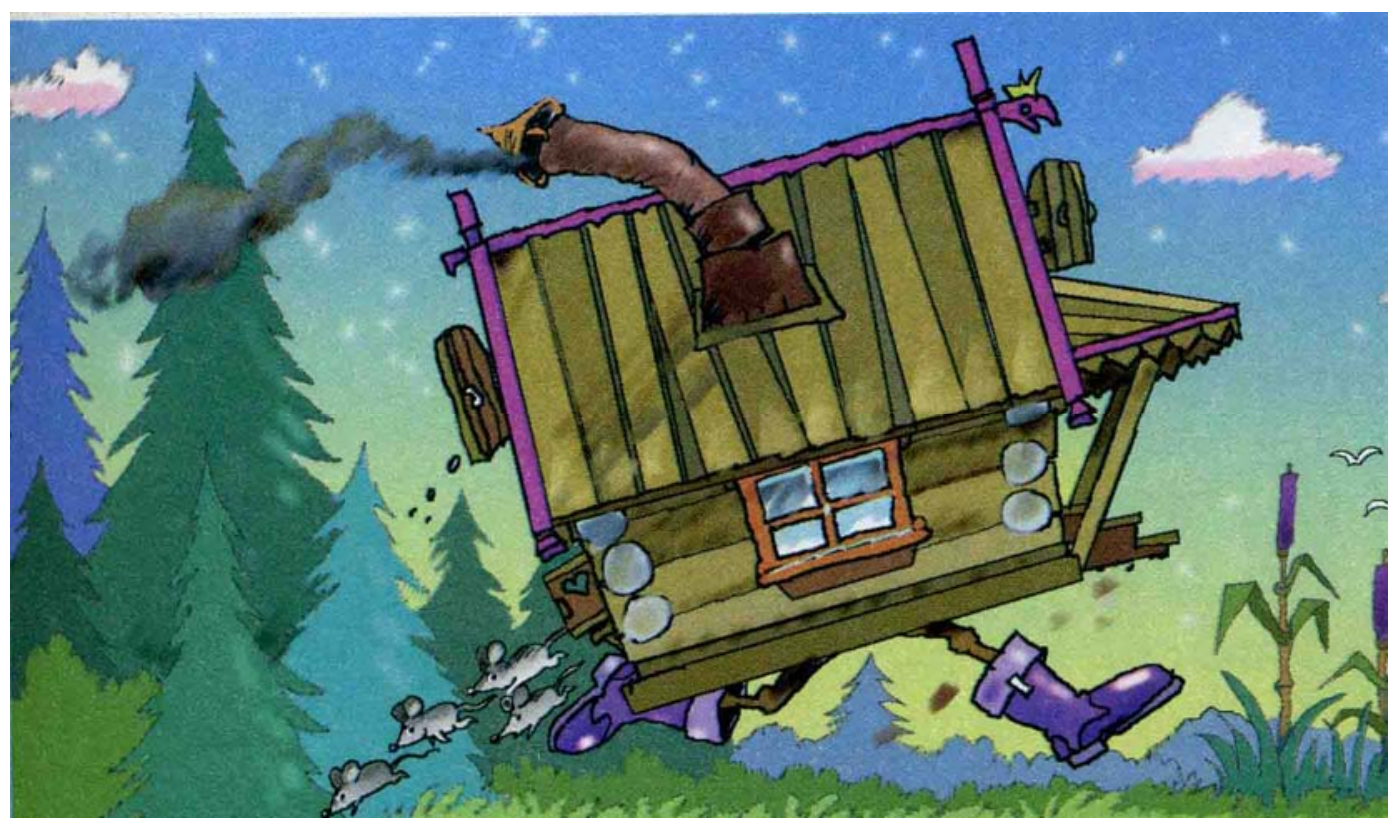

Idem, 157. 
A produção de filmes baseados em contos populares (fílmy-skázki) foi muito intensa durante a época soviética. A grande maioria dessas filmagens ocorreu sob a direção de Aleksandr Roe (1906-1973). O personagem Baba-Iagá foi interpretado por célebres atores como Gueórgui Mílliar (1903-1993), que esteve nesse papel nos filmes Vassilíssa, a bela (1939), Morósko (1964), Chifres de ouro (Zolotýe roga, 1972). Além disso, interpretou também Koschiéi, o imortal, o diabo e diversos outros personagens do conto popular. Entre outros atores e atrizes que desempenharam o papel estão Tatiana Ivánova Piéltser (1904-1992), em Lá, nos caminhos desconhecidos (Tam, na neviédomykh dorójkakh, 1982); Vera Altáiskaia (1919-1978) em Fogo, água e cornetas de cobre (Ogón, vodá i miéednyi trúby, 1968); Valentina Kossobútskaia (1947- ) em Aventuras de ano novo de Macha e de Vitia (Novogódnie prikliutchiéniia Máchi i Víti, 1975); Aleksándr Liénkov (1943- ) em A ilha do general enferrujado (Óstrov Rjávogo generala, 1988).

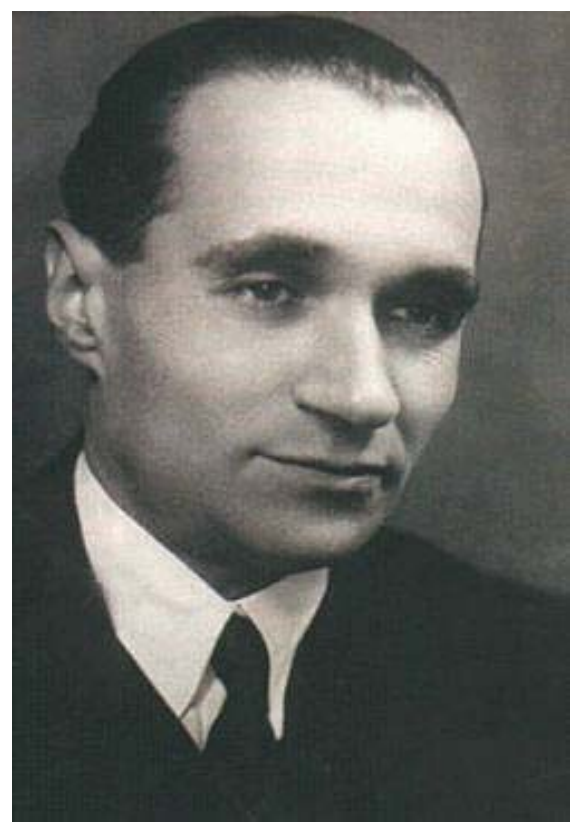

O ator Gueórgui Mílliar. 


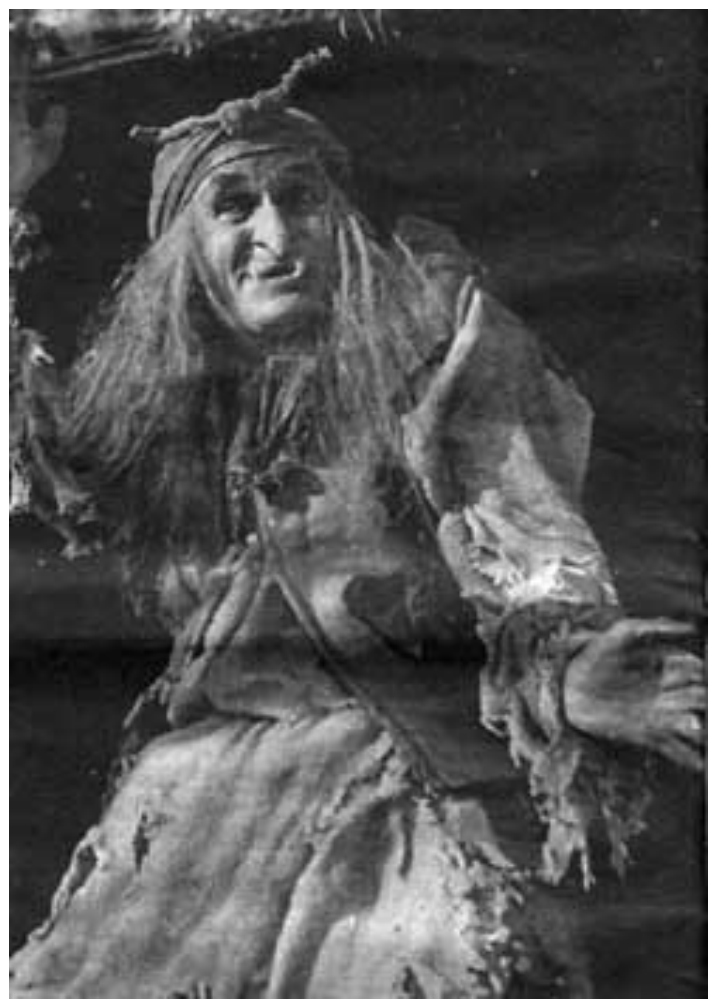

Gueórgui Mílliar no papel de Baba-Iagá em Vassilíssa, a bela (1939).
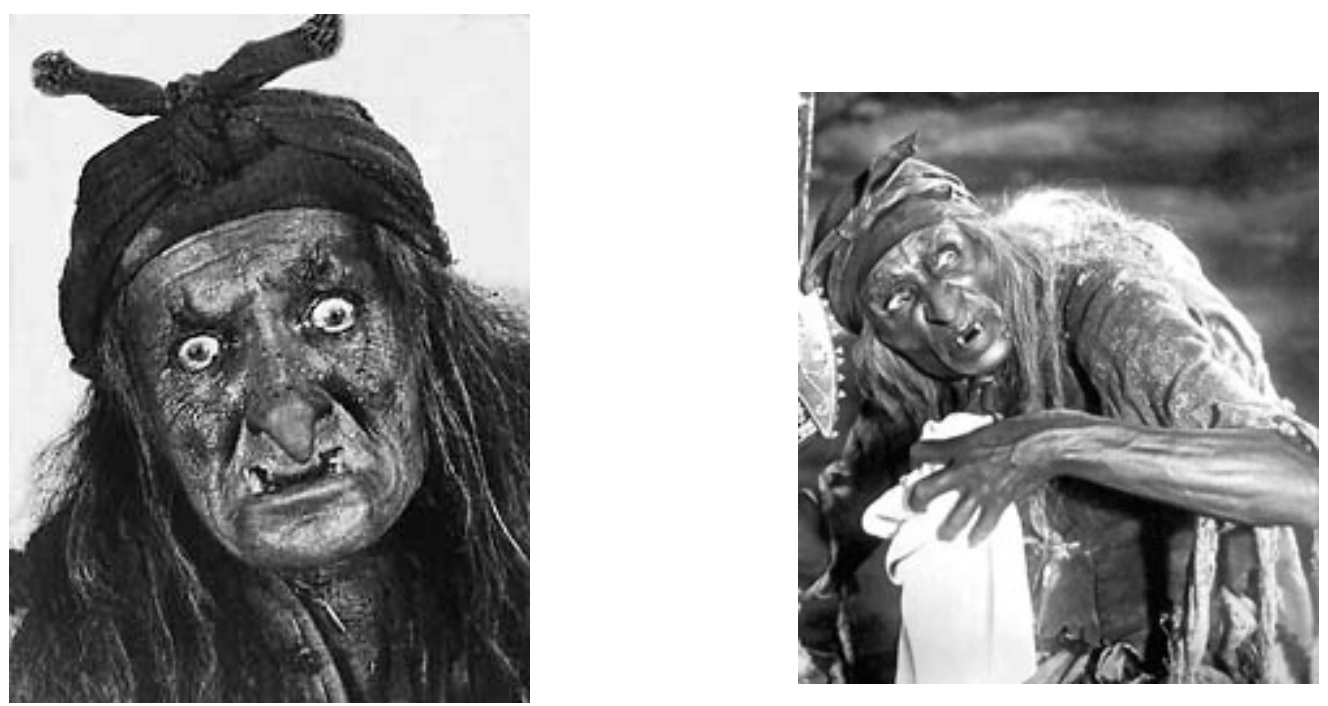

O ator no papel de Iagá. ${ }^{3}$

Na área da música e da dança, é inúmera a quantidade de obras com temas populares. Especificamente relacionadas à Iagá, citamos: Aleksándr Dargomýjskii (1813-1869) com Baba-Iagá (trabalho orquestral, 1862) e Modiést Mússorgski com o

\footnotetext{
${ }^{3}$ Imagens disponíveis em <http://www.peoples.ru/art/cinema/actor/millar/photo.html>
} 
episódio “A isbazinha sobre pernas de galinha (Baba-Iagá)”, presente na suíte para piano Quadros de uma exposição (1874).

Na área de animações, citamos a muito divertida Baba-Iagá contra (Baba-Iagá prótiv, 1980), de Vladímir Piékar, na qual ela e outros personagens do conto popular como a isbazinha, Koschiéi, o imortal, Zmei Gorýnytch se unem para destruir Micha, o ursinho símbolo das Olimpíadas de 1980 que ocorreram em Moscou. Alguns episódios podem ser vistos em http://www.youtube.com/watch?v=Upe6TZwgYBo

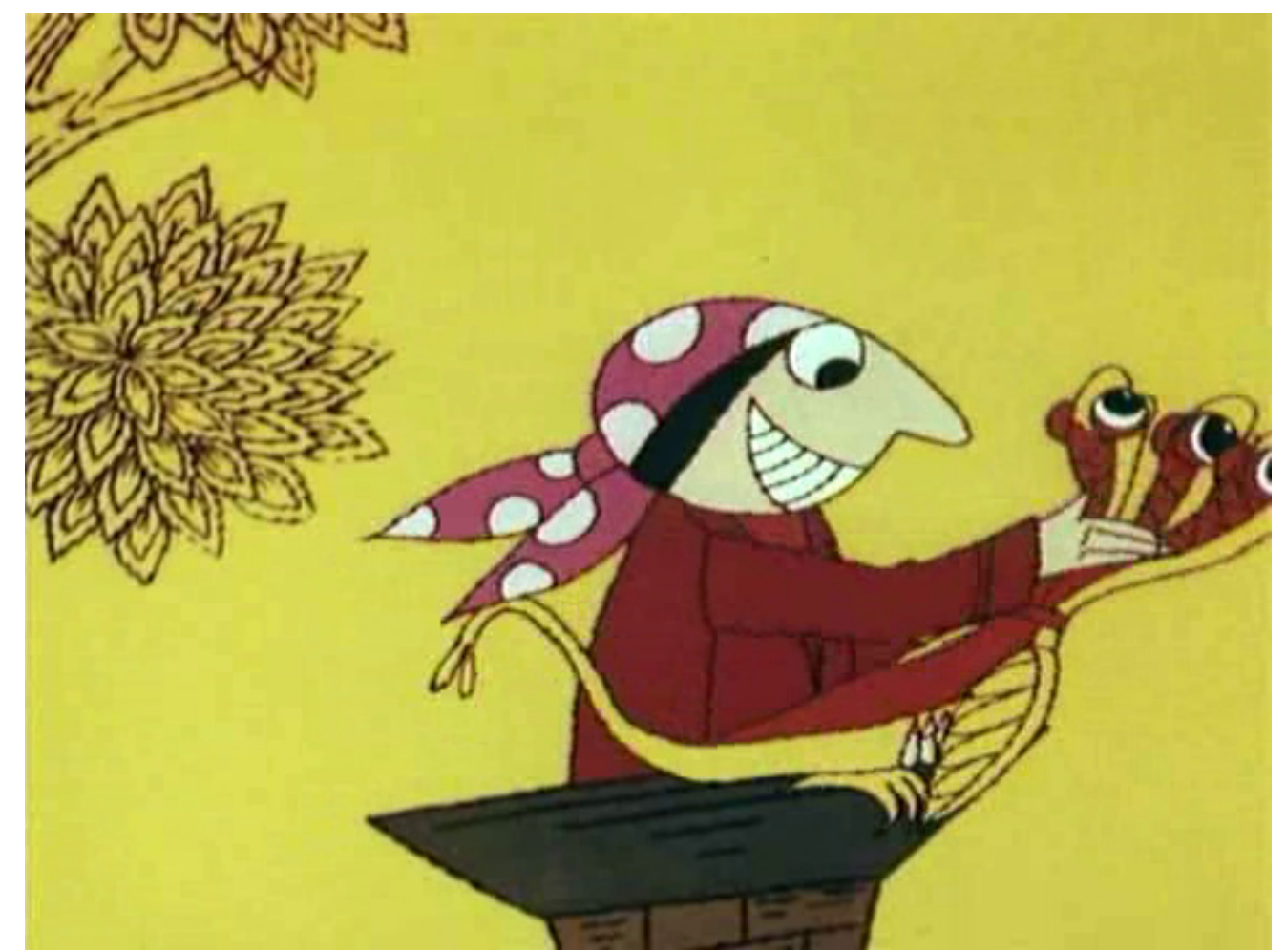

E como resultado da globalização, a Baba-Iagá foi parar em terras americanas onde participa da animação Emily e a Baba-Iagá, uma história com ares de conto infantil recheada de serras elétricas e personagens caracterizados ao estilo de aliens.

Vale citar ainda que atualmente os jogos de Role-Playing Game (RPG) são uma outra forma de divulgação mundial do personagem. Em quadrinhos e RPGs do personagem americano Hellboy, a Iagá surge repleta de outras influências, liderando até mesmo grupos de vampiros. 